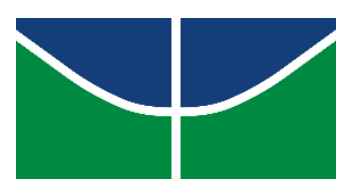

UNIVERSIDADE DE BRASÍLIA - UnB

INSTITUTO DE LETRAS - IL

DEPARTAMENTO DE LÍNGUAS ESTRANGEIRAS E TRADUÇÃO - LET PROGRAMA DE PÓS-GRADUAÇÃO EM ESTUDOS DE TRADUÇÃO POSTRAD

TRANSGRESSÃO E TRADUÇÃO: O ELEMENTO TRANSGRESSIVO NO TEXTO LITERÁRIO E O CASO DE CHUCK PALAHNIUK

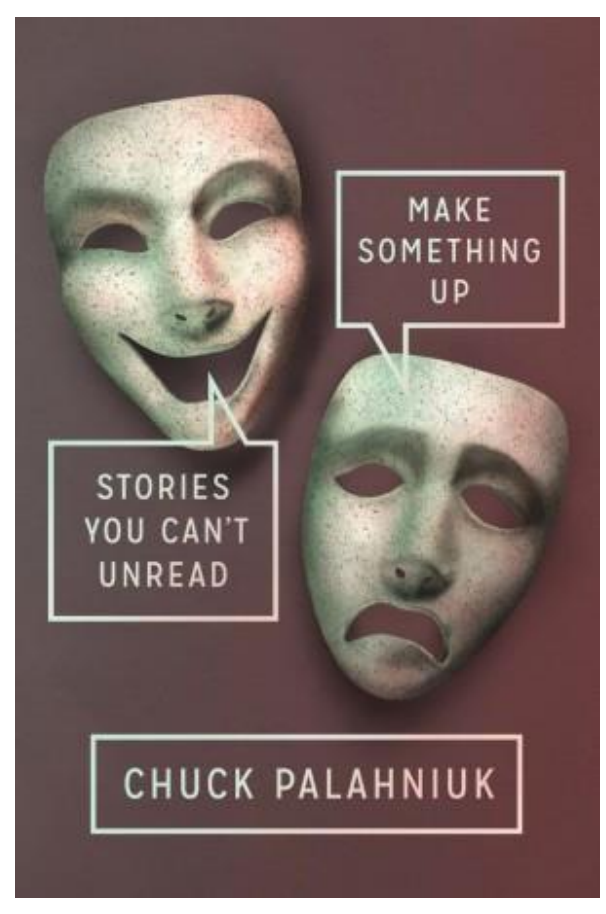

LORENA MELO RABELO

Brasília

Março/2017 


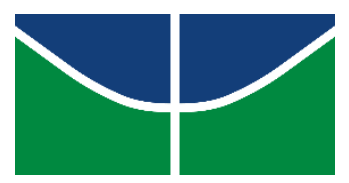

UNIVERSIDADE DE BRASÍLIA - UnB

INSTITUTO DE LETRAS - IL

DEPARTAMENTO DE LÍNGUAS ESTRANGEIRAS E TRADUÇÃO - LET

PROGRAMA DE PÓS-GRADUAÇÃO EM ESTUDOS DA TRADUÇÃO - POSTRAD

TRANSGRESSÃO E TRADUÇÃO: O ELEMENTO TRANSGRESSIVO NO TEXTO LITERÁRIO E O CASO DE CHUCK PALAHNIUK

LORENA MELO RABELO

Brasília

Março, 2017 
UNIVERSIDADE DE BRASÍLIA - UnB

INSTITUTO DE LETRAS - IL

DEPARTAMENTO DE LÍNGUAS ESTRANGEIRAS E TRADUÇÃO - LET

PROGRAMA DE PÓS-GRADUAÇÃO EM ESTUDOS DA TRADUÇÃO - POSTRAD

TRANSGRESSÃO E TRADUÇÃO: O ELEMENTO TRANSGRESSIVO NO TEXTO LITERÁRIO E O CASO DE CHUCK PALAHNIUK

\section{LORENA MELO RABELO}

ORIENTADOR: PROF. DR. JÚLIO CÉSAR NEVES MONTEIRO

DISSERTAÇÃO DE MESTRADO EM ESTUDOS DA TRADUÇÃO

Brasília

Março, 2017 
UNIVERSIDADE DE BRASÍLIA - UnB

INSTITUTO DE LETRAS - IL

DEPARTAMENTO DE LÍNGUAS ESTRANGEIRAS E TRADUÇÃO - LET

PROGRAMA DE PÓS-GRADUAÇÃO EM ESTUDOS DA TRADUÇÃO - POSTRAD

\title{
TRANSGRESSÃO E TRADUÇÃO: O ELEMENTO TRANSGRESSIVO NO TEXTO \\ LITERÁRIO E O CASO DE CHUCK PALAHNIUK
}

LORENA MELO RABELO

\begin{abstract}
DISSERTAÇÃO DE MESTRADO SUBMETIDA AO PROGRAMA DE PÓS-GRADUAÇÃO EM ESTUDOS DA TRADUÇÃO, COMO PARTE DOS REQUISITOS NECESSÁRIOS À OBTENÇÃO DO GRAU DE MESTRE EM ESTUDOS DA TRADUÇÃO.
\end{abstract}

BANCA EXAMINADORA:

Prof. Dr. Júlio César Neves Monteiro (POSTRAD/UnB)

(Orientador)

Prof. ${ }^{a}$ Dra. Alice Maria Araújo Ferreira (POSTRAD/UnB)

(Examinadora Interna)

Prof. ${ }^{a}$ Dra. Sinara de Oliveira Branco (POSLE/UFCG)

(Examinadora Externa)

Prof ${ }^{a}$. Dra. Germana Henriques Pereira de Sousa (POSTRAD/UnB )

(Suplente) 
Para mamis:

você é a melhor do mundo. $\bullet$ 


\section{AGRADECIMENTOS}

Agradeço, do fundo do meu coração capricorniano (que existe, sim, apesar do que dizem por aí), minha mãe, Cristina. Obrigada por ficar sempre do meu lado, me apoiar e defender, mesmo quando não concorda comigo, por ser minha amiga e companheira, por cuidar de mim e, principalmente, por aturar meu mau humor e ansiedade e me ajudar a pôr a cabeça no lugar quando as coisas complicam (e como complicaram, hein?!). Por tudo, te amo!

Gratidão eterna também ao meu orientador, Júlio Monteiro, que foi minha luz no fim do túnel e aceitou me orientar, mesmo faltando tão pouco tempo e tanto trabalho. Obrigada demais por ser tão paciente, compreensivo e incrível o tempo todo. Eu o admiro muito e desejo tudo de mais bonito nessa nova jornada.

Gratidão especial, com chuva de glitter, luz estroboscópica, cascatas de catuaba e unicórnios saltitantes, às migas Lili e Adriano: vocês seguraram minha barra esse ano de um jeito que não fazem ideia. Na alegria e na tristeza, na saúde e na doença, na pobreza e, bem, na riqueza o dia que vier a gente descobre, tamo junte, amores

Às minhas parceiras do mestrado, Angelzinha (mozona $\bullet$ ), Brunilds e Pri: vocês sabem bem como foi, e obrigada demais por tudinho. Esse mestrado ter aproximado a gente foi, sem a menor dúvida, a melhor parte dele.

Às migas (e prima) que me aturaram esse último ano, entenderam meu sumiço e não desistiram de mim: cada momentinho que a gente passou junto, cada palavrinha de encorajamento que vocês me disseram, cada porrezinho que a gente tomou, pela sarração, problematização e por toda a alegria que vocês trazem para a minha vida: muitíssimo obrigada Aline, Alyne, Adílio, Lorran, Jana, Betinho e Natália, cêis são foda.

Aos meus meninos, Caio e João, por todo o apoio, carinho, paciência, palavras de conforto e incentivo, y otras cositas más:

À Catuaba Selvagem ${ }^{\circledR}$, rainha da porra toda, gratidão demais! Tinha hora que só a senhora mesmo pra dar conta, viu, salvou o rolê.

Gratidão aos professores Mark, Germana, Alessandra, Alice e Eclair, por toda a ajuda, incentivo e dicas, vocês foram parte da construção desse trabalho!

Agradeço, por fim, ao imprescindível apoio institucional da Coordenação de Aperfeiçoamento Pessoal de Ensino Superior (CAPES). 


\section{RESUMO}

A presente pesquisa aborda a Ficção Transgressiva, gênero ainda pouco estudado pela teoria e crítica literárias e menos ainda pelos Estudos de Tradução, mas que caracteriza um grande número de obras da literatura ocidental contemporânea. Pretendese analisar o elemento transgressivo no texto literário a partir dos princípios de transgressão apresentados por Michel Foucault em seu ensaio "Prefácio à transgressão" (2009), chegando enfim às mais recentes reflexões teóricas, que veem a transgressão como um elemento inerente ao exercício literário, uma versão moderna da sátira (com função de incentivar e operar mudanças sociais), caso de M. Keith Booker (1991) e Robin Mookerjee (2013). Para tal, traçamos um panorama histórico do surgimento e amadurecimento da ficção transgressiva na literatura norte-americana, polissistema literário com o qual escolhemos trabalhar, a fim de tentar compreender de que forma esse gênero chegou às mãos dos leitores brasileiros e por qual motivo tem sido cada vez mais traduzida para o português. Em seguida, introduzimos o autor e a obra que selecionamos para a pesquisa: Chuck Palahniuk, escritor transgressivo norte-americano, e sua primeira coletânea de contos Make something up: stories you can't unread (2015), que reúne um total de vinte e dois contos e uma novela, dentre os quais foram analisados e traduzidos "Knock-knock", "How Monkey got married, bought a house and found happiness in Orlando", “Zombies" e "Loser”. Tratam-se de textos sensíveis, vanguardistas e polêmicos também no que concerne o uso da língua e estrutura textual, que permitem uma grande variação de estilos, recursos linguísticos e literários, enredos, temas abordados, entre outros aspectos. A partir da tradução desses textos, tecemos comentários sobre como se dá a reescrita de textos transgressivos em português, de que forma ela pode se mostrar desafiadora para o tradutor e que estratégia de tradução desenvolvemos e aplicamos no processo tradutório.

Palavras-chave: Transgressão; Ficção Transgressiva; Tradução; Chuck Palahniuk. 


\begin{abstract}
This research study focuses on Transgressive Fiction, a genre seldom approached in literary criticism and theories, even more rarely so in Translation Studies, but one that accounts for a considerable number of works in contemporary Western literature. The transgressive element shall be herein analyzed according to the transgressive principles presented by Michel Foucault in his essay "A Preface to Transgression" (2009), finally covering some recent theoretical reflections that see transgression as an inherent element to the literary exercise - as a modern version of satire, it has the function of encouraging and operating social changes -, as do the works of M. Keith Booker (1991) and Robin Mookerjee (2013). In order to do so, we provide a historical overview regarding how transgressive fiction has come into being and grown in American literature, the literary polysystem we chose to work with, as a way of understanding how come Brazilian readers are now reading this gender and why it is being progressively more translated into Portuguese. The next step is to present the author and work of fiction chosen for the research: Chuck Palahniuk, American transgressive writer, and his first collection of short stories, Make something up: stories you can't unread (2015). It gathers together twentytwo short stories and a novella, among which we have analysed and translated "Knockknock", "How Monkey got married, bought a house and found happiness in Orlando", "Zombies" and "Loser. Those texts are also sensitive, innovative, and controversial regarding the language use and textual structure, which bring about a wide variety of styles, linguistic and literary resources, plots, themes, among other aspects. Finally, based on the translation and analysis of these texts, we have commented on how transgressive texts are rewritten in Portuguese, how they can present themselves as a challenge for translators and what we have developed and applied as translation strategies in the translation process.
\end{abstract}

Keywords: Transgression; Transgressive Fiction; Translation; Chuck Palahniuk. 


\section{SUMÁRIO}

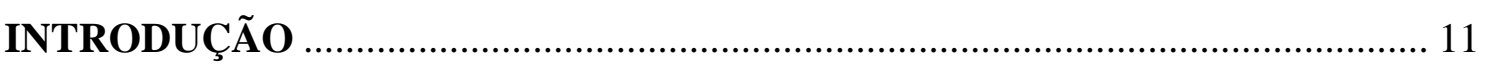

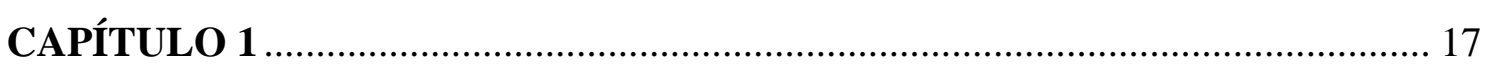

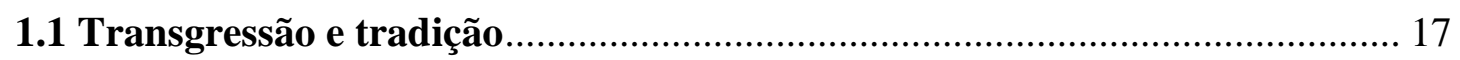

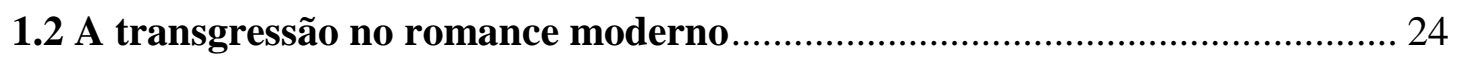

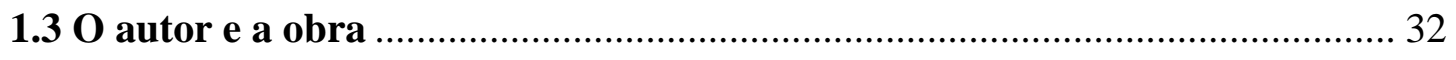

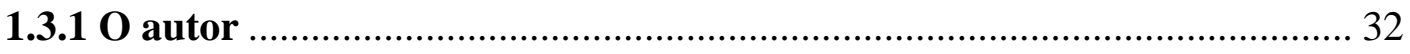

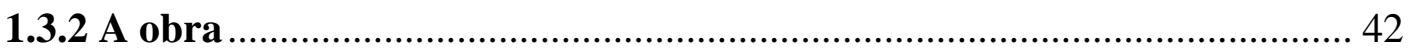

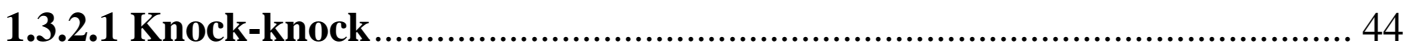

1.3.2.2 How Monkey got married, bought a house and found happiness in

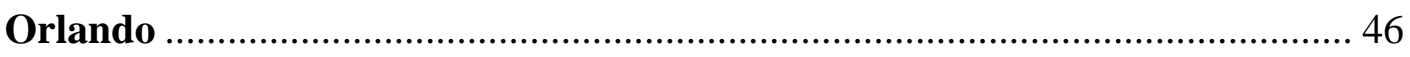

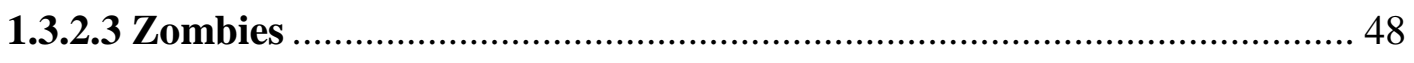

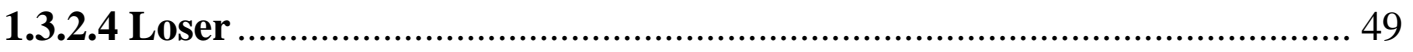

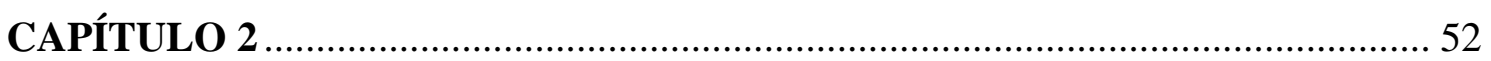

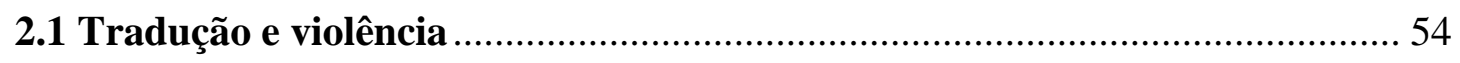

2.2 A fiç̧ão transgressiva no polissistema literário …………………………….... 55

2.3 Reflexões sobre os gêneros literários dos textos traduzidos.............................. 64

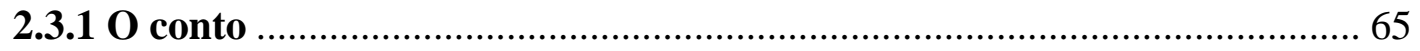

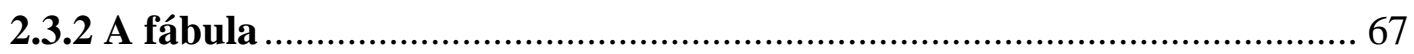

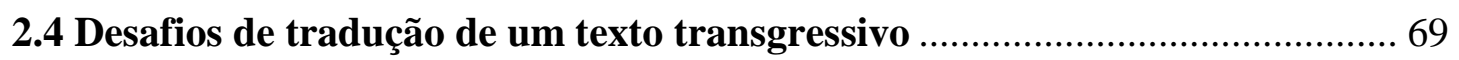

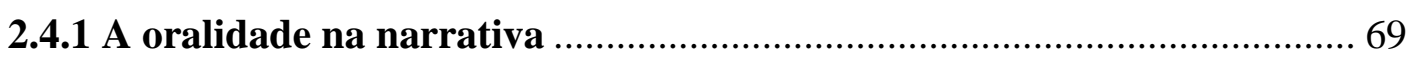

2.4.2 A tradução do humor ................................................................................ 72

2.4.3 Referências culturais: como lidar com elas?.............................................. 75

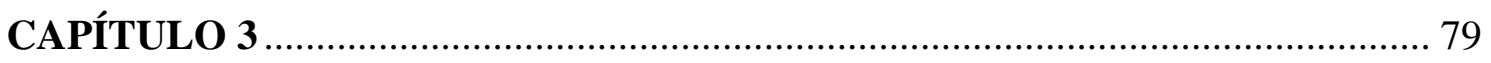

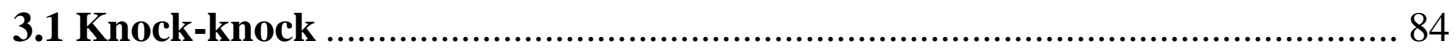

3.2 How Monkey got married, bought a house and found happiness in Orlando

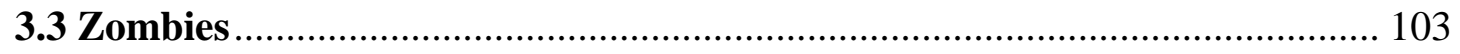

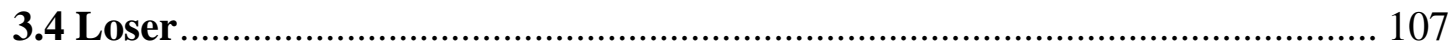

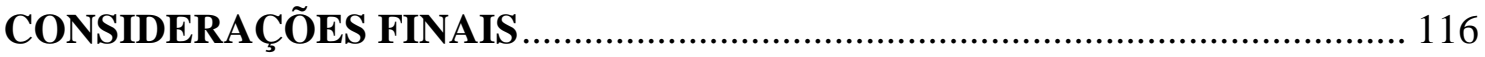

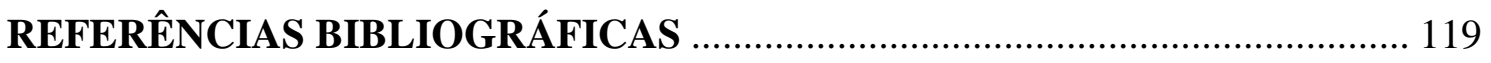

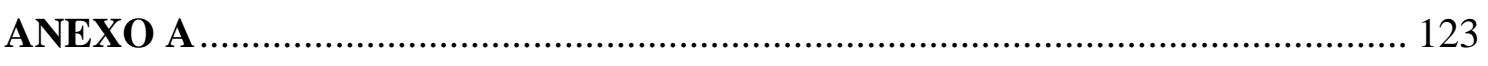

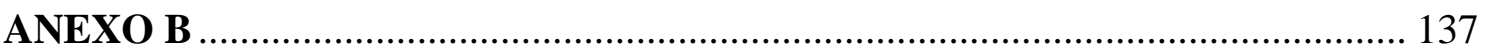


ANEXO C

153

ANEXO D

171 


\section{INTRODUÇÃO}

Compreendemos a transgressão na literatura como a transposição de barreiras e limites sociais, em um movimento ou ação isolada que contornam ou superam padrões e imposições de instituições de poder, seja com tema, linguagem ou qualquer outro recurso que o autor escolha empregar. Partindo dessa definição, não é preciso muito esforço para lembrar de obras com caráter transgressivo, ainda que não seja essa a principal intenção do texto. O próprio Dom Casmurro, de Machado de Assis, um dos textos mais icônicos da literatura brasileira, pode ser considerado transgressivo, uma vez que a personagem Capitu transgride com seu comportamento as expectativas sociais que se tinha de uma mulher no período do romance ${ }^{1}$.

Esse exemplo serve para mostrar que, diferente do que se pensa, a transgressão literária não é novidade, tampouco gênero exclusivo da literatura pós-moderna ou da "ficção transgressiva" norte-americana como é conhecida hoje em dia. É fácil supor tal coisa por conta do boom transgressivo que o mercado literário vivenciou desde o início dos anos 1990, porém a história da transgressão na literatura ocidental vem de muito mais longe. M. Keith Booker (1991) chega a traçar a transgressão até a antiguidade clássica, com a sátira greco-latina, que, por sua vez, é transgressiva ao criticar, de forma exagerada e carnavalesca, práticas sociais e instituições de poder.

Tendo isso em mente, ao longo da presente pesquisa, pretendemos apresentar a transgressão na literatura e sua evolução através das décadas em obras de ficção, a partir da segunda metade do século XX, até chegar à ficção transgressiva da atualidade. É nesse contexto de transgressão na literatura que se insere o autor que escolhemos para traduzir: Chuck Palahniuk, escritor norte-americano mais conhecido por seu romance de estreia, Fight club (1996), e um dos maiores nomes da ficção transgressiva contemporânea. Enfatizamos que, apesar de a transgressão ser elemento do texto literário que ultrapassa barreiras geográficas, o que chamamos aqui de "ficção transgressiva" se refere necessariamente à literatura em língua inglesa do gênero, principalmente a norteamericana, com influências de caráter transgressivo de outras literaturas ocidentais, em especial a literatura francesa, com Rabelais, Bataille e Marquês de Sade.

\footnotetext{
${ }^{1}$ Consoelo Costa Soares aborda a transgressão de Capitu mais profundamente em seu artigo O transgredir da personagem Capitu em Dom Casmurro: manifestações de um ser fictício. Disponível em: http://www.unemat.br/revistas/fronteiradigital/docs/artigos/n2_2010/fronteira_digital_n2_2010_art_3.pdf. Acesso em dezembro de 2016.
} 
Nosso objetivo é tentar compreender a relação entre transgressão e tradução, aventando a hipótese de que o exercício de tradução possa ser um ato de transgressão, e, para que tal possibilidade seja posta à prova, sendo, então, refutada ou comprovada, fazse necessária a prática da tradução. Desse modo, foram selecionados e traduzidos quatro contos da obra Make something up: stories you can't unread (2015), de Chuck Palahniuk. São eles: "Knock-knock", "How Monkey got married, bought a house and found happiness in Orlando", "Zombies" e "Loser". Os textos são dinâmicos e muito variados, tanto em termos de tema quanto de estrutura, e apresentam desafios de tradução interessantes, bem como oportunidades de refletir sobre o ato tradutório. Pretende-se desenvolver um projeto de tradução que atenda às exigências desse texto, deixando transparecer seu local de fala, sua cultura, sociedade e as críticas que o autor faz sobre elas, de forma a incentivar o leitor a refletir sobre sua própria cultura e sociedade a partir do olhar crítico sobre as do outro. O texto transgressivo é sempre muito preocupado com o efeito que causa (como veremos mais adiante), seja ele um efeito de choque, de ultraje, de estranhamento, de reflexão, de emoção ou de riso, e, por esse motivo, durante todo o processo, adotamos uma postura de tradução que priorizasse a reprodução de tais efeitos. É importante para nós que o leitor da tradução tenha a reação pretendida pelo texto de partida, e, para tal, é importante que ele soe natural e confortável de se ler na língua alvo.

Para chegar a tal proposta de tradução, vamos, em um primeiro momento, estudar a ficção transgressiva, compreender suas características, analisar o elemento transgressivo no texto literário e o poder de transgressão que a literatura pode ter. É, nesse momento, que traçaremos um panorama histórico, onde, como foi dito acima, pretendemos associar o surgimento e posterior crescimento de obras de cunho transgressivo aos acontecimentos político-sociais da segunda metade do século XX, constando do fim da II Guerra Mundial, considerando que a literatura é, entre outras coisas, um retrato escrito da sociedade.

Acrescenta-se a isso o estudo da tradução desse tipo de texto, momento em que buscamos perceber como se dá a tradução de obras com estruturas textuais e linguísticas transgressivas e temas tabus. Sabendo que a ficção transgressiva pode ter função satírica e agir como agente social, chamando a atenção para problemas e mazelas da comunidade e tentando fazer com que seu leitor desenvolva o pensamento crítico sobre assuntos que precisam ser, mas que raramente são, discutidos, pretendemos analisar o poder transgressivo dessas obras dentro da cultura de chegada. 
Procuramos, ainda, identificar a posição desse gênero no polissistema literário de partida, bem como descobrir de que forma e em qual posição ele se insere no polissistema literário brasileiro. Será analisado o que motiva a tradução desse tipo de ficção, sabendo, de antemão, que ficção como a transgressiva norte-americana não é produzida no Brasil, chegando aos leitores brasileiros do gênero através da tradução.

Ao fim do processo tradutório, e após o estudo de transgressão, ficção transgressiva enquanto gênero literário, sua posição nos sistemas literários de partida e chegada, bem como os impasses tradutórios que apresenta, faremos um relato da experiência, onde, buscando respaldo teórico, discutiremos e justificaremos escolhas feitas e decisões tomadas em determinados trechos. É um momento importante da pesquisa, pois, ao escrever sobre tradução, somos forçados a refletir sobre ela e temos a oportunidade de vê-la sob novos ângulos.

A escolha pelo tema, parte, em primeiro lugar, de um interesse pessoal pela ficção transgressiva como um todo e, em particular, pelo escritor Chuck Palahniuk. Julgamos ser um exercício de tradução relevante, por conta dos recursos linguísticos, estruturais e estilísticos empregados em seus textos, além dos temas que consideramos desafiadores, por serem desconfortáveis. Da mesma forma, consideramos que muitos dos temas presentes nos textos transgressivos, tidos como polêmicos e tabus, precisam ser mais debatidos, vistos com mais naturalidade a ponto de saírem das margens e, talvez, até deixarem de ser transgressivos, como é o caso do aborto, e consideramos o meio acadêmico uma excelente plataforma para discussões dessa natureza. Infelizmente, ainda há poucos trabalhos das áreas de Letras, Literatura e Estudos da Tradução que abordam a ficção transgressiva e seus objetos e, por isso, julgamos importante contribuir para a pesquisa acadêmica desse gênero no Brasil, de modo a incentiva-la.

Para fins metodológicos, a pesquisa foi dividida em etapas. A primeira inclui a) leitura e análise dos contos de Palahniuk e identificação dos elementos mais importantes de cada texto, que representem algum desafio de tradução ou contribuam de forma significativa para uma discussão relativa aos Estudos da Tradução; b) seleção dos contos que serão traduzidos para o projeto, tendo como base diferentes desafios de tradução, como marcas dialetais, estruturas textuais e aspectos culturais, que são, também, marcas transgressoras por conta da maneira como são utilizadas nos textos, associadas aos temas; c) tradução dos contos selecionados; e, paralelamente, d) identificação das estratégias de tradução utilizadas em cada texto, discutidas em comentários sobre o processo tradutório. 
A segunda etapa consiste em aproximar o exercício tradutório posto em prática no projeto com teorias reconhecidas a respeito do processo. Não se tratam de etapas exclusivas ou separadas, pois acreditamos que a teoria e prática da tradução são interdependentes e auxiliam-se mutuamente. Para tal foi reservado um momento para a leitura de textos que poderiam ou não ser relevantes para o projeto, com o objetivo de montar a bibliografia teórica que o integra. Buscamos, nesse momento, uma literatura que contribua com nossas discussões sobre transgressão na literatura, literatura como agente social, ficção transgressiva como gênero, tradução como ponte cultural e tradução como forma de transgressão. Nesse momento, já tendo identificado os principais impasses de tradução, também buscaremos a bibliografia que auxilie nossa tradução de elementos como oralidade na narrativa, tradução de humor etc., além de consultar obras transgressivas já traduzidas para o português e obras de escritores brasileiros que apresentariam elementos transgressivos, de forma a estabelecer precedentes para a tradução que propomos.

A terceira etapa é dedicada ao relato pessoal do processo de tradução, conforme mencionamos anteriormente, com o levantamento das principais dificuldades $\mathrm{e}$ apresentação das soluções para os problemas encontrados. A tradução completa dos contos acompanhará a dissertação em anexo e em forma de tabela, com uma coluna para o texto de partida e uma para o texto de chegada, a fim de facilitar a visualização e comparação dos dois.

Este trabalho está dividido em três capítulos. No Capítulo 1, apresenta-se o conceito de transgressão segundo autores como Michel Foucault, M. Keith Booker e Robin Mookerjee, na intenção de identificar as características do elemento transgressivo. Busca-se, ainda, compreender o papel ocupado pela transgressão dentro e fora da literatura, considerando estudos realizados acerca do tema para determinar de que modo a transgressão opera como agente de mudanças sociais, agitadora de causas e inquietadora. Atentamo-nos, também, ao que escreveu Mikhail Bakhtin sobre o carnaval e a carnavalização da linguagem, que tudo tem a ver com a ficção transgressiva e a forma como seus temas e narrativas giram em torno de personagens marginalizadas buscando um lugar de pertencimento e unidade coletiva.

Partimos, em seguida, para o estudo da transgressão no romance moderno. Traçamos um panorama dos acontecimentos históricos a partir da década de 1950 que coincidiram com (ou causaram?) o surgimento de grandes obras de caráter transgressivo, além de terem influenciado de forma crescente a literatura produzida ao longo das décadas 
seguintes e que, em conjunto, deram origem à ficção transgressiva que temos hoje. Apresenta-se, pois, a origem da expressão "ficção transgressiva" e faz-se uma tentativa de descobrir, a partir dessa perspectiva histórica, se aquela função de agente social transformador, questionador e inquietador continua em vigor na literatura transgressiva atual ou se perdeu força ao longo dos anos e textos, tendo como nova prioridade o papel de entreter.

O restante do capítulo é dedicado ao autor e textos com os quais escolhemos trabalhar. Apresentamos uma breve biografia do autor Chuck Palahniuk, seu histórico editorial, a recepção crítica de suas obras e os principais temas nelas abordados, bem como aspectos importantes de sua escrita. Em seguida, introduz-se a obra estudada, Make something up: stories you can't unread (2015), partindo para a análise dos contos que traduzimos: "Knock-knock", "How Monkey got married, bought a house and found happiness in Orlando", "Zombies" e "Loser".

O Capítulo 2 é intitulado "Transgressão e tradução" e dedica-se a pensar nas particularidades que acompanham a tradução de um texto transgressivo. Primeiramente levanta-se a hipótese de que, por se tratarem de textos tão culturalmente, socialmente e politicamente marcados, com intuito inicial de causar algum tipo de efeito diretamente ligado a essas marcas, sua tradução deve preservar esses elementos, tomando para si a função de pôr o outro em evidência, causar estranhamento, lembrar ao leitor que o mundo é mais que sua própria cultura e, a partir disso, fazê-lo refletir criticamente sobre ela. Aproveitamos esse momento para considerar se a tradução não seria, automaticamente, um ato transgressivo de violência.

Ainda no Capítulo 2, dedicamos um momento para estudar a teoria dos polissistemas de Itamar Even-Zohar e os estudos descritivos da tradução de Gideon Toury como base para tentar compreender em que lugar de insere a ficção transgressiva no sistema literário brasileiro e o que motiva sua tradução. Em seguida, partimos para a discussão dos gêneros textuais com os quais trabalhamos, o conto e a fábula, e das dificuldades encontradas quando do processo de tradução, sejam elas relacionadas a interpretação do texto, a lidar com os temas tabus e imagens incômodas que o texto evoca, ou diretamente concernentes à sua tradução em níveis de língua e letra. Cabe aqui mencionar como o tradutor se porta diante desse gênero de texto, questionando se há ou não autocensura de sua parte ao lidar com a linguagem, temática e estrutura textual presentes na literatura transgressiva. 
No Capítulo 3, apresentamos, finalmente, nosso projeto de tradução e as estratégias de que nos valemos para aplica-lo aos contos. Explicamos de que forma a linguagem ou referências dos textos se mostraram desafiadoras, bem como nossas escolhas de tradução, nossa interpretação de trechos ambíguos, os resultados de nossas pesquisas e soluções encontradas para passagens problemáticas. É uma tentativa, primeiramente, de traduzir de forma transgressiva um texto que também o é, continuando este aberto a novas revisões e interpretações. 


\section{CAPÍTULO 1}

\subsection{Transgressão e tradição}

$\mathrm{Na}$ introdução de sua obra Techniques of subversion in modern literature: transgression, abjection and the carnivalesque (1991), M. Keith Booker diz que, de acordo com os mitos da cultura judaico-cristã, a existência humana começou com um ato de transgressão: Adão comeu o fruto proibido e foi expulso do paraíso, e, como Adão comenta com Dante em Paraíso XXVI, sua expulsão não se deu por provar do fruto propriamente dito, mas por transgredir uma barreira, desobedecer uma regra (BOOKER, 1991, p. 1). Booker tem como objetivo mostrar, ao longo do livro, que a transgressão é elemento natural e fundamental da imaginação e da criatividade e, portanto, da literatura, fazendo-se presente, de uma forma ou de outra, na obra de todos os escritores.

Como forma de legitimar seu argumento, ele preenche os capítulos do livro com análises de uma série de autores canônicos que considera transgressivos, como Geoffrey Chaucer, James Joyce, Thomas Pynchon, Virginia Woolf, Salman Rushdie, entre outros, constituindo um conjunto de textos diversos em que a mistura de gêneros sexuais, gêneros literários, nacionalidades, estilos, contextos socioculturais e orientações políticas possibilita discutir a transgressão a partir de vários pontos de vista.

Já na introdução, intitulada "Is literary transgression stupid?", ao tentar justificar seu interesse pelo tema, Booker faz as afirmações que consideramos ser mais relevantes para a pesquisa: sua obra não se trata de tentar provar que transgressões literárias existem, pois disso ninguém duvida, mas de investigar "como essas transgressões agem e se elas importam no sentido real de contribuir para uma mudança social genuína" (1991, p. 4, tradução nossa) ${ }^{2}$. O autor acredita que nem todo texto literário é necessariamente transgressivo em sua essência, nem mesmo aqueles com o propósito de sê-lo, mas todo texto literário pode ser transgressivo dependendo de como é lido, ao que ele então sugere estratégias de leitura que permitem identificar e acentuar a energia transgressiva das obras em diferentes casos. Booker não valoriza a transgressão simplesmente por ser transgressão, salientando que a transgressão literária só tem força política de verdade quando é direcionada a um alvo específico, pois, "na literatura, pelo menos, um rebelde sem causa não é rebelde nenhum" (1991, p. 11, tradução nossa) ${ }^{3}$.

\footnotetext{
2 "how these transgressions function and whether they matter in the real sense of contributing to genuine social change”. (1991, p. 4).

3 "In literature, at least, a rebel without a cause is no rebel at all". (1991, p. 11).
} 
Considerando a transgressão, de forma geral, como um manifesto contra hierarquias, taxonomias ou sistemas restritivos de todos os tipos, Booker encerra texto introdutório ressaltando a importância de um estudo crítico desse tema, para que a literatura tenha de fato poder de operar mudanças sociais. Ele afirma que

\begin{abstract}
todas as obras da literatura têm algum potencial transgressivo, mesmo quando aparentam estar totalmente de acordo com as ideologias dominantes. Como a literatura tende a exagerar os efeitos e ideias que importa de seu contexto sociocultural, tais obras podem expor contradições e 'rachaduras' em ideologias dominantes que em outro caso talvez não fossem aparentes. Além disso, estudos comparativos de tais obras são úteis para acentuar, por meio do contraste, o poder de obras que são efetivamente transgressivas em um sentido mais direto. [...] Dada a dificuldade de iniciar qualquer mudança social verdadeira, críticos politicamente engajados devem se valer de toda a ajuda possível. (1991, p. 17-18. Tradução nossa) ${ }^{4}$.
\end{abstract}

Para explorar dentro dos textos a dinâmica da transgressão literária, Booker faz uso das noções de carnaval exploradas por Mikhail Bakhtin ${ }^{5}$, bem como das noções de abjeção delineadas por Julia Kristeva ${ }^{6}$, o que se justifica pelo potencial transgressivo que ambas têm de lembrar às culturas dominantes aspectos da vida que tentam reprimir, como o lado animalesco e mortal do ser humano. O carnaval de Bakhtin, inclusive, é especialmente importante para a análise do autor e dos textos que selecionamos para traduzir, e, por esse motivo, vamos explorar um pouco mais esse conceito.

Mikhail Bakhtin, na obra A cultura popular na Idade Média e no Renascimento: o contexto de François Rabelais (1999), discute e apresenta uma inovadora teoria da cultura cômica popular nos períodos da Idade Média e Renascimento, desenvolvendo um pensamento sobre o carnaval e a carnavalização da linguagem, entre outras questões associadas, enquanto busca compreender a influência de tal cultura na obra de Rabelais, autor que considera um dos maiores nomes da literatura europeia, mas que é (ou era até então), na Rússia, “o menos popular, menos estudado, o menos compreendido e estimado

\footnotetext{
4 “all works of literature have some transgressive potential, even when they appear to be fully in complicity with dominant ideologies. Because literature tends to exaggerate the effects and ideas it imports from its cultural and historical context, such works can expose contradictions and "seams" in dominant ideologies that might not otherwise be apparent. Moreover, comparative studies of such works are useful to highlight by contrast the power of works that are effectively transgressive in a more direct sense. [...] Given the difficulty of initiating any genuine social change, politically committed critics can use all the help they can get." (1991, p. 17-18).

${ }^{5}$ Para tratar do carnival bakhtiniano, M. Keith Booker utiliza principalmente a obra A cultura popular na Idade Média e no Renascimento, de Bakhtin. Ver BAKHTIN, M. M. A cultura popular na Idade Média e no Renascimento: o contexto de François Rabelais. Trad. Yara Frateschi Vieira. São Paulo: Hucitec, 1987.

${ }^{6}$ Para as noções de abjeção de Julia Kristeva, Booker utiliza principalmente o título Powers of horror. Ver KRISTEVA, Julia. Powers of horror: an essay on abjection. Trad. Leon S. Roudiez. New York: Columbia University Press, 1982.
} 
dos grandes escritores da literatura mundial" (BAKHTIN, 1999, p. 1). A obra foi inicialmente escrita como tese de doutorado e submetida à academia de Moscou durante a Segunda Guerra Mundial e as ideias polêmicas causaram tanto desconforto e desacordo entre os membros da banca que o título foi negado ao pesquisador, além de só ter sido publicada muitos anos depois, em 1965, também devido ao conteúdo.

$\mathrm{Na}$ obra, Bakhtin analisa os festejos populares que aconteciam ao longo do ano durante a Idade Média e o Renascimento, em geral associados a comemorações sagradas. Ele percebe o carnaval como um conjunto de manifestações da cultura popular desses períodos, um momento de inversão, libertação e extravasamento, uma ruptura de barreiras hierárquicas, ideológicas, sociais, de idade e de gênero. O sentimento de unidade coletiva reina no carnaval, eliminando as identidades individuais por meio da mistura do povo com o povo, valendo-se, inclusive, de máscaras e fantasias para criar um só corpo coletivo em um espetáculo quase teatral, porém sem atores, palco ou texto ensaiado. O carnaval "se situa na fronteira entre a arte e a vida" (BAKHTIN, 1999, p. 6) e todo o povo é ao mesmo tempo ator e expectador vivendo segundo a mais importante lei carnavalesca: a da liberdade. As demais leis, restrições e proibições, padrões impostos pelo sistema social cotidiano, todas as formas de hierarquia que impõem medo, reverência e etiqueta são suspensas, substituídas pela coletividade, pelo riso, pela expressão cômica.

Essa suspensão temporária das relações de poder teve como consequência a criação de uma linguagem carnavalesca típica: "Elaboravam-se formas especiais do vocabulário e do gesto da praça pública, francas e sem restrições, que aboliam toda a distância entre os indivíduos em comunicação, liberados das normas correntes da etiqueta e da decência" (BAKHTIN, 1999, p. 9). Tal linguagem era carregada de lirismos e se refletia nas obras cômicas verbais com características paródicas, tanto orais quanto escritas, em latim ou língua vernácula, que circulavam ao longo da Idade Média e Renascimento, dedicadas, em geral, a parodiar textos das cerimônias religiosas (como salmos, orações e Evangelhos), textos oficiais (como testamentos e decisões dos concílios) e demais manifestações verbais tradicionais, como cânticos de Natal, lendas e até romances de cavalaria (BAKHTIN, 1999, p. 13). O carnaval não é, evidentemente, um fenômeno literário, mas quando essa linguagem concreto-sensorial simbólica se une à linguagem literária, surge o que Bakhtin chama de carnavalização da literatura (BAKHTIN, 1981, p. 105), cuja influência é claramente vista em textos como Decameron, de Boccaccio (1349-51), Os contos da Cantuária, de Chaucer (1386-7/1400) 
e $O$ elogio da loucura, de Erasmo de Rotterdã (1508), todos manifestações paródicas do riso carnavalesco que são, por sua vez, transgressivos.

Não se trata, aqui, do carnaval contemporâneo que conhecemos, celebrado no período que antecede a quaresma, mas acreditamos ser possível transportar e aplicar as noções bakhtinianas de carnaval para outras manifestações da cultura popular, inclusive para analisar o uso de temáticas e linguagem carnavalescas na literatura transgressiva que estudamos nessa dissertação. Com isso em mente, voltamos às considerações de M. Keith Booker, que ressalta que, apesar de o carnaval ser tão claramente um palco para a expressão de energias subversivas - incluindo a carnavalização da linguagem -, não se deve ignorar que ele é também uma forma sancionada de subversão com o propósito de dispersar as tensões sociais e impedir uma verdadeira subversão (BOOKER, 1991, p. 5). É um tipo de válvula de escape para as massas, que leva o autor a questionar se a permissão supervisionada de um pouco de transgressão não poderia aumentar o poder dos regimes autoritários.

Terry Eagleton também comenta no livro Walter Benjamin, or towards a revolutionary criticism, de 1981, que o carnaval é um belo exemplo "da mútua cumplicidade entre lei e libertação, poder e desejo, que se tornou um tema dominante do pessimismo pós-marxista contemporâneo"7 (EAGLETON, 1981, p. 149. Tradução nossa). Ele afirma que, por um lado, o carnaval bakhtiniano é excessivamente utópico e otimista, sendo comemorado com tanto vigor que seu papel político-social corre o risco de se perder - afinal de contas, é uma forma autorizada de transgressão, uma explosão de expressão popular mantida sob controle, "tão perturbadora e relativamente ineficaz quanto uma obra de arte revolucionária" (EAGLETON, 1981, p. 147); entretanto, por outro lado, exatamente por ser um evento tão permissivo, o carnaval reafirma sua própria transgressão ao ser autorizado pelas instituições de poder e, assim, sua utopia é subordinada às funções satíricas (EAGLETON, 1981, p. 148).

A questão da transgressão na literatura é bastante complexa e lida com a função e propósito da literatura, o impacto das ideias sobre instituições e as interações entre cultura e política. A situação fica ainda mais complicada quando se tenta definir transgressão e seu papel de agente social. Isso porque, segundo Booker, nem mesmo os trabalhos mais transgressivos da literatura incitaram seus leitores a irem imediatamente para as ruas em

\footnotetext{
7 "Indeed from one viewpoint carnival may figure as a prime example of that mutual complicity of law and liberation, power and desire, that has become a dominant theme of contemporary post-Marxist pessimism." (EAGLETON, 1981. p. 149).
} 
protesto (1991, p. 3), o que seria de se esperar de um texto com propósitos de manifesto. A literatura transgressiva, no entanto, atua de forma sutil, desbancando gradualmente modelos de pensamento que contribuem para perpetuar estruturas políticas opressivas. Sendo assim, é impossível compreender o verdadeiro poder da literatura, a não ser quando consideramos o pavor que os regimes totalitários tinham e têm de obras que consideravam perigosas.

Robin Mookerjee afirma na introdução de sua obra, Transgressive fiction: the new satiric tradition (2013), que a literatura carrega as principais crenças da sociedade em dado período e por esse motivo, quando romances literários evidenciam esses aspectos socioculturais, incomodam mais do que textos de ficção popular, vídeo games ou TV a cabo (2013, p. 2). Assim como Booker, Mookerjee também traça um panorama da tradição transgressiva da literatura, citando nomes como Marquês de Sade, Arthur Rimbaud, François Rabelais, entre outros, até chegar em autores transgressivos contemporâneos, como Kathy Acker, Bret Easton Ellis e Irvine Welsh. Mookerjee também faz um paralelo da transgressão moderna com a sátira clássica, afirmando que as duas seriam recursos literários para expressar - de forma velada ou não - insatisfações com a sociedade.

No caso da ficção transgressiva contemporânea, é possível que os autores tenham encontrado uma estratégia para causar a inquietação e estimular o pensamento crítico dos leitores. Robin Mookerjee a sintetiza muito bem quando diz que os

\begin{abstract}
Satiristas transgressivos lidam com temas críticos sem estabelecer um posicionamento moral e tratam comportamentos bizarros como se fossem absolutamente normais. Além disso, mantêm um certo anonimato autoral que torna difícil perceber qualquer intenção do trabalho para determinar seu significado como uma ofensa. [...] Esses são os elementos essenciais da transgressão literária na minha definição: ela conquista um público entre as elites culturais enquanto se mantém neutra e se recusa a escolher lados nos debates que surgem dos temas da obra. Essa estratégia força o público a encarar o assunto da obra de forma direta, e não através da ótica de um sistema ou teoria. (MOOKERJEE, 2013, p. 2 e 3. Tradução nossa) ${ }^{8}$.
\end{abstract}

A tentativa de neutralidade é o que separa a sátira transgressiva da sátira clássica, cuja postura implica posicionamento e ponto de vista definidos. Para auxiliar esse

\footnotetext{
8 "Transgressive satirists treat flashpoint subjects without taking any kind of moral stand and treat bizarre behavior as if it were absolutely normal. Further, they maintain a sort of authorial anonymity that makes it difficult to extract some semblance of intent from the work to clarify its meaning as a gesture. [...]These are the essential elements of literary transgression as I define it: it achieves an audience among the cultural elites while maintaining neutrality, a refusal to take sides in the debates brought up by the subject matter of the work. This masterstroke forces the audience to face the subject matter of the work directly, rather than through the optic of a system or theory." (2013, p. 2-3).
} 
distanciamento, os autores transgressivos se valem de estratégias como o exagero, ironia, carnavalização das personagens e situações — tudo é levado ao extremo. Hoje em dia isso acontece de forma propositalmente exagerada, em uma tentativa de chocar e conquistar um leitor que pensa já ter visto de tudo, uma vez que tem fácil acesso a todo tipo de informação e entretenimento por meio de mídias diversas, como televisão e internet. Em geral, o conteúdo que chega até esse leitor já tem opiniões políticas, sociais e culturais estabelecidas, e contribuirá para que o indivíduo tome um partido que não é essencialmente seu, mas que lhe foi forçado goela abaixo. O que a ficção transgressiva tenta fazer é chamar e manter a atenção do leitor através dos recursos já mencionados e apresentar determinado tema da forma mais imparcial possível para, assim, incentivar seu pensamento crítico, fazê-lo parar e refletir, pesquisar a respeito, interessar-se e, só então, tomar uma posição. É claro que essa tentativa de imparcialidade nem sempre é bemsucedida e devemos lembrar que o conceito de neutralidade, em geral, não passa de uma utopia; o autor é parte de um determinado contexto e carrega uma bagagem histórica, política, social e cultural que, de uma forma ou de outra, se refletirá em seu texto e, portanto, neutralidade deve ser interpretada, nesse caso, como a suspensão de valores morais.

Ao levar em conta as contribuições de Booker e Mookerjee, a expressão transgressiva parece ter sido incorporada ao discurso literário com bastante facilidade. Há, no entanto, um grande problema: a maior parte dos trabalhos que têm ou poderiam ter impacto político-social eficiente costumam ser complexos e compreendidos apenas dentro do ambiente acadêmico, não conseguindo alcançar o grande público para estimular ações e pensamentos revolucionários. Além disso, a obra transgressiva corre o risco de ser absorvida pela cultura de massa - que não é determinada pelo povo, mas pelas mídias de comunicação sob o domínio de instituições de poder e grandes corporações - e de, assim, perder seu caráter crítico e transgressivo, como já aconteceu diversas vezes. Um exemplo disso é o 1984, de George Orwell, que foi de romance de inquietação a reality show, mostrando como a mídia e a sociedade mecanizam o indivíduo, transformam-no em um fantoche institucional que, ao invés de lutar contra o controle governamental, que vigia cada um de seus passos com câmeras, registros telefônicos e bancários e muito mais, busca esse encarceramento de vitrine, como no programa Big Brother. A grande ironia é que, para esse indivíduo, estar dentro da TV lhe dá uma sensação de pertencimento muito maior do que teria na vida real, pois o que ele vê na TV é para ele a realidade ideal. 
Uma outra abordagem teórica da transgressão e literatura que não podemos deixar de mencionar é a de Michel Foucault. Em seus primeiros textos, e durante toda a década de 60, a linguagem literária é um tema recorrente. O que interessa ao autor, mais do que a própria Literatura, é a função transgressora do pensamento, que se torna possível por meio da linguagem. Nesse momento, essa função transgressora que o interessa ainda não lida diretamente com engajamentos políticos, apesar de eles poderem estar presentes, mas com o poder que a linguagem tem de transpor seus próprios limites para superar aqueles estabelecidos por instituições de poder e pela academia.

Em 1963, Foucault escreveu um ensaio intitulado "Prefácio à transgressão", onde faz uma análise da obra do escritor francês Georges Bataille. Para ele, Bataille era um filósofo que, por meio de sua escrita fragmentada, pretendia fundar uma ciência da transgressão dos limites. Foucault entende que a linguagem de Bataille se posiciona no vazio deixado pela morte de Deus, conseguindo afastar-se da dialética e do antropocentrismo e atingindo a desconstrução do sujeito, que se expressa pela busca de sua própria morte. Essa morte não é necessariamente física, mas a morte das crenças e ideologias sociais inerentes ao sujeito e, ao rejeitá-las, a transgressão acontece.

Foucault admite, porém, que

$$
\begin{aligned}
& \text { A transgressão é um gesto relativo ao limite; é aí, na tênue espessura da linha, } \\
& \text { que se manifesta o fulgor de sua passagem, mas talvez também sua trajetória } \\
& \text { na totalidade, sua própria origem. A linha que ela cruza poderia também ser } \\
& \text { todo o seu espaço. O jogo dos limites e da transgressão parece ser regido por } \\
& \text { uma obstinação simples; a transgressão transpõe e não cessa de recomeçar a } \\
& \text { transpor uma linha que, atrás dela, imediatamente se fecha de novo em um } \\
& \text { movimento de tênue memória, recuando então novamente para o horizonte do } \\
& \text { intransponível. Mas esse jogo vai além de colocar em ação tais elementos; ele } \\
& \text { os situa em uma incerteza, em certezas logo invertidas nas quais o pensamento } \\
& \text { rapidamente se embaraça por querer apreendê-las. (FOUCAULT, 2009, p. 34). }
\end{aligned}
$$

Da mesma forma, qualquer linguagem, estética, discurso literário ou afim que seja inovador e transgressivo quando de seu surgimento, logo será assimilado pela massa e institucionalizado, passando a ser limite, não mais transgressão.

É certo que, mesmo com essa condição, a linguagem sempre conseguiu encontrar uma forma de se superar e se renovar, mas, ainda assim, na década de 1970, Foucault se afasta da escrita literária, considerando-a uma forma de pensamento fraca, tal qual havia feito com a filosofia nos anos 1960. Ele passa a buscar manifestações mais eficazes de transgressão, como o que ele chama de "discursos anônimos", relatos, registos escritos ou depoimentos de pessoas marginalizadas, sem voz, encarceradas e à beira da morte. 
Marco Antônio de Sousa Alves, em artigo contido no periódico Em tese, "A escrita literária em Foucault: da transgressão à assimilação" (2013), conta que

\begin{abstract}
Em Vigiar e punir, essa assimilação e pobreza da literatura, em comparação à transgressão e riqueza do discurso dos homens infames, fica visível na distinção traçada entre o "discurso do cadafalso" (discours de l'echafaud) e a "literatura do crime" (litterature du crime). O primeiro discurso corresponde às últimas palavras do condenado, pronunciadas no seio do grande espetáculo público do suplício, possuindo um caráter transgressor, descontrolado, que permitia a irrupção de uma verdade incômoda. Já o segundo discurso corresponde à reescrita estética do crime, que o glorifica, embeleza e engrandece. (ALVES, 2013, p. 25).
\end{abstract}

Foucault considera esses discursos perturbadores e instigantes, mas nunca belos, por medo de que isso os faria ser assimilados pelas instituições literárias também. Para ele, essas pessoas reais diminutas apresentam uma intensidade que supera a de qualquer personagem de ficção, e é nessa noção - a de que a degradação do sujeito real consiste na maior forma de transgressão - que se baseiam os escritores transgressivos pós-modernos de língua inglesa.

\title{
1.2 A transgressão no romance moderno
}

Os textos foucaultianos, em especial aqueles sobre sexualidade e vozes marginalizadas, embora não sejam os únicos a contribuir com o tema, têm um peso muito grande para os estudos da transgressão por porem em evidência uma subcorrente literária que ganhava cada vez mais espaço nos Estados Unidos. Vemos surgir, a partir da década de 1950, textos com características inovadoras que começam a delinear o caminho da ficção transgressiva em língua inglesa que temos hoje, que são frutos do contexto histórico do país (e do mundo) naquele momento.

Com o fim da Segunda Guerra Mundial, os Estados Unidos vivenciaram um momento de grandes paradoxos: por um lado, a prosperidade econômica do país que tornava os Estados Unidos uma das grandes potências mundiais começava a beneficiar a classe média, bens de consumo, educação e cultura se tornavam mais acessíveis e a perspectiva de um futuro promissor gerava um sentimento de otimismo; por outro lado, a desigualdade racial, social, econômica e de gênero permanecia forte e, acima de qualquer coisa, havia a tensão da Guerra Fria e o medo constante de que o conflito ideológico com a União Soviética chegasse às vias de um embate militar.

Martin Halliwell, em seu livro American culture in the 1950s (2007), afirma que a década de 1950, apesar de predominantemente conservadora devido à paranoia política e histeria anticomunista instaladas a partir de 1946, deu espaço a correntes liberais que 
resultaram na explosão de ativismo político dos anos 1960 (HALLIWELL, 2007, p. 2-3). Foi um momento em que as margens - jovens, negros, mulheres e gays - começavam a ganhar voz e isso se refletia nas expressões artísticas e culturais de toda natureza. Para a literatura, em especial, o início dos anos 1950 foi um período de transição, em que os autores buscavam se afastar do modernismo que caracterizava a literatura entre Guerras, partindo para uma estética literária ainda indefinida. Ao mesmo tempo, eles lidavam com temas inspirados nos eventos internacionais que sucederam a Segunda Guerra Mundial, que não podiam ser ignorados, mas que implicavam um nível de comprometimento político com causas sociais que era visto com maus olhos pela censura anticomunista, gerando medo entre os autores (HALLIWELL, 2007, p. 52-53). Esse medo, no entanto, não impediu que os escritores se expressassem, desafiando a "cultura do consentimento", como ficou conhecida na década de 1950 devido à aceitação generalizada da ideologia liberal-democrata e do incentivo da mídia para que o povo se satisfizesse com o conforto material que o prestígio do país oferecia e não questionasse as decisões políticas que contribuíram para sua ascensão global.

Morris Dickstein (2002, p. x-xi) afirma que a década foi "um momento em que os sujeitos de fora se tornavam sujeitos de dentro, quando a literatura americana [...] estava se tornando descentralizada, ou multicentralizada, alimentando-se de novas energias da periferia" (apud HALLIWELL, 2007, p. 53) ${ }^{9}$, ao que Halliwell segue dizendo que tal impulso "multicentralizado" é particularmente relevante para compreender a complexidade da literatura norte-americana da década de 1950, com constante tensão entre centro e periferia, variando entre engajamento e fuga dos acontecimentos contemporâneos e questões político-sociais, em especial considerando a emergência de vozes literárias de imigrantes, judeus americanos e afro-americanos.

Outro fato que contribuiu para a ascensão de autores marginais foi o crescimento do mercado do "mass paperback" durante e após a Segunda Guerra. "Mass paperback" se refere a livros em brochura de qualidade muito inferior aos tradicionais em brochura ou capa dura; o papel costuma ser mais fino e o espaçamento e tamanho da fonte, menores, de forma a tornar sua impressão mais barata e o livro mais acessível ao grande público. Essas edições, geralmente vendidas em farmácias, mercados e lojas de departamento, mudaram a relação entre os autores e leitores, aproximando-os e abrindo espaço tanto

\footnotetext{
9 “"a moment when outsiders were becoming insiders, when American literature . . . was becoming decentred, or multicentred, feeding on new energies from the periphery'." (DICKSTEIN, 2002, p. x-xi, apud HALLIWELL, 2007, p. 53).
} 
para um novo perfil de leitores quanto para gêneros que fugiam da literatura considerada séria, como romances policiais e ficção científica. Foi dessa forma que autores como William Buroughs e Jack Kerouac encontraram um leitorado e conseguiram ser publicados.

Halliwell admite que é muito difícil classificar a literatura norte-americana em uma década em que a situação dos Estados Unidos era, de forma geral, paradoxal. Muitos movimentos literários aconteciam, ao mesmo tempo, em partes diferentes do país; na poesia, por exemplo, o pesquisador identifica quatro grupos distintos - os poetas beat, os poetas do Renascimento de São Francisco, os poetas de Black Mountain e os poetas da Escola de Nova York - como forma de mostrar a diversidade da literatura que estava sendo produzida (HALLIWELL, 2007, p. 57-58). Apesar de não conseguir identificar um movimento uno, rígido e específico da década, Halliwell diz que, por consequência da fusão de extremos opostos (seja político, cultural, social ou econômico) que influenciava os autores, uma característica dominante na escrita do pós-guerra é a tragicomédia, comprovada pela presença constante do anti-herói norte-americano na ficção do fim dos anos 1940 e 1950, que Halliwell chama de "ficções do desconforto". Esse desconforto se refere ao lugar que se espera que o indivíduo de classe média ocupe na sociedade norteamericana no pós-guerra: dos homens que acabaram de voltar da guerra, espera-se um retorno completo à posição de chefe da casa, que trabalhe um emprego corporativo, seja bom pai, bom marido e se acomode com a vida no subúrbio; da mulher, que havia encontrado mais espaço no mercado de trabalho enquanto os homens estavam na guerra, espera-se que abdiquem de sua recém adquirida individualidade e volte a se dedicar aos afazeres domésticos, ser boa mãe, boa esposa e abra mão de sua independência e sexualidade. O problemático lugar da mulher na sociedade é posto em evidência, inclusive, pelo fato de os autores publicados no período serem, em sua grande maioria, homens, escrevendo sobre as inquietações masculinas de personagens masculinos (mesmo quando eram negros, judeus, gays ou outras minorias sociais, ainda eram homens), cenário que permanece sem muita alteração nos anos que seguem.

Esse sentimento de inquietação, de não pertencimento, de não conformidade com as estruturas sócio-políticas, juntamente com a pressão das amarras e expectativas sociais e tensão de uma possível guerra, inspirou alguns escritores dessa década a criarem obras intimistas, erráticas e de caráter confessional, que representavam a busca do sujeito pela sua individualidade através de meios pouco ortodoxos, que transgridem o conjunto de regras e dogmas impostos pela sociedade. São exemplos dessas criações Catcher in the 
rye (1951), de J. D. Salinger, The invisible man (1952), de Ralph Ellison, e Lolita (publicado na França em 1955, oficialmente lançado nos EUA apenas em 1958), de Vladmir Nabokov.

A publicação de Junkie (Junky, nas edições subsequentes), diário autobiográfico do vício em heroína de William Burroughs, em uma edição de mass paperback em 1953, é um marco na literatura norte-americana. Nas palavras de Halliwell: "O que Junky apresenta, talvez pela primeira vez na ficção americana do século XX, é o lado oculto da cultura nacional: um submundo de criminalidade, linguagens secretas e diversas formas de sexualidade" (HALLIWELL, 2007, p. 77. Tradução nossa). Sua aceitação abriu espaço para que fossem publicados os grandes textos da Geração Beat, como Howl (1955), de Allen Ginsberg, On the road (1957) e The darma bums (1958), de Jack Kerouac, e a obra prima do próprio William S. Burroughs, Naked lunch (1959), que causaram grande impacto na sociedade norte-americana com sua tentativa coletiva de se libertarem da inércia cultural por meio de drogas, álcool, sexo e jazz, em textos que davam voz às margens e inovavam, também, na estrutura e estética literárias.

Essas obras ainda não se identificam como transgressivas no período, mas lidam com tabus - como pedofilia, aborto e uso de drogas -, transpõem ou contornam barreiras sociais e apresentam inovações linguísticas e literárias com relação aos modelos vigentes, o que leva Robin Mookerjee a afirmar que Lolita e Naked lunch são os romances norteamericanos mais especificamente influentes na tradição transgressiva (MOOKERJEE, 2013, p. 170).

Influenciados pela Geração Beat e incentivados pelo sentimento de insatisfação, em especial dos jovens, os anos 1960 veem surgir nos EUA uma série de movimentos contraculturais reivindicando maior liberdade do indivíduo, seja de pensamento, de expressão, sexual, religiosa etc. Dando continuidade ao crescimento econômico e político e ao desenvolvimento tecnológico que havia iniciado na década anterior, os Estados Unidos mostraram para o mundo na década de 1960 seu poder e hegemonia, consolidando-se ainda mais como grande potência, exportando para outros países e continentes sua cultura de forma massiva por meio do cinema, da literatura, da música, artes plásticas e também empresas multinacionais que começavam a se expandir para territórios internacionais.

Felipe Guimarães, em seu artigo Traços da contracultura na cultura brasileira da década de 1960 (2012), afirma que 
Boa parte da sociedade adulta estadunidense apoiava as ações do governo, ações pacíficas e não-pacíficas, pois a era intensa a propaganda com intuito de enaltecer o sentimento de patriotismo nacionalista coletivo, as guerras eram travestidas de missões civilizatórias e a expansão do capitalismo travestida de missão desenvolvimentista e anticomunista. [...] Não havia esperanças de luta contra o sistema para o jovem estadunidense, a esquerda socialista tradicional provara que era tão burocratizada e repressora quanto a direita capitalista. (GUIMARÃES, 2012, p. 6).

Dessa forma, os jovens buscaram a saída em um mundo alternativo e, de sua recusa de seguir o modelo da cultura dominante e da luta pelos Direitos Civis e expansão dos direitos de minorias, nascem movimentos inicialmente chamados de underground, movimentos de subcultura juvenis, como os hippies (o mais icônico deles, cuja expressão mais famosa foi o festival Woodstock, que reuniu cerca de meio milhão de pessoas em uma fazenda no estado de Nova York em 1969), diggers, Nova Esquerda (yippies), Panteras Negras, Hell's Angels e Weathermen. Como reflexo disso na literatura, foram publicadas obras como A clockwork orange (1962), de Anthony Burgess, One flew over the cuckoo's nest (1962), de Ken Kesey, Last exit to Brooklyn (1964), de Hubert Selby Jr., e Hell's Angels (1966), de Hunter S. Thompson.

O Brasil também teve sua parcela de expressão contracultural nessa década. Além de sua relativa vulnerabilidade econômica em relação aos EUA, o que já o tornava extremamente sujeito à influência da cultura industrializada que importava de lá, também passou por um momento político-econômico crítico com a implementação da ditadura militar, em 1964. Nesse contex to de censura à liberdade de expressão e repressão violenta, surgiram movimentos como a Tropicália, o cinema de Glauber Rocha (dando início ao que hoje se conhece como Cinema Novo), o teatro de Nelson Rodrigues, as pinturas e performances de Hélio Oiticica e, na literatura, nomes como Torquato Neto, Paulo Leminsky e José Agrippino de Paula.

Sobre esta época, M. Keith Booker diz que os movimentos vanguardistas das artes perderam parte de sua força subversiva, pois a sociedade burguesa se apropriava de sua retórica ofensiva para o entretenimento popular. Guimarães de fato afirma que

\footnotetext{
no momento em que os movimentos contraculturais estavam em seu ápice, foram veiculados pelos meios de comunicação em massa, a indústria cultural usou de seus ideais, reivindicações, estilos de vestir, para vender uma imagem específica do jovem, acabando assim por padronizar a própria contracultura. (GUIMARÃES, 2012, p. 5).
}

o que confirma a premissa foucaultiana de que uma transgressão pode facilmente se tornar limite se absorvida pela cultura de massa. 
O ativismo dos anos 1960 continuou na década de 1970, em particular com as lutas das mulheres e de outras minorias políticas. Com o fim da Guerra do Vietnã, novas causas sociais ganharam espaço, como as ambientais e imigracionais. A cultura jovem foi fragmentada em subculturas e surgiram movimentos rebeldes como o Glam, uma reação contracultural ao hippie, trazendo ao centro a comunidade gay, a sexualidade exacerbada e a estética pop decadentista, cujos principais representantes foram David Bowie e Andy Warhol. Outro movimento que surgiu em rejeição ao hippie foi o punk, com caráter anarquista e revolucionário, que uniu fatores políticos, estéticos e culturais à luta, enquanto o movimento hippie, por sua vez, transformou-se em New Age, filosofia de vida que pregava uma nova mentalidade, novo modelo de consciência moral, psicológica, social e espiritual.

O tom de crítica e empoderamento das minorias continua se refletindo na literatura, com a publicação de títulos com elementos transgressivos mais evidentes, como por exemplo, Fear and lothing in Las Vegas (1971), de Hunter Thompson, Breakfast of champions (1973), de Kurt Vonnegut, Crash (1973), de J. G. Ballard e Factotum (1975) e Women (1978), de Charles Bukowski. Também ganhava cada vez mais popularidade o romance de terror, que começara na década anterior com Rosemary's baby (1967), de Ira Levin. Foram lançados clássico do horror como The exorcist (1971), de William P. Blatty, Amityville horror (1977), de Jay Anderson, e uma sequência impressionante de obras de Stephen King: Carrie (1974), Salem's lot (1975), The shining (1977), The stand (1978) e The dead zone (1979), o que indica uma mudança de atitude e interesse dos leitores de ficção.

Os anos 1980 dão continuidade a esses segmentos literários iniciados nos anos 1950 e cresce o número de publicações de autores marginais nos Estados Unidos, caso de autores imigrantes, mulheres, negros, gays etc. Aqui a Literatura Transgressiva já é aceita como uma vertente literária e as publicações são como uma introdução ao "circo de horrores" da transgressão da década seguinte. São lançadas obras como Night at the circus (1984), de Angela Carter, Blood and guts in high school (1984), de Kathy Acker, e Less than zero (1987) e Rules of attraction (1989), de Bret Easton Ellis, autor que viria a causar uma grande comoção no início dos anos 1990 com outro de seus livros.

Vale comentar que a esses autores que compartilhavam características transgressivas em seus textos, foram classificados como pertencentes à "blank generation", um gênero de definições incertas que James Annesley, autor de Blank fictions (1998), acredita qualificar uma série de autores e obras nos quais “[...] Conjuntos 
comuns de temas estão sendo articulados. Há uma ênfase no extremo, no marginal e violento. Há uma atmosfera de indiferença e indolência. Os limites do corpo humano parecem indistintos, embaçados por cosméticos, drogas, doenças e brutalidade" (ANNESLEY, 1998, p. 1).

Essas características se aproximam muito daquelas que entendemos como transgressoras e, a partir de 1991, chegamos à transgressão literária tal qual é conhecida hoje - ou melhor, aos títulos transgressivos mais óbvios que encontramos ao pensar em ficção transgressiva. São lançados nesse ano Generation $X$, do canadense Douglas Coopland, o explícito Frisk, de Dennis Cooper, e o perturbador American psycho, de Bret Easton Ellis. Esses autores já haviam sido publicados antes, mas é com estes trabalhos que atingem notoriedade por meio da tentativa de censura, revolta da crítica e choque geral do público leitor. Colin Harrison, no livro American culture in the 1990s (2010), fala que

\begin{abstract}
Os escritores da "blank fiction" do fim dos anos 1980 e início dos anos 1990 repudiavam os efeitos pirotécnicos da metaficção e optavam, ao invés disso, por vozes minimalistas pouco distintas do ambiente consumista superficial e desenraizado que escolheram como tema. Eles capturaram a sensibilidade de uma classe, em sua maioria, jovem, branca e abastada que parecia estar à deriva em uma cultura sem pontos de referência históricos, e examinaram a invasão das commodities em todos os aspectos da vida. O Generation X (1991), do escritor canadense Douglas Coupland, tornou-se o manual desse movimento mal definido, embora seu tom nostálgico, personagens angustiados que buscam o deserto como lugar de cura e renovação, talvez faça dele uma obra mais modernista do que pós-modernista. É o American psycho (1991), de Bret Easton Ellis que utiliza de forma mais marcante a escrita vazia ["blank"] e despreocupada como forma de crítica. (HARRISON, 2010, p. 55. Tradução nossa. $)^{10}$.
\end{abstract}

"Blank fiction" parecia ser o melhor termo para se referir a esses autores, até que, em 1993, um seminário sobre escrita criativa ministrado por Dennis Cooper inspirou o jornalista Michael Silverblatt a escrever uma reportagem para o Los Angeles Times: "Shock appeal: who are these writers, and why do they want to hurt us?: the new fiction

\footnotetext{
10 'The 'blank fiction' writers of the late 1980s and early 1990s repudiated metafictional pyrotechnics and opted instead for a minimal voice barely distinct from the superficial, deracinated consumer landscape they took for their subject matter. They captured the sensibility of a largely young, white, affluent class seemingly adrift in a culture without historical reference points, and examined the penetration of the commodity into all spheres of life. Canadian write Douglas Coupland's Generation X (1991) was taken up as the handbook of this loosely defined movement, though its nostalgic tone, angst-ridden characters and hankering for the desert as a place of healing and renewal make it perhaps more modernist than postmodernist. It is Bret Easton Ellis's American Psycho (1991) that more powerfully deploys the blank, affectless mode of writing as a form of critique." (HARRISON, 2010, p. 55).
} 
of transgression" ". Silverblatt faz o uso do vocábulo "transgressivo" de forma pejorativa para descrever uma ficção que tem a violação - de normas e instituições sociais, bem como do próprio corpo - como tema principal. Ele ataca principalmente o Marquês de Sade, dizendo que é ele quem "oficializa a orgia americana". Além de Sade, Georges Bataille, Michel Foucault, Dennis Cooper, Bret Easton Ellis e vários outros também são criticados. A reportagem não é a primeira - e muito menos a última - a atacar obras transgressivas. O que a destaca das outras é o fato de Silverblatt ter sido o suposto cunhador do termo "transgressive fiction", que passou a ser usado para definir as obras desse grupo de escritores já citados e de outros que estão por vir.

Ainda em 1993 o escocês Irvine Welsh lança seu primeiro livro, Trainspotting, obra de impacto na ficção transgressiva. A princípio o livro não teve a melhor das recepções: chegou a ser considerado para o Man Booker Prize de $1993^{12}$, mas foi logo descartado por o julgarem ofensivo. Fora as temáticas já polêmicas de sexo, vício em heroína e periferia escocesa, o livro ainda é uma transcrição do dialeto de Glasgow, variando com inglês escocês e britânico, o que o torna um desafio de leitura e transgressivo do ponto de vista linguístico. Para ilustrar, segue um trecho do início do livro:

The sweat wis lashing oafay Sick Boy; he wis trembling. Ah wis jist sitting thair, focusing oan the telly, tryin no tae notice the cunt. He wis bringing me doon. Ah tried tae keep ma attention oan the Jean-Claude Van Damme video.

As happens in such movies, they started oaf wi an obligatory dramatic opening. Then the next phase ay the picture involved building up the tension through introducing the dastardly villain and sticking the weak plot thegither. Any minute now though, auld Jean-Claude's ready tae git doon tae some serious swedgin. (WELSH, 1993, p. 3).

No entanto, foi somente a adaptação para o cinema, de 1996, estrelando Ewan McGregor, com direção de Danny Boyle que lhe concedeu fama internacional e o status de obra cult. E é na trilha do sucesso da adaptação de Trainspotting que o autor com o qual escolhemos trabalhar consegue publicar, ainda em 1996, depois de inúmeras rejeições, sua primeira obra. Trata-se de Chuck Palahniuk e o polêmico Fight club.

\footnotetext{
${ }^{11}$ Em tradução livre, "Atração de impacto: quem são esses autores e por que querem nos ferir?: a nova ficção de transgressão". Disponível em: http://articles.latimes.com/1993-08-01/books/bk-21466_1_youngwriters. Acesso em agosto de 2015.

${ }^{12}$ Cabe ressaltar que o vencedor do Man Booker Prize 2015 foi o jamaicano Marlon James, com a obra $A$ brief history of seven killings, que, sob o pretexto de retratar a tentativa de assassinato do cantor Bob Marley, explora o contexto de violência da Jamaica entre as décadas de 1970 e 1990. O livro se destaca por seu caráter transgressivo, com linguagem forte, imagens grotescas e uma narrativa cacofônica de povos marginalizados, o que indica uma grande mudança de atitude do comitê de jurados frente a obras dessa natureza, visto que em 1993 desconsideraram Trainspotting pelos mesmos motivos que tornaram A brief history of seven killings vencedor.
} 


\section{$1.3 \mathrm{O}$ autor e a obra}

\subsubsection{O autor}

"O autor de Clube da luta". É assim que costumamos nos referir ao norteamericano Chuck Palahniuk, conhecido, ainda hoje, por seu primeiro romance publicado. Há de se pensar, ao considerar a grande maioria de artigos acadêmicos escritos a seu respeito, que o escritor publicou poucos textos desde Fight club (1996). Tal suposição está bem distante da realidade: Palahniuk contabiliza atualmente duas obras de não ficção, quinze romances, uma coletânea de contos, uma série de quadrinhos de dez volumes (sequência para o aclamado Fight club) e um livro de colorir para adultos. Considerando que a vida pessoal do autor lhe serve de inspiração para sua narrativa, segue uma breve biografia.

Charles Michael Palahniuk nasceu em Pasco, Washington, em 21 de fevereiro de 1962. Membro de uma família economicamente desprivilegiada, passou boa parte de sua infância morando em uma casa móvel (uma espécie de casa sobre rodas, como um trailer, porém maior) próximo a Burbank, Washington. Seus pais, Fred e Carol, divorciaram-se quando Palahniuk era adolescente, o que ocasionou sua mudança, juntamente com seus irmãos, para o rancho de sua avó materna. Palahniuk nunca chegou a conhecer os avós paternos, por conta da primeira em uma série de tragédias a marcar a família: Nick, o avô, atirou em sua esposa Paula durante uma briga e depois se matou, enquanto o filho, Fred, assistia a tudo de seu esconderijo debaixo da cama ${ }^{13}$. Em todo caso, foram os avós paternos que originaram o sobrenome incomum. Imigrantes ucranianos, quando chegaram aos Estados Unidos, Paula e Nick eram chamados apenas pelos primeiros nomes, o que no fim resultou em um sobrenome formado pela combinação dos dois, mantendo a pronúncia original: Paula + Nick = "Paul-ah-nick".

Ele estudou Jornalismo na Universidade de Oregon, concluindo seu bacharelado em 1986. Após a faculdade, Palahniuk trabalhou em uma estação de rádio em Eugene, Oregon, e passou a escrever para um jornal de Portland, Oregonian. Pouco tempo depois, entretanto, começou a trabalhar como mecânico em uma oficina, o que fez até sua carreira de escritor deslanchar. Durante esses anos, Palahniuk tentava levar a vida mais aventureira possível: vivia com pouco dinheiro, dividia apartamentos com amigos e estranhos, fazia viagens de carro sem destino certo, bebia muito, usava muitas drogas, lia muito e participava de um grupo chamado The Cacophony Society, dedicado a praticar

\footnotetext{
${ }^{13}$ Esse e outros episódios pouco convencionais de sua vida são narrados em suas duas obras de não-ficção Fugitives and refugees: a walk in Portland, Oregon (2003) e Stranger than fiction: true stories (2004).
} 
pegadinhas públicas em grande escala (uma inspiração confessa para o Project Mayhem de Fight club).

Além disso, foi nesse período que o futuro autor passou a dedicar parte de seu tempo ao trabalho voluntário, porém não apenas com o intuito de ajudar os mais necessitados, mas como forma de encarar seus próprios demônios. Em uma entrevista de 2005 para a versão online do jornal The Guardian ${ }^{14}$, Palahniuk contou ao jornalista Sean O'Hagan que tinha tanto medo de ficar sem dinheiro e virar um sem-teto que começou a trabalhar em um abrigo para moradores de rua, onde percebeu que a vida livre de amarras sociais não era de todo ruim. Seu medo da morte também foi confrontado com o voluntariado em um hospital para pacientes terminais, em que, ao lidar com a morte de perto, ele começou a encará-la com mais naturalidade.

No início de 1990, seguindo a indicação de um amigo, Palahniuk decidiu participar de um workshop de escrita criativa ministrado por Tom Spanbauer, guru do minimalismo e criador do "Dangerous Writing" ["Escrita perigosa", em tradução literal]. Como resultado do workshop, em agosto do mesmo ano, Palahniuk publicou um conto, "Negative Reinforcement", em um periódico literário da época chamado Modern Short Stories. Ainda durante o workshop, Palahniuk escreveu outros contos e os manuscritos de dois romances, que foram rejeitados por serem obscuros demais.

Sem se deixar abater pelas recusas, Palahniuk trabalhou em um novo manuscrito sobre uma modelo desfigurada e seu irmão transexual, no entanto, quando enviou às editoras, nenhuma delas o aceitou. Ele acreditava que a rejeição se devia ao tema arriscado de seu projeto - inicialmente intitulado Manifesto e que depois se tornaria Invisible Monsters, finalmente publicado em 1999 - e decidiu seguir seus instintos e, como forma de provocação, levar seu romance seguinte para um lado ainda mais obscuro.

Em uma tarde sem muito serviço na oficina em que trabalhava, Palahniuk escreveu um conto de sete páginas chamado Fight club. No posfácio da reedição de 2005 de seu então já famoso livro Fight club, o autor conta que se tratava de um experimento literário para passar o tempo em uma tarde entediante; sua intenção era escrever uma história que não precisasse descrever cada cena do percurso da personagem, que pudesse apenas "pular" e "cortar" para os momentos chave da trama, sem deixar de fazer sentido ou perder a atenção do leitor, estratégia que segue usando em todas as suas obras posteriores. O conto, segundo Palahniuk, foi a primeira história que conseguiu vender,

\footnotetext{
${ }^{14}$ Disponível em: https://www.theguardian.com/books/2005/may/08/fiction.chuckpalahniuk. Acesso em junho de 2016.
} 
publicada em uma antologia chamada The pursuit of happiness, e que mais tarde se tornaria o sexto capítulo do livro Fight club.

$\mathrm{O}$ autor levou três meses para redigir o primeiro rascunho da obra e em três dias conseguiu chamar a atenção de Gerry Howard, editor da W. W. Norton, que comprou o manuscrito pela pechincha de seis mil dólares. Fight club foi publicado em 1996 e ganhou o Pacific Northwest Bookseller's Association Award de 1997 e o Oregon Book Award for Best Novel, também de 1997. Sua recepção, a princípio, não foi muito positiva: críticos e leitores viam na obra apenas violência gratuita e niilismo, e mesmo a adaptação para o cinema de 1999, com direção de David Fincher e estrelando Brad Pitt, Edward Norton e Helena Bohan Carter, não obteve sucesso imediato - o orçamento de 63 milhões de dólares rendeu apenas 37 milhões de bilheteria. Foi apenas com o lançamento do DVD duplo, ainda em 1999, que o filme caiu nas graças dos críticos e do público geral, o que logo trouxe a atenção para a obra literária que o inspirou. Até hoje Fight club é considerado um dos melhores filmes de todos os tempos, como aponta a lista da revista Empire, de 2008, que coloca o filme na décima posição entre os 500 melhores ${ }^{15}$ e a lista de 25 melhores filmes cult de todos os tempos da revista RollingStone, de 2014, que o ranqueia na $16^{\mathrm{a}}$ posição ${ }^{16}$.

No mesmo ano do lançamento do filme que lhe traria fama, Palahniuk passou por outro momento trágico: seu pai, Fred, e sua namorada foram assassinados pelo ex-marido da moça. Palahniuk entrou na justiça com um pedido de pena de morte para Dale Shackelford, o autor do crime, que foi declarado culpado e sentenciado em 2001. Os longos momentos que Palahniuk passou brigando na justiça, bem como a superação emocional da morte violenta de seu pai, levaram-no a escrever Lullaby (2002). Isso serve para mostrar que, apesar de satíricos e exagerados, os temas e episódios de suas obras são, em geral, baseados em acontecimentos reais. Ainda no posfácio de Fight club, o autor conta que cada história que já ouviu de seus amigos acaba sendo escrita e admite que mesmo o que ele inventa não é novidade alguma, pois "não há nada que possamos imaginar que um milhão de pessoas já não estejam fazendo" (2005, p. 215).

\footnotetext{
${ }^{15}$ Disponível em: http://www.empireonline.com/movies/features/500-greatest-movies/. Acesso em janeiro de 2017. A título de curiosidade, na mesma lista a adaptação cinematográfica de $A$ clockwork orange ocupa a $36^{\mathrm{a}}$ posição, a de Trainspotting ocupa a $316^{\mathrm{a}}$ e a de American Psycho, $435^{\mathrm{a}}$.

16 Disponível em: http://www.rollingstone.com/movies/pictures/readers-poll-the-25-best-cult-movies-ofall-time-20140507/16-fight-club-0609837. Acesso em janeiro de 2017.
} 
Além do que ele e os amigos vivem, Palahniuk também faz muita pesquisa para escrever seus textos. Em uma reportagem para a versão online do jornal The Telegraph, de 2003, William Leith entrevistou Chuck Palahniuk e escreveu:

Como pesquisa para suas histórias, ele lê, mas, acima de tudo, conversa com
pessoas. "Eu vou para qualquer lugar onde as pessoas contam histórias", diz
ele. "Grupos de apoio, grupos de superação. Chats de telesexo são uma fonte
incrível de pesquisa. Em Invisible monsters, eu tinha uma cena onde a
personagem precisava mostrar para os pais que sabia mais sobre práticas
sexuais bizarras do que eles pensavam, e logo eu precisava saber mais sobre
práticas sexuais muito bizarras. Então eu liguei para um número de telesexo e
disse 'Beleza, me conte o pior'. E um monte pessoas excitadas apareceram". ${ }^{17}$

Acusado de ser anarquista e niilista por muitos de seus críticos e leitores, tanto pelas temáticas quanto pelos experimentos com estruturas narrativas, Palahniuk defendese dizendo que seu único objetivo é escrever sobre as parcelas da sociedade e acontecimentos cotidianos geralmente ignorados pela literatura. Ainda na entrevista de 2005 para o The Guardian"18, ele diz: "Meus livros são sempre sobre alguém tirado de um estado de solidão e isolamento e inserido na comunidade. Pode ser uma comunidade degenerada, suja e pobre, mas eles não estão mais sozinhos. [...] Não escrevo nada [...] além de romances contemporâneos”. Para ele, a escrita é uma forma de lidar com a dor, seja sua ou dos outros, e de superar os infortúnios da vida sem enlouquecer.

Considerando essa afirmação de que seus textos não são mais do que romances modernos, com personagens marginais buscando uma conexão, um pertencimento no meio em que vivem, é possível traçar um paralelo com o carnaval de Bakhtin. Como Bakhtin afirma em A cultura popular na Idade Média e no Renascimento:

Ao contrário da festa oficial, o carnaval era o triunfo de uma espécie de
liberação temporária da verdade dominante e do regime vigente, de abolição
provisória de todas as relações hierárquicas, privilégios, regras e tabus. Era a
autêntica festa do tempo, a do futuro, das alternâncias e renovações. [...] A
abolição das relações hierárquicas possuía uma significação muito especial.
Nas festas oficiais, com efeito, as distinções hierárquicas destacavam-se
intencionalmente [...]. Essa festa tinha por finalidade a consagração da
desigualdade, ao contrário do carnaval, em que todos eram iguais e onde
reinava uma forma especial de contato livre e familiar entre indivíduos
normalmente separados na vida cotidiana pelas barreiras intransponíveis da

17 'To research his stories, he reads, but mostly talks to people. 'I go any place people tell stories,' he says. 'Support groups, 12-step groups. Phone-sex chat lines are an incredible place to do research. In Invisible Monsters, I had a scene where a character had to let her parents know that she knew a great deal more about bizarre sex acts than they probably realised, and I needed to know about really bizarre sex acts. So I just got on a phone-sex hotline and said, 'OK, let me hear the worst.' And all these horny people came on."' Disponível em: http://www.telegraph.co.uk/culture/books/3604888/A-writers-life-Chuck-Palahniuk.html. Acesso em junho de 2016.

18 "My books are always about somebody who is taken from aloneness and isolation - often elevated loneliness - to community. It may be a denigrated community that is filthy and poor, but they are not alone [...]. I write nothing [..] but contemporary romances". Disponível em: https://www.theguardian.com/books/2005/may/08/fiction.chuckpalahniuk. Acesso em junho de 2016. 
sua condição, sua fortuna, seu emprego, idade e situação familiar. (BAKHTIN, 1999, p. 8 e 9).

Pode-se entender, portanto, que a rejeição dos padrões impostos, desrespeito pelas leis, autoridades e instituições de poder, quebra de paradigma e tabus e exposição satírica do grotesco, do feio e do rude que é central em todas as obras do autor seria uma tentativa das personagens de sair (e tirar quantas pessoas conseguir) dessa caixinha de normas e expectativas sociais para tornar possível esse contato livre, para se aproximar de outros indivíduos e se sentir parte de um coletivo.

Jesse Kavadlo inicia seu artigo The fiction of self-destruction: Chuck Palahniuk, closet moralist (2005) dizendo:

Imagine como é esfregar seus olhos com vidro quebrado até que fiquem em carne viva. Essa é a sensação de ler Chuck Palahniuk. Sim, você sente os cacos nos olhos e depois você é socado, com força, seu nariz está quebrado. Como se o mundo estivesse quebrado. [...] Primeiro, seus olhos são esfregados com vidro quebrado, depois com sangue e linfa, e você quer mais. Esse é só o enredo. Nem me peça para falar das personagens. Você devia parar de ouvir agora mesmo. [...] Mas de alguma forma, você continua lendo. E depois de limpar o estrago dos olhos, você percebe uma coisa. Que o mundo não está quebrado. De alguma forma, o mundo parece mais inteiro do que antes de você começar. Essa é a sensação de ler Chuck Palahniuk. Quebrado, mas algo perturbador e belo é recriado em seu lugar. E quando você termina, você percebe que está tudo bem. Quando você termina, você se pega pensando nos livros. E, talvez, se tiver sorte, soando como eles. (KAVADLO, 2005, p. 3. Tradução nossa.) ${ }^{19}$.

$\mathrm{O}$ autor defende que, por trás de todo o surrealismo violento, suspense noir e reviravoltas psicológicas e narrativas, o objetivo central da obra de Palahniuk é a redenção das personagens marginalizadas pelo amor e esperança, a constante tentativa de criar algo real em um mundo onde tudo é a "cópia de uma cópia de uma cópia", como o narrador de Fight club mesmo descreve (PALAHNIUK, 1996, p. 21). Chuck Palahniuk seria, portanto, um "moralista enrustido" [“closet moralist"], escondendo nas entrelinhas de textos que tendem a subverter padrões sociais e literários para "ofender a direita com anticonsumismo, clichês contra a família tradicional, sexo e violência e alienar a esquerda

\footnotetext{
19 "Imagine what it's like to have your eyes rubbed raw with broken glass. This is what reading Chuck Palahniuk is like. You feel the shards in your eyes, yes, and then you're being punched, hard, your nose broken. Like the world is broken. [...] Eyes rubbed in broken glass, first, then in blood and lymph, and you want more. That's just the plot. Don't even get me started on the characters. You should stop listening right now. [...]But, somehow, you keep reading. And after you wipe the pulp from your eyes, you realize something. That the world is not broken. Somehow, the world feels more together than before you started. This is what it feels like to read Chuck Palahniuk. Broken, but something disturbing and beautiful recreated in its place. And when you're done, you realize that everything really is all right. When you're done, you find yourself thinking about the books. And, maybe, if you're lucky, sounding like them." (KEVADLO, 2005, p. 3).
} 
com uma possível misoginia e inclinações fascistas", um desejo romântico por conexão humana (KAVADLO, 2005, p. 6).

O comportamento autodestrutivo das personagens implica sempre a destruição daquilo que aparentam defender. Em Fight club, por exemplo, Tyler Durden, a outra personalidade rebelde do narrador, defende incansavelmente que o indivíduo só pode ser espiritualmente salvo através da autodestruição violenta encontrada no clube da luta, que o único modo de escapar da sociedade de consumo que te faz trabalhar em empregos que você odeia para comprar coisas que não precisa é a destruição das instituições de poder e seus monumentos, mas, no fim, o narrador percebe que Tyler substituiu a ditatura do consumo por uma ditadura do anticonsumo, que seus ideais são loucos e perigosos e acaba matando Tyler. Sua redenção se dá através do sentimento romântico que nutre por Marla Singer e é sua conexão com ela que o salva. Kavadlo acredita que na ironia dramática de Palahniuk, na exaltação da masculinidade, do sexo, da individualidade e do caos, o leitor tem, na verdade, "a oportunidade de sentir os poderes de redenção do feminismo, do amor, da cooperação, da harmonia e da narração ao habitar mundos onde eles são visivelmente, e até absurdamente, inexistentes"; a personificação do masculino esconde uma crítica feminista e o existencialismo exterior esconde o sentimentalismo interior (KAVADLO, 2005, p. 7. Tradução nossa) ${ }^{20}$.

Como consequência de sua temática e estética narrativa, Palahniuk é imediatamente classificado como autor transgressivo e, dentro do gênero, é um dos nomes mais proeminentes. Quando questionado quanto ao rótulo, em uma entrevista concedida a Lisa Morton para a revista Nightmare, em fevereiro de 2015, porém, a resposta do autor foi:

Eu nunca tinha ouvido falar no termo até que o vi dentro do Fight club; o Fight club é listado na Biblioteca do Congresso como "literatura transgressiva". É um rótulo que meu editor tinha dado a ele porque ele tinha editado o Bret Easton Ellis e tinha editado o Irvine Welsh - esses outros autores que ele claramente via como "transgressivos", e daí ele me classificou como transgressivo. Mas... cara, eu não acho que seja o caso, mas não consigo pensar em uma classificação melhor, então tenho que deixar como está. ${ }^{21}$

\footnotetext{
20 "[...] readers have the opportunity to feel the redemptive powers of feminism, love, cooperation, harmony, and story telling, by inhabiting worlds where they are conspicuously, even absurdly, absent." (KAVADLO, 2005, p. 7).

21 "I had never heard the term until I saw it inside Fight Club; Fight Club is listed in the Library of congress under "transgressive literature." It's a label that my editor had put on it, because he had edited Bret Easton Ellis, and he'd edited Irvine Welsh — these other writers that he clearly saw as "transgressive," and so he'd labeled me as transgressive. But . . . boy, I don't think it's the case, but I can't think of a better label, so I have to let it stand." Disponível em: http://www.nightmare-magazine.com/nonfiction/interview-chuckpalahniuk/. Acesso em fevereiro de 2017.
} 
Independente da classificação que o autor daria à sua obra, fato é que as características transgressivas, conforme já delineamos anteriormente, estão presentes em sua narrativa de forma marcante e incontestável. A obra de Chuck Palahniuk, atualmente, é extensa e bastante variada; o autor experimenta com gêneros e estruturas narrativas diversas em seus textos e tem conseguido publicar quase um livro seu por ano, como mostra a tabela a seguir:

\begin{tabular}{ll} 
Ano & Obra \\
1996 & Fight club \\
1999 & Survivor \\
1999 & Invisible monsters \\
2001 & Choke \\
2002 & Lullaby \\
2003 & Fugitives and refugees: a walk in Portland, \\
& Oregon \\
2003 & Diary \\
2004 & Stranger than fiction: true stories \\
2005 & Haunted \\
2007 & Rant \\
2008 & Snuff \\
2009 & Pygmy \\
2010 & Tell-All \\
2011 & Damned \\
2012 & Invisible monsters remix \\
2013 & Doomed \\
2014 & Beautiful you \\
2015 & Make something up: stories you can't \\
& unread \\
\hline & Fight club \\
& \\
&
\end{tabular}

2015 Fight club 2

2016 Bait: Off-Color Stories for You to Color

\section{Gênero}

Ficção/Romance

Ficção/Romance

Ficção/Romance

Ficção/Romance

Ficção/Romance

Não ficção/Romance

Ficção/Romance

Não ficção/Romance

Ficção/Romance

Ficção/Romance

Ficção/Romance

Ficção/Romance

Ficção/Romance

Ficção/Romance

Ficção/Romance

Ficção/Romance

Ficção/Romance

Ficção/Coletânea de contos

Ficção/Romance gráfico

Ficção/Livro de colorir

No Brasil, Palahniuk chegou pela primeira vez às mãos dos leitores em 2000, com a tradução de Fight club feita por Vera Caputo, publicada pela Nova Alexandria. Além 
de Clube da luta, a editora também publicou Sobrevivente (Survivor) em 2003. Atualmente, doze de seus dezenove livros contam com tradução para o português e três já foram, inclusive, retraduzidos, conforme mostra a tabela abaixo:

\begin{tabular}{|c|c|c|c|}
\hline Título traduzido & Ano de publicação & Tradutor(a) & Editora \\
\hline Clube da luta & 2000 & Vera Caputo & Nova Alexandria \\
\hline Sobrevivente & 2003 & $\begin{array}{l}\text { Marcelo Oliveira } \\
\text { Nunes }\end{array}$ & Nova Alexandria \\
\hline Cantiga de ninar & 2004 & Paulo Reis & Rocco \\
\hline No sufoco & 2005 & $\begin{array}{l}\text { Paulo Reis e Sérgio } \\
\text { Moraes Rego }\end{array}$ & Rocco \\
\hline Diário & 2007 & Ryta Vinagre & Rocco \\
\hline Assombro & 2007 & Paulo Reis & Rocco \\
\hline Monstros invisíveis & 2009 & $\begin{array}{l}\text { Paulo Reis e Sérgio } \\
\text { Moraes Rego }\end{array}$ & Rocco \\
\hline Snuff & 2010 & Paulo Reis & Rocco \\
\hline $\begin{array}{l}\text { Mais estranho que } \\
\text { a ficção }\end{array}$ & 2011 & Alyda Sauer & Rocco \\
\hline Clube da luta & 2012 & Cassius Medauar & Leya \\
\hline Sobrevivente & 2012 & Tatiana Leão & Leya \\
\hline Condenada & 2013 & Santiago Nazarian & Leya \\
\hline Condenada & 2014 & Tatiana Leão & Leya \\
\hline Maldita & 2014 & Érico Assis & Leya \\
\hline No sufoco & 2015 & Érico Assis & Leya \\
\hline Clímax & 2015 & Érico Assis & Leya \\
\hline $\begin{array}{l}\text { Assombro: um } \\
\text { romance de } \\
\text { histórias }\end{array}$ & 2016 & Érico Assis & Leya \\
\hline Clube da luta 2 & 2016 & Érico Assis & Leya \\
\hline
\end{tabular}

Dentre todos os tradutores das obras Palahniuk no Brasil, dois se destacam pela quantidade de traduções feitas: Paulo Reis, com cinco traduções para a Rocco, e Érico Assis, também com cinco traduções para a Leya até o momento. Em duas das obras, o trabalho de Paulo Reis aparece como tendo sido feito em parceria com Sérgio Moraes Rego, no entanto, pesquisando os nomes dos dois tradutores, somos levados a crer que se trata de uma pessoa só: Paulo Sérgio Moraes Rego Reis. 
Paulo Sérgio Moraes Rego Reis, segundo a biografia da Enciclopédia Itaú Cultural $^{22}$, nascido em 1952, é um ator e diretor carioca que se destacou nos anos 80 ao dirigir espetáculos do Pessoal do Despertar, grupo que fundou com a atriz Maria Padilha. Ao longo dos anos ele esteve envolvido em diversos projetos cênicos, com textos clássicos que variavam desde $O$ despertar da primavera, de Frank Wedekind, que montou com Maria Padilha e Miguel Falabella em 1979, a Julius Cesar, de William Shakespeare, na qual participou como assistente de direção de Ron Daniels na montagem de 1983 da Royal Shakespeare Company.

Em 1988, atingiu fama nacional ao interpretar o personagem Olavo da novela Vale tudo, da Rede Globo. Em uma entrevista para o site Extra, de junho de $2011^{23}$, ele conta que por conta de sua ingenuidade, acabou revelando o final da novela em uma entrevista para uma amiga e ficou com fama de mau caráter no meio artístico, tendo que batalhar muito depois disso para que sua carreira de ator não tivesse fim. Mesmo com esse episódio, que fez com que não conseguisse mais grandes papeis na televisão, Reis conta com uma lista de mais de 60 trabalhos como ator e diretor para a TV, cinema e teatro.

É curioso ver que em todas as reportagens que elogiam sua atuação no universo cênico ou promovem suas peças mais recentes, seu trabalho como tradutor nunca é mencionado. Na verdade, quase não há informação alguma sobre suas traduções e a única ligação que temos entre o Paulo Reis tradutor de Nick Hornby, Irvine Welsh, Chuck Palahniuk e David Ebershoff e o Paulo Reis de Vamp, Rainha da sucata e Os dez mandamentos é uma matéria da edição online da revista Época, escrito por Joana Monteleone em 2010. No texto, intitulado "O sentido da palavra", a autora fala dos erros e acertos dos tradutores e do mercado de traduções no Brasil, em constante crescimento, mencionando tradutores como Boris Schnaiderman, José Paulo Paes e os irmãos Campos. Paulo Reis é mencionado do trecho:

"O importante é conhecer as equivalências culturais entre as línguas", diz
Paulo Reis, tradutor elogiado dos três livros do inglês Nick Hornby, Alta
Fidelidade, Um Grande Garoto e Fome de Bola. Reis, ator de televisão e
diretor de teatro, resolveu pôr em prática as habilidades com a língua que
adquiriu nos anos em que morou na Inglaterra. Começou a carreira fazendo um
teste na editora Rocco. Saiu-se tão bem que acabou escolhido para cuidar de
vários títulos. ${ }^{24}$

22 Disponível em: http://enciclopedia.itaucultural.org.br/pessoa19451/paulo-reis. Acesso em novembro de 2016.

23 Disponível em: http://extra.globo.com/famosos/eu-nao-parei-de-trabalhar-parei-de-aparecer-revelapaulo-reis-olavo-de-vale-tudo-23-anos-depois-de-novela-ir-ao-ar-2106828.html. Acesso em novembro de 2016.

$24 \quad$ Disponível em: http://revistaepoca.globo.com/Revista/Epoca/0,_EMI151987-15220,00O+SENTIDO+DA+PALAVRA.html. Acesso em novembro de 2016. 
E de vários títulos ele cuida até hoje. Recentemente, foi lançada, na edição de 2016 da FLIP (Festa Literária Internacional de Paraty), a tradução de Paulo Reis da obra The sex life of siamese twins (2014), de Irvine Welsh, com o título A vida sexual das gêmeas siamesas (2016, Rocco), que contou, inclusive, com a presença do autor escocês no evento. Isso mostra que Paulo Reis continua ativo em suas traduções, seja como Paulo Reis, como Paulo Sérgio Moraes Rego Reis, Sérgio Moraes Rego ou como a dupla Paulo Reis e Sérgio Moraes Rego, ainda que não possamos desvendar o motivo de tamanha variação de nomes.

O outro tradutor que tem trabalhado constantemente com as obras de Chuck Palahniuk é Érico Assis. Diferentemente do caso de Paulo Reis, sobre as traduções de Assis há inúmeras informações, de diversas fontes, seja em seu próprio site profissional, entrevistas para sites, jornais, revistas, artigos acadêmicos publicados por ele ou nos quais é mencionado etc. Ele possui título de bacharel em Jornalismo e em Publicidade e Propaganda, ambos pela Universidade Católica de Pelotas (1998-2002), mestrado em Ciências da Comunicação pela Universidade do Vale do Rio dos Sinos (2004-2006) e é doutorando no Programa de Pós-graduação em Estudos da Tradução da Universidade Federal de Santa Catarina (2014-atualmente), sob orientação do Prof. Dr. Ronaldo Lima, onde estuda a tradução de quadrinhos.

Iniciou sua carreira de tradutor em 2008, com publicações a partir de 2009, e desde então tem atuado de forma bastante prolífica na área. É possível ver a dimensão de seu trabalho em sua página ericoassis.com.br, onde ele faz a seguinte apresentação:

\footnotetext{
Sou tradutor inglês - português desde 2008. Trabalho como free-lancer para o mercado editorial. Traduzo sobretudo histórias em quadrinhos, não-ficção e literatura infantil. Já traduzi aproximadamente 200 publicações.

Traduzo com regularidade para as editoras Companhia das Letras, Panini e Marsupial. Já colaborei e colaboro esporadicamente com as editoras LeYa, Cosac/Naify, DCL, Globo, Intrínseca, Pulo do Gato, Saraiva, Devir e WMF/Martins Fontes. Também prestei serviços de tradução a autores independentes. $^{25}$
}

Em entrevista para o site Pipoca e Nanquim, de fevereiro de 2012, Assis conta que sempre quis ser tradutor, não apenas de quadrinhos, mas de literatura. Como jornalista, escreveu para o site Omelete por mais de dez anos (e ainda colabora eventualmente), e foi por meio de seu trabalho com HQs lá que conheceu André Conti, editor responsável pela criação do selo Quadrinhos e Cia., da Companhia das Letras. Nas palavras do próprio Assis:

\footnotetext{
${ }^{25}$ Disponível em: http://ericoassis.com.br/. Acesso em novembro de 2016.
} 
Quando o André Conti estava montando o selo Quadrinhos na Cia. na Companhia das Letras, entrou em contato comigo para trocar idéias. Mencionei que estava a fim de traduzir e ele me passou um teste. Passei, e a primeira tradução acabou sendo Retalhos, do Craig Thompson.

A partir daí, vieram convite da Panini - depois de anos que passei enchendo o saco do Fabiano* pedindo um teste -, da Saraiva, da Barba Negra, da Globo. Por enquanto tem sido muito legal. ${ }^{26}$

Quatro de suas traduções já foram selecionadas para premiação pela Fundação Nacional do Livro Infantil e Juvenil com o Selo Altamente Recomendável na categoria Tradução/Adaptação:

- O muro, de Peter Sís (Companhia das Letras, 2013);

- Contos de lugares distantes, de Shaun Tan (Cosac/Naify, 2013);

- A coisa terrível que aconteceu com Barnaby Brocket, de John Boyne (Companhia das Letrinhas, 2014);

- A conferência dos pássaros, de Peter Sís (Companhia das Letrinhas, 2014).

Hoje em dia, mantém um site chamado A pilha, onde escreve sobre as histórias em quadrinhos que "lê, traduz, compra e empilha"27, e é colunista do blog da Companhia das Letras, com contribuições mensais que já somam 123 textos ${ }^{28}$.

\subsubsection{A obra}

Para o trabalho, selecionamos uma publicação mais recente do autor, Make something up: stories you can't unread, lançada em 26 de maio de 2015. Trata-se de uma coletânea que reúne 22 contos e 1 novela, escritas ao longo de vários anos, alguns já publicados anteriormente em sites e revistas, outros inéditos. As histórias apresentam inúmeras variações de estilo, recursos linguísticos e literários, enredos, temas etc. Entre elas, há, por exemplo, o conto do adolescente que faz experiências de contaminação com HPV no próprio pênis em "The toad prince". Uma série de adolescentes com futuros promissores que decidem fritar o próprio cérebro com desfibriladores em “Zombies". Um conto escrito na forma de um informe oficial de condomínio em "Liturgy". Um campo de concentração para a cura gay de garotos que, no fim das contas, são heterossexuais tentando roubar dinheiro dos pais em "Inclinations". Três histórias com pretensões de fábula, conectadas entre si, que lidam com temas como o lugar injusto da mulher no mercado de trabalho ("How Monckey got married, bought a house and found happiness

\footnotetext{
26 Disponível em: http://pipocaenanquim.com.br/destaques/minha-estante-33-erico-assis/. Acesso em novembro de 2016.

${ }^{27}$ Disponível em: http://apilha.com.br/sobre/. Acesso em novembro de 2016.

${ }^{28}$ Disponíveis em: http://historico.blogdacompanhia.com.br/category/colunistas/erico-assis/. Acesso em novembro de 2016.
} 
in Orlando"), adultério e prostituição ("Why Coyote never had Money for parking") e bullying nas escolas ("Why Aadvark never landed on the moon").

Vemos nos textos a presença constante de temas incômodos, que pretendem tirar o leitor de sua zona de conforto: sexo, sexualidade, morte, escatologia, fluidos corporais, deformações físicas, religião, racismo, xenofobia, entre muitos outros comuns à ficção transgressiva. Isso para atacar, principalmente, a sociedade capitalista, a geração criada pela televisão, por instituições histórico-culturais que estabelecem padrões de beleza, de vida, de sucesso. O corpo, o prazer carnal e a sexualidade, por serem tratados pelos sistemas de crença como entidades intocáveis, pecaminosas, que não se devem mencionar, são abordados com frequência no texto transgressivo, que pretende, por meio da ironia, alegorias, exagero ou justaposição da linguagem, lutar contra essa repressão. A obsessão com a morte também é comum no anti-herói transgressivo, que tenta desligarse da idealização popular que tem na negação da morte e na busca por uma existência além-túmulo a base de sua consciência de massa. Isso ilustra uma tentativa dos autores desse gênero de atribuírem caráter crítico às obras, torna-las agentes sociais, revolucionárias, até certo ponto, através da transgressão. Ao mesmo tempo, também é possível identificar em cada um dos contos a busca pela conexão humana e pertencimento que mencionamos anteriormente; se cada vez mais Palahniuk deseja causar impacto e experimentar com novos estilos e narrativas, parece permanecer fiel as noções românticas de personagens que só querem encontrar seu lugar no mundo.

Assim como acontece com todo material de autoria de Chuck Palahniuk, a resposta crítica de Make something up divide-se entre elogios e depreciação. Mesmo as resenhas mais negativas, porém, não desmerecem a coletânea como um todo, admitindo o brilhantismo de alguns contos e deixando claro que, mesmo em seus piores momentos, sua narrativa é cativante e poderosa.

Sandra Newman, em sua resenha para a versão online do jornal The Guardian, critica o mau uso que Palahniuk faz de seu talento narrativo, desperdiçando-o com histórias sobre urina e circuncisão. Entretanto, ela afirma que

Até as piores histórias em Make Something Up têm sua parcela de poder - e algumas são tão ruins que as ler em voz alta poderia fazer moscas caírem duras no chão. [...] Mas nas melhores histórias, um conjunto de excentricidade, horror e sentimentos te leva além da descrença para dentro de um espaço habitado por boas histórias em quadrinhos ou autores como Rabelais e Burroughs. ${ }^{29}$ (Tradução nossa).

\footnotetext{
29 "Even the worst stories in Make Something Up have their share of this power - and some are so bad that reading them aloud could make flies fall dead from the air. [...] But in the best stories, a conjunction of zaniness, horror and sentiment propels you beyond disbelief into the space inhabited by good comic books,
} 
Para exemplificar melhor como funcionam a transgressão e a crítica social em seus textos, apresentamos um breve resumo e análise dos quatro contos da coletânea que selecionamos para tradução.

\subsubsection{Knock-knock}

"Knock-knock" é o conto que abre a coletânea. Nele temos a história do personagem sem nome, como é comum nos textos de Chuck Palahniuk, cujo pai se encontra à beira da morte com um tumor no cérebro. O pai, que o narrador chama apenas de "my old man", era um notório contador de piadas, passando as tardes de sábado na barbearia apenas pelo prazer de entreter os frequentadores. Ao longo de sua infância e adolescência, o garoto aprendeu a reproduzir as piadas que o pai contava mesmo sem saber o que significavam, assim como aprendeu a rir de todas elas como forma de demonstrar seu afeto e respeito por ele.

No momento em que seu pai é diagnosticado com câncer e está prestes a morrer em um hospital para doentes terminais, o narrador inspira-se no filme Patch Adams: $o$ amor é contagioso, com Robin Williams, que é supostamente baseado em fatos reais, e em relatos de pacientes que se curaram de doenças terminais com a terapia do riso, para tentar reverter o quadro de seu pai à base de gargalhadas. No entanto, ele conta as piadas que seu pai lhe ensinou e que costumava achar muita graça, mas não consegue arrancar sequer um sorriso. Ao fim do conto, em um momento de desespero, histeria e epifania, o narrador vai percebendo que elas nunca foram de fato engraçadas, que a piada, na verdade, era ele.

Apesar das piadas incômodas e altamente preconceituosas, o texto consegue ser muito delicado, retratando uma relação entre pai e filho e passando muito claramente a dor e desespero do narrador ao ver a vida de seu pai se esvaindo. Rir daquelas piadas era sua forma de se conectar com seu pai, sua única família, uma vez que fora abandonado pela mãe aos quatro anos de idade, e em momento algum ele para para refletir sobre elas. Apenas em uma circunstância trágica, em que o pai deixa de achar graça de suas piadas, o narrador cai em si. Contar as piadas para salvar o pai é sua tentativa de manter viva a única conexão humana que conhece e que o separa de uma vida solitária, em um mundo para o qual ele não se sente preparado (“[...] o coroa tá me deixando pra trás sem saber a

or by authors such as Rabelais and Burroughs". Disponível em < http://www.theguardian.com/books/2015/jun/10/make-something-up-chuck-palahniuk-review-shortstory-collection>. Acesso em outubro de 2015. 
resposta pra nada. Ele tá me abandonando enquanto eu ainda sou um estúpido de merda" (PALAHNIUK, 2015, p. 7. Tradução nossa.) ${ }^{30}$ ).

Em momento algum o conto repleto de piadas é engraçado. Muito pelo contrário, ele nem tenta ser e o autor explora o preconceito absurdo e de péssimo gosto das piadas para causar incômodo e ultraje no leitor, e talvez como forma de revelar um pouco mais sobre esse pai de quem se sabe tão pouco. Não fica claro como exatamente é a relação entre pai e filho, mas parece certo afirmar que não são amigos ou confidentes, que o narrador não admira o pai, mas o ama porque "depois que cê nasce, não é como se tivesse escolha" (PALAHNIUK, 2015, p. 3. Tradução nossa.) ${ }^{31}$.

Sabemos que o pai é um sujeito que acha graça e reproduz repetidamente piadas politicamente incorretas, além de ensina-las ao filho; soma-se a isso o fato de ele ensinar ao garoto uma série de outras coisas suspeitas (cavar um buraco, apertar um gatilho e tirar manchas de sangue parece uma sequência homicida) e o abandono da mãe (o que levaria essa mãe a abandonar o marido e o filho pequeno? Algum tipo de relação abusiva?) e, de repente, o pai não é mais a imagem representativa do cidadão de bem. Além disso, o narrador também aparenta ter algum problema, seja psicológico, dificuldade de aprendizado ou outro, ele se mostra, além de muito ingênuo, ignorante a respeito de muitas coisas, como podemos ver pela forma como ele diz (ou não sabe dizer) "multiplecation tables" (p. 3), "end-orphans" e "oxy-generated blood” (p. 4), e pela forma histérica e irracional como ele lida com a situação, chegando (mas não se limitando) à cena em que joga a torta de merengue no rosto do pai moribundo, o que lhe rende uma visita à ala psiquiátrica do hospital.

É interessante notar, também, como o narrador alterna a voz do texto em primeira e terceira pessoa, por vezes iniciando uma parte de sua narrativa com um "daí o menino" como se estivesse começando a contar uma piada. Isso, intercalado com as piadas que ele de fato conta e que nunca arrancam risadas, seja do pai ou do leitor, demonstra uma tentativa de seguir os passos do pai e transformar tudo em uma grande piada, mesmo que ele tenha que se desculpar o tempo todo por não saber contar ou não ter senso de humor - o problema é com ele, pois se o pai achava engraçado é porque deve ser engraçado. $\mathrm{O}$ ritmo da narrativa também é interessante de se notar, pois ela começa calma, com um tom que beira a nostalgia, e conforme o narrador vai tentando salvar a vida do pai (e falha

\footnotetext{
30 “[...] the old man's leaving me not knowing the answer to anything. He's abandoning me while I'm still so fucking stupid." (PALAHNIUK, 2015, p. 7).

31 “[...] after you're born it's not like you get a choice." (PALAHNIUK, 2015, p. 3).
} 
repetidamente) a narrativa vai acelerando e se tornando cada vez mais claustrofóbica, e a mistura da tentativa de humor (que na verdade não é humor) com a dor da perda de um pai a quem o filho era tão clara e cegamente devoto, consegue despertar no leitor, ao mesmo tempo, emoção e extremo desconforto, e ambos os sentimentos perduram por um longo momento após o fim da leitura.

\subsubsection{How Monkey got married, bought a house and found happiness in Orlando}

O conto é o terceiro da obra, e o primeiro da série de fábulas contemporâneas que mencionamos acima. Ele é narrado na terceira pessoa, por um narrador omnisciente, diferente dos outros três contos traduzidos aqui, e conta a história de Macaca, uma jovem formada em Comunicação que começa a trabalhar como promotora de produtos-teste em uma indústria de alimentos. Arrogante, Macaca implora por desafios, quer ser testada, e seu chefe, Hamster, oferece à ela a chance de uma promoção se conseguir vender um queijo. Essa promoção é o sonho de Macaca, que poderia finalmente se estabelecer, comprar uma casa e formar família.

No entanto, o queijo tem o pior cheiro possível e nenhum animal quer se arriscar a chegar perto dele, quem dirá a comê-lo, e Macaca não consegue alavancar as vendas. Após ligar para seu supervisor direto e, mais tarde para um supervisor de nível ainda mais elevado, Macaca é desafiada a comer o queijo. Sentindo-se já derrotada, ela não tem nada a perder e come o queijo, descobrindo que, apesar do cheiro, ele tem o gosto mais incrível que jamais provou. Na mesma noite, os supervisores a contatam dizendo que o queijo será tirado de circulação, ao que ela luta com unhas e dentes para mantê-lo e no dia seguinte decide, por conta própria, ir promove-lo. Os animais no supermercado, porém, irritados com sua presença e com o queijo fedorento, avançam sobre ela, derrubando sua mesa, e Gorila, funcionário do estabelecimento, ao agarrá-la para jogá-la porta afora, acaba comendo um pedaço do queijo e compreendendo a devoção de macaca a ele. $\mathrm{O}$ conto acaba nesse momento, e recorremos ao título para saber que Macaca e Gorila se casaram, compraram uma casa e encontraram a felicidade juntos em Orlando.

Analisando o conto, e sabendo se tratar de uma fábula, conseguimos identificar uma possível moral da história: seja humilde, lição que Macaca aprende da maneira mais difícil para o seu ego, por meio da humilhação. Entretanto, como é de se esperar de um conto transgressivo, a moral fabulesca não é o objetivo central da narrativa, ficando, inclusive, escondida nas entrelinhas do texto. O conto, na verdade, levanta outras questões, como a do lugar injusto da mulher dentro do mercado de trabalho, as 
expectativas sociais às quais a mulher se submete (a necessidade de se estabelecer, casarse e formar família) e a objetificação do corpo feminino por uma instituição de poder no caso, a indústria alimentícia. Macaca é forçada a usar o próprio corpo para chamar atenção, promover e vender produtos, a oferecer seu pescoço para ser cheirado, usar uma roupa provocante para convencer clientes, jogar charme e paquerar. Isso é fruto de uma sociedade machista que sexualiza o corpo feminino em campanhas publicitárias, tratamno como objeto: a mulher é um produto, não um indivíduo. Percebemos que os dois animais que ocupam cargos de chefia na empresa são homens e adotam uma postura paternalista e condescendente em relação a ela, além do fato de o cargo de supervisão regional ser dado ao Coiote sem que Macaca fosse, de fato, considerada para a vaga.

Macaca se submete a tal objetificação na esperança de conseguir uma posição que a permita "comprar um apartamento e encontrar um parceiro e finalmente iniciar uma família para balancear sua carreira" (PALAHKIUN, 2015, p. 19. Tradução nossa.) ${ }^{32}$, o que representa seu desejo de encontrar a tão estimada conexão humana. O maior medo de Macaca é não conseguir conquistar esse lugar ao sol, não ser amada por ninguém, como podemos ver no trecho "Quando o sol nasceu em Orlando, a Macaca se vestiu e se maquiou, preocupada que nunca seria amada por ninguém. Nunca teria um lar de verdade" (p. 21) 33 $^{33}$ e é essa preocupação que a motiva a defender o queijo, produto repudiado por todos os animais que não o provaram e no qual ela tem tanta fé, que a faz abrir mão de seu orgulho e se rebaixar, na esperança de que alguém provasse o queijo e compreendesse o que ela sentiu, pois "Se aquilo acontecesse, aquele bravo animal também amaria o queijo e a Macaca não estaria mais sozinha no mundo" (p. 25-6) ${ }^{34}$. A atitude socialmente aceitável que Macaca deveria ter tomado era se livrar das amostras de queijo, conforme recomendado por seus superiores, e seguir em frente, mas ela escolheu desafiar as normas sociais, transgredir o bom senso e submeter-se ao nojo indisfarçado dos outros pela chance mínima de que alguém a compreendesse. Trata-se de mais um romance contemporâneo de Palahniuk.

\footnotetext{
32 “[...]buy a condo and find a mate and finally begin a family to balance her career." (PALAHNIUK, 2015, p. 19).

33 "As the sun rose on Orlando, Monkey got dressed and put on her makeup, worried that no one would ever love her. She'd never have a real home." (PALAHNIUK, 2-15, p. 21).

34 "If that were to happen, that brave animal would also love the cheese and Monkey would no longer be alone in the world." (PALAHNIUK, 2015, p. 25-6).
} 


\subsubsection{Zombies}

Dando sequência, "Zombies" é o quarto conto da coletânea. Ele foi originalmente publicado na edição de novembro de 2013 da revista Playboy, e em 19 de agosto de 2014 foi disponibilizado gratuitamente no site da revista ${ }^{35}$. Nele, um garoto conta a história de como um outro garoto de sua escola, superdotado e com um futuro brilhante pela frente, decidiu abrir mão de tudo e fritar o próprio cérebro com o desfibrilador da enfermaria para não ter mais que se preocupar com nada. A partir daí vários outros estudantes decidem fazer o mesmo: o rei do baile, a capitã das líderes de torcida, os jovens mais promissores da cidade escolhem viver para sempre como portadores de necessidades especiais a ter de lidar com faculdade, carreira, família e imposições da sociedade como um todo.

Isso vira febre entre os jovens da região, os jornais tentam abafar, os pais e diretores se desesperam, e o tio do narrador decide manda-lo para outra cidade, a fim de impedir que ele copie o gesto de seus amigos. No aeroporto, o garoto toma a decisão de se desfibrilar também e, ao andar até o seu tio no portão de embarque para se despedir, já com os eletrodos colados nas têmporas e com o dedo sobre o botão vermelho, todos os presentes no aeroporto se unem em uma corrente para salvá-lo repetindo "se você se machucar, me machuca também". Vemos, mais uma vez, acontecer aqui exatamente o que Palahniuk disse fazer com seus textos: uma personagem que se sente sozinha e isolada encontra lugar em uma comunidade. Ainda que esse pertencimento seja momentâneo e a conexão se quebre assim que ele desistir de apertar o botão, ele percebe que seus medos, angústias e inseguranças não são só seus e permite-se um recomeço.

É interessante notar aqui que, apesar do final feliz e da situação retratada fugir tanto da realidade (a começar pelo fato de que desfibriladores só funcionam quando não há batimentos cardíacos), o conto põe em evidência a insatisfação do jovem perante o que é esperado dele hoje em dia. A sociedade (tanto a norte-americana quanto a brasileira), as instituições de poder, a mídia, a família, todos esperam que os jovens sejam bem sucedidos, que tenham uma carreira, um emprego que pague bem, que formem família, casem-se, tenham filhos, vão à igreja aos domingos, acompanhem as vidas das celebridades como se de fato fossem relevantes e se satisfaçam com uma vida média de comercial de margarina, com modelos pré-concebidos e impostos. Seria mesmo uma boa

\footnotetext{
${ }^{35}$ Disponível em: https://www.playboy.com/articles/zombie-chuck-palahniuk-fiction. Acesso em junho de 2016.
} 
vida de se levar? Se tivessem a opção de viver sem preocupações, cobranças, arrependimentos, de apenas aproveitar a vida e serem felizes, não a escolheriam também?

\subsubsection{Loser}

"Loser" é o quinto conto da coletânea. Aqui, o narrador é o calouro de uma universidade tradicional não especificada que está se candidatando para uma das fraternidades, a Zeta Delta. Para conseguir entrar, ele e vários outros calouros e veteranos Zeta Deltas vão até um estúdio participar de um programa de auditório em que têm de acertar o preço de produtos colocados no palco. O problema é que tomam LSD, sem saber como isso os afetará, e quando o narrador é chamado ao palco para participar do jogo, descreve uma experiência que, como o título já sugere, não termina nada bem.

A crítica que podemos perceber imediatamente ao ler o conto é quanto à alienação do jovem de hoje. O importante na vida dele é passar pela escola e pela faculdade para conseguir um bom emprego, sem necessariamente aprender muito. Criticam-se também as fraternidades nas universidades norte-americanas e como elas funcionam como um divisor de classes dentro da academia. Fazer parte de determinada fraternidade, além de conceder status, facilita no momento de encontrar o emprego perfeito em uma corporação perfeita que levará o indivíduo ao sucesso - e sucesso, no caso, é uma vida padronizada com emprego corporativo, bom salário, esposa, filhos e férias na Disneylândia. Acrescenta-se a isso o uso indiscriminado de drogas (muito presente nos textos de Palahniuk como válvula de escape de uma vida sem perspectivas), que a personagem faz sem saber que efeito o LSD terá, apenas porque é "tradição". E, enfim, o narrador, um jovem claramente alienado, por conta da droga começa a alucinar e perceber que nada disso está certo e que, apesar de não saber o que quer da vida, não pode ser aquilo.

A transgressão do conto se encontra na crítica alegórica à sociedade de consumo, de alienação e ao sistema educacional. É feita de forma exagerada, como podemos ver na seguinte passagem:

Na rodada seguinte, cê tem que adivinhar o preço de batatas, mas é, tipo, uma parada grande de batatas de verdade, vivas, de antes de virar comida, do jeito que elas vêm dos mineradores ou da galera lá que escava batatas na Irlanda ou Idaho ou algum outro lugar que começa com "I". Nem viraram chips de batata ou batatas fritas ainda.. $\left(2015\right.$, p. 43 . Tradução nossa) ${ }^{36}$.

\footnotetext{
36 "The next round, you need to guess the price of some potatoes, but like a whole big thing of real, alive potatoes, from before they become food, the way they come from the miners or whoever that dig potatoes in Ireland or Idaho or some other place starting with an "I." Not even made into potato chips or French fries". (2015, p. 43)
} 
Ao apresentar uma personagem que nunca viu uma batata crua, que está acostumada a receber tudo pronto para consumo, o autor põe em evidência - de forma exagerada, como de costume - a falta de consciência do jovem de classe média de hoje em dia, que nem ao menos se interessa em saber a procedência daquilo que come. Esse exagero se justifica pela tentativa de acordar o leitor com um choque de realidade, fazêlo perceber que há algo de errado com seu modo de vida, tentativa que fica ainda mais evidente pelo fato de a narrativa ser na segunda pessoa. Sabemos pelo contexto do conto que se trata de um jovem rapaz, mas ao longo de toda a sua história ele se dirige ao leitor e conta como "você fez isso" ou "você fez aquilo", como se estivesse guiando o leitor pela lembrança de uma experiência que ele, leitor, teve, de modo que ele se vê no lugar da personagem, sob o efeito de LSD, questionando as escolhas que fez na própria vida.

Na seguinte passagem, vemos o momento epifânico em que o narrador se dá conta de que algo não está certo:

\begin{abstract}
É tipo, se cê viver uma vida entediante o bastante, sabendo o preço de arroz instantâneo e salsicha de cachorro-quente, sua grande recompensa é ir passar uma semana num hotel em Londres? Cê ganha a oportunidade de viajar de avião pra Roma. Roma, tipo, na Itália. Cê enche a cabeça até o talo com baboseiras sem relevância e em troca disso ganha supermodelos gigantes te dando uma motoneve de presente? (2015, p. 46. Tradução nossa) ${ }^{37}$.
\end{abstract}

É comum que, ao fim das histórias de Palahniuk, suas personagens tenham essa percepção de que precisam mudar o rumo de suas vidas, de que, ainda que cheios de incertezas, aceitam o fato de não saberem o que querem porque sabem que não querem ser meros resultados de uma sociedade impositiva, não querem corresponder expectativas de um futuro planejado, padronizado. A crítica se torna ainda mais clara quando, nos últimos momentos da história, depois que o narrador já perdeu tudo, a vovó que ganhou tudo em seu lugar e está comemorando com sua família a aquisição de inúmeros bens de consumo fúteis, leva a mão ao peito, indicando seu ataque cardíaco. A história acaba aqui e não fica claro se ela chega a morrer, mas a mensagem foi passada: conquiste todos os bens materiais que sempre sonhou, conquiste uma casa enorme, um carro potente, tenha roupas de marca, áreas de lazer, viagens, tenha tudo que o dinheiro pode comprar (ou que um programa fruto da sociedade capitalista de consumo pode te dar), mas saiba que nada

\footnotetext{
37 "It's like, if you live a boring-enough life, knowing the price of Rice-A-Roni and hot dog wieners, your big reward is you get to live for a week in some hotel in London? You get to ride on some airplane to Rome. Rome, like, in Italy. You fill your head full of enough ordinary junk, and your payoff is giant supermodels giving you a snowmobile?" (2015, p. 46)
} 
disso te torna imortal, nada te salva na hora da morte ou te acompanha além-túmulo. Espera-se que esse tipo de senso crítico seja despertado em seus leitores.

Levando em conta tudo que foi apresentado até então, no capítulo seguinte pretendemos compreender de que forma se dá a tradução de textos desse gênero, o que a justifica e quais os maiores desafios encontrados ao lidar com essas narrativas, de forma a auxiliar a tradução dos contos que selecionamos e fundamentar nossa estratégia de tradução. Análises aprofundadas sobre linguagem, estilo e vozes narrativas dos contos, reservamos para o terceiro capítulo, onde abordaremos esses aspectos juntamente com comentários sobre sua tradução. 


\section{CAPÍTULO 2}

No momento da tradução de um texto transgressivo, muitos fatores estão em jogo. Devemos levar em conta que os textos são costumeiramente centrados em sociedades e culturas específicas, o que os torna ricos em expressões idiomáticas e dialetais (quando se trata da fala de uma comunidade muito específica, como é o caso do inglês escocês de Traisnpotting (1991), como vimos no Capítulo 1), referências culturais e políticohistóricas muito particulares e, acima de tudo, lidam com temas tabus - drogas, violência, sexualidade, práticas sexuais, incesto, pedofilia e crimes das mais diversas naturezas, como já foi dito.

Trata-se, portanto, de textos sensíveis. Mariú Lopes, em seu artigo A sensibilidade na tradução de textos sagrados (2009), tenta compreender e explicar o que caracterizaria um texto como sensível. Ela se apoia, principalmente, nas afirmações de Karl Simms, feitas em sua obra Translating sensitive texts: linguistic aspects (1997), refletindo que a manifestação sensível não advém do texto em si, mas das relações situacionais a que ele se submete e do contexto que potencializa sua sensibilidade. Um texto é sensível quando é percebido como tal (e ele pode ser compreendido de diversas formas, em diferentes contextos) e, sendo fruto de determinada circunstância, pode ser que tais circunstâncias provoquem reações no público leitor e, logo, o texto também provoque, por estar associado a elas (LOPES, 2009, p. 66).

Em sequência, a autora apresenta as quatro bases determinadas por Simms sobre as quais os textos costumam ser enxergados como sensíveis: “Tradicionalmente, as quatro bases sobre as quais um texto pode ser considerado sensível são aquelas que podem ser contraditórias ao Estado; à religião (eu ampliaria essa à "cultura"); ao pudor; ou aos cidadãos comuns" (SIMMS, 1997, apud LOPES, 2009, p. 67). Considerando isso, é possível concluir que o texto transgressivo realmente apresenta caráter sensível, por atacar essas quatro esferas, o que torna sua tradução sensível também, exigindo muito do tradutor.

É necessário que ele supere a autocensura e se desprenda do costume de seguir as normas da língua padrão e de medir suas palavras, para não limitar a tradução em uma tentativa de podar a narrativa oralizada e a linguagem chula, as imagens chocantes e temas polêmicos. É preciso também superar as tendências paternalistas de entregar tudo já processado para o leitor, supondo que este quer um texto de fácil compreensão, e deixar que ele se esforce para absorver os elementos culturais presentes no material. É um 
processo de desfamiliarização, de aceitar estranhar a si mesmo, confrontar sua própria língua e linguagem e seus valores; assim como o leitor do texto transgressivo, o tradutor precisa sair de sua zona de conforto.

François Laplantine e Alexis Nouss (2004), acreditam que a tradução deva ser um encontro de culturas, não a transferência de uma à outra em que o texto traduzido pretende substituir o original. Eles rejeitam a linha de pensamento que assombra boa parte dos Estudos de Tradução com noções de equivalência e fidelidade e recebe o estrangeiro retirando-lhe qualquer estranheza, qualquer marca do texto que o identifique como "outro" e cause desconforto no leitor. Os autores acreditam que essa teoria se descontrói sozinha, uma vez que um texto, não se tratando apenas de língua, mas também de letra, carrega em cada linha uma sociedade, uma cultura, uma visão de mundo, simbolismos, particularidades infinitas e "não existe reino platónico onde o sentido seja unívoco e que se mostra impossível anular o contexto, o quadro cultural e a rede de conotações do texto original” (LAPLANTINE, NOUSS, 2004, p. 40).

A tradução deveria, pois, ser vista como uma forma de, ao invés de distanciar línguas e culturas, evidenciar sua multiplicidade, variedade, diferenças e até mesmo como uma oportunidade de confrontá-las. Como colocam Laplantine e Nouss quanto à função da tradução,

\footnotetext{
O seu papel é, pois, o de lembrar aos leitores de uma determinada língua que é possível dizer o mundo de uma outra forma, com uma outra pronúncia, com outras cores; o de fazer ouvir a língua alheia na sua própria língua e deixar entrar nela uma estranheza que enriquecerá as possibilidades de expressão e a identidade do sujeito. O mesmo só existe quando reconhece o outro, tanto fora de si quanto no seu seio. (LAPLANTINE, NOUSS, 2004, p. 41-2).
}

Levando isso em conta, pretendemos desenvolver aqui um projeto de tradução que torne possível essa aproximação entre duas sociedades, entre dois povos e duas culturas. É claro que, no caso da tradução de textos da literatura norte-americana, tal tarefa, apesar de desafiadora, é facilitada pelo contato massificado que temos com essa cultura, sendo constantemente influenciados por ela ao importar produtos, ideias e modos de vida. Esse contato foi intensificado nos últimos anos pelo crescimento das mídias e redes sociais, que possibilitou o acesso globalizado e em tempo real a pessoas e ideias de qualquer lugar do mundo.

Em todo caso, nossa intenção enquanto tradutores de um gênero textual que aborda uma parcela marginalizada da sociedade e que busca romper, por meio da crítica satírica, a bolha do "American way of life", é evidenciar os elementos socioculturais postos a mostra no texto de partida para que o leitor brasileiro possa absorver essa 
sociedade de uma fonte diferente da convencional. Nosso comportamento, diante dessas marcas de linguagem e cultura, foi de tentar transmiti-las ao leitor, no que Paulo Henriques Britto chama de efeito de verossimilhança (2012), e fazer com que ele sinta o "sabor" da cultura de partida que Laplantine e Nouss defendem, a fim de que possa verdadeiramente encontrar e enxergar o estrangeiro por meio do texto, e até mesmo se identificar com esse outro a ponto de operar uma mudança em seu comportamento, despertando nele o senso crítico em relação à sociedade do outro e à sua própria.

\subsection{Tradução e violência}

Acreditamos que a tradução possui também um potencial transgressivo e que, por vezes, pode representar um ato de violência, ideia apoiada por autores como Kanavillil Rajagopalan e Lilia Baranski Feres. Rajagoplan, em seu artigo "Traição versus transgressão: reflexões acerca da tradução e pós-modernidade" (2000), diz acreditar que a atividade tradutória "via de regra, acarreta um certo grau de violência" (2000, p. 124). Assim como Laplantine e Nouss, o autor apresenta as duas vertentes de tradução: por um lado a de tradição logocêntrica, que pretende evitar "perdas, danos, e estragos ao conteúdo transportado" e que, ainda que reconheça a existência de atritos entre as partes da tradução, advoga "a eliminação, ou ao menos a diminuição considerável, de qualquer violência mediante atenção redobrada à letra e ao espírito do texto 'original' e compromisso solene com a fidelidade" (RAJAGOPALAN, 2000, p. 124); e, por outro, as teorias pós-modernas, mais recentes e heterodoxas, que, ao invés de relegar a tradução a uma posição secundária e tentar tornar o tradutor invisível, enxerga a tradução como "a única forma de acesso a qualquer texto, mesmo que redigido na língua materna do leitor" (RAJAGOPALAN, 2000, p. 125), e preserva a identidade do texto, o "sabor" estrangeiro da obra.

Para Rajagopalan, toda tradução - todo ato de comunicação, na verdade - passa por um ato de violência ao se "apropriar do texto original" (RAJAGOPALAN, 2000, p. 124). Sendo assim, as duas formas de tradução (bem como as estratégias intermediárias) são, de alguma forma, violentas. A estratégia mais domesticadora (Rajagopalan faz uso dos conceitos de domesticação e estrangeirização de Lawrence Venuti (1995)) é violenta com o texto de partida, apropria-se dele de forma escancarada e o modifica a seu bel prazer, ao passo que a estratégia estrangeirizadora se apropria do texto fonte de forma mais sutil, em uma tradução transgressora, violenta o texto de chegada e seu leitor ao 
preservar o estrangeirismo que lhe será estranho quando da leitura (RAJAGOPALAN, 2000, p. 127) e é nesse momento que ocorre a transgressão.

Lilia Baranski Feres contribuiu ainda mais com a perspectiva da tradução como transgressão em sua apresentação no $6^{\circ}$ Seminário Brasileiro de Estudos Culturais e Educação (2015), "Tradução: entre a transgressão e narcisismo", ao propor que uma tradução seria transgressora quando "desloca o leitor até a obra estrangeira, [...] ultrapassa fronteiras, submete-o ao confronto com uma pluralidade de identidades, ao mesmo tempo em que expõe a cultura nacional (do leitor) a influências externas" (FERES, 2015). Se enxergarmos a tradução por esse viés, ela se torna o agente que coloca o leitor do texto frente a frente com a cultura do outro para que, assim, possa perceber a sua própria. Considerando essa definição de Feres, é possível considerar a tradução que propomos como transgressiva, pois há, a todo momento, a preocupação de transportar o leitor para a obra estrangeira e colocá-lo frente a frente como outro. Tira-lo de sua zona de conforto configuraria um ato de violência, mas se essa violência faz com que ele passe a refletir e questionar aquilo que sempre aceitou como natural, estimulando-o a operar mudanças em sua sociedade, ela causa mais bem do que mal.

\subsection{A ficção transgressiva no polissistema literário}

A teoria dos polissistemas nasceu nos trabalhos do pesquisador israelense Itamar Even-Zohar entre os anos de 1969 e 1970, tendo sido reelaborada e desenvolvida em seus estudos posteriores e, mais tarde, se tornado objeto de pesquisa e discussão de diversos outros estudiosos ao redor do mundo. Na introdução da edição do Poetics today com a qual colaborou em 1990 (p. 1), Even-Zohar explica que o que o motivou a criar a teoria foi a necessidade de solucionar problemas específicos de suas pesquisas relacionados à teoria da tradução e à complexa estrutura histórica da literatura hebraica, e que teve como base as noções de sistema do Formalismo Russo dos anos 1920.

Essa teoria compreende uma cultura como um sistema composto internamente por diversos sistemas menores correlacionados e, por sua vez, parte de um sistema maior que abrange os sistemas de outras culturas. Esse conjunto de sistemas é chamado de polissistema e possui caráter dinâmico e hierárquico, com os (polis)sistemas que dele fazem parte constantemente redefinindo suas fronteiras e posições de poder, alternando entre lugares centrais e periféricos. Segundo Even-Zohar: 
intersecções e, logo, a maior complexidade de estruturação envolvida. Além disso, ele reforça que para que um sistema funcione, a uniformidade não deve ser postulada. Uma vez que a natureza histórica de um sistema seja reconhecida (um grande mérito do ponto de vista da construção de modelos mais próximos à "realidade"), pode-se prevenir a transformação de objetos históricos em uma série de ocorrências a-históricas não relacionadas. (EVEN-ZOHAR, 1990, p. 12. Tradução nossa) ${ }^{38}$.

Em outras palavras, pensar no sistema de determinada cultura como sendo um polissitema facilita a compreensão de que os elementos que o constituem possuem carga histórica e não funcionam de maneira isolada e estática; pelo contrário, influenciam e sofrem a influência de vários outros elementos ao seu redor e sua análise deve levar isso em consideração. Por serem dinâmicos, há sempre entre os sistemas e entre os elementos de cada sistema uma tensão causada pela tentativa ininterrupta dos elementos centrais de manterem sua posição e dos elementos periféricos de alcançarem tal centralidade.

O polissistema em que Even-Zohar concentrou sua pesquisa foi o literário, que se forma em função de outros polissistemas, como o social, cultural e histórico, e funciona a partir de um agregado de sistemas menores que representam textos, autores, editoras, livrarias, público leitor, público consumidor etc. Os jogos de poder dos componentes desse polissistema se referem, por exemplo, à luta pela preferência dos leitores, por recordes de venda, por posições de destaque em listas reconhecidas de best-sellers, por prêmios importantes e por sua colocação (e manutenção) em um lugar proeminente no cânone literário. O próprio cânone é um sistema a parte (porém integrado) em que obras canonizadas se esforçam para se manterem canônicas e obras periféricas se esforçam para atingir o status de cânone, disputa essa que envolve muitos dos polissistemas já mencionados, considerando que a mudança de determinado elemento do centro para a periferia e vice-versa tem efeito imediato na posição de elementos de polissistemas paralelos.

Dos estudos realizados pelo pesquisador israelense, o que mais nos desperta interesse é aquele referente à posição da literatura traduzida no polissistema literário. Sobre isso, Even-Zohar fez várias indagações, que resultaram em uma conferência proferida no Colóquio Internacional "Literature and translation: new perspectives in

\footnotetext{
38 "the term "polysystem" is more than just a terminological convention. Its purpose is to make explicit the conception of a system as dynamic and heterogeneous in opposition to the synchronistic approach. It thus emphasizes the multiplicity of intersections and hence the greater complexity of structuredness involved. Also, it stresses that in order for a system to function, uniformity need not be postulated. Once the historical nature of a system is recognized (a great merit from the point of view of constructing models closer to "the real world"), the transformation of historical objects into a series of uncorrelated a-historical occurrences is prevented." (EVEN-ZOHAR, 1990, p. 12).
} 
literary studies", na Universidad Católica de Lovaina, de 27 a 30 de abril de 1976, e, posteriormente, na publicação, como parte da obra de mesmo nome do colóquio, editada por James S. Holmes, Jose Lambert e Raymond van den Broek (1978, p. 117-127), de um texto intitulado The position of translated literature within the literary polysystem. $\mathrm{O}$ mesmo texto foi, mais tarde, publicado na edição da Poetics today (1990) e é com essa versão que trabalharemos aqui.

Logo no início do texto, o autor admite um cenário que é bem conhecido pelos estudiosos da tradução, em particular do século XX:

\begin{abstract}
Apesar do amplo reconhecimento, entre os historiadores da cultura, do papel de destaque que a tradução desempenha na cristalização das culturas nacionais, o número de pesquisas conduzidas nessa área ainda é relativamente pequeno.

Via de regra, as histórias das literaturas mencionam as traduções quando não há como de evitá-las, [...] mas raramente elas são incorporadas ao escopo histórico de uma forma coerente. Por consequência, dificilmente se tem qualquer ideia da função exercida pela literatura traduzida na literatura como um todo ou de sua posição dentro dessa literatura. Além do mais, não há reconhecimento da possibilidade de a literatura traduzida existir como um sistema literário específico. O conceito que prevalece é mais o de "tradução" ou de "obras traduzidas" tratadas individualmente. (EVEN-ZOHAR, 1990, p. 45. Tradução nossa). ${ }^{39}$
\end{abstract}

Even-Zohar foi um dos primeiros teóricos a questionar essa posição da literatura traduzida e a sugerir que ela pudesse, sim, ocupar um lugar central em alguns polissistemas literários, ao contrário da posição marginalizada sempre atribuída a ela. Isso porque o sistema da literatura traduzida não funciona de forma isolada da literatura nacional; a seleção dos textos fonte a serem traduzidos tem relação direta com o que acontece na literatura alvo em dado momento e a maneira como esses textos serão traduzidos costuma seguir normas e comportamentos do repertório da literatura nacional, o que torna imperativo que se reconheça e estude a literatura traduzida como um sistema integral e ativo dentro do polissistema literário. Tendo isso em mente, resta saber qual a posição dessa literatura traduzida dentro do polissistema, se central ou periférica, e como ela influencia e é influenciada pelo repertório global, comportando-se de maneira inovadora (primária) ou conservadora (secundária) (1990, p. 46).

\footnotetext{
39 "In spite of the broad recognition among historians of culture of the major role translation has played in the crystallization of national cultures, relatively little research has been carried out so far in this area.

As a rule, histories of literatures mention translations when there is no way to avoid them, [...] but they are seldom incorporated into the historical account in any coherent way. As a consequence, one hardly gets any idea whatsoever of the function of translated literature for a literature as a whole or of its position within that literature. Moreover, there is no awareness of the possible existence of translated literature as a particular literary system. The prevailing concept is rather that of "translation" or just "translated works" treated on an individual basis." (EVEN-ZOHAR, 1990, p. 45).
} 
Observando o posicionamento, movimentação e relações de poder entre centro e periferia, o autor argumenta $(1990$, p. 47) que, para que uma literatura traduzida ocupe lugar central na história literária de um país, são necessários os seguintes contextos:

a) a literatura de tal cultura é muito "jovem" e o polissistema ainda não se solidificou;

b) o polissistema da literatura de chegada, quando comparado com outras literaturas, é considerado "periférico" e/ou "fraco"; ou

c), quando há reviravoltas, crises ou lacunas literárias na literatura deste país.

Nesses casos, a literatura traduzida pode servir para que a literatura de chegada ponha em prática uma linguagem literária recém-encontrada ou renovada que por quaisquer motivos não possa empregar em um texto nacional ou, como é mais comum, pode assumir um caráter vanguardista, contribuindo para o desenvolvimento e aperfeiçoamento do polissistema de chegada ao introduzir novos modelos de linguagem, técnica e estética. Ela teria aqui uma função primária dentro da literatura alvo e pode, inclusive, ser uma oportunidade de criação literária.

Por outro lado, em polissistemas de literatura nacional mais "forte", em que a literatura traduzida ocupa uma posição periférica e secundária, "ela não exerce influência alguma nos processos maiores e é moldada de acordo com normas já convencionalmente estabelecidas por um tipo já dominante na literatura alvo" (1990, p. 48. Tradução nossa $)^{40}$. Isso faz com que as traduções sejam obras conservadoras, que seguem padrões e normas cultas, caso exista na língua, sem espaço para o desenvolvimento de novos modelos.

Even-Zohar ressalta que o fato de a literatura traduzida ser central ou periférica não implica que ela seja totalmente uma coisa ou outra; o polissistema da tradução também é estratificado e enquanto alguns textos (não apenas textos, como também tradutores, editoras etc) acendem ao centro, outros permanecem às margens, podendo haver mudanças drásticas nesse cenário, ao passo que esses elementos também estão sujeitos aos jogos de poder do sistema dinâmico. No entanto, o autor acredita que, tanto seus estudos quanto o de vários outros estudiosos, indicam que a posição normalmente assumida pela literatura traduzida seja a periférica (1990, p. 49).

É importante identificar o posicionamento da literatura traduzida, pois é ele que vai determinar a forma com que os tradutores lidam com o texto. Quando localizada mais ao centro, o tradutor tem a liberdade, bem como o papel, de criar modelos primários e

\footnotetext{
40،it has no influence on major processes and is modelled according to norms already conventionally established by an already dominant type in the target literature." (EVEN-ZOHAR, 1990, p. 48).
} 
inovadores e violar convenções da literatura alvo, tornando-se autor de uma "semitradução" que se aproxima mais do texto original e, caso aceita pelo sistema de chegada, pode enriquecer o repertório nacional (1990, p. 50-51). Em contrapartida, quando localizada às margens do polissistema, cabe ao tradutor encontrar os melhores modelos secundários já existentes no repertório para traduzir aquele texto estrangeiro e os resultados costumam ser inadequados ou apresentar grande discrepância entre a “equivalência alcançada e a adequação postulada" (1990, p. 51).

A partir dessa constatação de Even-Zohar, de que a atividade tradutória estava sujeita às relações em jogo dentro de determinado sistema cultural, ampliou-se a noção de tradução e outros pesquisadores da área passaram a trabalhar com abordagens nãoprescritivas de estudo. A partir daí, as discussões deixaram de se limitar às noções de equivalência existentes entre original e tradução e abandonaram um pouco o foco no texto e local de partida para voltar seus olhares ao polo receptor. Um desses estudiosos, e talvez o que mais desenvolveu trabalhos descritivos sobre a tradução, foi Gideon Toury.

Toury foi colega de Even-Zohar em Tel Aviv e foi muito influenciado pelo trabalho deste. A partir de sua pesquisa sobre como condições socioculturais afetavam a tradução de obras estrangeiras para o hebraico, que o motivou a elaborar uma teoria de tradução mais abrangente, publicou, em 1980, o livro In search of a theory of translation, no qual delineou suas primeiras ideias sobre os Descriptive Translation Studies, ou DTS (em português, Estudos Descritivos da Tradução).

Marcia Martin, em sua tese de doutorado (1999), explica que os DTS surgiram, então, como uma alternativa para os Estudos da Tradução, que até então se limitavam a uma abordagem normativa, que discursava cansativamente sobre o que a tradução é, o que deveria ser, e sobre a relação entre o texto traduzido e seu original, focando-se especificamente na língua fonte como referência. Ao longo dos anos seguintes, Toury desenvolveu mais a fundo seus estudos descritivos e, em 1995, lançou Descriptive translation studies and beyond, no qual chama atenção para a necessidade de se haver uma abordagem descritiva dos Estudos da Tradução e propõe suas normas da tradução.

O centro de estudo dos DTS é o produto da tradução, a definição do espaço que esta ocupa no sistema literário de chegada, seu desenvolvimento histórico e função no mercado editorial, bem como o que motivou a tradução de tal texto. Para Toury (1995) é a cultura alvo que determina a necessidade de uma tradução e a reprodução de um padrão estético por determinado tradutor, assim como Even-Zohar (1990) já havia sugerido. 
As normas de tradução desenvolvidas por Toury não possuem caráter prescritivo, pois são apenas postulados relativos às ideias e valores comuns sobre a tradução, compartilhados por uma maioria de tradutores, em determinado contexto e período. Toury as divide em três categorias:

- Normas preliminares - Abrange questões como a seleção dos textos e autores a se traduzir e a motivação, a estratégia tradutória global e a entrada de tais textos no sistema-alvo; também se será uma tradução direta e qual a política tradutória. Os editores normalmente é que são responsáveis por essas escolhas.

- Normas iniciais - Refere-se às decisões básicas tomadas pelo tradutor quanto a uma tradução adequada (utilização de normas e relações textuais do sistema de partida) ou aceitável (utilização de normas e relações textuais do sistema de chegada). É importante dizer que as opções não são excludentes, e o tradutor deve encontrar um equilíbrio entre elas com o qual trabalhar.

- Normas operacionais - Subdividindo-se em duas categorias, envolve as decisões tomadas durante a tradução do texto a respeito de:

a) Matriciais - Qualquer acréscimo, omissão e alteração feitas na matriz do texto.

b) Textuais - Preferências linguísticas e estilísticas.

O teórico israelense (1995) afirma que essas normas servem para determinar o comportamento de uma tradução no contexto de chegada, e que foram criadas para abranger todo e qualquer tipo de texto traduzido, sendo, assim, flexíveis. Seriam elas, também, que possibilitam os estudos da tradução social e historicamente.

O que foi visto até aqui sobre a Teoria do Polissistema e os DTS, permite-nos tentar compreender o lugar ocupado pela ficção transgressiva no polissistema literário brasileiro e, para tal, é importante saber, também, que posição ele detém no polissistema norte-americano. Com base no panorama histórico que traçamos no capítulo anterior, fica claro que os acontecimentos do pós-guerra impactaram e influenciaram em muito a produção cultural do restante do século, motivando o surgimento de muitos textos que desejavam expressar seu descontentamento com a sociedade de consumo, o capitalismo exacerbado, as guerras (em especial a Fria, com potencial atômico, e a do Vietnã, que ocasionou tantas mortes) e toda uma situação de conformismo que tomava conta do cidadão estadunidense. A literatura que resultou disso, como pudemos perceber, apresenta fortes traços transgressivos, dando, posteriormente, origens aos autores que fazem parte da ficção transgressiva iniciada entre o fim dos anos 1980 e início dos anos 
1990. Mais importante que isso, porém, é o fato de que essa literatura sobre indivíduos marginalizados, alcançou o centro do polissistema literário norte-americano, tornando-se canônica.

Podemos confirmar essa afirmação ao analisar guias de estudo da literatura através dos anos. No livro The Twentieth-century American fiction handbook (2011), Christopher MacGowan faz um apanhado histórico de todo o século XX, explicando que eventos e contextos levaram ao surgimento das obras e autores que marcaram as décadas passadas. Em seguida, ele analisa os escritores e os textos mais importantes do século e é interessante notar que, dentre os 31 autores selecionados, cinco podem ser considerados transgressivos, sendo eles Vladmir Nabokov, William S. Burroughs, Norman Mailer, Don DeLillo e Thomas Pynchon. Isso não parece muito, mas quando vemos a lista dos textos mais importantes, é surpreendente: dentre os 31, nove são obras transgressivas, ou seja, quase um terço do melhor que se produziu na literatura norte-americana do século XX. Estão entre elas The catcher in the rye (1951), de J. D. Salinger, Wise Blood (1952), de Flannery O'Connor, Invisible man (1952), de Ralph Ellison, On the road (1957), de Jack Kerouac, Lolita (1958), de Vladmir Nabokov, e Naked lunch (1962), de William S. Burroughs.

Não passa despercebido por nós o fato de que, ao atingir o centro e tornar-se cânone, a obra é absorvida pelo sistema e corre o risco de perder seu potencial transgressivo. No entanto, sua transgressão pode se manter viva nos novos autores e obras que ela influencia e que tentarão transgredir os limites sociais, culturais, políticos, religiosos etc. de outras maneiras, mantendo sempre atualizada a crítica social e renovando o potencial de operar mudanças sociais que tem a literatura como um todo e a ficção transgressiva em particular.

Considerando o polissistema literário ocidental (e talvez até mesmo o mundial), não é exagero dizer que o polissistema dos EUA ocupa posição central e fortemente estabelecida, uma vez que se trata da nação mais influente do mundo, em termos tanto econômicos quanto políticos quanto culturais. O Brasil, por sua vez, encontra-se em posição periférica, de um modo geral, estando sujeito à influência direta dos Estados Unidos em todos os aspectos. Dito isso, é possível assumir que essa literatura que surgiu do lado de lá a partir dos anos 1950 e se tornou canônica, teve efeito sobre a literatura do lado de cá, principalmente considerando a evolução nos meios de comunicação que facilitou o acesso a ideias em nível global. 
Karl Schollhammer, em sua obra Ficção brasileira contemporânea (2009), traça o histórico literário do país desde a década de 1970, até chegar na chamada "Geração 00", para tentar compreender como se constrói a literatura brasileira contemporânea, ao que ele diz que

\begin{abstract}
Uma das soluções mais frequentes é eleger uma década como definidora de cada geração, o que já criou definições bastante reconhecidas que fazem de 1970 a década de contistas urbanos, de 1980 a década da literatura pósmoderna no Brasil e de 1990 a geração de "transgressores", num tempo determinado pela escrita de computador e pela temporalidade imediata da Internet. A "Geração 00", por sua vez, ainda não ganhou um perfil claro, e nenhum grupo se identificou para escrever o manifesto e levantar sua bandeira da geração. (SCHOLLHAMMER, 2009, p. 17).
\end{abstract}

Ou seja, nem mesmo o Brasil escapou do boom transgressivo dos anos 1990. Apesar de produzir textos das mais diversas naturezas, uma grande parte dos autores reconhecidos pela crítica literária brasileira escrevia narrativas curtas e fragmentadas, com temas violentos e personagens em crise de identidade nacional, social e sexual. Surgem e/ou ganham notoriedade, a partir de meados dos anos 1980, escritores como João Gilberto Noll, Silviano Santiago, Chico Buarque de Hollanda, João Trevisan e Bernardo Carvalho, cujas obras acompanham personagens dessubjetivados ${ }^{41}$, e que prolongam sua prosa anos 1990 adentro.

Sobre a “Geração 90", Schollhammer comenta que foi, inicialmente, um golpe de marketing muito bem arquitetado. O romancista Nelson Oliveira organizou e lançou em 2001 uma coletânea de contos chamado Geração 90 - Manuscritos de computador, e, em 2003, Geração 90 - Os transgressores, reunindo, em ambas, autores que, a princípio, nada tinham a ver um com o outro (SCHOLLHAMMER, 2009, p 35). Aparentemente o rótulo de "transgressor" era uma coisa positiva, que conferiria nos anos 2000 algum tipo de status aos autores contidos nas antologias, que publicaram e se tornaram conhecidos na década de 1990. Ao tentar encontrar entre esses autores características em comum, Schollhammer afirma que a escrita da década de 1990, talvez influenciada pela nova tecnologia, tinha preferência pela prosa curta, formas de escrita instantâneas, flashes e stills fotográficos, mudanças de foco, cortes, e uso de outras técnicas do cinema. Além disso, os anos 1990 viram florescer o conto brasileiro, com escritores que o autor chama

\footnotetext{
${ }^{41}$ Schollhammer (2009) não deixa claro o que especificamente caracteriza o sujeito dessubjetivado, porém é possível entender, a partir de suas afirmações sobre as personagens dos autores supracitados, que tratamse de indivíduos sem rumo, que perderam sua identidade individual em meio a uma crise de identidade do homem moderno. De acordo com o pesquisador, "A perda de determinação e de rumo dos personagens é uma característica que a prosa da década de 1990 iria prolongar, em narrativas que oferecem o indivíduo como um tipo de fantoche, envolvidos em situações que flertam com o inumano [...]" (SCHOLLHAMMER, 2009, p. 33) e esse indivíduo é o sujeito dessubjetivado.
} 
de "clássicos contemporâneos": Dalton Trevisan, Lygia Fagundes Telles, Rubem Fonseca, Sérgio Sant'Anna, Murilo Rubião, entre outros (SCHOLLHAMMER, 2009, p. 36).

O autor segue apresentando obras dessa década que apresentam trações transgressivos: O matador (1995), de Patrícia Melo, e Cidade de Deus (1997), de Paulo Lins, ambas intimamente ligadas a uma realidade violenta da cidade grande e à maneira flagrante de expô-la; a coletânea de contos Fátima fez os pés para mostrar na choperia (1998), de Marcelo Mirisola, rica em humor, sarcasmo e agilidade narrativa; e, por fim, André Sant'Anna com suas obras Amor (1998) e Sexo (1999).

Pelo tipo de narrativa e temáticas desses autores, fica difícil não traçar um paralelo com o que estava sendo produzido quase ao mesmo tempo nos EUA, principalmente sabendo que foram traduzidas aqui obras como Naked lunch (1962), de William Burroughs, lançada como Almoço nu em 1984, pela Ediouro, e American psycho (1991), de Bret Easton Ellis, lançada como Psicopata americano em 1992, pela Rocco.

Estava estabelecido um público leitor para esse gênero e como, a partir dos anos 2000, os autores brasileiros se enveredaram por outros caminhos, como mostra Schollhammer na seção de seu livro dedicada à essa geração (2009, pgs. 147-161), abriuse espaço no mercado literário para que se importassem as obras transgressivas que a literatura nacional não mais produzia. Isso, atrelado ao sucesso internacional de adaptações cinematográficas como Traisnpotting (1996), de Danny Boyle, Clube da luta (1999), de David Fincher, e Psicopata americano (2000), de Mary Harron, auxiliaram para que fossem traduzidas, cada vez mais, obras de escritores transgressivos de língua inglesa.

Como vimos no capítulo anterior, ainda no ano 2000 foi lançado o Clube da luta em português; em 2003, sai Sobrevivente; em 2004, Cantiga de ninar, mesmo ano em que finalmente é lançada a tradução de Trainspotting, de Irvine Welsh, pela Rocco, com tradução de Daniel Galera e Daniel Pellizzari, e a LP\&M lança sua primeira edição de bolso de Pé na estrada, de Jack Kerouac, com nova tradução, introdução e posfácio de Daniel Bueno; em 2005, são lançados No sufoco, de Chuck Palahniuk, e uma retradução de Daniel Pellizzari de Almoço $n u$, de Burroughs, pela Ediouro, e assim acontece sucessivamente todos os anos, com inúmeras obras.

Em 2012, a editora Leya adquiriu os direitos de publicação de Chuck Palahniuk e, desde então, tem publicado a tradução de pelo menos uma obra sua por ano. Por algum motivo, que não podemos embasar com fontes, a popularidade do autor parece aumentar 
a cada dia, apesar de quase toda referência inicial que se faz a ele ser do filme Fight club, que está para completar dezoito anos desde seu lançamento. Talvez seja arriscado supor tal coisa, mas o status de filme cult, além do grande feito cinematográfico que ele representa, torna-o muito atraente para as novas gerações de cinéfilos e leitores, que muito possivelmente motivados pelo afeto pelo filme, dispõe-se a consumir a obra que o inspirou e, uma vez conquistados, continuam consumindo as obras de Palahniuk e de autores similares que chegam aqui por meio da tradução, sustentando, assim, esse nicho do polissistema literário.

\subsection{Reflexões sobre os gêneros literários dos textos traduzidos}

A fim de compreender melhor os textos para desenvolver uma estratégia de tradução, acreditamos ser válido estudar um pouco o gênero em que se encaixam: conto, no caso dos quatro, e fábula, no caso de "How Monkey got married, bought a house and found happiness in Orlando". O debate em torno dos gêneros literários é um dos mais antigos e polêmicos dos estudos da literatura. Um problema que ele levanta, por exemplo, é a definição das características próprias de cada gênero, se elas deveriam ser rígidas e pré-estabelecidas ou se deveriam ser flexíveis e se adaptar ao tempo e cultura em que o texto se origina. Discute-se, também, se tais aspectos teriam de ser exclusivos de cada gênero e como se classificariam textos de gêneros diferentes ostentando as mesmas qualidades. São inúmeras as questões propostas pelos teóricos e críticos ao longo dos anos e a visão desses estudiosos evoluiu a ponto de, a partir do século XX, compreender o gênero como um conceito de amplo significado e subtancialidade que enriquece o estudo e aceitação da obra como um todo.

Maria Lúcia Aragão, em seu Manual de Teoria Literária (1985, p. 65), ressalta que "Toda obra artística é autônoma em sua validade estética, mas não é independente da cultura de sua época e das influências da cultura de épocas anteriores", o que serve para mostrar que um gênero não pode funcionar como um sistema independente e imutável. Aragão, então, propõe uma classificação de gêneros literários que os divide em ensaístico, dramático, lírico e narrativo. No caso do gênero narrativo, foco do projeto, encontramos as subcategorias epopeia, romance, novela, conto e fábula, sendo que alguns teóricos também entendem a crônica como parte desse grupo.

No entanto, os princípios de caracterização destes gêneros são, independente das classificações sugeridas, muito subjetivos e genéricos, e se considerarmos, por exemplo, os perfis das personagens, temas e ritmo da narrativa não é possível separar um gênero 
do outro. A forma mais comum, portanto, de fazer essa distinção, tende a ser em termos de extensão textual, pois sabemos que um conto será mais curto que uma novela e que uma novela será mais curta que um romance — por mais sutil e imprecisa que seja a linha que os separa. Faremos, a seguir, breves reflexões sobre os gêneros narrativos que nos interessam como objeto de estudo.

\subsubsection{O conto}

Por se tratar de uma forma narrativa em prosa, geralmente de pequena extensão, os teóricos costumam definir o conto de forma limitada e empobrecedora. É o que faz Aragão (1985, p. 84) ao descrevê-lo como um gênero que "trata de uma determinada situação e não de várias, e acompanha o seu desenrolar sem pausas, nem digressões, pois o seu objetivo é levar o leitor ao desfecho, que coincide com o clímax da história, com o máximo de tensão e o mínimo de descrições". Um leitor assíduo de contos, porém, sabe que não é bem assim.

É possível que o contista, consciente do espaço reduzido de sua narrativa, omita ou deixe implícitas informações que seriam de outra sorte descritas, com o objetivo de enfatizar aquilo que é mais relevante para a trama e que causa mais impacto. De fato, a necessidade de causar impacto no leitor parece ser uma constante entre os autores do gênero. Em sua Filosofia da Composição (1987), Edgar Allan Poe afirma exatamente isso:

\footnotetext{
Se alguma obra literária é longa demais para ser lida de uma assentada, devemos resignar-nos a dispensar o efeito imensamente importante que se deriva da unidade de impressão, pois, se se requerem duas assentadas, os negócios do mundo interferem e tudo o que se pareça com totalidade é imediatamente destruído. [...] Pois é claro que a brevidade deve estar na razão direta da intensidade do efeito pretendido, e isto com uma condição, a de que certo grau de duração é exigido, absolutamente para a produção de qualquer efeito. (POE, 1987, p. 111-112).
}

Este argumento é reforçado por Julio Cortázar, que, em seu discurso Alguns aspectos do conto (1993), vale-se de sua experiência pessoal como contista para dizer que um conto deve ganhar o leitor desde o começo, ser impactante para forçar nele um sentimento e uma reflexão que irão além do fim da leitura. Segundo ele, um contista nunca desperdiça tempo e espaço e se surpreenderia se alguém pudesse encontrar, mesmo na primeira página de um conto "elementos gratuitos, meramente decorativos" (1993, p. 152). Cortázar sugere, ainda que o conto deve ser um recorte da vida cotidiana, de um acontecimento aparentemente sem importância que se tornará transformador e edificante 
nas mãos do bom contista (1993, p. 153). Devemos levar em conta, porém, que ao fazer essa afirmação, Cortázar tem em mente a noção moderna de conto desenvolvida por James Joyce em Portrait of the Artist as a Young Man (1916), e que o afasta da noção tradicional do conto.

Enquanto o conto tradicional se ocupa com recortes lineares da vida cotidiana e faz uma reflexão pouco aprofundada a seu respeito, o conto moderno apresenta flashes do dia-a-dia da personagem, mas se foca em momentos reveladores, epifanias que dão sentido à narrativa, mesmo que ela não vá a lugar algum. É o que acontece, por exemplo, em Dubliners (1914), de James Joyce, e Primeiras Estórias (1962), de Guimarães Rosa. Ao mesmo tempo, também não podemos generalizar e dizer que todos os contos trabalham com fragmentos do dia a dia, pois isso seria prender o gênero em uma caixinha de regras que já concluímos não poder existir.

Ainda em relação à extensão espacial do conto, Norman Friedman, em seu artigo O que faz um conto ser curto? (2004), estuda o caráter desse gênero em busca de uma explicação para a sua brevidade e mostra que é possível haver tanto estabilidade quanto mobilidade dentro de um texto pequeno:

\footnotetext{
Espero agora que já esteja claro que um conto pode ser estático ou dinâmico, apesar de, como vimos, uma ação estática normalmente requerer menos partes do que uma que é dinâmica e que irá, portanto, normalmente ocupar menos espaço na narrativa. Isso quer dizer que uma história estática simplesmente apresenta seu protagonista em uma ou outra situação e inclui apenas o suficiente para revelar ao leitor a causa ou causas das quais essa situação é consequência, enquanto uma história dinâmica conduz seu protagonista através de uma sucessão de duas ou mais situações e, assim, deve incluir muitas etapas causais das quais essas situações são consequência. Logo, uma história estática normalmente é mais curta do que uma dinâmica. (FRIEDMAN, 2004, p. 224).
}

Considerando os textos escolhidos para a tradução, vemos logo que "Loser" enquadra-se na noção de narrativa estática proposta, já que foca em apenas uma ação temporariamente linear e progressiva, que caminha de forma uniforme em direção ao clímax e momento epifânico da personagem. Já os outros três, apresentam as características de uma narrativa dinâmica e até mesmo podem se encaixar no esquema criado por Friedman para ilustrar as etapas de um conto dinâmico (2004, p. 227), como mostraremos na tabela a seguir com "How Monkey got married, bought a house and found happiness in Orlando", que apesar de fábula contemporânea também se comporta como conto: 


\begin{tabular}{|l|l|}
\hline \multicolumn{1}{|c|}{ Etapas de Friedman } & $\begin{array}{l}\text { Etapas de How Monkey got married, } \\
\text { bought a house and found happiness in } \\
\text { Orlando }\end{array}$ \\
\hline $\begin{array}{l}\text { 1) motivo introdutório para apresentá-lo } \\
\text { em sua situação original; }\end{array}$ & $\begin{array}{l}\text { 1) a personagem é apresentada como } \\
\text { funcionária modelo das Indústrias } \\
\text { Llewellyn; }\end{array}$ \\
\hline $\begin{array}{l}\text { 2) uma reviravolta para representar as } \\
\text { consequências dessa situação; }\end{array}$ & $\begin{array}{l}\text { 2) sua arrogância e orgulho fazem-na } \\
\text { pedir um desafio; }\end{array}$ \\
\hline $\begin{array}{l}\text { 3) um motivo incitante que irá servir para } \\
\text { movê-lo em direção a uma situação } \\
\text { oposta; }\end{array}$ & $\begin{array}{l}\text { 3) pela primeira vez em sua vida, ela se vê } \\
\text { fracassar ao não conseguir vender o } \\
\text { queijo; }\end{array}$ \\
\hline $\begin{array}{l}\text { 4) uma ação progressiva para representá- } \\
\text { lo num processo de mudança; }\end{array}$ & $\begin{array}{l}\text { 4) ao ser desafiada, ela come o queijo e } \\
\text { encontra algo para amar além de si } \\
\text { mesma; }\end{array}$ \\
\hline 5) um clímax no qual o processo estará \\
completo.
\end{tabular}

Com respeito ao processo de tradução do gênero em questão, não foi encontrada nenhuma literatura sugerindo estratégias específicas ou discutindo quaisquer dificuldades recorrentes, portanto, as conclusões a que chegamos são baseadas somente na prática da tradução dos contos selecionados para a pesquisa. Decerto, não se tratam de conclusões definitivas, uma vez que o material de análise é limitado, mas é possível afirmar que, por se tratar de um texto curto, com menos espaço e tempo para causar impacto e desenrolar sua narrativa, tudo nele acontece com mais intensidade, e da mesma forma que o autor do conto costura seu texto minuciosamente, pensando cada detalhe, foi preciso fazer o mesmo com a tradução, para que se atinja o efeito causado pela unidade de impressão, conforme sugerido por Poe (1987).

\subsubsection{A fábula}

A respeito do gênero fábula, sabe-se que é constituído de histórias curtas, ágeis e simbólicas, que abordam atitudes e vícios humanos e podem ser narrados em prosa, verso ou mesmo oralmente. Trata-se de um gênero que data mais de mais de dois mil anos, nascido de um impulso natural de contar histórias e mantido vivo pela tradição popular oral. Seu principal representante é Esopo, escravo grego que viveu entre os séculos VII e 
VI a.C. e que, vale ressaltar, não chegou a escrever suas fábulas, apenas conta-las. Outro grande nome do gênero é Jean de La Fontaine, que, no século XVII, recriou as fábulas de Esopo e de outros fabulistas, como Babrios e Fedro, além de escrever suas próprias.

As fábulas, como qualquer outro gênero narrativo, também adquiriram funções diferentes ao longo do tempo. Oswaldo Portella, em seu artigo A fábula (1983), publicado na revista Letras, da Universidade Federal do Paraná, ao dar como exemplo uma pequena fábula de Fedro ("Uma montanha, em trabalho de parto, soltava altos gemidos e havia grande grande expectativa na terra: Eis que ela dá à luz um rato."), diz:

Eis uma autêntica fábula esópica que, contada por Esopo, teve a finalidade de
dar um conselho de vida aos ouvintes em geral, contada por Fedro teve a
finalidade de criticar a um contemporâneo seu, e, finalmente, contada por La
Fontaine, possivelmente nos luxuosos salões de Luís XIV, teve por objetivo
divertir e deleitar os cortesãos. Bem por isso, a narrativa para La Fontaine é o
elemento dominante. Somente através de uma narrativa longa pôde o poeta
francês dar rédeas à sua imaginação criadora, ao gosto pelo enfeite e pela
galanteria [...]. (PORTELLA, 1983, p. 122).

La Fontaine foi o grande criador da forma da fábula na literatura ocidental e, dando ênfase especial à narrativa, deixou a lição de moral em segundo plano, de forma que essa ficasse implícita e pudesse ser deduzida pelo leitor, mas sem abandonar por completo seu caráter moralista, que é, segundo Portella, o traço diferencial desse gênero literário: “Sob o aspecto da moralidade, situa-se a fábula entre o provérbio e a anedota. O provérbio é só moralidade, ao passo que a anedota é só narrativa. A fábula contém ambos, sob o manto de uma alegoria" (PORTELLA, 1983, p. 123).

No Brasil, temos como representante célebre do gênero o escritor Monteiro Lobato, que em alguns livros da série Sítio do pica-pau amarelo, como Fábulas de Narizinho (1922, incluído posteriormente em Reinações de Narizinho, de 1931) e Fábulas (1922), reconta fábulas clássicas dos autores supracitados, além de narrar outras de sua própria autoria, como forma de preparar as crianças para a vida em sociedade, seguindo os preceitos morais vigentes. Mais tarde, na década de 1960, Millôr Fernandes também se rende ao gênero, publicando Fábulas fabulosas, em 1964, que faz críticas políticas e sociais com metáforas alegóricas, humor e sarcasmo.

A fábula tende a se passar em um ambiente conflituoso, para pôr o comportamento das personagens à prova em situações dramáticas, em espaço e tempo indeterminados. É comum que se estabeleça o tempo da narrativa com indicações como "um belo dia", "certa vez" etc., para que a história possa servir para qualquer época e lugar. Quanto ao uso de animais antropomorfos nas narrativas, Portella justifica com duas razões: a primeira é que as fábulas trariam "verdades camufladas", pois a verdade nua e crua e a crítica direta 
nunca são bem recebidas pelos leitores ou ouvintes delas. Se essa verdade é destilada da boca de um animal irracional, no entanto, não atinge o homem tão direta e abertamente, ele não se nega a ouvi-las, mas "aos poucos, elas agem sobre seu subconsciente e, quando o homem menos espera, está frente a frente com ela" (PORTELLA, 1983, p. 126); o segundo motivo, que justifica a preferência de animais em detrimento de objetos inanimados, por exemplo, é o

\begin{abstract}
fato de que seus caracteres, qualidades e temperamento são sobejamente conhecidos, não sendo então necessária a prévia descrição desses animais. Ao tomarmos, por exemplo, como personagem de uma fábula o Lobo, sabemos de antemão que se trata de um personagem de caráter prepotente, voraz, antissocial, etc. [...] Tais associações entretanto não se fundamentam em conhecimentos científicos, mas apenas na observação popular. Para uma fábula é indiferente se certas qualidades atribuídas aos animais têm base científica ou não. Nem mesmo é necessário que tais associações sejam universalmente conhecidas. (PORTELLA, 1983, p. 135-6).
\end{abstract}

Portella afirma, ainda, que determinado animal não vai representar sempre o mesmo conjunto de características e o que vai determinar a personalidade daquela personagem é, na verdade, o contexto da narrativa, as relações sociais e o conflito ali presente. Em termos de tradução, o texto possuir elementos fabulescos determinou, em muito, nossa estratégia e no capítulo seguinte mostraremos com exemplos práticos de que maneira isso aconteceu.

\title{
2.4 Desafios de tradução de um texto transgressivo
}

\subsubsection{A oralidade na narrativa}

Dentre os vários desafios que o texto transgressivo propõe para a tradução, a oralidade na narrativa configura um dos mais importantes, abrangendo tanto aspectos linguísticos, quanto narrativos e estilísticos, quanto socioculturais. É um recurso literário comum, notável em grandes clássicos da literatura em língua inglesa, como The adventures of Tom Sawyer (1876), de Mark Twain, e Ulysses (1922), de James Joyce, além de muitos dos outros títulos já mencionados aqui, caso de Naked lunch (1959), William S. Burroughs, e Traispotting (1993), de Irvine Welsh. Com os textos de Chuck Palahniuk, a situação não é diferente: a linguagem oralizada, em tom confessional, de quem narra uma história em situação informal, é uma das principais características da escrita do autor, estando particularmente presente em dois dos textos que escolhemos traduzir, "Knock-knock" e "Loser".

Para tentar entender de que maneira e com qual objetivo a fala se mistura ao texto escrito, temos como base os estudos do Prof. Dino Preti, reunidos em sua obra Estudos 
de língua oral e escrita (2004). Preti afirma que, ao longo da história, a literatura tem servido de corpus para inúmeras pesquisas linguísticas e supre, "muitas vezes, a falta de documentação gravada (que não existia, até recentemente) para registrar variantes da modalidade oral da língua, testemunhando (por escrito), como as pessoas falavam, nas mais variadas situações de interação" (2004, p. 118). Os marcadores conversacionais não são, portanto, uma novidade na literatura: na narrativa medieval já podemos notar a influência do oral sobre o escrito, considerando que o objetivo de muitos desses textos era a leitura em voz alta para grupos de ouvintes (2004, p. 118).

Nas últimas décadas, os estudos da língua oral têm sido ainda mais valorizados, com o surgimento de novas áreas para a sua análise em campos como Análise do Discurso e Sociolinguística. Na literatura, há uma tendência ainda maior de se aceitar o elemento oral e dialetal, pois ele costuma fazer parte da composição da personagem e dar um tom mais realista à sua voz. É claro que também devemos aceitar que a escrita não pode ser uma reprodução fiel e absoluta da fala, pois ela é limitada por diversos fatores, entre eles a necessidade de linearidade dos acontecimentos, para que o texto seja conciso e faça sentido, enquanto muitas vezes, em uma conversa, há mudança contínua de tópico, os falantes podem ser interrompidos por elementos externos e assim por diante (PRETI, 2004, p. 121). Ultrapassar essas barreiras do discurso para recriar um texto convincente vai depender das habilidades narrativas do autor.

Mais à frente em seu livro, Preti cita alguns recursos que podem ser usados pelo autor literário para oralizar seu texto, e são eles:

a) A repetição: muito comum em uma conversa, pode aliviar a densidade das informações e contribuir para o envolvimento entre os interlocutores. Na escrita, se ela for usada com cuidado para fins intencionais de estilo, pode conferir um ritmo à prosa que se assemelha àquele da língua falada;

b) Os marcadores conversacionais: uma técnica da narrativa para envolver o leitor, simulando uma história oral. Alguns deles são bom, pois é, então, daí então, veja, certo, bem, eu acho etc.

c) As estruturas sintáticas: os escritores podem tentar reproduzir a estruturação da língua falada por meio de frases curtas, interrupções no meio das sentenças (seja para que outro personagem comece a falar ou quando a personagem percebe que seu ouvinte já entendeu a mensagem), ausência de estruturas subordinadas complexas, frases justapostas, períodos simples, entre outros mais. 
d) O léxico: é uma característica comum dos autores que buscam recriar a fala popular, o uso de vocábulos ligados à fala simples, do dia-a-dia. Os adjetivos são simplificados e coloquiais (infeliz, vagabundo, safado, otário) e faz-se o uso intensivo da gíria, um elemento de autoafirmação social de determinado grupo.

Acontece que, mesmo quando os autores se valem desses e outros recursos e conseguem atingir um nível satisfatório de oralidade em seus textos, estão sujeitos à crítica e à má aceitação desse elemento textual. Em A tradução literária (2012), Paulo Henriques Britto faz uma reflexão sobre a tradução do diálogo que pode ser útil para lidar com desafios dessa natureza. Ele comenta que, por anos, ao ler tanto os originais de textos em inglês quanto suas traduções em português, incomodou-se com o fato de, na maioria das vezes, as marcas de oralidade, associadas à forma popular da língua, serem ignoradas e os tradutores fazerem o uso da norma padrão, como se o modo como a personagem fala não fosse representativo de sua cultura e, portanto, elemento fundamental do texto literário.

O registro escrito em língua portuguesa é muito menos tolerante perante coloquialismos e uso informal da palavra do que outros idiomas, como o inglês. Britto acredita que

[...] o fenômeno se deva às maneiras opostas como os falantes do inglês e os
do português encaram (ou, ao menos até recentemente, encaravam) seus
respectivos idiomas. De modo geral, para o anglófono, a língua pertence a seus
falantes; a função dos dicionários é registrar as palavras que vão surgindo [...],
as gramáticas inglesas se dedicam mais a registrar do que a julgar. É claro que
há uma norma culta, só que ela é vista como algo que se aplica apenas aos usos
mais formais da língua [...] A atitude tradicional dos brasileiros em relação à
língua portuguesa é muito diferente [...] Ela não pertencia a nós, brasileiros
comuns; pertencia aos portugueses, ou talvez aos grandes escritores
portugueses mortos há no mínimo meio século, ou aos gramáticos e
lexicógrafos e professores de português, aos quais cabia a tarefa de preservá-
la em seu estado de pureza original. (BRITTO, 2012, p. 83-4).

Há de se questionar a fundamentação de tal afirmação de Britto pois, se considerarmos a língua francesa, por exemplo, ela sempre pertenceu aos franceses e, ainda assim, permanece até hoje uma atitude de preservação da língua. Ainda que não saibamos a razão para o brasileiro lidar com o português de forma tão conservadora, porém, o resultado dessa visão tradicionalista é a predominância de diálogos inverossímeis nos textos traduzidos, um afastamento da linguagem falada pelo medo que os autores têm de "escrever errado" e sofrer acusações dos defensores da pureza.

Tal empreitada, no entanto, não deveria representar um desafio moral tanto quanto um desafio linguístico; a própria literatura brasileira está repleta de autores que se 
apropriam da linguagem das mais diversas formas, seja com marcas de oralidade, marcas dialetais, neologismos etc., como mostra Guimarães Rosa em suas obras Grande sertão: veredas (1956) e Primeiras estórias (1962), e que também lidam com objetos escandalosos, falam de fezes, menstruação, esperma, tumores, todo tipo de sexualidade, morte, entre outros temas incômodos que mostram um lado desagradável do ser humano, caso, por exemplo, de Rubem Fonseca em Secreções, excreções e desatinos (2011) e Axilas e outras histórias indecorosas (2011), bem como de Dalton Trevisan em Cemitério de Elefantes (1964).

Isso mostra que há, sim, um leitorado para obras dessa natureza no Brasil, entretanto, quase tudo que se escreve em português, mesmo que do mais baixo calão, é pouco ousado em termos de linguagem. Parece faltar ao tradutor e ao editor da obra superarem esse medo, que pode estar ligado à dificuldade de se definir um local de fala na língua portuguesa para determinada tradução que não torne o discurso da personagem traduzida demasiado regional, com gírias e expressões que impliquem um gentílico que não lhe convém. Essa questão, porém, requer mais análise para que se possa afirmar com categoria como acontece a tradução de obras transgressivas no país.

\subsubsection{A tradução do humor}

O senso de humor ácido é certamente outro dos traços mais marcantes da obra de Palahniuk. Stephen Powers, no livro Make 'em laugh!: American humorist of the 20the 21 st centuries, dedica uma das entradas ao autor e garante que

$$
\begin{aligned}
& \text { [...] seu sucesso duradouro fez com que se tornasse uma figura importante da } \\
& \text { literatura e da comédia norte-americanas. O humor negro de Palahniuk } \\
& \text { certamente se encaixa em espírito com o trabalho de outros humoristas (tanto } \\
& \text { literários quanto performáticos) que confrontam duras verdades e a fragilidade } \\
& \text { do corpo humano de uma forma perturbadora, porém engraçada. (JARVIS, } \\
& 2015 \text {, p. 26. Tradução nossa) }{ }^{42} \text {. }
\end{aligned}
$$

Nos contos traduzidos aqui, esse humor atua sutilmente por meio da ironia e da sátira, zombando de estereótipos, como o do adolescente alienado em "Loser", ou fazendo referências a personalidades da cultura popular norte-americana, como as Kardashians e os Baldwin mencionados em “Zombies”. É somente em "Knock-knock”, no entanto, que o humor se torna elemento central do texto. Tratando-se de uma personagem que tenta salvar o pai da morte com piadas chulas que este passou a vida contando, a tentativa de

\footnotetext{
42 " [...] his lasting success has turned him into a significant figure in American literature and humor. Indeed, Palahniuk's dark humor meshes in spirit with the work of other humorists (both literary and performance based) who confront dark truths and the fragility of the human body in a disturbinf but humorous way." (JARVIS, 2015, p. 26).
} 
fazer rir é crescentemente constrangedora e desconfortável, pondo ainda mais em evidência a sensibilidade dramática do texto. As piadas, no caso, representam um desafio de tradução pois, muito mais do que um conjunto de palavras, elas carregam sentidos socioculturais muito específicos de seu lugar de origem que são a razão de sua graça, que muitas vezes está situada no significante, e, caso não encontrem no contexto de chegada significado equivalente para que sejam compreendidas, perdem seu efeito cômico e, logo, falham em seu objetivo de fazer rir.

Sobre a tradução do humor, Bianca Queiroz confirma nossa suposição ao afirmar, em seu artigo Tradução de humor: limites e possibilidades (2007), que

\begin{abstract}
A finalidade da piada tem sido a mesma nas diversas culturas: causar graça. Sendo assim, podemos ser levados a concluir que o gênero é universal. No entanto, uma vez que todo e qualquer texto é permeado de traços culturais da comunidade onde está inserido, não seria diferente com textos desse gênero. $\mathrm{O}$ fato de um texto ser intimamente ligado ao contexto linguístico-cultural dificulta o processo tradutório, pois quanto mais depender desse contexto na língua-fonte, menos facilmente transferível será para outra língua-cultura. Dessa forma, nem sempre é possível manter o efeito desejado na tradução de textos humorísticos [...] [enquanto em outros casos] percebemos que a situação pode ser adaptada a fim de alcançar um efeito similar. (QUEIROZ, 2007, s.p.).
\end{abstract}

Queiroz sugere, então, que a melhor forma de traduzir piadas seria por meio de uma "tradução de equivalência dinâmica", como a defendida por Nida (1964), também chamada de "translação" ou "tradução funcional" (ROSAS, 2002). Seu princípio seria o de buscar reproduzir no receptor final uma resposta semelhante à dos receptores iniciais, havendo maior preocupação com o efeito do que com a forma do texto, e que resultaria em uma tradução fluida e natural.

A pesquisadora não é a única a se posicionar dessa forma: Marta Rosas, em sua obra Tradução do humor: transcriando piadas (2002), que foi, diga-se de passagem, o primeiro livro teórico a contribuir com o estudo da tradução de textos humorísticos em uma área acadêmica onde, até então, só havia se produzido esporádicos artigos científicos acerca do tema, também defende a adoção de uma "abordagem funcionalista - e, portanto, pragmática - da tradução" (ROSAS, 2002, p. 45). Nessa abordagem, que preza pela reprodução do efeito de prazer e divertimento pretendido pelo texto cômico de origem, bem como de uma reação no receptor final análoga à do receptor inicial, em detrimento de uma fidelidade formal ao texto de partida, a autora aproxima a tradução de piadas à tradução de poesia e confere ao tradutor o papel de recriar o texto. Seria aceitável, 
portanto, que o tradutor "traísse" conscientemente aspectos culturais e linguísticos do original, uma vez que "em tradução o fim justifica os meios" e o máximo que se pode exigir da tradução é que ela tente se manter o mais próximo possível do texto de partida (ROSAS, 2002, p. 47-52).

Isso é o que já defendia John Schmitz em seus artigos publicados ainda em 1996 e 1998 na revista TradTerm, da USP. Na publicação de 1996, Humor: é possível traduzilo e ensinar a traduzi-lo?, ele responde que sim, mas em termos, pois ao passo que há piadas cujo humor se baseia em contextos ou situações que não apresentam grandes problemas para a tradução, há vezes que o humor se origina de uma ambiguidade semântica, sintática, fonológica etc., que pode acarretar problemas e dificuldades de tradução. Sua teoria é de que

Para elaborar uma tradução na qual o humor do original é mantido, seria necessária uma reestruturação básica junto com uma dose de criatividade por parte do tradutor. [...] No caso da tradução de piadas e outros textos humorísticos de determinada língua-fonte para uma língua-alvo, o essencial é reconstruir ou recriar um efeito humorístico da própria língua-alvo, ainda que haja mudanças mínimas ou mesmo drásticas na própria língua de chegada. [...] Essa postura conduz em certos casos até uma troca de piada, especialmente quando o tradutor não encontra recursos adequados na língua de chegada. (SCHMITZ, 1996, p. 92).

Em 1998, em Sobre a tradução e o ensino: o humor levado a sério, Schmitz reforça essa ideia e acrescenta que pode acontecer, sim, de uma piada ser intraduzível e, sendo esse o caso, o tradutor deve abraçar sua liberdade de recriar essa piada da forma que achar mais adequada, ainda que o resultado seja "outra" piada "com grande probabilidade de homônimos diferentes com a mudança do script. Afirma, ainda, que "é com a tradução deste tipo de piada que o tradutor fatalmente será 'infiel', mas esta infidelidade de nenhuma maneira deve ser interpretada como uma desgraça" (RAJAGOPALAN, 1997, apud SCHMITZ, 1998, p. 52), pois o texto original não é sagrado. Foi essa tradução criativa e funcional que buscamos aplicar às piadas de "Knockknock", e à tradução dos textos como um todo, uma vez que, em geral, demos preferência ao conteúdo, em detrimento da forma, como veremos no Capítulo 3. 


\title{
2.4.3 Referências culturais: como lidar com elas?
}

Em se tratando de textos literários, há muitos elementos envolvidos no processo de sua elaboração que representam desafios no momento da tradução. Podemos citar a presença de figuras de linguagem, ritmo, rimas (seja na poesia ou na prosa), elementos imagéticos e de construção do ambiente narrativo, como referências sutis a cores e aromas, entre outros. De todos os elementos que poderíamos trazer à tona, porém, os que costumam se mostrar mais problemáticos são as marcas de oralidade ou dialetais, como já mencionamos anteriormente, e as referências de cunho cultural.

Ritva Leppihalme lida com este último fator em seu livro Culture Bumps (1997) e diz que

\begin{abstract}
a traduzibilidade de um texto depende de até que ponto o texto está 'imerso em sua própria cultura específica' e também quão longe, com relação a tempo e espaço, estão os receptores do TF [texto-fonte] e do TA [textoalvo]. [...] Se a tradução é vista como uma forma de comunicação intercultural, as duas partes do processo de tradução - o tradutor que produz o TA e o receptor que o lê - merecem atenção. (LEPPIHALME, 1997, p. $4-5$, tradução nossa) ${ }^{43}$.
\end{abstract}

Encontramos mais uma vez no texto de Britto, sugestão de como essa tarefa de dar atenção às duas culturas poderia ser realizada. Valendo-se das ideias do teórico, tradutor e poeta francês Henri Meschonnic, ele considera como uma boa saída para o tradutor literário o princípio de se "traduzir o marcado pelo marcado, o não marcado pelo não marcado" (2012, p. 67), o que significa basicamente que

\begin{abstract}
a todos aqueles elementos do texto original que um leitor nativo consideraria convencionais e normais devem corresponder, na tradução, elementos encarados do mesmo modo pelos leitores da língua-meta. Por outro lado, toda vez que o autor do original utiliza algum recurso inusitado, destoante, desviante, que chama a atenção do leitor - é o que estamos chamando de "marcado" -, cabe ao tradutor utilizar, na tradução, algum elemento que suscite no leitor nativo da língua-meta o mesmo grau de estranhamento, nem mais, nem menos, que a passagem original provocaria no leitor da língua-fonte. Não cabe ao tradutor criar estranhezas onde tudo é familiar, tampouco simplificar e normalizar o que, no original, nada tem de simples ou de convencional. (BRITTO, 2012, p. 67).
\end{abstract}

Partindo dessa afirmação, buscamos mais uma vez o conceito de tradução funcional defendido por Schmitz (1996 e 1998), Rosas (2002) e Queiroz (2007) para tradução de textos humorísticos, mas que acreditamos se aplicar a tradução como um todo. Esse conceito, como Queiroz mesmo explica, foi proposto por Eugene Nida, ainda em 1964: ao abordar os tipos de tradução, o autor aponta uma tradução voltada para o

\footnotetext{
${ }^{43}$ Do original: "the translatability of a text depends on the extent to which the text is 'embedded in its own specific culture' and also on how far apart, with regard to time and place, the ST and TT receivers are. [...] If translation is seen as a formo $\mathrm{f}$ intercultural communication, both partners in the translation process - the translator who produces the TT and the receiver who reads it - desserve attention."
} 
texto de partida, com equivalência formal, e uma voltada para o texto de chegada, com equivalência dinâmica. Enquanto a equivalência formal tenta reproduzir a estrutura e unidades gramaticais do original, ou seja, sua forma, a equivalência dinâmica busca fazer com que a tradução soe natural, como se o texto tivesse sido escrito naquela língua, tornando invisível o tradutor.

Nenhuma das duas formas cabe em nosso projeto de tradução, e até mesmo Nida admite não haver apenas esses dois procedimentos possíveis, uma vez que a tradução depende (i) da natureza da mensagem, (ii) do objetivo do autor e do tradutor e (iii) do público-alvo (NIDA, 1964, p. 142), havendo vários tons de cinza entre eles. O que podemos, no entanto, aproveitar da equivalência dinâmica de Nida, é o fato de ser voltada para a resposta do receptor, preocupando-se em reproduzir a reação que o leitor original teve. É claro que isso também não se aplica, exatamente da maneira proposta por ele, à tradução que pretendemos fazer, considerando que o leitor do texto original, apesar de poder ser chocado por seu conteúdo, tem relação de familiaridade com a língua na qual ele é escrito e suas referências culturais, ao passo que para o leitor da tradução que sugerimos, a reação, em alguns momentos, será de estranhamento perante essa cultura e de reconhecimento que o texto não foi originalmente escrito na língua em que ele lê, visto que almejamos deixar claro que se trata de uma tradução.

Outro debate exaustivo da teoria da tradução que tem a ver, direta e indiretamente, com a cultura é o da tradução de nomes próprios, títulos de obras, programas, novelas, filmes, lugares, entre outros, que não tenham ainda tradução reconhecida na língua de chegada. Pesquisadores tentam constantemente encontrar e sugerir a melhor saída para lidar com estes nomes que podem ou não influenciar a compreensão do texto. Na maioria das vezes eles são carregados de significados culturais, um pesadelo para os tradutores que tentam transpor os mesmos conceitos e referentes do texto de partida ao texto de chegada e que são, por diversas vezes, frustrados por barreiras linguísticas e culturais da língua-alvo. Traduzi-los ou substituí-los por algo semelhante na cultura-alvo, na ficção, pode ser uma estratégia perigosa, pois corre o risco de descaracterizar a personagem e provocar uma ruptura com as referências culturais do texto, ao mesmo tempo que deixar de traduzir pode implicar na perda de uma informação importante pelo leitor.

Peter Newmark, em seu livro A Textbook of Translation (1988), diz que todo elemento de um texto é um elemento real, mesmo que apenas naquele universo. Dessa forma, os nomes dados a pessoas, lugares, objetos e termos geográficos, mesmo quando completamente fictícios, podem ser carregados de conotação (marcados) e, nesse caso, 
devem ser traduzidos (1988, p. 214). Por outro lado, se o nome não tiver importância significativa (não-marcado) para a história deve permanecer como no original (1988, p. 214).

Theo Hermans, em seu artigo On Translating Proper Names, with reference to De Witt eand Max Havelaar, de 1988, divide os substantivos em duas categorias: substantivos convencionais e substantivos carregados de significado. Os convencionais não motivariam uma tradução por não possuírem carga semântica aparente e também não é preciso adaptar sua fonética, pois muitas vezes o nome já adquiriu reconhecimento internacional. Os substantivos carregados são aqueles que motivam sua tradução, afetam a interpretação do texto e podem ser fictícios ou reais, contanto que tenham carga histórica e cultural dentro de seu contexto.

O teórico belga sugere pelo menos quatro maneiras de transferir esses substantivos de uma língua a outra: (a) copiá-los, ou seja, reproduzir na tradução exatamente o mesmo termo do texto de partida; (b) transcrevê-los, adaptando a fonologia e a grafia das palavras para que soem melhor na língua alvo; (c) no caso de substantivos convencionais, substituí-los por outros na língua alvo que também não possuam carga semântica; e, no caso de substantivos carregados, tentar traduzir o termo e seu referente (1988, p.13).

No que diz respeito ao processo tradutório como um todo, Peter Newmark acredita que ele seja operacional e que dependa da abordagem que o tradutor do texto escolhe adotar. O tradutor teria em mente quatro níveis, conscientes ou não, que aplica à sua prática: (a) o nível da linguagem fonte do texto, de onde o tradutor parte; (b) o nível referencial, de objetos e eventos que devem ser construídos para o processo de compreensão do texto e, depois, reconstruídos para o processo de reprodução; (c) o nível de coesão, geral e gramatical, que marca a linha de pensamento e o "tom" que percorrem o texto fonte; e (d) o nível de naturalidade da língua do escritor ou enunciador, apropriada para cada situação, o momento em que o tradutor deve buscar o equilíbrio entre a voz do autor e a naturalidade do texto na língua de chegada. A tradução como unidade depende da combinação desses quatro níveis em todo o texto, e não apenas em frases isoladas.

Dessa forma, uma vez que nossa função enquanto tradutores é a de traduzir palavras que fazem parte de um texto (mesmo que o texto seja apenas a própria palavra), é necessário estar atento ao seu contexto sintático, pragmático, cultural, idiomático, entre outros. Por esse motivo, diz Newmark (1988, p. 80), não se pode ir muito longe na tradução ou ampliar demais o significado da palavra para não ameaçar seu significado no contexto original. Seria este o caso de palavras com mais de um referente, que exigem o 
dobro da atenção do tradutor no momento de compreender qual está sendo usado naquele texto e passar a mensagem da forma mais correta possível.

No entanto, há de se lembrar que toda comunicação é, também, uma forma de tradução. Haroldo de Campos comenta em sua obra Transcriação (2013), que "se a tradução é uma forma privilegiada de leitura crítica, será através dela que se poderão conduzir outros poetas, amadores, e estudantes de literatura à penetração no âmago do texto artístico" (CAMPOS, 2013, p. 17), ou seja, o traduzir é ato de criação e também de crítica, portanto a criação de um texto literário é resultado da tradução crítica do autor de sua visão de mundo. O tradutor desse texto estaria, pois, traduzindo uma tradução que interpretou com base em todo um contexto sociocultural em que se insere, imprimindo ali também a sua visão crítica de mundo através do ato criativo que constitui seu ofício. Dessa forma fica difícil julgar se uma tradução está agindo corretamente com o texto original ou mesmo imaginar de que modo o tradutor deveria se portar diante do texto para ser correto, se é que existe (ou deveria existir) tal possibilidade.

Levando em conta tudo o que foi dito até aqui, apresentaremos no próximo capítulo nosso projeto de tradução e estratégias que o constituem. Consideramos cada um dos autores mencionados para compor uma proposta de tradução que acreditamos servir aos propósitos da ficção transgressiva enquanto gênero e dos contos traduzidos enquanto obra, visto que eles têm função de entreter e é preciso pensar neles também como produtos para um público alvo. Após apresentar esse projeto, forneceremos exemplos para ilustrar nossas afirmações e para mostrar como superamos os desafios de tradução discutidos ainda nesse capítulo. 


\title{
CAPÍTULO 3
}

No capítulo anterior, foi possível discutir um pouco e de forma mais teórica as dificuldades e desafios que encontramos durante as traduções que serão apresentadas aqui, e nesse capítulo pretendemos mostrar como se deu esse projeto de tradução na prática, buscando justificar nossas escolhas com os fatores que influenciaram cada decisão e ilustrar com exemplos as estratégias que julgamos melhor atenderem às exigências desses contos. Nosso objetivo foi criar uma tradução que ponha em evidência a cultura do outro, sua poética e escrita transgressiva, e que cause estranhamentos e levante questionamentos sobre a nossa própria sociedade, a partir das críticas da sociedade norte-americana.

A tradução deve funcionar como uma ponte que transpõe barreiras geográficas e culturais, provocando encontros que põem frente à frente o que é familiar e o que é estranho e transgressivo, além de ser fonte de conhecimento para os leitores acerca de determinado povo, portanto, faz-se necessário que ela se posicione como tradução, assumindo-se texto de outra origem, de outro lugar. Ao mesmo tempo, acreditamos que tal estranhamento atinge mais leitores ao cativá-los (em primeiro lugar, os leitores precisam querer ler o texto) e, portanto, precisa soar o mais fluído possível em português a fim de proporcionar uma leitura confortável. Vale reforçar para que fique claro: defendemos que a linguagem do texto e seu ritmo sejam confortáveis, mas não o conteúdo da obra, seu tema ou suas referências; isso pode e deve, principalmente no caso de textos transgressivos, cumprir seu papel de tirar o leitor de sua zona de conforto.

Adotamos aqui uma postura que condiz com o que Octavio Paz defende em Tradução: literatura e literalidade (2009):

\begin{abstract}
A tradução implica uma transformação do original. Essa transformação não é, nem pode ser, senão literária, porque todas as traduções são operações que se servem dos modos de expressão a que, segundo Roman Jakobson, se reduzem todos os procedimentos literários: a metonímia e a metáfora. O texto original jamais reaparece (seria impossível) na outra língua; entretanto, está sempre presente, porque a tradução, sem dizê-lo, o menciona constantemente ou o converte em um objeto verbal que, mesmo distinto, o reproduz: metonímia e metáfora (PAZ, 2009, p. 15).
\end{abstract}

É disso que se trata: reproduzir o original, suas imagens e mensagens, de forma distinta, com outras cores. Uma saída que consideramos (e veja que não se trata de uma solução, mas uma saída possível, entre outras diversas) para a tradução de elementos culturais é a de propor uma tradução que seja tanto funcional quanto criativa, ou seja, nosso objetivo é recriar (de forma criativa) em português um texto transgressivo que possa 
transportar o leitor à cultura do outro, sem deixar de fornecer a ele uma leitura fluida (que funcione bem em língua portuguesa), como foi dito acima. Ao enxergar a tradução como “comunicação intercultural” (LEPPIHALME, 1997), não é possível aceitar a sugestão de Britto de somente traduzir o "marcado pelo marcado e o não marcado pelo não marcado" (BRITTO, 2012). Se o tradutor aceitar sempre que não cabe a ele criar estranhezas onde tudo é convencional, sua tradução nunca terá a oportunidade de tirar o leitor de sua zona de conforto sociocultural, de transgredir, de mostrar a ele que existe uma outra visão de mundo para, quem sabe, fazê-lo refletir sobre isso. É claro que, como dito anteriormente, essa empreitada se torna mais fácil no caso da tradução entre culturas relativamente próximas, como é o Brasil, que, no contexto do polissistema literário ocidental, é um polissistema periférico fortemente influenciado pelo polissistema dos EUA, que ocupa posição central.

Dessa maneira, podemos justificar nossa decisão de não acrescentar notas de rodapé à tradução, mesmo nos momentos em que surgem referências culturais que dificilmente serão assimiladas de imediato pelo leitor. A literatura de Chuck Palahniuk é uma literatura de entretenimento, que, ao prender a atenção do leitor, tem a oportunidade de despertar nele um senso crítico, uma reflexão sobre um problema social, cultural, econômico ou qualquer que seja, e a quebra de fluidez da leitura ocasionada pela presença de notas de rodapé dificulta que esse leitor mantenha o interesse no texto por tempo o bastante para que ele atinja seu propósito.

Além do mais, o próprio autor já disse que escreve como se estivesse contando uma história em um bar, porque de fato se acostumou a ler em bares os contos que escrevia no workshop de escrita criativa que frequentava, como podemos ver nos trechos das entrevistas a seguir:

\begin{abstract}
Chuck tinha seus trinta e poucos anos quando começou a frequentar workshops de escrita criativa. Ele aprendeu a escrever em um bar. Seu professor, Tom Spanbauer, arranjava leituras públicas em bares onde ficam passando esportes. "As pessoas estavam envolvidas com os esportes passando nas televisões ou jogando sinuca, ou pinball ou videogames", diz Chuck. "Eu me lembro de ver amigos meus tentando ler memórias sentimentais que eram tão sutis e sensíveis emocionalmente que eles acabavam chorando de soluçar e ninguém mais dava a mínima. Quando chegou minha vez de ficar de pé ali no bar e ler, eu quis garantir que o que quer que eu lesse chamasse a atenção do bar inteiro, e funcionou". ${ }^{44}$
\end{abstract}

\footnotetext{
44 "Chuck was in his thirties before he started attending creative writing workshops. He learned to write standing on a bar. His teacher, Tom Spanbauer, would arrange public readings in sports bars. 'People were involved in sports on televisions or playing pool or pinball or videogames,' says Chuck. 'I remember seeing friends of mine trying to read heartfelt memoir that was so subtle and emotionally sensitive that they would be weeping and no-one would give a shit. When it came my turn to stand on the bar and read I made sure
} 
"Eu gosto de ir direto ao ponto", ele [Palahniuk] diz. "Eu tento contar uma história que nem alguém te contaria num bar, com a mesma marcação de tempo e ritmo". [...] Dessa forma, um romance de Chuck Palahniuk soa como um filme transcrito no papel. [...] "Tem gente por aí que não lê livros, mas por algum motivo eles leem os meus. Eles satisfazem essas pessoas de uma forma que a maioria das obras de ficção não consegue. Eu dou pra eles um tipo de entretenimento menos filtrado. Eu reconheço partes não reconhecidas das nossas vidas, que, como uma cultura, não costumamos falar a respeito". ${ }^{45}$

Pelos depoimentos do autor, também podemos identificar seu público como sendo composto por pessoas que geralmente não leem livros e, logo, estariam ainda menos dispostas a ter sua leitura interrompida por notas do tradutor ou do editor, por estarem em busca de uma literatura de consumo imediato, que deve ser fluida, assim como afirma Venuti a respeito dos best-sellers em The scandals of translation: towards an ethics of difference (1998). Por fim, o autor também deixa claro nos trechos a importância que dá a cadência e ritmo de suas narrativas, que lê em voz alta com frequência em eventos literários e turnês de divulgação de seus livros. Interromper a continuidade da leitura decerto prejudicaria tal faceta da escrita de Palahniuk, que julgamos mais importante do que esclarecer determinadas referências.

Omitir as referências ou substituí-las por termos mais genéricos e metonímicos também não era uma opção, uma vez que a literatura e sua tradução são uma oportunidade de o leitor enriquecer seu conhecimento acerca de outras culturas e reconhecer o outro enquanto outro. Para que o leitor também não fosse prejudicado e se perdesse em meio a tantos marcadores culturais desconhecidos por ele, no caso de realmente não os conhecer, nossa estratégia foi tentar clarificar de forma genérica e sutil do que se tratava determinada coisa ao longo do próprio texto. Em geral, as notas são consideradas o maior recurso de visibilidade do tradutor, mas, na falta delas, é por meio das alterações que garantimos que o tradutor não será apagado.

Podemos ver um exemplo de como tal feito se dá na prática nos trechos:

a)

\begin{tabular}{|l|l|}
\hline Texto original & Sugestão de tradução \\
\hline
\end{tabular}

that the thing that I read drew the attention of the entire bar, and it worked." Disponível em: http://thequietus.com/articles/15159-chuck-palahniuk-interview-doomed. Acesso em fevereiro de 2017.

45 "' I like to cut to the chase,' he says. 'I try to tell a story the way someone would tell you a story in a bar, with the same kind of timing and pacing.' [...]To this end, a Chuck Palahniuk novel reads like a film transcribed on to the page.[...] 'There are people out there who will not read books, but somehow they'll read my books. They serve them in a way most fiction doesn't. I give them a less filtered form of entertainment. I acknowledge some unacknowledged parts of our lives, which, as a culture, we don't tend to talk about."' Disponível em: https://www.theguardian.com/books/2005/may/08/fiction.chuckpalahniuk. Acesso em fevereiro de 2017. 


\begin{tabular}{|l|l|}
\hline \multicolumn{1}{|l|}{ Instead, she sat in bed, hearing the } & \multicolumn{1}{|c|}{ Ao invés disso, sentou-se na cama, } \\
grunting and rutting through the motel wall and & ouvindo os gemidos e fricções através da parede de \\
pretending to read The Wapshot Chronicle. & $\begin{array}{l}\text { hotel e fingindo ler o clássico A crônica dos } \\
\text { Wapshot, de John Cheever. }\end{array}$ \\
\hline
\end{tabular}

b)

\begin{tabular}{|l|l|}
\hline \multicolumn{1}{|c|}{ Texto original } & \multicolumn{1}{c|}{ Sugestão de tradução } \\
\hline Understand me: My old man is no Uncle & \multicolumn{1}{|c|}{ Olha só: meu coroa não é nenhum Uncle } \\
Milty. He's no Edgar Bergen. & $\begin{array}{l}\text { Milty. Nenhum Edgar Bergen ou qualquer um } \\
\text { desses comediantes. }\end{array}$ \\
\hline
\end{tabular}

São acréscimos sutis, de caráter descritivo, sem efeito significativo na narrativa, que servem para situar o leitor, deixando-o ciente de que The Wapshot chronicle se trata de um clássico da literatura norte-americana e que Uncle Milty e Edgar Bergen são famosos comediantes estadunidenses. Ir além disso e descobrir o enredo do livro e dados adicionais, ou aprender sobre a vida dessas celebridades da arte cômica, fica por conta do leitor, que, com o advento da internet, possui hoje ferramentas de pesquisa de facílimo acesso. Note que nossa estratégia, no que se refere a elementos culturais, é a de "traduzir o marcado pelo marcado e o não marcado pelo marcado também”, porém modificando o texto criativamente de forma a causar um estranhamento controlado, apresentar algo que ele desconheça, mas em um contexto que possa ter uma ideia geral do que se trata, no mínimo.

Ainda aproveitando o que disse Palahniuk nas entrevistas sobre sua escrita, podemos abordar uma das maiores marcas de sua obra: a oralidade na narrativa, não apenas nos momentos de diálogo das personagens, mas no texto como um todo. Sua obra realmente costuma soa como se alguém estivesse contando uma história em um bar ou em outra situação inusitada e dos quatro contos traduzidos, três deles apresentam tal recurso e tentam, em níveis diferentes, reproduzir uma conversa informal. São eles "Loser", uma narrativa em segunda pessoa, por diversas vezes imprecisa, de um jovem sob efeito de LSD; "Knock-knock", um relato pessoal e emocionado, e talvez por isso atrapalhado em alguns momentos, de um jovem que acaba de perder o pai; e "Zombies", narrativa em primeira pessoa de um jovem em crise de identidade.

Para cada um desses contos foi preciso aplicar um nível conversacional diferente, pois se tratam de vozes de personagens muito distintas, passando por crises e situações extremas de estresse que se refletem em seus discursos. Uma saída que encontramos foi a de ouvir o autor lendo os contos em voz alta em eventos como os que já mencionamos 
(é possível encontrar diversos vídeos de suas leituras no YouTube) e no audiolivro de Make something up (no qual alguns contos, como "Knock-knock", são narrados pelo autor) para então tentar reproduzir em português uma leitura que soasse semelhante.

O texto precisa soar natural e fluido em português - ainda que a oralidade seja assumidamente fingida e genérica - porque é assim que o narrador do original falaria se tivesse voz real, e é assim que o leitor desse texto, muito provavelmente, falaria também se pudéssemos conversar com ele. Sabemos disso por conta o público alvo do autor, em geral jovens, e quanto maior a afinidade desse leitor com o texto, com o narrador, com seu local de fala, ainda que seja um local diferente do seu, quanto mais identificação ele tiver com a situação que vive a personagem, maiores as chances de ele conseguir absorver a crítica que está ali e refletir sobre isso, desenvolver esse pensamento e reproduzi-lo.

Durante a leitura dos contos e, de forma mais pronunciada, durante o processo de tradução, também pudemos notar que o autor utiliza a pontuação com certa liberdade, sem ater-se à normas gramaticais. Há diversas vezes uma sequência de elementos não separados por vírgula, como seria o costume, pontos finais são usados onde vírgulas seriam mais adequadas e usa-se ponto e vírgula e dois pontos de maneira aparentemente arbitrária, como podemos ver na frase seguinte:

Stop me if I already told you this one: but my old man gets that prostrate cancer that's not even like cancer because it takes twenty, thirty years before we even know he's so sick, and the next thing I know is I'm trying to remember all the stuff he's taught me. (PALAHNIUK, 2015, p. 3).

Tais ocorrências são recursos usados para reproduzir essa oralidade fingida sobre a qual já comentamos e nos fazem questionar que atitude tomar quando da tradução, pois, afinal, deveríamos reproduzir a pontuação tal qual estava, mesmo quando empregada de maneira menos usual, ou deveríamos aplicar à pontuação a norma culta do português? Uma terceira via, e a que escolhemos, foi a de não ser nem só uma coisa, nem outra, mas repetir a pontuação menos usual do original para preservar as escolhas do autor e, nas outras ocasiões, utilizar a pontuação a favor da reprodução em português dessa linguagem oralizada, pontuando conforme o texto exigisse para soar conversacional:

Me interrompe se eu já tiver contado essa: mas meu coroa tá com aquele câncer de próstada que num é nem um câncer de verdade porque leva vinte, trinta 


\section{anos até a gente descobrir que ele tá doente desse tanto e minha primeira reação é tentar lembrar de tudo que ele me ensinou.}

Além disso, cabe comentar brevemente nossa decisão de manter as aspas como marcação dos diálogos, ao invés de substituí-las por travessões, como mandam as regras de redação do português padrão. Isso foi uma estratégia para aproximar nossa tradução do conto original, fazendo-o parecer, desde o momento em que o leitor bate o olho na página, antes mesmo de ler, um conto traduzido. As aspas também parecem "casar" melhor com os contos de Palahniuk, em termos de pontuação: como os diálogos são muito frangmentados, interrompidos pela narração diversas vezes, o uso dos travessões que tentamos primeiramente havia deixado o texto muito carregado, por assim dizer. Seria necessário alterar a estrutura dos parágrafos para que a leitura ficasse fluida e não achamos pertinente quando as aspas poderiam, facilmente, manter o texto visualmente estético e marcar com muito mais clareza os diálogos, deixando-os agradáveis de se ler.

Apresentamos, a seguir, nossa proposta de tradução para cada um dos contos, separadamente, de forma a trazer exemplos das maiores dificuldades que enfrentamos e aprofundar as discussões iniciadas nos capítulos anteriores. É preciso deixar claro, antes de mostrar esses resultados, que, de forma alguma, consideramos as soluções encontradas como as melhores ou mais adequadas, mas elas são, conforme nossa interpretação dos contos e conhecimento da obra do autor, o que acreditamos representar Palahniuk em língua portuguesa. Cabe lembrar que não é uma tentativa de soar como se o autor escrevesse em português, como já foi dito anteriormente, mas, muito pelo contrário, de fazer transparecer seu local de fala e os elementos socioculturais de partida em um texto que se porta como tradução (e é nossa intenção que isso fique claro para o leitor) e que almeja, paralelamente, ser fluido e confortável de se ler na língua de chegada.

\subsection{Knock-knock ${ }^{46}$}

"Knock-knock" foi, muito provavelmente, o conto que mais nos trouxe desafios de tradução. Primeiramente, o conto é todo escrito no tom conversacional de quem está contando uma história em uma situação informal: talvez em um bar, como onde o autor disse na entrevista contar suas histórias, talvez na barbearia que a personagem frequenta ou, quem sabe, até mesmo em um sanatório, como resultado do surto psicótico que o

\footnotetext{
${ }^{46}$ Para a tradução e original completos, vide Anexo A (p. 124).
} 
narrador parece ter ao fim do conto. O texto, portanto, é cheio de abreviações, interjeições, frases curtas ou, por vezes, longas e não pontuadas quando o desespero da personagem vai aumentando e seu ritmo narrativo se torna cada vez mais tenso e claustrofóbico. Confirmando os recursos de oralização da narrativa enumerados por Dino Preti (2004) que trouxemos no Capítulo 2, "Knock-knock" apresenta repetição ("But love...I mean you have to love your old man. I mean, after you're born it's not like you get a choice"), marcadores conversacionais (em especial, "so" e "and" no começo das frases) e léxico que recria a fala popular e gírias ("fuck it", "damn", "what the hell”, "bust a gut", "heehaw" etc.), o que, para respeitar nossa estratégia de tradução, deve constar no texto traduzido também.

[1] Como forma de criar um discurso narrativo também oralizado, fizemos escolhas como a de substituir palavras por seu equivalente fonético, em abreviação, como seriam provavelmente ditas em uma conversa em português:

$$
\begin{aligned}
\text { para } & \rightarrow \text { pra } \\
\text { para o } & \rightarrow \text { pro } \\
\text { para um } & \rightarrow \text { prum } \\
\text { não } & \rightarrow \text { num } \\
\text { você } & \rightarrow \text { cê } \\
\text { está } & \rightarrow \text { tá } \\
\text { estou } & \rightarrow \text { tô } \\
\text { em uma } & \rightarrow \text { numa }
\end{aligned}
$$

É claro que não pretendemos afirmar, com isso, que todo falante de português fale assim, mas é uma representação genérica e fingida do português coloquial do Brasil, desconsiderando dialetos, socioletos, sotaques de regiões específicas ou quaisquer outras variações da língua que possam haver e que admitimos serem incontáveis (e isso vale para a tradução de todos os contos da dissertação).

Outro recurso que utilizamos foi o de repetir sempre o pronome pessoal "eu", mesmo quando omiti-lo fosse o mais adequado a se fazer, e de dar preferência a estruturas como "salvar ele" ao invés de "salvá-lo" e "abandonou a gente", ao invés de "nos abandonou". Empregamos, ainda, o uso do aumentativo e diminutivo nas palavras que pediam tal coisa, para soar mais informal, caso de "perucona", ao invés de "grande peruca" para "big wig", "bocetinha", ao invés de "boceta pequena" para "little heinnie", e até mesmo "peitões" e "rabão" para "tits" e "ass", que não estão no aumentativo no 
original, mas em português nos pareceu assim que o sujeito misógino que conta uma piada como a da moça que é estuprada iria se referir aos seios e bunda dela.

Alguns exemplos do resultado final dessa tradução oralizada, seguem:

a)

\begin{tabular}{|r|r|}
\hline \multicolumn{1}{|c|}{ Texto original } & \multicolumn{1}{c|}{ Sugestão de tradução } \\
\hline My old man, he makes everything into a & Meu coroa, tudo pra ele é uma Grande \\
Big Joke. What can I say? The old man loves to get & Piada. Que que eu posso dizer? O cara adora dar \\
a laugh. Growing up, half the time I didn't have a & umas risadas. Quando eu era mais novo, quase \\
clue what his jokes were about, but I laughed & nunca tinha ideia do que as piadas queriam dizer, \\
anyways. Down at the barbershop, it didn’t matter & mas eu ria de qualquer jeito. Na barbearia, não \\
how many guys my father let take cuts ahead of & importava quantos caras meu pai deixava passar na \\
him in line, he just wanted to sit there all Saturday & frente pra cortar o cabelo, ele só queria sentar lá o \\
and crack people up. Make folks bust a gut. Getting & sábado inteiro e matar todo mundo de rir. Fazer o \\
his hair cut was definitely a low priority. & povo gargalhar até explodir. Cortar o cabelo \\
& definitivamente não era prioridade. \\
\hline
\end{tabular}

b)

\begin{tabular}{|l|l|}
\hline \multicolumn{1}{|c|}{ Texto original } & \multicolumn{1}{|c|}{ Sugestão de tradução } \\
\hline Nothing kills a joke like asking my old man & Nada mata uma piada mais rápido do que \\
to explain himself, and lying there in that bed, he & pedir pro meu coroa explicar ela e, deitado ali \\
stops breathing. No heartbeat. Totally flatlined. & $\begin{array}{l}\text { naquela cama, ele para de respirar. Zero } \\
\text { batimentos cardíacos. Uma puta linha reta. }\end{array}$ \\
\hline
\end{tabular}

c)

\begin{tabular}{|c|c|}
\hline & Sugestão de t \\
\hline $\begin{array}{l}\text { What I do know is I've got a brain filled } \\
\text { with jokes I can't ever forget-like a tumor the size } \\
\text { of a grapefruit inside of my skull. And I know that } \\
\text { eventually even dog shit turns white and stops } \\
\text { stinking, but I have this permanent head filled with } \\
\text { crap I've been trained my whole life to think is } \\
\text { funny. And for the first time since I was a Little } \\
\text { Stooge standing in that barbershop saying fag and } \\
\text { cunt and nigger and saying kike, I figure out that I } \\
\text { wasn't telling a joke-I was the joke. }\end{array}$ & $\begin{array}{l}\text { A única coisa que eu sei é que eu tenho uma } \\
\text { cabeça cheia de piadas que eu não consigo } \\
\text { esquecer - tipo um tumor do tamanho duma } \\
\text { laranja no meu crânio. E eu sei que no fim das } \\
\text { contas até cocô de cachorro fica branco e para de } \\
\text { feder, mas eu tenho pra sempre essa cabeça cheia } \\
\text { de merda que fui treinado a vida inteira pra achar } \\
\text { engraçado. E pela primeira vez desde que eu era } \\
\text { um Pateta mirim de pé na barbearia dizendo bicha } \\
\text { e boceta e negro e judeu, eu percebo que eu não } \\
\text { tava contando a piada - eu era a piada. }\end{array}$ \\
\hline
\end{tabular}


[2] Outra grande dificuldade que tivemos foram as piadas contadas ao longo do texto. Como vimos no início desse capítulo, o humor costuma estar intimamente ligado a cultura, a estigmas e preconceitos que a sociedade desenvolve de raças, etnias, grupos econômicos e afins, e é comum que a graça esteja na criação de neologismos ou jogos de palavras que dependem muito da língua em si (significante) para serem cômicos. Nesses e em outros casos, a tradução direta é inviável, fazendo-se necessária uma tradução funcional como a que sugerem Schmitz (1996 e 1998), Rosas (2002) e Queiroz (2007), vistas no Capítulo 2, que já admitimos considerar a melhor opção.

Seguem alguns exemplos das piadas que tivemos que traduzir, com nossas sugestões de tradução:

a) No caso desse primeiro exemplo, apesar de estarmos, desde o início, dispostos a "transladar criativamente", procuramos de toda forma traduzir a anedota sem precisar substituí-la por outra, tentativa que, infelizmente, não foi bem-sucedida:

\section{"Back when I was his little Charlie McCarthy, the whole time I was growing up, he used to ask me, 'Knock-knock?' \\ I'd say, 'Who's there?' \\ He'd say, 'Old Lady...' \\ I'd say, 'Old Lady, who?' \\ And he'd say, 'Wow, I didn't know you could yodel!'”'(PALAHNIUK, 2015, p. 2).}

O grande problema de traduzir literalmente a piada acima é que o narrador comenta ao longo do texto que cresceu acreditando que a "old lady" mencionada na piada é a sua "old lady", no caso sua mãe, que o abandonou quando ele tinha quatro anos. Tratase, portando de um substantivo marcado, cujo sentido modifica o texto. A dificuldade em se traduzir diretamente está no som que "old lady, who?" faz quando pronunciada, que assemelha-se ao do canto tirolês, ou iodelei (algo como "olê-rí-rú"). Em português, "que velha?" não produz esse efeito sonoro de jeito algum. Tampouco é possível, por essa mesma razão, substituí-la por qualquer piada de "toc-toc" já existente em português.

A saída que encontramos foi a de buscar ou criar uma piada de "toc-toc" que utilizasse um nome próprio feminino para representar a mãe do narrador. É, assumidamente, uma estratégia ousada, que interfere e altera o texto drasticamente, uma vez que dá nome à uma personagem que não tem nome, sem o aval do autor. No entanto, foi a única forma que encontramos de manter o efeito cômico (ou tentativa dele), manter 
a conexão entre a piada e a mãe da personagem e, ainda por cima, utilizar uma anedota cuja graça se encontra em um jogo de palavras com ambiguidade fonética.

O que surgiu em nossas pesquisas de mais interessante para esse contexto, foi:

- Toc-toc!

- Quem é?

- É a Paula.

- Que Paula?

— Paula dentro, Paula fora.

No entanto, essa piada tem carga sexual muito explícita e, uma vez que o texto vai associá-la à mãe do garoto mais tarde, não parecia a melhor opção. Tentamos, então, criar uma anedota, e o resultado foi:

\begin{tabular}{|c|c|}
\hline & Sugestão de tradução \\
\hline $\begin{array}{l}\text { Back when I was his little Charlie } \\
\text { McCarthy, the whole time I was growing up, he } \\
\text { used to ask me, "Knock-knock?" } \\
\text { I'd say, "Who's there?" } \\
\text { He'd say, "Old Lady..." } \\
\text { I'd say, "Old Lady, who?" } \\
\text { And he'd say, "Wow, I didn't know you } \\
\text { could yodel!" }\end{array}$ & $\begin{array}{l}\text { Na época que eu era o bonequinho dele, } \\
\text { feito o Charlie McCarthy, o tempo todo enquanto } \\
\text { eu crescia, ele me perguntava, "Toc-toc?" } \\
\text { Eu dizia, "Quem é?", } \\
\text { Ele dizia, "Sophie..." } \\
\text { Eu dizia, "Que Sophie?" } \\
\text { E ele dizia, "Sophie da puta, abre logo essa } \\
\text { porta!" }\end{array}$ \\
\hline
\end{tabular}

Lida em voz alta, ou mesmo pensada, "Sophie da puta" soa como uma forma rápida e resumida de dizer "seu filho da puta", ou "seu 'fi' da puta", como é mais comum ouvirmos em diálogos informais, e é nisso que residiria o humor da piada. É claro que temos que admitir que ela tem uma carga agressiva que a original sobre canto tirolês não tem, mas como há outras piadas no texto de gosto muito mais duvidoso que essa, acreditamos que seja condizente com algo que o pai do narrador contaria achando graça. Além do mais, o jogo de palavras fonético traz tanto um nome de mulher, Sophie, quanto uma ofensa à alguém e/ou à mãe de alguém, com o "seu filho da puta", e tanto "puta" quanto "Sophie" poderiam se referir à mãe do garoto. Não é uma solução perfeita, mas dentre as possibilidades com as quais trabalhamos, consideramos essa a mais adequada. 
b) A segunda piada contada no conto é:

\begin{tabular}{|c|c|}
\hline Texto original & Sugestão de tradução \\
\hline $\begin{array}{l}\text { He used to ask me, "When that Vinnie van } \\
\text { Gogh cut off his ear and sent it to the whore he was } \\
\text { so crazy about, how'd he send it?" } \\
\text { The punch line is "He sent it by 'ear } \\
\text { mail,', but being seven years old, I was still stuck } \\
\text { back on not knowing who van Gogh is or what's a } \\
\text { whore, and nothing kills a joke faster than asking } \\
\text { my old man to explain himself. }\end{array}$ & $\begin{array}{l}\text { Ele vivia me perguntando, "Quando } \\
\text { aquele Vinnie van Gogh cortou a orelha fora e } \\
\text { mandou pra puta que ele amava tanto, como ele } \\
\text { ligou pra avisar?" } \\
\text { A graça da piada era "Ele ligou do } \\
\text { 'orelhão", mas com sete anos eu ainda não sabia } \\
\text { quem é van Gogh nem o que é uma puta e nada } \\
\text { acaba com uma piada mais rápido do que pedir pro } \\
\text { meu coroa explicar ela. }\end{array}$ \\
\hline
\end{tabular}

Aqui a graça e a dificuldade estão no trocadilho fonético feito com as palavras “ear" [orelha] e "e-mail”, que não é possível em português. A solução que encontramos foi alterar levemente a piada para que pudéssemos usar "orelhão" e mantê-la, de certa forma, semelhante ao original. A piada resultante não é completamente outra, pois conseguimos preservar seu tema central (van Gogh corta a própria orelha e a envia para a amante), mas também não é a mesma pois, mais uma vez, o objetivo é produzir riso.

c) Um terceiro exemplo é:

\begin{tabular}{|c|c|}
\hline Texto original & Sugestão de tradução \\
\hline And when he says, "Knock-knock..." & E quando ele diz, "Toc-toc..." \\
And I say, "Who's there?" And he says, & E eu digo, "Quem é?" E ele diz, "Fifi". \\
"Radio." & E eu digo, "Que Fifi?" E ele JÁ tá se \\
And I say, "Radio who?" And he’s & contorcendo de rir quando diz, "Fifica esperto que \\
ALREADY started to bust a gut when he says, & eu vou gozar na sua boca..." \\
"Radio not I'm going to cum in your mouth..." & \\
\hline
\end{tabular}

Trata-se de mais uma piada de "toc-toc", mas dessa vez seu sentido não tem ligação direta com nenhum elemento do texto, portanto foi possível traduzi-la de forma a conservar sua estrutura e humor, mas com a liberdade de substituir "radio" e "radio not" por qualquer outra palavra ou combinação de palavras que coubesse nesse contexto, sabendo que o objetivo era que ela acabasse com algo ou alguém gozando na boca do ouvinte. Já que não chegou a nosso conhecimento uma anedota equivalente a essa em português, criamos três opções de tradução: 
1) - Toc-toc!

—Quem é?

- É a Fifi.

— Que Fifi?

- Fifica esperto que vou gozar na sua boca.

2) - Toc-toc!

—Quem é?

- É a Cipre.

— Que Cipre?

- Cipre para que vou gozar na sua boca.

3) - Toc-toc!

-Quem é?

- É o Jacinto.

— Que Jacinto?

— Jacinto que vou gozar na sua boca.

A terceira opção foi imediatamente descartada por Jacinto ser um nome brasileiro e se distanciar demais da cultura de partida, a qual procuramos manter. A escolha final por Fifi, em detrimento de Cipre, deu-se ao levarmos em conta que Fifi é um apelido que de fato existe em língua inglesa e em português, portanto soaria mais legítima e atenderia à nossa estratégia de tradução.

d) O próximo exemplo é, com toda certeza, a piada mais ofensiva, mais asquerosa e de mais mau gosto de todo o conto:

\begin{tabular}{|r|r|}
\hline Texto original & Sugestão de tradução \\
\hline The son looks into his old man's pale, & Daí esse filho crescido entra no quarto da \\
dying face and says: "So this blond gal walks into & casa de repouso do pai, puxa uma cadeira ao lado \\
a neighborhood bar where she's never been before, & da cama e senta. O filho olha pro rosto pálido e \\
and she's got tits out to HERE and a tight little & mórbido do seu coroa e diz, "Daí essa mina loira \\
heinie and she asks the bartender for a Michelob, & entra num bar que ela nunca foi antes e ela tem \\
and he serves her a Michelob, except he sneaks a & umas tetas até AQUI e uma bocetinha apertada e \\
Mickey Finn into her bottle and this blonde goes & ela pede uma Budweiser pro garçom e ele serve a \\
unconscious, and every guy in the bar leans her & Budweiser só que coloca um Boa-noite-Cinderela \\
over the edge of the pool table and hikes up her & na garrafa sem ela ver e a loira apaga e todos os \\
skirt and fucks her, and at closing time they slap & caras no bar botam ela na mesa de sinuca, levantam \\
\hline
\end{tabular}




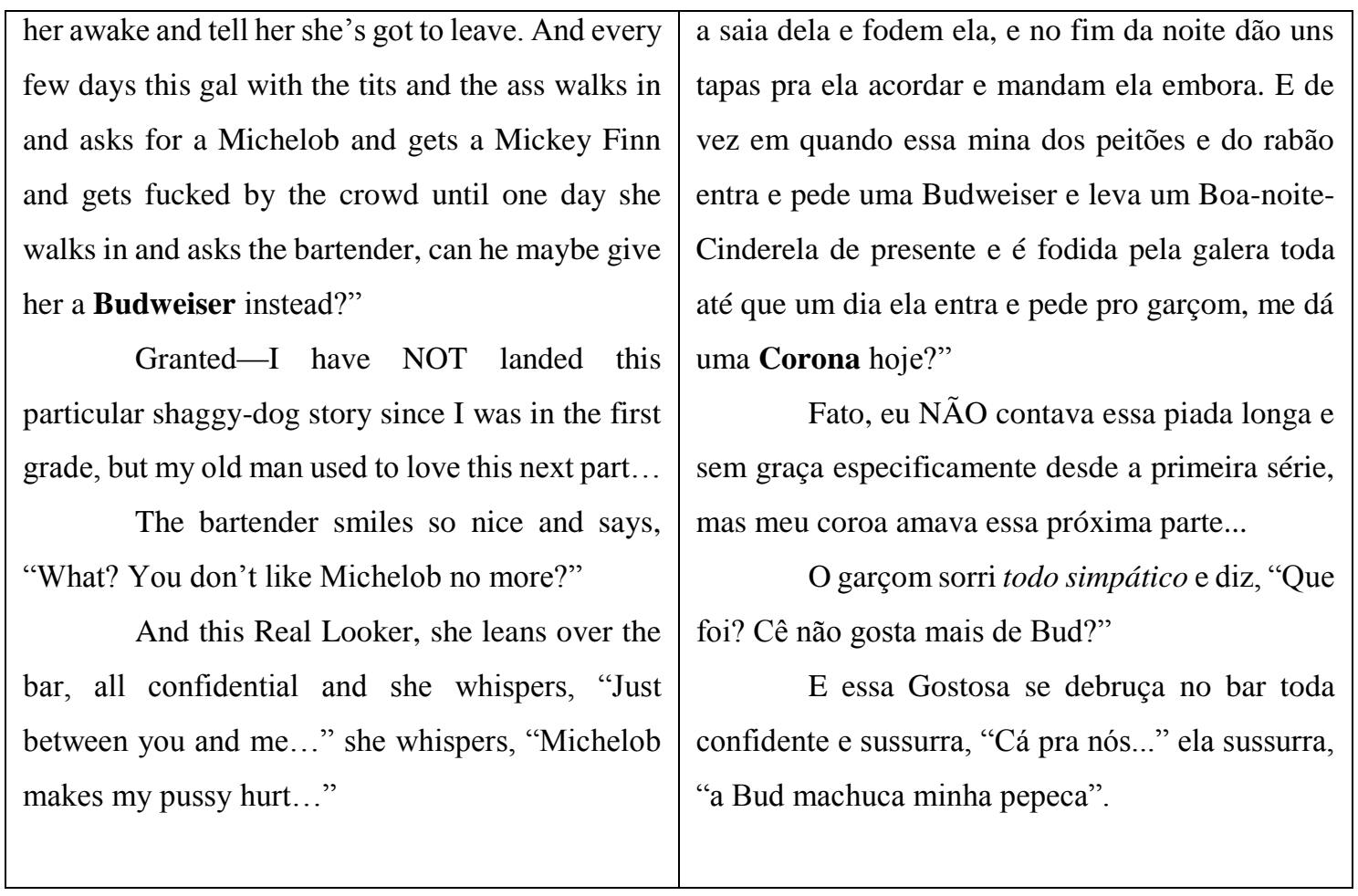

A primeira coisa que tivemos que fazer ao traduzir essa piada foi reprimir a vontade de substituí-la por completo por outra que não fosse covarde, machista e misógina. Não cedemos a esse impulso porque, antes de mais nada, é uma piada que, por mais horrível que seja, diz muito sobre a personagem do pai, que é machista e de caráter duvidoso. Mas não apenas sobre a personagem: ao pesquisar piadas em português na internet, deparamo-nos com uma infinidade de piadas sexistas, machistas, abusivas e preconceituosas das mais diversas formas, o que serve para mostrar que o norteamericano e o brasileiro (falamos desses dois povos por não termos pesquisado em outras sociedades, mas é muito provável que poderíamos ir ao ponto de dizer "o ser humano") continua achando graça e reproduzindo piadas degradantes sobre minorias políticas. E isso é algo que está tão enraizado em ambas as culturas que é visto como "só uma piada" e "só uma brincadeira".

Mas não é, e essa visão tem sido (muito) lentamente desconstruída nos últimos anos, em especial com a ascensão de movimentos politizados que encontraram voz nas mídias sociais. Em se tratando do estupro especificamente, em 2012, quando o comediante norte-americano Daniel Tosh, ao ser interrompido por uma mulher na plateia que não gostou da piada que ele acabara de fazer, sugeriu que seria engraçado se ela fosse 
estuprada por cinco homens naquele exato momento ${ }^{47}$, iniciou-se um movimento de repúdio ao ator reproduzindo os dizeres “rape jokes aren’t funny” [piadas de estupro não são engraçadas. O movimento deu origem a uma série de discussões, que rendem até os dias de hoje, sobre como a naturalização das piadas de estupro colaboram com a cultura do estupro. No Brasil, ainda em 2016, após o caso chocante da jovem que foi violentada por 33 homens no Rio de Janeiro ${ }^{48}$, ganharam frente nas mídias sociais os debates sobre a cultura do estupro, pondo em evidência comportamentos sutis ou explícitos que silenciam ou relativizam a violência sexual contra a mulher, pedindo que tais comportamentos deixem de ser vistos como naturais quando são, na verdade, culturais e violentos. "A culpa não é da vítima" virou slogan de uma campanha que chegou tarde, mas que tem ganhado cada vez mais força em sua tentativa de mudar uma realidade dolorosa para a mulher brasileira ${ }^{49}$.

Um outro motivo para mantermos a piada ultrajante é que ela não está ali para ser engraçada. Como já foi dito em nossa análise do conto no Capítulo 1, a personagem, desesperada para salvar o pai à beira da morte, conta todas as piadas que aprendeu com ele e que nunca parou para analisar e de fato compreender e, no fim da história, percebe que a graça das piadas era ele mesmo. As piadas são incômodas, sem graça, preconceituosas e o autor as escolheu por esse motivo: quando colocadas em um contexto narrativo de dor e sofrimento de um garoto perdendo o pai para o câncer, o leitor não está preparado para rir (como poderia ser o caso em um contexto informal em que ele ouvisse uma dessas piadas), ele está preparado para se solidarizar com o sentimento de perda da personagem, o que faz com que, ao ler uma piada como essa em uma situação tão trágica, ele se choque com o acúmulo de imagens fortes e perceba que ela não tem graça, que ela é absurda e não apenas naquele contexto, mas em qualquer um.

Seria o texto transgressivo pondo em prática seu papel de agente social inquietador, tentando fazer com que a reação do leitor seja de achar asqueroso e ultrajante, de se surpreender que não tenha antes percebido isso, que tenha rido com naturalidade de

\footnotetext{
${ }^{47}$ Um artigo da CNN, de Julie Burton e Michelle Bruns, a respeito do episódio na época que ele ocorreu e sua repercussão nas redes sociais, está disponível em: http://edition.cnn.com/2012/07/16/opinion/burtonbruns-tosh/. Acesso em março de 2017.

${ }_{48}$ Um pouco mais sobre o caso em: http://www.huffpostbrasil.com/2016/05/27/relato-vitima-estuprocoletivo_n_10162844.html?utm_hp_ref=mulheres. Acesso em março de 2017.

${ }^{49}$ Estima-se que, no Brasil, um caso de estupro seja notificado a cada 11 minutos. A afirmação foi feita com base nos dados mais recentes de pesquisa, de 2014. No entanto, prevê-se também que apenas um décimo dos casos seja notificado, portanto é possível que a realidade seja a de um caso de estupro por minuto no país. $89 \%$ das vítimas são do sexo feminino. Disponível em: http://www.bbc.com/portuguese/brasil-36401054. Acesso em março de 2017.
} 
piadas como essa e passe a questionar suas atitudes perante a zombaria de minorias políticas. Não é uma apologia a piadas de estupro, mas uma crítica a elas e da mesma forma que o original tenta mostrar isso, acreditamos que a tradução deva aproveitar a oportunidade de fazer o mesmo.

Em se tratando da tradução da piada em questão, queremos justificar uma decisão em particular: note que no original a moça pede uma Michelob das primeiras vezes que vai ao bar e, somente depois, pede uma Budweiser, enquanto na tradução ela pede, no início, Budweisers e, ao fim, uma Corona. Optamos por trocar os nomes de cerveja por acreditar que o efeito cômico (que a piada não tem, mas supondo que almejasse ter) se baseia no reconhecimento dos elementos dela pelo ouvinte. Como este poderia achar graça da piada sem saber o que é Michelob? E Michelob não é, de forma alguma, uma cerveja muito conhecida no Brasil, por não ter sido importada por nenhuma grande distribuidora nacional. Por outro lado, a Budweiser (popularmente conhecida como Bud), apesar de ser fabricada pela mesma cervejaria que a Michelob, já havia encontrado mercado no Brasil e, a partir de 2008, quando a cervejaria belgo-brasileira InBev comprou a Anheuser-Busch, pode ser vendida regularmente no país, tornando-se líder no mercado brasileiro de cervejas premium. Isso significa que será facilmente reconhecida pelo leitor brasileiro, assim como a cerveja Corona que, também tendo sido adquirida pela agora $\mathrm{AB}$ InBev, possui grande circulação e pode ser facilmente encontrada nos mercados nacionais, apesar de não ser tão popular quanto outras cervejas comercializadas aqui.

Nossa decisão de usar, respectivamente Budweiser e Corona no lugar de Michelob e Budweiser, foi fundamentada em uma pesquisa publicada no site huffpost.com ranqueando as 20 cervejas mais populares nos EUA ${ }^{50}$. Nossa intenção foi selecionar duas que fossem bastante populares lá e que também pudessem ser bem conhecidas aqui, caso da Budweiser, que ocupa a terceira posição, e da Corona Extra, que ocupa a quinta posição. A Michelob, por sua vez, encontra-se na oitava posição, portanto estamos confortáveis com nossa decisão de alterar as marcas na tradução.

e) E por fim:

\begin{tabular}{|c|c|}
\hline Texto original & Sugestão de tradução \\
\hline The kid tells about the Polack who's & O menino conta do Polonês que tava \\
carrying a rifle through the woods when he comes & andando pela floresta com uma espingarda e \\
\hline
\end{tabular}

\footnotetext{
${ }^{50}$ Disponível em: http://www.huffpostbrasil.com/entry/popular-beers-in-america-_n 6787494. Acesso em março de 2017.
} 
across a naked gal laying back on a bed of soft green moss with her legs spread, and this gal is a Real Looker, and she looks at the Polack and his gun and says, "What're you doing?" And the Polack says, "I'm hunting for game." And this Real Looker, she gives him a big wink and she says, "I'm game."

So-POW!- the Polack shoots her. encontra uma mina pelada deitada num monte macio de folhas verdes com as pernas abertas e ela é gata pra caralho e olha pro português com a arma e diz, "O que cê tá fazendo?" E o português diz, "Tô caçando comida". E a gostosa dá uma piscadinha e diz, "Pode vir me comer".

Daí - POW! - o português atira nela.

A piada acima baseia seu humor na premissa de que o sujeito sobre o qual ela narra é intelectualmente inferior, não compreende o que está acontecendo: ele está caçando, uma moça nua se oferece sexualmente a ele na floresta, ele acha que ela é a caça e a mata. A grande questão que envolve essa piada é a do humor étnico, que faz graça a partir de ataques a estereótipos de estrangeiros. Não se tratam de estrangeiros em geral, mas de nacionalidades especificas, dependendo do local de fala dessa piada: no Reino Unido as piadas são sobre irlandeses, na França, sobre os belgas, e na Noruega, sobre os suecos, por exemplo.

No caso de piadas com poloneses nos EUA, não se sabe ao certo a origem ou causa delas, mas há quem diga que tem a ver com o fato de muitos poloneses terem fugido da perseguição em seu país nos séculos XVIII e XIX e migrado para os EUA, onde passaram a prestar serviços domésticos como forma de se sustentarem e, logo, eram vistos como inferiores $^{51}$. Outra teoria é que o estereótipo surgiu e foi transformado em piada pelos alemães nazistas na Segunda Guerra Mundial, disseminadas nas propagandas políticas; os comunistas soviéticos perceberam que essa imagem lhes dava vantagem sobre os poloneses, pois, ao fazê-los parecer inferiores e sub-humanos, ninguém ligaria se seu país fosse ocupado pela União Soviética, e passaram a reproduzir essas piadas através de seus simpatizantes em Hollywood, que inseriram essa campanha contra os poloneses nos filmes e televisão norte-americanos ${ }^{52}$.

Independentemente de sua origem, no entanto, fato é que uma piada de polonês tem alcance certo nos receptores norte-americanos: ainda que não ache graça, quem ouve, compreende, e quando se inicia uma piada sobre ele, o ouvinte daqui já cria certa

\footnotetext{
${ }^{51}$ Fonte disponível em:

http://www.slate.com/articles/arts/culturebox/features/2014/the humor_code/polish_jokes_why_every_co untry has_one and why_only_americans_joke_about.html. Acesso em fevereiro de 2017.

${ }^{52}$ Fonte disponível em:

http://www.polamjournal.com/Library/Fighting_Defamation/The_Origin_of the_Polish_Joke/the_origin of the polish joke.html. Acesso em fevereiro de 2016.
} 
expectativa de que este fará algo não muito inteligente. No Brasil, a nacionalidade que causaria efeito similar é a do português e, sabendo que o efeito cômico está diretamente ligado àquela expectativa que implica um conhecimento prévio de que portugueses são tidos como burros, não traduzir "polonês" por "português" acarretaria perda do valor humorístico. Ainda assim, e apesar de darmos grande importância ao elemento do humor nesse texto específico, optamos por manter "polonês" na anedota, pelo cuidado de sermos, acima de tudo, consistentes em nosso projeto de tradução: propusemo-nos, desde o começo, a evidenciar a cor local, a cultura do outro, e não faria sentido um jovem norteamericano contar piadas de português. Sendo assim, mesmo que a tradução resultante acarrete em perda do referencial cômico para o leitor brasileiro, ele saberá que é do polonês que se faz graça nos Estados Unidos, e mesmo que não desperte nele o riso como no leitor do original, é possível que ainda a ache engraçada por todo o constrangimento da situação.

Além disso, há mais para a frente uma ambiguidade semântica em inglês com "game". O vocábulo "game" tem muitos significados e dentre eles, e mais relevantes para esse contexto, estão:

\section{"[mass noun] Wild mammals or birds hunted for sport or food"}

[[substantivo incontável] mamíferos ou pássaros selvagens caçados para fins de esporte ou alimentação]

\section{"ADJECTIVE Eager or willing to do something new or challenging" [ADJETIVO Ávido ou disposto a fazer algo novo ou desafiador" ${ }^{\text {"53 }}$}

Sendo assim, quando o polonês diz "I'm hunting for game", o que quer dizer é "Eu estou caçando animais", e quando a moça diz "I'm game”, ela quer dizer "Eu estou disposta a fazer algo desafiador com você” e, no caso, há uma conotação sexual envolvida por ela estar nua de pernas abertas no meio da floresta. Entretanto, por ser a mesma palavra, "game", ela mesma faz o trocadilho (como sugere a piscada de olho dela) e o polonês entende que ela é um animal a ser caçado e, portanto, atira nela. Toda a graça da piada está exatamente no fato de a palavra polissêmica ter causado confusão no polonês e, logo, algo do tipo precisaria acontecer em português também. A forma que encontramos de aproximar o efeito da tradução ao efeito do original foi a de substituir o

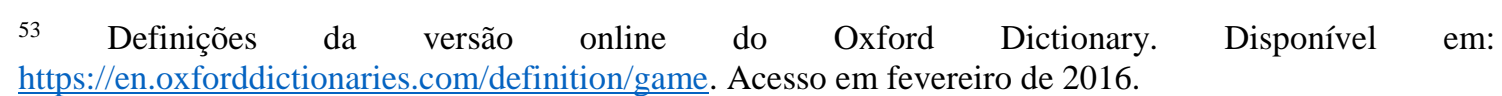


substantivo "game" por "comida" e o adjetivo "game" pelo verbo "comer". Isso porque “comer" também possui carga semântica sexual e, logo, também gera essa ambiguidade semântica que confundirá o português, mantendo-se o efeito cômico e o "script" da piada, se formos usar a terminologia de Schmitz (1996).

[2] Outro aspecto desse texto que nos preocupou um pouco foram as referências a personalidades cômicas famosas nos Estados Unidos. São citados Groucho Marx (e, mais adiante no texto, os Irmãos Marx), Uncle Milty, Edward Bergen e seu boneco Charlie McCarthy, Robin Williams, Abbott, Costello, Laurel, Hardy e Charles Chaplin. Algumas delas não representavam grandes problemas por terem adquirido fama internacional: Charles Chaplin, em especial, despensa apresentações, sendo conhecido principalmente por O garoto (1921), Luzes da cidade (1931), Tempos modernos (1936) e O grande ditador (1940); e Robin Williams também é bastante popular por conta de grandes filmes hollywoodianos, como Sociedade dos poetas mortos (1989), a voz do Gênio em Aladdin (1992), Gênio indomável (1997, que lhe rendeu o Oscar de melhor ator), Patch Adams - o amor é contagioso (1998), O homem bicentenário (1999), A.I. Inteligência artificial (2000), entre muitos outros, que tiveram grande alcance e boa aceitação do público brasileiro.

Apesar de um pouco menos conhecidos que Chaplin e Williams, também podemos partir do princípio de que os Irmãos Marx, entre eles Groucho Marx, a dupla Abbott e Costelo e a dupla Laurel e Hardy, no Brasil chamados de o Gordo e o Magro, são referências acessíveis para quem possui um conhecimento básico sobre cinema cômico e humor pastelão ou, mesmo para quem não tem esse conhecimento, talvez já tenha ouvido falar alguma vez nesses atores. Os mais complicados, no caso, seriam Uncle Milty, personagem do comediante norte-americano Milton Berle, que viveu ente 1908 e 2002 e é considerado a primeira grande estrela da TV americana, e Edgar Bergen, comediante que viveu entre 1903 e 1978 e foi mais conhecido pelo seu trabalho como ventríloquo, principalmente com o boneco Charlie McCarthy, com quem tinha seu próprio programa de TV.

Nossa estratégia para lidar com esses nomes na tradução foi a de mantê-los, pois é compreensível pelo contexto que se tratam de comediantes. Quando julgamos não ter ficado tão claro, fizemos acréscimos no texto para clarificar sem que se fizesse necessária uma nota de tradutor: 


\begin{tabular}{|c|c|}
\hline \multicolumn{1}{|c|}{ Texto original } & \multicolumn{1}{c|}{ Sugestão de tradução } \\
\hline $\begin{array}{l}\text { Understand me: My old man is no Uncle } \\
\text { Milty. He's no Edgar Bergen. }\end{array}$ & $\begin{array}{l}\text { Olha só: meu coroa não é nenhum Uncle } \\
\text { Milty. Nenhum Edgar Bergen ou qualquer um } \\
\text { desses comediantes. }\end{array}$ \\
\hline $\begin{array}{l}\text { BcCarthy, the whole time I was growing up, he } \\
\text { used to ask me, "Knock-knock?" }\end{array}$ & $\begin{array}{l}\text { Na época que eu era o bonequinho dele, } \\
\text { feito o Charli McCarthy, o tempo todo enquanto } \\
\text { eu crescia, ele me perguntava, "Toc-toc?" }\end{array}$ \\
\hline
\end{tabular}

Pode ser que não seja a melhor saída, mas nos pareceu a melhor forma de nos manter fiéis ao projeto de tradução que propomos, ao invés de buscar uma fidelidade forçada e inexistente (pois qualquer tradução "trai" o original, mesmo sem querer) ao texto de partida.

[3] Um último comentário que faremos sobre a tradução desse conto se refere às palavras grafadas incorretamente. Acreditamos que elas estejam ali para indicar a ignorância e infantilidade da personagem, para mostrar que ele é um jovem adulto, abandonado pela mãe e aparentemente negligenciado pelo pai, que tem uma vaga noção do que está acontecendo ao seu redor, mas não sabe muito sobre a vida. Ele frequentou a escola (ou talvez tenha apenas assistido televisão e lido revistas) o suficiente para saber da existência de Emily Dickinson e Jean-Paul Sartre, e saber que ambos abordavam temas como a morte em suas obras, mas não tem familiaridade o bastante com eles para lembrar seus nomes corretamente (ele diz Emily Dickerson e Jean-Paul Stuart).

Os erros das palavras e dos nomes das personalidades, porém, parecem pouco naturais, pois são cometidos em momentos, a princípio, aleatórios no texto. Acreditamos que o autor possa ter feito isso no intuito de chamar ainda mais atenção para os deslizes quando eles ocorrem, de forma a representar alegoricamente o nível intelectual da personagem. A tabela a seguir mostra as palavras alteradas e como ficou nossa tradução:

\begin{tabular}{|l|l|}
\hline \multicolumn{1}{|c|}{ Texto original } & \multicolumn{1}{c|}{ Texto traduzido } \\
\hline multiple-cation tables & tabuada de multiplacanção \\
\hline Prostrate câncer & Câncer de próstada \\
\hline End-orphans & Em-dores-finas \\
\hline Oxy-generated & Sangue oxi-generado \\
\hline
\end{tabular}

A tradução de "Knock-knock" foi desafiadora, mas acreditamos que, em especial quando lida em voz alta, ela reproduz de forma interessante os efeitos do conto original. 


\subsection{How Monkey got married, bought a house and found happiness in Orlando $^{54}$}

Como já foi dito no Capítulo 1 (sessão 1.3.2.2), esse conto é uma fábula contemporânea que acompanha um recorte da vida de Macaca, jovem recém-formada em Comunicação que, trabalhando como promotora de produtos teste para uma empresa do ramo de alimentos, recebe o desafio de impulsionar as vendas de um queijo. $\mathrm{O}$ texto, bem como os outros dois que completam a trilogia de fábulas na coletânea Make something up (2015), "Why Coyote never had Money for parking" e "Why Aadvark never landed on the moon", é escrito de forma bem diferente das outras histórias da obra: sua narrativa em terceira pessoa segue mais à risca a norma culta da escrita em língua inglesa, sua linguagem é simples e didática, numa tentativa de reproduzir o tom das versões escritas de fábulas clássicas, e soa condescendente, como se seu objetivo fosse mesmo apresentar uma lição de moral.

Por esse motivo, adotamos uma estratégia de tradução diferente com esse texto. Aqui o português obedece a norma padrão (não há espaço para oralidade na narrativa, por exemplo) e buscamos aproximar sua linguagem àquela das fábulas já traduzidas no Brasil e também criadas aqui, como as fábulas de Monteiro Lobato, que costumam ser simples e diretas, utilizam frases curtas e trazem muitos diálogos. Apresentaremos, a seguir, alguns exemplos de trechos traduzidos para ilustrar a estratégia escolhida e algumas soluções que encontramos para dificuldades que se apresentaram ao longo da tradução.

[1] Assim como acontece nas fábulas tradicionais, a fábula de Chuck Palahniuk traz muitos diálogos, durante os quais se desenvolve a ação principal do texto. Foi, então, para manter esse grau de semelhança com as fábulas escritas em português e para dar ênfase aos diálogos, que optamos por utilizar travessões nessa tradução, ao invés das aspas que deixamos nos outros contos, como mostra o exemplo a seguir:

\begin{tabular}{|c|r|}
\hline \multicolumn{1}{|c|}{ Texto original } & Sugestão de tradução \\
\hline That night in her Orlando motel room, & Aquela noite em seu quarto de hotel em \\
Monkey telephoned Hamster and said, "I think my & $\begin{array}{c}\text { Orlando, a Macaca ligou para o Hamster e disse: } \\
\text { cheese is poison." }\end{array}$ \\
And over the phone Hamster replied, & E, pelo telefone, o Hamster respondeu: - \\
"Relax, your cheese is fine." & Relaxe, seu queijo está bom. \\
\hline
\end{tabular}

\footnotetext{
${ }^{54}$ Para a tradução e original completos, vide Anexo B (p.138).
} 


\begin{tabular}{|l|r|}
\hline $\begin{array}{r}\text { "It doesn't smell fine," Monkey insisted. } \\
\text { "We're counting on you," Hamster said. }\end{array}$ & - Ele não cheira bem, a Macaca insistiu. \\
"If anybody can open a market niche for this & Hamster. — Se existe alguém que pode arrumar \\
cheese, you can." & um lugar no mercado para esse queijo, é você. \\
\hline
\end{tabular}

De um modo geral, a pontuação da tradução obedece mais às regras do português do que ao apresentado no original. Isso porque acreditamos que fazer esse texto soar mais natural em português, com menos marcas estrangeirizadoras ou elementos que causem certo estranhamento no leitor, iria mais de encontro ao que acreditamos ser o objetivo desse conto em particular. Dessa forma, a tradução se aproxima mais de fábulas que um leitor do português tenha lido e faz com que ele reconheça o texto como fábula.

[2] Outro elemento que caracteriza um texto imediatamente como fábula é o uso antropomórfico dos animais como personagens, como já foi dito no capítulo 2 (tópico 2.3.2). Diferentemente das fábulas tradicionais, no entanto, que apresentam um número bastante reduzido de personagens (normalmente entre um ou dois, apenas), a fábula traduzida aqui não se limita a isso e conta com vários animais representando pessoas. Os nomes dos animais funcionam como nomes próprios e, a partir deles, pode-se ter uma ideia da personalidade dessas personagens por associarmos aos traços já conhecidos desses animais. Seguindo a classificação de Theo Hermans de substantivos convencionais ou carregados de significado, reconhecemos os nomes de animais como carregados e, apesar de no texto representarem nomes próprios que em outra circunstância poderia permanecer em inglês, sua tradução se justifica exatamente pela carga de significado que eles têm, em especial dentro de uma fábula.

Em geral, nossa estratégia foi traduzi-los diretamente, pois, mesmo sabendo que alguns desses animais não existem no Brasil, o que dificultaria essa associação imediata, os tradutores das fábulas tradicionais não parecem ter tido essa preocupação, tampouco, fato evidenciado em fábulas clássicas como "A raposa e as uvas" e "A lebre e a tartaruga", ambas contendo animais que não fazem parte da fauna tupiniquim. Além disso, como já vimos com Portella, não é "necessário que tais associações sejam universalmente conhecidas" (PORTELLA, 1983, p. 136), pois o que determina o conjunto de características que o animal representa é o contexto da obra, portanto, acreditamos que traduzir diretamente esses nomes próprios é funcional para o conto e uma forma, também, de manter uma conexão com o contexto cultural de partida. 
Seguem alguns exemplos de como se deu essa tradução:

\begin{tabular}{|l|l|}
\hline \multicolumn{1}{|c|}{ Texto original } & \multicolumn{1}{|c|}{ Sugestão de tradução } \\
\hline [...]. Blessed was Monkey with charm, and when & {$[\ldots]$. Macaca fora abençoada com charme e quando } \\
she smiled at Stag or Panther or Eagle, they & sorria para o Cervo ou o Pantera ou o Águia, eles \\
smiled in return and sought to buy whatever & sorriam de volta e corriam para comprar o que quer \\
product Monkey was shilling. & que Macaca estivesse promovendo. \\
\hline
\end{tabular}

$$
\begin{gathered}
\text { Stag } \rightarrow \text { Cervo } \\
\text { Panther } \rightarrow \text { Pantera } \\
\text { Eagle } \rightarrow \text { Águia }
\end{gathered}
$$

O que vale notar nesse trecho, é que se trata de uma referência sexista de como o corpo da mulher é usado de plataforma de marketing para promover produtos, de como a própria Macaca usa seu charme para seduzir e convencer clientes, em geral homens, a comprar aquilo que ela está vendendo. Os três animais que o autor selecionou para esse trecho são criaturas imponentes, de porte ameaçador, e entendemos que seriam personagens masculinas, portanto, mesmo "pantera" e "águia" sendo substantivos femininos, utilizamos o artigo definido masculino.

[3] Em se tratando de artigos, também vale comentar a decisão que tomamos ao longo do conto. Sabe-se que o uso do artigo definido na frente de nomes próprios é facultativo, mas, como em alguns trechos julgamos sua presença importante para a fluidez e maior clareza do texto, optamos por padronizar e colocar o artigo definido nos nomes de todos os animais, em todas as ocorrências.

\begin{tabular}{|c|r|}
\hline Texto original & Sugestão de tradução \\
\hline She sold cigarettes to Badger, who did & Ela vendia cigarros para o Texugo, que \\
not smoke. And Monkey sold beef jerky to Ram, & não fumava. E a Macaca vendia bifes de charque \\
who did not eat meat. So clever was Monkey that & para o Carneiro, que não comia carne. Tão \\
she sold hand lotion to Snake, who had no hands! & $\begin{array}{l}\text { esperta era a Macaca que vendeu creme de mão } \\
\text { para a Cobra, que não tinha mãos! }\end{array}$ \\
\hline
\end{tabular}

Note que aqui, se omitíssemos o artigo definido o resultado seria "cigarros para Texugo", "bifes para Carneiro" e "creme para Cobra", de forma genérica, havendo a possibilidade de interpretar de interpretar, por exemplo, que era um creme de mão para 
cobras, em geral, não um creme vendido para a cobra. Por isso o uso do artigo em todo o texto pareceu uma opção melhor do que não usá-lo em momento algum.

Uma vez que o artigo definido foi empregado à frente de cada nome próprio, tomamos a seguinte decisão no começo do texto:

\begin{tabular}{|l|l|}
\hline \multicolumn{1}{|c|}{ Texto original } & \multicolumn{1}{c|}{ Sugestão de tradução } \\
\hline Many years ago, in a world before & Muitos anos atrás, em um mundo antes da \\
disillusionment, Monkey walked through the & desilusão, uma Macaca andava pela floresta, sua \\
forest, her mouth overflowing with pride. After & boca transbordando de orgulho. Após muito \\
much effort and sacrifice, she had finished her & esforço e sacrifício, ela tinha terminado seu longo \\
lengthy schooling. To Raven, Monkey bragged, & período de estudos. Para o Corvo, a Macaca se \\
"Look at me! I have an undergraduate degree in & gabou: — Olhe para mim! Tenho um diploma de \\
Communications!" & graduação em Comunicação! \\
\hline
\end{tabular}

Ao ler uma série de fábulas em português, pudemos notar que uma grande maioria utiliza o artigo indefinido na primeira vez que se refere ao animal sobre o qual será a história, como forma de generalizar a personagem: não se trata de um animal específico, poderia ser qualquer leão, qualquer macaco ou qualquer formiga. No conto de Palahniuk, porém, não é isso de acontece; é uma fábula, mas as personagens são individualizadas, apresentam certa profundidade, angústias, medos e expectativas. $\mathrm{O}$ autor mostra isso ao utilizar os nomes dos animais sempre em letras maiúsculas, como nomes próprios. Uma vez que já tínhamos escolhido usar o artigo definido em todas as ocorrências desses nomes, no entanto, decidimos utilizar o artigo indefinido antes da primeira vez que "Macaca" aparece, como forma de aproximar ainda mais a fábula traduzida da fábula clássica para, ao longo dela, aumentar o contraste entre as duas ao mostrar todo o desenvolvimento da ação e das personagens, que vai muito além daquele das fábulas tradicionais.

[4] Outra decisão que tomamos e vale comentar, foi a de explicar dois indicadores culturais em meio ao texto:

a)

\begin{tabular}{|c|c|}
\hline Texto original & Sugestão de tradução \\
\hline Hamster let slip that Monkey's archrival, & O Hamster deixou vazar que o arqui- \\
Coyote, was launching the same cheese in & $\begin{array}{c}\text { inimigo da Macaca, o Coiote, estava promovendo } \\
\text { o mesmo queijo na região de Raleigh-Durham e }\end{array}$ \\
\hline
\end{tabular}




\begin{tabular}{|l|l|l|}
\hline $\begin{array}{l}\text { Raleigh-Durham and wasn't reporting any } \\
\text { consumer resistance. }\end{array}$ & $\begin{array}{l}\text { não havia relatado qualquer resistência por parte } \\
\text { dos consumidores. }\end{array}$ \\
\hline
\end{tabular}

b)

\begin{tabular}{|c|c|}
\hline \multicolumn{1}{|c|}{ Texto original } & \multicolumn{1}{|c|}{ Sugestão de tradução } \\
\hline \multicolumn{1}{|c|}{ Instead, she sat in bed, hearing the } & Ao invés disso, sentou-se na cama, \\
grunting and rutting through the motel wall and & ouvindo os gemidos e fricções através da parede de \\
pretending to read The Wapshot Chronicle. & $\begin{array}{l}\text { hotel e fingindo ler o clássico A crônica dos } \\
\text { Wapshot, de John Cheever. }\end{array}$ \\
\hline
\end{tabular}

No primeiro caso, Raleigh e Durham são duas das cidades que compõem o famoso Research Triangle [Triângulo de Pesquisa], na Carolina do Norte, juntamente com Chapel Hill, e abrigam três grandes universidades norte-americanas (North Carolina State University, Duke University e The University of North Carolina at Chapel Hill), e inúmeras empresas de pesquisa em tecnologia, que foram atraídas para a região na década de 1950 devido às instalações e laboratórios de pesquisa das universidades. Além disso, Raleigh e Durham são as metrópoles que, juntamente com a micrópole Chapel Hill e os condados de Dunn, Henderson, Sanford e Oxford, formam a Área de Estatística Combinada $^{55}$ de Raleigh-Durham-Chapel Hill, mais comumente chamada de RaleighDurham. Para que o leitor saiba que Raleigh e Durham são duas cidades diferentes, embora conectadas pelo hífen, sem que haja a necessidade de uma nota do tradutor ou que interrompa sua leitura para pesquisar, achamos pertinente acrescentar "a região" a Raleigh-Durham, um acréscimo simples, que pode deixar a leitura mais confortável.

No segundo caso, The Wapshot chronicle foi o primeiro romance escrito pelo autor norte-americano John Cheevers, publicado em 1957 e vencedor do prêmio National Book Award for Fiction de 1958. Parcialmente baseado na adolescência de Cheever em New England, o romance acompanha os destinos da excêntrica família Wapshot, de St. Botolphs, uma tradicional vila de pesca de Massachusetts. Aqui estão as histórias do Capitão Leander Wapshot, marinheiro e suicida em potencial, de seus filhos, Moses e Coverly (personagem que, presume-se, representaria o autor, já que, assim como ele, Coverly teve experiências bissexuais) e da avarenta prima Honora, guardiã da fortuna da família. Não fica claro, considerando a premissa da obra em questão, o motivo de Palahniuk tê-la escolhido como leitura da personagem, mas podemos supor que isso

\footnotetext{
55 Áreas de Estatística Combinada (Combined Statistic Area ou CSA, na sigla em inglês) são áreas compostas por regiões metropolitanas e micropolitanas adjacentes que compartilham índices e padrões econômicos e sociais entre si e, por isso, são consideradas em conjunto quando de pesquisas estatísticas.
} 
queira dizer algo sobre Macaca, pois a) trata-se de um cânone da literatura norteamericana e a preferência dela por esse título pode defini-la como culta e inteligente, o que torna ainda mais trágico e degradante o fato de ter que objetificar seu próprio corpo para promover produtos; e b) na obra, as personagens femininas são fortes, roubam a cena e guiam os rumos que a vida de Leander, Moses e Coverly tomam, o que pode indicar um desejo de Macaca de se empoderar e posicionar enquanto mulher em um universo predominantemente masculino.

Cheever é mais famoso por seus contos, pelos quais o comparam com Anton Tchekhov, do que pelos romances, mas mesmo seus romances sempre tiveram boa recepção entre os leitores e críticos norte-americanos. Em 1979, o autor foi o vencedor do Prêmio Pulitzer de Ficção pela coletânea de contos The stories of John Cheever (1978), que também lhe rendeu o prêmio National Book Critics Circle Awards e reconhecimento internacional. Oito de seus livros já contam com traduções no Brasil e A crônica dos Wapshot já foi, inclusive, traduzida para o português três vezes: em 1968, pela Edinova, em 2002, pela editora Arx, e em 2012, pela Companhia das Letras ${ }^{56}$. Ainda assim, Cheever permanece pouco conhecido entre os brasileiros, ainda mais entre o público alvo da obra de Chuck Palahniuk, e, por esse motivo, consideramos que esclarecer que $A$ crônica dos Wapshot se trata de um clássico de John Cheever, agregaria valor à leitura.

De um modo geral, a fábula foi, dentre os contos, o que menos apresentou desafios de tradução e acreditamos ter conseguido transpô-la para o português de forma satisfatória.

\subsection{Zombies $^{57}$}

A narrativa do conto é um relato informal de um adolescente, acelerado, ritmado e repleto de analogias e metáforas que são parte da realidade em que ele vive. Diferente dos outros dois contos que apresentam marcas de oralidade, nessa o jovem se mostra inteligente, antenado e lúcido, em pleno controle de suas faculdades mentais, e isso transparece em seu discurso. Apesar de usar tantas gírias, contrações e abreviações quanto os outros narradores e soar como soaria um adolescente contando uma história, ele também traz referências muito mais ricas, sacadas bem pensadas e um tom mais irônico, como mostram os trechos abaixo:

\footnotetext{
${ }^{56}$ Não tivemos acesso às duas primeiras traduções para descobrir quem foram os tradutores, mas no caso da edição da Companhia das Letras, foi Alexandre Barbosa de Souza.

${ }^{57}$ Para a tradução e original completos, vide Anexo C (p.154).
} 
We're basically big animals, evolved to break open shells and eat raw oysters, but now we're expected to keep track of all 300 Kardashian sisters and 800 Baldwin brothers. Seriously, at the rate they reproduce the Kardashians and the Baldwins are going to wipe out all other species of humans. The rest of us, you and me, we're just evolutionary dead ends waiting to wink out. (PALAHNIUK, 2015, p. 29).

\section{No offense to Jesus, but the meek won't inherit the earth. To judge from} reality TV the loudmouths will get their hands on everything. And I say, let them. The

Kardashians and the Baldwins are like some invasive species. Like kudzu or zebra mussels. Let them battle over the control of the crappy real world. (PALAHNIUK,

$$
\text { 2015, p. 32). }
$$

O conto é narrado em primeira pessoa e o narrador reconhece a presença do interlocutor, dirigindo-se diretamente a ele em alguns momentos, o que certamente nos aproxima da narrativa enquanto leitores. Parece que estamos sentados do seu lado enquanto ele conta a história, revivendo com ele aquele momento a ponto de, ao fim, ser possível nos emocionarmos com a corrente que se forma para salvar a vida de Trevor e que conecta todas essas pessoas.

Em termos de tradução, os desafios com a linguagem e aspectos culturais se repetem, porém as referências que temos nesse texto, talvez por se tratar de um adolescente, que faz menções a uma cultura popular muito mais recente e imediata, de mais fácil acesso para o leitor da tradução, foram menos difíceis de lidar. A seguir, trazemos alguns exemplos desses casos:

[1] O primeiro trecho apresenta duas situações interessantes:

\begin{tabular}{|r|r|}
\hline \multicolumn{1}{|c|}{ Texto original } & Sugestão de tradução \\
\hline In Miss Chen's English class, we learned & Na aula de inglês da Sta. Chen, a gente \\
"To be or not to be," but there's a big gray area in & aprendeu sobre o "ser ou não ser", mas existem \\
between. Maybe in Shakespeare times people only & vários tons de cinza entre uma coisa e outra. Vai \\
had two options. Griffin Wilson, he knew the & ver nos tempos do Shakespeare as pessoas só \\
SATs were just the gateway to a big lifetime of & tivessem duas opções. O Griffin Wilson, ele sabia \\
bullshit. To getting married and going to college. & que as provas do SAT eram só a porta de entrada \\
To paying taxes and trying to raise a kid who's not & pruma grande vida de merda. Pra se casar e ir pra \\
a school shooter. And Griffin Wilson knew drugs & a faculdade. Pra pagar impostos e tentar criar filhos \\
& que não acabem entrando numa escola metendo \\
\hline
\end{tabular}


are only a patch. After drugs, you're always going to need more drugs. bala em geral. E o Griffin Wilson sabia que drogas são que nem tapar o sol com a peneira. Depois das drogas, cê sempre precisa de mais drogas. Depois das drogas, você sempre precisa de mais drogas.

No primeiro, temos "SAT", uma sigla para Scholastic Aptitude Test [teste de aptidão escolar, em tradução livre], um exame admissional utilizado pela maior parte das universidades dos EUA como plataforma de ingresso em programas de graduação. Por ser aplicado a nível nacional e aceito pelas universidades em geral, é possível comparálo ao ENEM. Para fins de tradução, entretanto, substituir uma coisa pela outra foge muito do que pretendemos como estratégia de tradução, portanto não foi considerado como opção. Levando em conta que essa prova é exaustivamente mencionada em outros livros, séries, filmes e mídias diversas a que temos acesso, optamos por manter a sigla (sem escrever por extenso, pois sendo um relato da personagem, ela usaria apenas a sigla) e acrescentar "as provas", para que o leitor entenda que se trata de um tipo de exame sem precisar parar e pesquisar, caso não queira.

No segundo, temos uma referência aos recorrentes episódios de jovens entrando nas escolas dos EUA e atirando indiscriminadamente nas pessoas. Esse tipo de incidente é assustadoramente comum no país. Uma pesquisa do grupo Everytown for Gun Safety Support Fund [Fundo de Apoio Everytown para Segurança relacionada à Armas de Fogo, em tradução livre $]^{58}$, publicada em 3 de outubro de 2015, aponta um total de 188 ocorrências de tiroteios em escolas de 2013 até então, ou seja, em menos de três anos.

No caso da tradução, "school shooter" é uma expressão que aciona muito rapidamente as referências a tais atentados, mas não estamos seguros de que "atirador de escolas", sozinho, tem o mesmo efeito. Por esse motivo, decidimos aumentar a frase, esclarecendo-a, buscando manter o tom informal e o resultado foi: "tentar criar filhos que não acabem entrando numa escola metendo bala em geral".

[2] E seguida, temos o exemplo de uma referência a um programa de TV que decidimos alterar:

\begin{tabular}{|c|c|}
\hline \multicolumn{1}{|c|}{ Texto original } & \multicolumn{1}{c|}{ Sugestão de tradução } \\
\hline $\begin{array}{l}\text { [...] The rest of us are fighting tooth and nail for } \\
\text { whatever garbage career we can get, while Griffin }\end{array}$ & $\begin{array}{l}{[\ldots] \text { O resto de nós tá lutando com unhas e dentes }} \\
\text { pra conseguir qualquer carreira lixo que seja, }\end{array}$ \\
\hline
\end{tabular}

\footnotetext{
${ }^{58}$ Disponível em: https://everytownresearch.org/school-shootings/. Acesso em junho de 2016.
} 
Wilson is going to be thrilled with penny candy and reruns of Fraggle Rock for the rest of his life. enquanto o Griffin Wilson vai ficar felizão com docinhos baratos e reprises dos Muppets pro resto da vida.

Tal alteração se justifica pelo seguinte: Fraggle rock, no Brasil Fraggle rock: a rocha encantada, foi uma das várias séries de TV estreladas pelos muppets, criaturas diversas que podem ser animais, humanoides, monstros, ETs ou seres de outra natureza. Ela foi ao ar nos EUA entre 1983 e 1987, e foi vendida e dublada para mais de 95 países, após o sucesso avassalador do Muppet show, programa que havia conferido fama internacional aos personagens quando exibida, entre os anos de 1976 e 1981. Entretanto, Fraggle rock, hoje em dia, não é tão conhecida no Brasil, pois, ao contrário dos Estados Unidos, onde o programa tem sido periodicamente reprisado pela $\mathrm{HBO}$, aqui ele não vai ao ar há anos, especialmente na TV aberta, que daria mais acesso ao público. Não há no nome, Fraggle rock: a rocha encantada, indicação de que se trate desse universo fictício e dessas personagens, que é o que conta na referência do autor, e é por isso que optamos por utilizar o nome genérico da franquia, Os Muppets, que, não há a menor dúvida, será reconhecido pelos leitores brasileiros.

[3] E, por fim:

\begin{tabular}{|c|c|}
\hline Texto original & Sugestão de tradução \\
\hline To have no worries, no regrets-it's pretty & Não ter preocupações nem \\
appealing. So many of the cool kids at my school & arrependimentos - é bem atraente. Tanta gente \\
have elected to self-fry that, anymore, only the & descolada da minha escola já decidiu se autofritar \\
losers are left. The losers and the naturally & que agora só sobraram os zé ruelas. Os zé ruelas e \\
occurring pinheads. The situation is so dire that I'm & os que já nasceram retardados. A situação é tão feia \\
a shoo-in to be valedictorian. That's how come my & que com certeza eu vou ser o orador da turma. É \\
uncle Henry is shipping me off. He thinks that by & por causa disso que meu tio Henry tá me mandando \\
relocating me to Twin Falls he can postpone the & embora. Ele acha que me transferindo pra Twin \\
inevitable. & Falls, em Idaho, pode adiar o inevitável. \\
\hline
\end{tabular}

Dos termos que destacamos no trecho, temos, primeiramente, o vocábulo "losers". Ele não é empregado nesse contexto apenas para qualificar pessoas que perdem em jogos, por exemplo, mas que perdem na vida. É uma expressão degradante que quer dizer que o "loser" é incompetente e fadado ao fracasso. Traduzir para "perdedor" não seria suficiente, pois não transmite essa carga tão pejorativa, por isso optamos por uma expressão em português que dissesse algo semelhante, logo, "zé ruela". 
Depois, a personagem conta que seu tio o está mandando embora para Twin Falls, a maior cidade do condado de Twin Falls, localizado no estado do Idaho. É possível que os leitores conheçam a cidade ou já tenham ouvido falar, não poderíamos supor nem que sim nem que não, mas, como não se trata de uma cidade corriqueiramente citada em séries, filmes, livros ou outras fontes a que os leitores brasileiros poderiam ter fácil acesso, optamos por clarificar um pouco, acrescentando o estado à cidade para ajudar o leitor a se localizar.

\subsection{Loser $^{59}$}

Chegamos, enfim, ao último conto de nosso corpus, "Loser", que é interessante e rico em desafios de tradução. Em primeiro lugar, dentre os quatro textos traduzidos durante a pesquisa, ele é o que mais contém marcadores culturais, incluindo, mas não limitado a, programas e apresentadores de TV norte-americanos, a marcas, lojas, elementos da vida universitária norte-americana etc, e a maioria dos quais não fazem parte da cultura de massa globalizada à qual, mesmo enquanto estrangeiros, teríamos acesso, sendo, portanto, elementos de difícil assimilação para os leitores.

Em segundo lugar, assim como "Knock-kock", trata-se de um texto de narrativa bastante oralizada e, ainda por cima, com a voz de um jovem adulto sob efeito de LSD. Seu discurso é informal e conversacional, repleto de interjeições, gírias e coloquialismos, mais uma vez correspondendo aos recursos listados por Preti (2004), como podemos ver no exemplo abaixo:

“The old game show host, he's looking at you like maybe he's never, ever seen a telephone before. He goes, "And what do you bid?"

\section{And you go, "Eight bucks?"}

From the look on the old grandma's face, it's like maybe they should call some paramedics for her heart attack.” (PALAHNIUK, 2015, p. 43).

Para reproduzir não apenas a fala de um adolescente, mas a fala de um adolescente drogado, Palahniuk se vale de recursos como a repetição do sujeito com "the old host, he" (que, diga-se de passagem, acontece com frequência nos contos apresentados), uso da versão abreviada de palavras (grandmother's = grandma'a) e de contrações (he is =

\footnotetext{
${ }^{59}$ Para a tradução e original completos, vide Anexo D (p. 172).
} 
he's), e também uso de gírias ou expressões particulares do discurso oral ("he goes", ao invés de "he says", e "bucks", ao invés de "dollars").

Aproveitamos o exemplo para comentar, também, os vários padrões de repetição que o autor emprega ao longo do conto. É comum que isso ocorra nos textos de Palahniuk: em geral, todo romance seu tem uma frase de efeito, slogan ou algo do gênero que é repetido periodicamente, como o refrão de uma música, que auxilia na marcação do ritmo da narrativa (um leitor atento consegue perceber esse padrão e encontrar, observando as repetições, ordem no caos que costumam ser as obras do autor).

Em Fight club (2005, no caso da nossa edição, mas originalmente publicado em 1996), por exemplo, no capítulo 3 a personagem viaja a trabalho para várias cidades e, ao narrar como se sente convivendo com a insônia, ele repete "You wake up at Air Harbor International. [...] You wake up at O'Hare. You wake up at La Guardia. You wake up at Logan. [...]You wake up at Dulles. [...] You wake up at Love Field”. (PALAHNIUK, 2005, p. 25-6), no mínimo vinte vezes, e isso cria no leitor a sensação angustiante de cochilar sem pegar no sono e abrir os olhos sem nunca estar mesmo acordado. Mas a frente a personagem diz ter lido uma coluna na revista Reader's digest em que, a cada edição, um órgão do corpo humano narra sua história na primeira pessoa: "I'm Jane's Uterus. I am Joe's Prostate" (2005, p. 58), e, reconhecendo-se ("Hearing this, I am totally Joe's Gallbladder"), ele passa a usar essa frase para expressar como se sente em todo o restante do livro:

$$
\begin{aligned}
& \text { “I'm Joe's Raging Bile Duct” (2005, p. 59). } \\
& \text { “I'm Joe's Clenching Bowels" (2005, p. 62). } \\
& \text { “I'm Joe's Blood-Boiling Rage” (2005, p. 96) } \\
& \text { “I'm Joe's Cold Sweat” (2005, p. 184). }
\end{aligned}
$$

No conto em questão, alguns dos padrões de repetição que conseguimos identificar reforçam a ideia de que a personagem é jovem e alienado, como mostram, respectivamente, a repetição da gíria "like" incontáveis vezes e a forma pela qual ele se refere às pessoas como "algo de alguém": "something you might maybe get excited to win if you were, like, somebody's wife" (2015, p. 40), “There's always somebody's old grandma wearing a sweatshirt" (2015, p. 41) e "Her fashion model waist, about as big around as somebody's neck" (2015, p. 42), são apenas alguns exemplos. Cabe aqui comentar que traduzimos o "somebodies" do texto como "algos de alguém", apesar de correr o risco de soar forçado em português e nada parecido com algo que um adolescente 
diria, exatamente para manter essa aproximação repetitiva com o texto de partida, destacando esse traço da personalidade do narrador. Segue um exemplo:

\begin{tabular}{|r|r|}
\hline \multicolumn{1}{|c|}{ Texto original } & \multicolumn{1}{c|}{ Sugestão de tradução } \\
\hline It's the Hello Kitty, the popular kind, not & É a Hello Kitty, o tipo mais comum, não \\
the strawberry flavor or the chocolate flavor & a sabor morango ou sabor chocolate que o irmão \\
somebody's brother cooks at night in the General & de alguém cozinha a noite no prédio de Ciências \\
Sciences building where he works as a janitor. & Gerais que ele trabalha de zelador. \\
\hline
\end{tabular}

Além disso, há repetições de caracterizam sua fala alterada pelo alucinógeno e auxiliam na construção de uma imagem angustiante da "bad trip" do garoto. São elas a repetição de "million-billion" e "million-zillion" e todas as menções de luzes piscando, ligando e desligando:

Those Las Vegas lights, flashing, outlining everything onstage. [...] all the lights everywhere flashing on and off, only fast, blink, blink, blink, except faster than a human mouth could say. [...] Those flashing Las Vegas kind of lights blinking all around. [...] and he music starts, loud, and the light flash on and off. [...] Those Las Vegas lights blinking on and off, on and off. On and off. (PALAHNIUK, 2015, p. 41-48).

Outro aspecto da narrativa desse conto que precisamos comentar rapidamente é o fato de ele ser escrito em segunda pessoa. É uma estratégia inteligente do autor para fazer com que o leitor se torne personagem passivo, faça parte daquela história e sinta o que sentiu o narrador. Isso gera empatia por parte do leitor com a personagem, pois, se aquilo está acontecendo com você, você consegue se colocar no lugar do outro e, ao invés de julgar, compreende o porquê de determinadas ações. Além disso, por estar vivendo junto com a personagem tudo o que acontece na história, o leitor não questiona a veracidade do que está sendo narrado, o que faz da narrativa em segunda pessoa uma forma de convencer o leitor de que aquilo que ele lê é uma verdade (não verdade como se não fosse ficção, continua o sendo, mas verdade pela personagem ter mesmo vivido aquilo).

Seguem agora alguns exemplos de trechos que apresentam referências muito específicas da cultura norte-americana e os resultados de como contornamos tais obstáculos.

[1] Logo no primeiro parágrafo já nos deparamos com o seguinte:

\begin{tabular}{|r|r|}
\hline Texto original & Sugestão de tradução \\
\hline The show still looks exactly like when & O programa ainda tem a mesmíssima cara \\
you were sick with a really high fever and you & de quando cê tava doente ardendo de febre e ficou \\
\hline
\end{tabular}


stayed home to watch TV all day. It's not Let's

Make a Deal. It's not Wheel of Fortune. It's not Monty Hall, or the show with Pat Sajak. It's that other show where the big, loud voice calls your name in the audience, says to "Come on down, you're the next contestant," and if you guess the cost of Rice-A-Roni then you fly round-trip to live for a week in Paris. em casa pra ver TV o dia inteiro. Não é o Topa ou não Topa. Não é o Roda a Roda. Não é o Monty Hall, nem aquele programa com o Pat Sajak. É aquele outro programa com um vozeirão que chama seu nome na plateia, diz "Desce aqui, você é o próximo participante", e se cê acertar o preço duma caixa de arroz instantâneo da Rice-ARoni, voa com tudo pago pra passar uma semana em Paris.

Os game shows mencionados no início do conto são muito tradicionais e populares na TV norte-americana: o primeiro, Let's make a deal, está em exibição desde 1963, e o segundo, Wheel of fortune, desde 1975, ambos com bons índices de audiência até os dias de hoje. São, portanto, programas icônicos e muito conhecidos pelo leitor da cultura de partida, assim como o Show do milhão, Qual é a música? e Domingo legal seriam automaticamente reconhecidos pelos brasileiros, a partir de uma determinada faixa etária, mesmo que assistir tais programas não faça parte da rotina desses leitores. São referências que deixam muito claro, logo que o conto começa, de que tipo de programa o narrador está falando, o que é importante pois o nome do programa do qual ele participa nunca é dito, apesar de sabermos que se trata do The price is right (no Brasil exibido, tanto pelo SBT quanto pela Rede Record, como O preço certo).

Logo em seguida ele menciona também dois dos apresentadores mais famosos da televisão dos EUA: Monty Hall, ator e produtor de televisão canadense, famoso por ser um dos criadores do Let's make a deal, que apresentou durante mais de vinte anos; e Pat Sajak, apresentador do programa Wheel of fortune há mais de trinta anos. Na tradução, nossa estratégia foi a de traduzir os nomes dos programas para que o leitor brasileiro conseguisse de imediato fazer a associação com esse tipo específico de programa que auditório, assim como faria o leitor do texto de partida. Como o Let's make a deal nunca teve uma versão brasileira exibida na TV aberta, escolhemos o programa Topa ou não topa, que tem uma premissa levemente parecida e ficou conhecido nos anos 2000, com o apresentador Silvio Santos. Já o Wheel of fortune possui versão brasileira, o Roda a roda, nome que usamos, apresentada por Silvio Santos também e exibida pelo SBT desde 2003. Uma vez que o leitor já sabe que o tema do conto envolve game shows dessa natureza, fica mais fácil para ele compreender que Monty Hall e Pat Sajak são apresentadores, mesmo que não os conheça previamente, além de fazer uma ponte entre a cultura de 
chegada, com os nomes dos programas brasileiros, e a de partida, com os apresentadores da TV norte-americana.

Ao fim do parágrafo, temos ainda o caso do Rice-A-Roni, uma marca de arroz instantâneo de fácil preparo: basta fritar o arroz na manteiga, adicionar duas xícaras de água e o tempero, que já vem pronto em um sachê nos mais diversos sabores, e deixar cozinhar por quinze minutos. É algo como o macarrão instantâneo que conhecemos popularmente por "miojo", devido ao nome da empresa que trouxe o produto ao Brasil em 1965, a Myojo, mais tarde comprada pela Nissin ${ }^{60}$. Em todo caso, a marca Rice-ARoni não é comercializada no Brasil e, logo, não faz parte do dia-a-dia do brasileiro de forma que ele pudesse facilmente identificar o produto no texto ou saber, ao menos, que se trata de arroz. Por esse motivo, decidimos explicar o que é o produto antes do nome da marca, tentando fazer uma "caixa de arroz instantâneo da Rice-A-Roni”" soar tão natural quanto se disséssemos "uma caixa de leite da Piracanjuba" ou "um pacote de biscoito da Bauducco".

[2] Em sequência, temos um exemplo de uma atividade tradicional das universidades norte-americanas.

\begin{tabular}{|l|l|}
\hline \multicolumn{1}{|c|}{ Texto original } & \multicolumn{1}{|c|}{ Sugestão de tradução } \\
\hline \multicolumn{1}{|c|}{ It's Rush Week, and the tradition is } & \multicolumn{1}{|c|}{ É a Semana de Recrutamento das } \\
everybody pledging Zeta Delt all take this big & $\begin{array}{l}\text { fraternidades e é tradição a galera que tá tentando } \\
\text { chartered school bus and need to go to some TV } \\
\text { entrar pra Zeta Delta fretar esse busão escolar e ir } \\
\text { studio and watch them tape this game show. }\end{array}$ \\
& $\begin{array}{l}\text { num estúdio de TV onde eles gravam esses game } \\
\text { shows. }\end{array}$ \\
\hline
\end{tabular}

Segundo o site campusexplorer.com,

Rush week, oficialmente mais conhecida como recruitment week [semana de recrutamento], é o período em que as fraternidades e irmandades recrutam estudantes para suas respectivas organizações gregas. A semana de recrutamento geralmente acontece logo no início do ano letivo. ${ }^{61}$

Essa semana de recrutamento, porém, não faz parte da nossa cultura, e, apesar do conhecimento médio que os leitores podem ter da vida acadêmica norte-americana, em especial devido a quantidade de filmes hollywoodianos que retratam esse cenário, a

\footnotetext{
60 Disponível em: http://hashitag.com.br/por-que-o-macarrao-instantaneo-e-chamado-de-miojo/. Acesso em fevereiro de 2017.

61 Disponível em: http://www.campusexplorer.com/college-advice-tips/4B209587/What-is-Rush/. Acesso em junho de 2016.
} 
expressão "rush week" pode até ser mencionada com frequência, mas nunca posta em evidência (nunca aparece em legendas ou nas dublagens) para que seja de nosso conhecimento comum. Por esse motivo, optamos por uma tradução levemente explicativa, pois ao contrário do significado fechado que "rush week" tem, "semana de recrutamento" poderia se tratar de recrutamento para uma série de atividades acadêmicas, ao que adicionamos "das fraternidades" para que ficasse claro. Por um lado, essa tradução significa uma perda para o leitor, já que, mais uma vez, ele será impedido de conhecer a expressão "rush week"; por outro lado, o que prezamos em nosso projeto de tradução, como já foi dito inúmeras vezes, foi o efeito, sendo mais importante que o leitor pudesse saber do que se trata do que ele soubesse o nome original dado a esse evento. Poderíamos, é claro, ter dito "É a rush week, semana de recrutamento das fraternidades", mas ao nosso ver tal explicação não se fundiu ao texto de forma natural, como acreditamos ter acontecido nas outras vezes que utilizamos esse recurso, e não há motivo para o jovem explicar do que se trata, pois ele está falando para um interlocutor que, teoricamente, já sabe.

[3] Temos aqui as que foram, muito provavelmente, as duas expressões mais difíceis de traduzir entre os quatro contos:

\begin{tabular}{|l|r|}
\hline \multicolumn{1}{|c|}{ Texto original } & Sugestão de tradução \\
\hline These are not the Gamma Grab’a & Eles não são os Gamas Mão-Boba. Não \\
Thighs. They're not the Lambda Rape'a Dates. & são os Lambdas Boa-Noite-Cinderela. Os Zeta \\
The Zeta Delts, they're who everybody wants to & Deltas são quem todo mundo quer ser. \\
be. & \\
\hline
\end{tabular}

Pesquisamos em gramáticas e sites na internet dedicados à língua inglesa e não conseguimos encontrar uma única referência ou explicação para esse tipo de estrutura, que aparenta transformar o que deveria ser um adjetivo em substantivo:

$$
\begin{gathered}
\text { Thigh grabber } \rightarrow \text { Grab'a thighs } \\
\text { Date raper } \rightarrow \text { Rape'a date }
\end{gathered}
$$

Não sabemos explicar o motivo de o autor ter escolhido dizer assim a não ser pelo fato de querer formar um substantivo e ser de seu feitio evitar estruturas convencionais. Qualquer que seja a razão, fato é que, independentemente da estrutura, traduzir todo o sentido que "thigh grabber" e "date raper" carregam não foi tarefa fácil. O primeiro é uma expressão usada para se referir a pessoas, em geral homens, que se aproveitam de espaços 
tumultuados e cheios de gente para apalparem alguém, em geral mulheres; a tradução literal seria algo como "agarrador de coxa". O segundo se refere a pessoas, também geralmente homens, que cometem o "date rape", ou seja, estupram pessoas que já conhecem e com quem já têm a possibilidade de envolvimento romântico e/ou sexual; seria o caso, por exemplo, de um jovem convidar uma amiga para sair, droga-la e estuprala. $\mathrm{O}$ "date rape" é comum em festas universitárias, onde há consumo excessivo de álcool e drogas, e são adicionadas às bebidas das vítimas, sem que elas saibam, drogas chamadas de "date rape drugs", caso do flunitrazepam e da cetamina que não possuem cor ou cheiro e pretendem dopar a pessoa, deixando-a paralisada e indefesa para que não possa evitar o abuso $^{62}$. A expressão foi popularizada no início dos anos 1990 por conta de uma música da banda Sublime chamada Date rape, sobre uma moça drogada em um bar e estuprada, que no dia seguinte denuncia o abusador, que vai preso e é estuprado na cadeia.

Para a tradução, tentamos manter algo semelhante a estrutura escolhida pelo autor, o que só foi possível com o uso de hífen para transformar as palavras em um único substantivo. Para "grab'a thigh", escolhemos usar "mão-boba", que, apesar de não transmitir essa ideia de apalpar alguém em lugar fechado, dá, pelo menos, a noção de um toque que não é bem-vindo para quem o recebe. E, no caso de "rape'a date", usamos o nome informal em português dado às "drogas de estupro", o Boa noite, Cinderela, que também não deixa claro que o estuprador seria alguém que a vítima conhece, mas esperamos que o leitor possa fazer essa conexão, por se tratar de jovens estudantes que utilizarão essas drogas, provavelmente, nas festas que acontecem no campus.

[4] E, por fim, os últimos comentários de tradução:

\begin{tabular}{|c|c|}
\hline Texto original & Sugestão de tradução \\
\hline $\begin{array}{l}{[\ldots] \text { Ask the round-trip fare to Cabo for spring }} \\
\text { break. Down to the penny, you can tell them the } \\
\text { price of decent seats for the Panic at the Disco! } \\
\text { reunion tour. }\end{array}$ & $\begin{array}{l}\text { [...] Perguntem o preço da passagem de ida e volta } \\
\text { pra Cabo no spring break. Cê pode dizer até os } \\
\text { centavos do valor de lugares decentes pra turnê de } \\
\text { volta do Panic at the Disco!. }\end{array}$ \\
\hline $\begin{array}{l}\text { They should ask you the price of a Long } \\
\text { Island Iced Tea. The price of Marcia Sanders's } \\
\text { abortion. Ask about your expensive herpes } \\
\text { medication you have to take but don't want your }\end{array}$ & $\begin{array}{l}\text { Eles deviam te perguntar o preço dum Long Island } \\
\text { Iced Tea. O preço do aborto da Marcia Sanders. } \\
\text { Perguntar o preço do remédio caro pra herpes que } \\
\text { cê tem que tomar, mas não quer que seus pais }\end{array}$ \\
\hline
\end{tabular}

${ }^{62} \mathrm{O}$ site do governo dos EUA www.girlshealth.gov, dedicado a fornecer informações importantes sobre saúde e bem estar para garotas, tem um tópico muito elucidativo advertindo mulheres contra esse tipo de abuso. Disponível em: https://www.girlshealth.gov/safety/saferelationships/daterape.html. Acesso em novembro de 2016. 
folks to know you need. Ask the price of your History of European Art textbook which cost three hundred bucks - fuck you very much. saibam que você precisa. Perguntar o preço do seu livro teórico de História da Arte Europeia que custa trezentos dólares - obrigada de nada, seus bostas.

"Spring break" é uma semana de recesso acadêmico que acontece em todas as universidades e maioria das escolas norte-americanas durante a primavera, normalmente no mês de março, desde a década de 1930. É costume entre os jovens estudantes viajarem para locais como Las Vegas, Miami, Punta Cana, Cancun, Cabo, entre outros, para festivais destinados ao Spring Break, com festas, shows e outras atrações. Seria como a "semana do saco cheio" que temos no Brasil, mas com uma tradição muito mais enraizada e levada a sério do que aqui. Os festivais do Spring Break já se tornaram mundialmente famosos, inclusive atraindo turistas jovens de todo o mundo. Por esse motivo, é justificável a escolha de manter o nome do feriado em inglês, pois já tem notoriedade internacional, e traduzi-lo para "férias de primavera" ou "recesso de primavera" estaria sujeito ao risco de não causar no leitor, que já está acostumado a ouvir falar do evento como Spring Break, essa associação.

Quanto ao Long Island Iced Tea, é um dos coquetéis mais famosos do mundo por causa da quantidade de destilados utilizados em sua confecção: ele leva tequila, rum, vodca, gim, triple sec, suco de laranja e Coca-Cola. O nome se deve a ter sido criado em Long Island, um distrito localizado ao sul da Califórnia. Não seria o caso de traduzir por "Chá gelado de Long Island” porque, dessa forma, seria impedida a associação do leitor com o drink mundialmente conhecido por seu nome original, por isso o mantivemos.

Por fim, a expressão "fuck you very much" representa uma junção de "fuck you" com "thank you very much", uma interjeição irônica do narrador para expressar seu descontentamento com o preço absurdo do livro acadêmico. Em português, optamos por usar uma expressão informal, nascida das redes sociais, que carrega esse tom ácido e irônico, que em geral finalizam depoimentos com críticas a algo ou alfinetadas, o "obrigada, de nada", e, para não deixar de fora o palavrão "fuck", que demonstra um tom de raiva que "obrigada, de nada" sozinho não transmite, acrescentamos "seus bostas" ao fim.

Nesse capítulo, foi possível (re)pensar nossa tradução, através do exercício de justificar as decisões que tomamos. Por diversas vezes, ao tentar explicar de que forma chegamos a determinado resultado, tivemos a oportunidade de rever nossas escolhas e 
revisar nossas traduções. A partir desses comentários, pusemos à prova as estratégias que havíamos desenvolvido para o projeto de tradução, o que serviu para estrutura-las e solidifica-las ainda mais, dando-nos confiança de que são, acima de tudo, funcionais. Por esse motivo, a tradução crítica e comentada constitui um exercício de grande importância e utilidade à tarefa a que se propõe o tradutor. 


\section{CONSIDERAÇÕES FINAIS}

Nessa pesquisa de mestrado, propusemo-nos a fazer uma introdução ao elemento transgressivo e ao seu papel no texto literário através dos anos, em uma tentativa de mostrar que não se trata de componente exclusivo da literatura contemporânea ou da ficção transgressiva atual. Tínhamos, por objetivo o desenvolvimento de um projeto de tradução que representasse o tex to transgressivo, a partir da tradução de quatro contos do autor norte-americano Chuck Palahniuk: "Knock-knock", "How Monkey got married, bought a house and found happiness in Orlando", "Zombies" e "Loser", todos extraídos da obra Make something up: stories you can't unread (2015).

Primeiramente, foram apresentados alguns aspectos textuais e ideológicos que permeiam a transgressão na literatura, tendo como principal base teórica Michel Foucault (1999; 2009), M. Keith Booker (1991) e Robin Mookerjee (2013), além das noções de carnaval de Mikhail Bakhtin (1999). De um modo geral, os autores nos fizeram enxergar a transgressão como um movimento de união e conexão entre pessoas que se localizam às margens sociais, muito mais que simples rompimento com leis e normas de instituições de poder. O texto transgressivo é problematizador, satírico, irônico, exagerado, ofensivo e aborda temas que a sociedade prefere ignorar, além de ser um texto sobre personagens periféricas e diminutas consumido também pelas elites culturais, o que lhe confere grande alcance crítico.

Em seguida, traçamos um panorama da literatura norte-americana a partir dos anos 1950, para identificar o momento do surgimento de obras com caráter transgressivo. Foi possível perceber que a combinação de fatores fim da II Guerra Mundial, mais início da Guerra Fria com ameaça de confronto nuclear a qualquer momento, juntamente com a prosperidade econômica que transforma os EUA em potência, intensificados pela Guerra do Vietnã, fez com que surgissem, entre os anos 1950 e 1990, manifestações artísticas e sociais de revolução. Na literatura, as obras com caráter transgressivo, nas ruas os movimentos de contracultura. Ao concluir esse panorama com os anos 1990, voltamos o foco do trabalho para Chuck Palahniuk, sua biografia, bibliografia e análise de sua escrita. A isso, seguiu-se a introdução de sua obra mais recente, Make something up: stories you can't unread (2015), com breve apresentação e análise de cada um dos contos traduzidos.

No segundo capítulo, tivemos a oportunidade de pensar como se dá a tradução de um texto transgressivo. Em primeiro lugar, admitimos se tratar de tradução de texto sensível e cogitamos a hipótese de toda tradução ser, automaticamente, um ato de 
violência e transgressão, tanto com a obra quanto com o público, por operar mudanças inevitáveis no texto, e, às vezes, no leitor, sejam elas boas ou ruins. Iniciamos, também, o esboço de um projeto de tradução, estabelecendo que buscaríamos executar uma tradução que colocasse o leitor em contato com o outro, transportasse-o à cultura de partida para que pudesse, assim, confrontar a sua própria.

A fim de compreender a posição da ficção transgressiva e da ficção transgressiva traduzida no polissistema literário para, assim, identificar que fatores motivam sua tradução, valemo-nos da Teoria dos Polissistemas, de Itamar Even-Zohar (1990), e dos Estudos Descritivos da Tradução, de Gideon Toury (1995). Conseguimos descobrir o que acontecia na literatura brasileira na década de 1990, percebendo como foi influenciada pela produção intelectual norte-americana, exportada em massa a partir dos anos 1960, e localizar um público alvo que justifique a tradução dessas obras transgressivas.

Para desenvolver ainda mais nosso projeto de tradução, estudamos os gêneros que qualificam nossos textos, conto e fábula, ao que percebemos que alguns aspectos do gênero textual, como a brevidade e força da unidade de impressão do conto e linguagem didática da fábula, de fato influenciam a tradução, guiando estratégias utilizadas no projeto, mas são, de um modo geral, menos relevantes para o resultado final do que previmos inicialmente, pois são estratégias que surgem de um impulso quase instintivo de traduzir esse tipo de texto, não estando necessariamente ligado a um estudo analítico de gênero.

Ademais, levamos em conta outros desafios que os textos apresentaram, em especial a tradução da oralidade na narrativa, tradução de elementos cômicos e a tradução de marcadores culturais. Percebemos, ao fim das reflexões teóricas que fizemos envolvendo todas essas questões, que teríamos que articular estratégias voltadas para uma tradução funcional e criativa, que se posicionasse como tradução, colocasse em evidência a cultura e sociedade de partida, mas que, ao mesmo tempo, também soasse fluido e natural na língua portuguesa, para permitir a aproximação e identificação do leitor com o texto em nível suficiente para que este percebesse a crítica social inserida na narrativa e construísse seu próprio pensamento crítico.

No último capítulo, mostramos como colocamos tais estratégias de tradução na prática. Foi um exercício de análise crítica da nossa tradução, com comentários e explanações acerca de decisões que tomamos, que se mostrou deveras útil e engrandecedor. Foi apenas nesse momento que de fato conseguimos ter uma noção concreta do que era esse projeto de tradução que havíamos desenvolvido, tendo a 
oportunidade de revisar as traduções e ajustá-las a este propósito. Acreditamos que, ao que nos propusemos fazer, as traduções foram bem-sucedidas.

No início da pesquisa, questionamos a função de agente social que a ficção transgressiva alegava ter, indagando se, hoje em dia, o gênero ainda estaria comprometido com mudanças sociais e se seria capaz de estimular seus leitores a operá-las ou, no mínimo, desenvolver um pensamento crítico. Após estudar a trajetória da transgressão e da obra de Palahniuk, em particular, bem como ler, analisar e traduzir seus textos, podemos afirmar que sim, a ficção transgressiva ainda detém essa função. A crítica social, a sátira carnavalesca, a ironia, a problematização, e evidenciação de mazelas etc., ainda estão presentes, esperando uma chance de estourar a bolha em que vivemos. Se, entretanto, o texto for lido apenas como entretenimento, ele ainda configura função de agente social, pois, em se tratando do público leitor desse tipo de obra (como vimos em uma das entrevistas com Palahniuk, seus leitores costumam ser homens jovens que não possuem hábito de leitura) qualquer coisa que os faça ler e que se proponha a tirá-los de sua zona de conforto já está operando mudança social.

Outra reflexão que se desenvolveu durante o trabalho de pesquisa e tradução foi a de se a tradução é transgressiva por se tratar de um texto transgressivo ou se por si só não seria um ato de transgressão. Em outras palavras, é transgressiva a tradução ou o objeto? É interessante pensar de que forma se dá uma tradução transgressiva, se toda tradução o é, se isso acontece de forma instintiva, se depende do texto traduzido, se há estratégias que a tornem mais ou menos transgressiva, se a tradução a que chegamos no fim do projeto é transgressiva ou só o texto o é. São inúmeras perguntas para as quais não temos resposta certa, pois não foi possível chegar a uma conclusão definitiva a respeito, mas o que se pode afirmar que toda tradução tem potencial transgressivo, que será potencializado quando o tradutor se propuser a produzir um texto que tire o leitor de sua zona de conforto, que provoque nele o senso crítico. E essa possibilidade, é claro, não está limitada a textos do gênero transgressivo, ou seja, ao objeto, pois, como vimos com M. Keith Booker (1991) todo texto literário pode ser lido como transgressivo; o fato do autor e obra selecionados para a pesquisa de mestrado se encaixarem no gênero apenas contribuiu para que se levantasse a hipótese de que a transgressão na tradução ultrapassa questões de gênero literário e temática. Essas questões iniciam uma discussão muito relevante para os Estudos da Tradução e precisam ser revistas e debatidas mais a fundo em pesquisas futuras. 


\section{REFERÊNCIAS BIBLIOGRÁFICAS}

ALVES, Marco Antônio Sousa. “A escrita literária em Foucault: da transgressão à assimilação". Em tese, Belo Horizonte. n. 1, v. 19, p. 12-28, jan/abr. 2013.

ANNESLEY, James. Blank fictions. Nova York: St. Martin’s Press, 1998.

ARAGÃO, Maria Lúcia. “Gêneros Literários”. Em SAMUEL, Roger (org.). Manual de teoria literária. Petrópolis: Vozes, 1985.

BAKHTIN, Mikhail M. Problemas da Poética de Dostoiévski. Trad. Paulo Bezerra. $1^{\text {a }}$. ed. Rio de Janeiro: Forense Universitária, 1981.

A cultura popular na Idade Média e no Renascimento: o contexto de François Rabelais. São Paulo: Hucitec, 1999.

BOOKER, M. Keith. Techniques of subversion in modern literature: transgression, abjection and the carnivalesque. Florida: University of Florida Press, 1991.

BRITTO, Paulo Henriques. A tradução literária. 1. ed. Rio de Janeiro: Civilização Brasileira, 2012.

CAMPOS, Haroldo de. Transcriação. Marcelo Tápia, Thelma Médici Nóbrega (orgs.).

São Paulo: Perspectiva, 2013.

CORTÁZAR, Julio. “Alguns aspectos do conto". Em Valise de cronópio. Tradução de Davi Arrigucci Jr. e João Alexandre Barbosa. 2. ed. São Paulo: Perspectiva, 1993.

EAGLETON, Terry. Walter Benjamin, or towards a revolutionary criticism. London: Verso Books, 1981.

EVEN-ZOHAR, Itamar. Polysystem studies. In: Poetics today: international journal for theory and analysis of literature and communication. v. 11. n. 1. Durham NC: Duke University Press, 1990.

FERES, Lilia Baranski. “Tradução: entre a transgressão e o narcisismo”. Em: Seminário brasileiro de estudos culturais e educação, 6., Canoas. A 2015.

FOUCAULT, Michel. Prefácio à transgressão. In: FOUCAULT, M. Estética: literatura e pintura, música e cinema. Tradução de Inês Autran Dourado Barbosa. 2 ed. Rio de Janeiro: Forense Universitária, 2009, p. 28-46. 
FOUCAULT, Michel. Vigiar e punir. Tradução de Raquel Ramalhete. $20^{\mathrm{a}}$ ed. Petrópolis: Vozes, 1999.

FRIEDMAN, Norman. O que faz um conto ser curto? Tradução de Marta Cavalcante de Barros. Revista USP, São Paulo, m. 63, p. 219-230, set./nov. 2004.

GUIMARÃES, Felipe F. F. Traços da contracultura brasileira da década de 1960: um estudo comparado entre movimentos contraculturais nos Estados Unidos e no Brasil. XVIII Encontro Regional ANPUH-MG. Mariana: julho de 2012.

HALliWELL, Martin. American culture in the 1950s. Edinburgh: Edinburgh University Press, 2007.

HARRISON, Colin. American culture in the 1990s. Edinburgh: Edinburgh Umiversity Press, 2010.

HERMANS, Theo (ed.). The Manipulation of Literature: Studies in Literary Translation. London: Croom Helm, 1985. p. 42-53.

KAVADLO, Jesse. "The fiction of self-destruction: Chuck Palahniuk, closet moralist". In: GRAYSON, Erik M. (Ed.). Stirrings still: the international journal of existential literature. v. 2. n. 2. Binghamton: Binghamton University, 2005.

LANDERS, Clifford E. Literary translation: a practical guide. Clevedon: Multilingual Matters, 2001.

LAPLANTINE, François; NOUSS, Alexis. A mestiçagem. Trad. Ana Cristina Leonardo. Lisboa: Instituto Piaget, 2004.

LEPPIHALME, Ritva. Culture bumps: an empirical approach to the translation of allusions. Clevedon: Multilingual Matters, 1997.

LOPES, Mariú Moreira Madureira. A sensibilidade na tradução de textos sagrados. Em: Revista Todas as letras N, v. 11, n. 2. São Paulo: UPM, 2009.

MACGOWAN, Christopher. The twentieth-century American fiction handbook. Malden: Wiley-Blackwell, 2011.

MARTINS, Marcia A. P. A instrumentalidade do modelo descritivo para a análise de traduções: O caso dos Hamlets brasileiros. Tese de doutorado em Comunicações e Semiótica. São Paulo: PUC, 1999. 
MOOKERJEE, Robin. Transgressive fiction: the new satiric tradition. New York: Doubleday, 2013.

NEWMARK, Peter. A Textbook of Translation. New York and London: Prentice Hall, 1988.

PALAHNIUK, Chuck. Clube da luta. Tradução de Cassius Medauar. 1. ed. São Paulo: Leya, 2012.

Fight club. New York: Norton \& Company, 2005.

Make something up: stories you can't unread. New York:

Palgrave Macmillan, 2013.

PAZ, Octavio. Tradução: literatura e literalidade. Tradução: Doralice Alves de Queiroz. Belo Horizonte: FALE/ UFMG, 2009.

PRETI, Dino. Estudos de língua oral e escrita. Rio de Janeiro: Lucerna, 2004.

POE, Edgar Allan. "A filosofia da composição". Em Poemas e ensaios. Tradução de Oscar Mendes e Milton Amado. Rio de Janeiro: Globo, 1987, pp. 109-122.

PORTELLA, Oswaldo. A fábula. Em: Revista Letras. v. 32. Curitiba: UFPR, 1983, p. 119-138.

POWERS, Stephen. “Chuck Palahniuk”. In: JARVIS, Zeke (ed.). Make 'em laugh!: American humorist of the 20th e 21st centuries. Santa Barbara: Greenwood, 2015, p. 2426.

QUEIROZ, Bianca Rodrigues Bold. Tradução de Humor: Limites e Possibilidades. Em Revista ao pé da letra, v. 9. Recife: UFPE, 2007.

RAJAGOPALAN, Kanavillil. "Traição versus transgressão: reflexões acerca da tradução e pós-modernidade”. Em: Alfa. n. 44 (v. esp.). São Paulo: UNESP, 2000, p. 123-130.

ROSAS, Marta. Tradução de humor: transcriando piadas. Rio de Janeiro: Editora Lucerna, 2002.

SCHMITZ, John Robert. Humor: É possível traduzi-lo e ensinar a traduzi-lo? Em: TradTerm - Revista do Centro Interdepartamental de Tradução e Terminologia, v. 3. São Paulo: FFLCH, USP, 1996, p. 87-97. 
Sobre a tradução e o ensino: o humor levado a sério. Em:

TradTerm - Revista do Centro Interdepartamental de Tradução e Terminologia, v. 5, n. 2. São Paulo: FFLCH, USP, 1998, p. 41-54.

SCHOLLHAMMER, Karl Erik. Ficção brasileira contemporânea. Rio de Janeiro: Civilização brasileira, 2009.

TOURY, Gideon. "The nature and role of norms in translation". In Discriptive Tanslation Studies and Beyond. Amsterdam/Philadelphia: John Benjamins, 1995, p. 53-69.

VENUTI, Lawrence. The scandals of translation: towards an ethics of difference. London: Routledge, 1998, p. 124-58.

WELSH, Irvine. Trainspotting. London: Vintage Books, 2001. 


\section{ANEXO A}

\section{"Knock-knock"}

My old man, he makes everything into a Big Joke. What can I say? The old man loves to get a laugh. Growing up, half the time I didn't have a clue what his jokes were about, but I laughed anyways. Down at the barbershop, it didn't matter how many guys my father let take cuts ahead of him in line, he just wanted to sit there all Saturday and crack people up. Make folks bust a gut. Getting his hair cut was definitely a low priority.

He says, "Stop me if you've heard this one before..." The way my old man tells it, he walks into the oncologist's office and he says, "After the chemotherapy, will I be able to play the violin?"

In response, the oncologist says, "It's metastasized. You've got six months to live..."

And working his eyebrows like Groucho Marx, tapping the ash from an invisible cigar, my old man says, "Six months?" He says, "I want a second opinion."

So the oncologist, he says, "Okay, you've got cancer and your jokes stink."

\section{"Toc-toc"}

Meu coroa, tudo pra ele é uma Grande Piada. Que que eu posso dizer? O cara adora dar umas risadas. Quando eu era mais novo, quase nunca tinha ideia do que as piadas queriam dizer, mas eu ria de qualquer jeito. Na barbearia, não importava quantos caras meu pai deixava passar na frente pra cortar o cabelo, ele só queria sentar lá o sábado inteiro e matar todo mundo de rir. Fazer o povo gargalhar até explodir. Cortar o cabelo definitivamente não era prioridade.

Ele diz, "Me interrompe se cê já tiver ouvido essa..." Do jeito que o coroa conta, ele entra no consultório do oncologista e diz, "Depois da quimioterapia, eu vou conseguir tocar violino?"

Em resposta, o oncologista diz, "Ele se espalhou. Cê tem seis meses de vida..."

E mexendo as sobrancelhas tipo o Groucho Marx, batendo as cinzas dum charuto invisível, o coroa ele diz, "Seis meses?" Ele diz, "Eu quero uma segunda opinião".

Daí o oncologista, ele diz, "Ok, cê tem câncer $e$ suas piadas são podres". 


\begin{tabular}{|c|c|}
\hline $\begin{array}{l}\text { So they do chemotherapy, and they give him some radiation like } \\
\text { hey do even if the shit burns him up so bad on the inside he tells me } \\
\text { hat taking a piss is like passing razor blades. He's still every Saturday } \\
\text { lown by the barbershop telling jokes even if now he's bald as a cue } \\
\text { all. I mean, he's skinny as a bald skeleton, and he's getting to haul } \\
\text { around one of those cylinders of oxygen under pressure, like some little } \\
\text { yersion of a ball-and-chain. He walks into the barbershop dragging that } \\
\text { oressurized cylinder of oxygen with the tube of it going up and looping } \\
\text { around his nose, over his ears, and around his bald head, and he says, } \\
\text { 'Just a little off the top, please." And folks laugh. Understand me: My } \\
\text { ld man is no Uncle Milty. He's no Edgar Bergen. The man's skinny } \\
\text { s a Halloween skeleton and bald and going to be dead by six weeks so } \\
\text { t don't matter what he says, folks are going to hee-haw like donkeys } \\
\text { ust out of their genuine affection for him. }\end{array}$ & $\begin{array}{l}\text { se essa porra queima ele tanto por dentro que ele me diz que parece que } \\
\text { tão saindo lâminas quando ele mija. Ele ainda tá todo sábado lá na } \\
\text { barbearia contando piadas, mesmo agora tando careca como uma bola } \\
\text { de sinuca. É tipo, ele tá magrelo como um esqueleto careca e tem que } \\
\text { arrastar por aí um daqueles cilindros de oxigênio sob pressão, que nem } \\
\text { uma versão menor da bola com corrente de ferro dum presidiário. Ele } \\
\text { entra na barbearia arrastando aquele cilindro pressurizado de oxigênio } \\
\text { com o tubo subindo e passando em volta do seu nariz, por cima das } \\
\text { orelhas e ao redor da careca e diz, "Tira só um pouquinho do topete, } \\
\text { por favor". E o pessoal ri. Olha só: meu coroa não é nenhum Uncle } \\
\text { Milty. Nenhum Edgar Bergen ou qualquer um desses comediantes. O } \\
\text { homem tá magro como um esqueleto de Halloween e careca e vai } \\
\text { morrer daqui seis semanas, então não importa o que ele diz, os caras } \\
\text { vão rir que nem jumentos só pelo afeto genuíno que têm por ele. } \\
\text { Mas, sério mesmo, eu não tô fazendo jus. É culpa minha se não } \\
\text { ficou claro, mas meu coroa é mais engraçado do que parece. Talvez o } \\
\text { senso de humor dele seja um talento que eu não herdei. Na época que } \\
\text { eu era o bonequinho dele, feito o Charlie McCarthy, o tempo todo } \\
\text { enquanto eu crescia, ele me perguntava, "Toc-toc?" }\end{array}$ \\
\hline
\end{tabular}




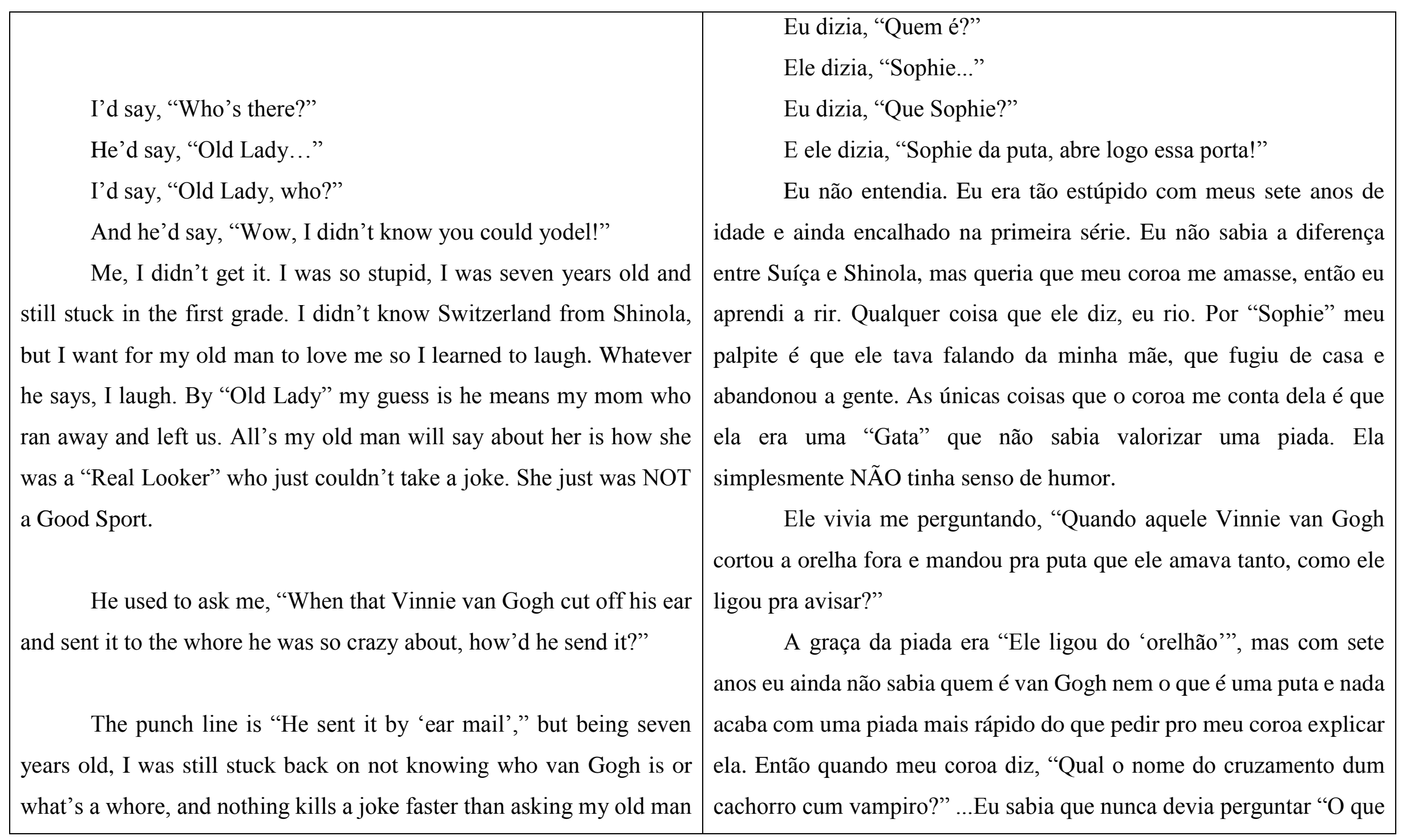


to explain himself. So when my old man says, "What do you get when you cross a pig with Count Dracula?"...I knew to never ask, "What's a 'Count Dracula'?' I'd just get a big laugh ready for when he tells me, "A 'Ham-pire'!"

And when he says, "Knock-knock..."

And I say, "Who's there?" And he says, "Radio."

And I say, "Radio who?" And he's ALREADY started to bust a gut when he says, "Radio not I'm going to cum in your mouth..." Then-what the hell-I just keep laughing. My whole growing up I figure I'm just too ignorant to appreciate a good joke. Me, my teachers still haven't covered long division and all the multiple-cation tables so it's not my old man's fault I don't know what's "cum."

My old lady, who abandoned us, he says she hated that joke so maybe I inherited her lack of humor. But love... I mean you have to love your old man. I mean, after you're born it's not like you get a choice. Nobody wants to see their old man breathing out of some tank and going into the hospital to die skyhigh on morphine and he's not eating a bite of the red-flavored Jell-O they serve for dinner. é um 'vampiro'?”, e só preparava uma grande gargalhada pra quando ele dissesse "Cãode Drácula!".

E quando ele diz, "Toc-toc..."

E eu digo, “Quem é?" E ele diz, "Fifi”.

E eu digo, “Que Fifi?” E ele JÁ tá se contorcendo de rir quando diz, "Fifica esperto que eu vou gozar na sua boca..." E daí — foda-se — eu só continuo rindo. Minha infância inteira eu concluo que eu sou simplesmente ignorante demais pra dar valor pruma boa anedota. Eu, meus professores ainda nem ensinaram a dividir grandes valores nem a tabuada de multiplacanção, então não é culpa do meu coroa se eu não sei o que é "gozar".

Ele conta que a minha mãe, que abandonou a gente, detestava essa piada, então pode ser que eu tenha herdado a falta de senso de humor dela. Mas amor... quer dizer, cê tem que amar o seu coroa. Quer dizer, depois que cê nasce, não é como se tivesse escolha. Ninguém quer ver o pai respirando por um tanque e ir pro hospital morrer doidão de morfina e sem comer uma colher que seja da gelatina sabor vermelho que eles servem no jantar.

Me interrompe se eu já tiver contado essa: mas meu coroa tá com aquele câncer de próstada que num é nem um câncer de verdade 
Stop me if I already told you this one: but my old man gets that prostrate cancer that's not even like cancer because it takes twenty, thirty years before we even know he's so sick, and the next thing I know is I'm trying to remember all the stuff he's taught me. Like, if you spray some WD-40 on the shovel blade before you dig a hole the digging will go a lot easier. And he taught me how to squeeze a trigger instead of pulling it and wrecking my aim. He taught me to remove bloodstains. And he taught me jokes...lots of jokes.

And, sure, he's no Robin Williams, but I watched this movie one time about Robin Williams who gets dressed up with a red rubber ball on his nose and this big rainbow-colored afro wig and those big clown shoes with a fake carnation stuck in his buttonhole of his shirt that squirts water, and the guy's a hotshot doctor who makes these little kids with cancer laugh so hard they stop dying. Understand me: These bald kid skeletons - who look worse off than my old man - they get HEALTHY, and that whole movie is based on a True Story.

What I mean is, we all know that Laughter is the Best Medicine. All that time being stuck in the hospital Waiting Room, even I read the porque leva vinte, trinta anos até a gente descobrir que ele tá doente desse tanto e minha primeira reação é tentar lembrar de tudo que ele me ensinou. Tipo, se cê passar um pouco de WD-40 na lâmina da pá antes de cavar um buraco, vai ser bem mais fácil de cavar. E ele me ensinou que cê tem que apertar o gatilho ao invés de puxar pra não cagar sua mira. Ele me ensinou a tirar manchas de sangue. E me ensinou piadas... muitas piadas.

E, claro, ele não é nenhum Robin Williams, mas uma vez eu assisti esse filme do Robin Williams que se fantasia com uma bola de borracha vermelha no nariz e uma perucona africana das cores do arcoíris e aqueles sapatos enormes de palhaço com uma margarida falsa presa na lapela da camisa que esguicha água, e o cara é um médico figurão que faz as criancinhas com câncer rirem tanto que elas param de morrer. Vê se cê me entende: Esses mini esqueletos carecas, que tão com uma cara pior que a do meu coroa, ficam SAUDÁVEIS e o filme inteiro é baseado em Fatos Reais.

O que eu quero dizer é, todo mundo sabe que o Riso é o Melhor Remédio. Aquele tempo todo que eu passei na Sala de Espera do hospital, até eu li a Reader's Digest. E todo mundo já ouviu a história verídica do cara com um câncer no cérebro do tamanho duma laranja 
Reader's Digest. And we've all heard the true story about the guy with a brain cancer the size of a grapefruit inside his skull and he's about to croak - all the doctors and priests and experts say he's a goner-only he forces himself to watch nonstop movies about the Three Stooges. This Stage Four cancer guy forces himself to laugh nonstop at Abbott and Costello and Laurel and Hardy and those Marx brothers, and he gets healed by the end-orphans and oxy-generated blood.

So I figure, what've I got to lose? All I need to do is remember some of my old man's favorite gags and get him started back laughing on the road to recovery. I figure, what could it hurt?

So this grown-up son walks into his father's hospice room, pulls up a chair beside the bed, and sits down. The son looks into his old man's pale, dying face and says: "So this blond gal walks into a neighborhood bar where she's never been before, and she's got tits out to HERE and a tight little heinie and she asks the bartender for a Michelob, and he serves her a Michelob, except he sneaks a Mickey Finn into her bottle and this blonde goes unconscious, and every guy in the bar leans her over the edge of the pool table and hikes up her skirt and fucks her, and at closing time they slap her awake and tell her she's que tá quase batendo as botas — todos os médicos e padres e especialistas dizem que ele já tá mais pra lá do que pra cá — só que ele se força a assistir sem parar filmes dos Três Patetas. Esse cara com câncer em estágio IV se força a rir sem parar do Abbott e do Costello e do Gordo e o Magro e daqueles irmãos Marx e ele é curado pelas emdores-finas e pelo sangue oxi-generado.

Daí eu penso, que que custa tentar? Tudo que eu tenho que fazer é me lembrar dumas das piadas preferidas do velho e fazer ele rir até se recuperar. Eu penso, que mal pode fazer?

Daí esse filho crescido entra no quarto da casa de repouso do pai, puxa uma cadeira ao lado da cama e senta. $O$ filho olha pro rosto pálido e mórbido do seu coroa e diz, "Daí essa mina loira entra num bar que ela nunca foi antes e ela tem umas tetas até AQUI e uma bocetinha apertada e ela pede uma Budweiser pro garçom e ele serve a Budweiser só que coloca um Boa-noite-Cinderela na garrafa sem ela ver e a loira apaga e todos os caras no bar botam ela na mesa de sinuca, levantam a saia dela e fodem ela, e no fim da noite dão uns tapas pra ela acordar e mandam ela embora. E de vez em quando essa mina dos peitões e do rabão entra e pede uma Budweiser e leva um Boa-noite-Cinderela de 
got to leave. And every few days this gal with the tits and the ass walks

in and asks for a Michelob and gets a Mickey Finn and gets fucked by the crowd until one day she walks in and asks the bartender, can he maybe give her a Budweiser instead?"

Granted-I have NOT landed this particular shaggy-dog story since I was in the first grade, but my old man used to love this next part...

The bartender smiles so nice and says, "What? You don't like Michelob no more?"

And this Real Looker, she leans over the bar, all confidential and she whispers, "Just between you and me..." she whispers, "Michelob makes my pussy hurt..."

The first time I learned that joke, when my old man taught it to me, I didn't know what was "pussy." I didn’t know “Mickey Finn.” I didn't know what folks meant when they talked about "fucking," but I knew all this talk made my old man laugh. And when he told me to stand up and tell that joke in the barbershop it made the barbers and every old man reading detective magazines laugh until half of them blew spit and snot and chewing tobacco out their noses. presente e é fodida pela galera toda até que um dia ela entra e pede pro garçom, me dá uma Corona hoje?"

Fato, eu NÃO contava essa piada longa e sem graça especificamente desde a primeira série, mas meu coroa amava essa próxima parte...

O garçom sorri todo simpático e diz, "Que foi? Cê não gosta mais de Bud?"

E essa Gostosa se debruça no bar toda confidente e sussurra, “Cá pra nós...” ela sussurra, “a Bud machuca minha pepeca”.

A primeira vez que eu aprendi essa piada, quando meu coroa me contou, eu não sabia o que era "pepeca". Eu não sabia o que era "Boa-noite-Cinderela". Eu não sabia o que os caras queriam dizer quando falavam em "foder", mas sabia que todo esse papo fazia meu coroa rir. E quando ele me mandou levantar e contar a piada na barbearia, ela fez os barbeiros e cada um dos velhos lendo romances policiais rirem até que metade deles jorrava cuspe e meleca e tabaco pelo nariz.

Agora o filho crescido conta a piada pro pai moribundo, só os dois sozinhos no quarto de hospital, tarde da noite, e - adivinha - o 


\begin{tabular}{|c|c|}
\hline $\begin{array}{l}\text { Now the grown-up son tells his old dying father this joke, just } \\
\text { the two of them alone in that hospital room, late-late at night, and- } \\
\text { guess what-his old man doesn't laugh. So the son tries another old } \\
\text { favorite, he tells the joke about the Traveling Salesman who gets a } \\
\text { phone call from some Farmer's Daughter he met on the road a couple } \\
\text { months before, and she says, "Remember me? We had some laughs, } \\
\text { and I was a good sport?" and the man says, "How're you doing?" and } \\
\text { she says, "I'm pregnant, and I'm going to kill myself." And the } \\
\text { salesman, he says, "Damn...you ARE a good sport!" } \\
\text { At seven years old I could REALLY put that joke over-but, } \\
\text { tonight the old man's still not laughing. How I learned to say "I Love } \\
\text { You" was by laughing for my old man-even if I had to fake it-and } \\
\text { that's all I want in return. All I want from him is a laugh, just one laugh, } \\
\text { and he's not coming across with even a giggle. Not a snicker. Not even } \\
\text { a groan. And worse than not-laughing, the old man squints his eyes } \\
\text { shut, tight, and opens them brimming with tears, and one fat tear floods } \\
\text { out the bottom of each eye and washes down each cheek. The old man's } \\
\text { gasping his big toothless mouth like he can't get enough air, crying big } \\
\text { tears down the wrinkles of both cheeks, just soaking his pillow. So this }\end{array}$ & $\begin{array}{l}\text { Com sete anos eu conseguia MESMO contar essa piada, mas } \\
\text { hoje o coroa continua não rindo. O jeito que eu aprendi de dizer "Eu Te } \\
\text { Amo" foi rindo pro meu coroa - mesmo se tivesse fingindo - e isso } \\
\text { é tudo que eu quero de volta. Tudo que eu quero dele é uma gargalhada, } \\
\text { só uma gargalhada, e ele não tá me dando nem uma risadinha. Nem um } \\
\text { sorrisinho. Nem mesmo um gemido. E pior do que não rir, o coroa fecha } \\
\text { bem os olhos e quando abre eles tão cheios de lágrimas e uma lágrima } \\
\text { gorda transborda da margem de cada olho e escorre por cada bochecha. } \\
\text { O coroa tá arquejando com a bocona banguela como se não conseguisse } \\
\text { respirar direito, as lágrimas gordas descendo pelas rugas das bochechas, } \\
\text { ensopando o travesseiro. Daí esse filho, que não é mais o bebê de } \\
\text { ninguém, mas não consegue esquecer essas piadas, enfia a mão no }\end{array}$ \\
\hline
\end{tabular}


forget these jokes, he reaches into his pants pocket and gets out a fake carnation flower that just-for-laughs sprays water all over the old crybaby's face.

The kid tells about the Polack who's carrying a rifle through the woods when he comes across a naked gal laying back on a bed of soft green moss with her legs spread, and this gal is a Real Looker, and she looks at the Polack and his gun and says, "What're you doing?" And the Polack says, "I'm hunting for game." And this Real Looker, she gives him a big wink and she says, "I'm game."

So-POW! - the Polack shoots her. It used to be this joke constituted a gold-plated, bona fide, sure-thing laugh riot, but the old man just keeps dying. He's still crying and not even making an effort to laugh, and no matter what, the old man has got to meet me halfway. I can't save him if he doesn't want to live. I ask him, "What do you get when you cross a faggot with a kike?" I ask him, "What's the difference between dog shit and a nigger?"

And he's still not getting any better. I'm thinking maybe the cancer's got into his ears. With the morphine and what all, it could be he can't hear me. So just to test, can he hear me, I lean into his crybaby face and I ask, "How do you get a nun pregnant?" Then, more loud, bolso da calça e tira uma margarida de mentira que só-de-zoeira espirra água na cara velha chorona inteirinha.

O menino conta do polonês que tava andando pela floresta com uma espingarda e encontra uma mina pelada deitada num monte macio de folhas verdes com as pernas abertas e ela é gata pra caralho e olha pro português com a arma e diz, "O que cê tá fazendo?" E o polonês diz, "Tô caçando comida". E a gostosa dá uma piscadinha e diz, "Pode vir me comer".

Daí - POW! - o polonês atira nela. Antigamente essa piada era garantia certa dum ataque de risos espontâneo banhado a ouro, mas o velho continua morrendo. Ele ainda tá chorando, sem fazer nenhum esforço pra rir e, custe o que custar, o coroa tem que fazer a parte dele. Eu não posso salvar ele se ele não quiser viver. Eu pergunto, "O que cê ganha quando cruza um viado e um judeu?" Eu pergunto, "Qual a diferença entre um negro e cocô de cachorro?"

E ele ainda não tá melhorando. Eu tô achando que o câncer pode ter afetado os ouvidos dele. Com a morfina e tal, vai ver ele não tá me ouvindo. Então só para testar se ele pode ouvir, eu me debruço em cima da cara chorona dele e pergunto, "Como cê engravida uma freira?" 


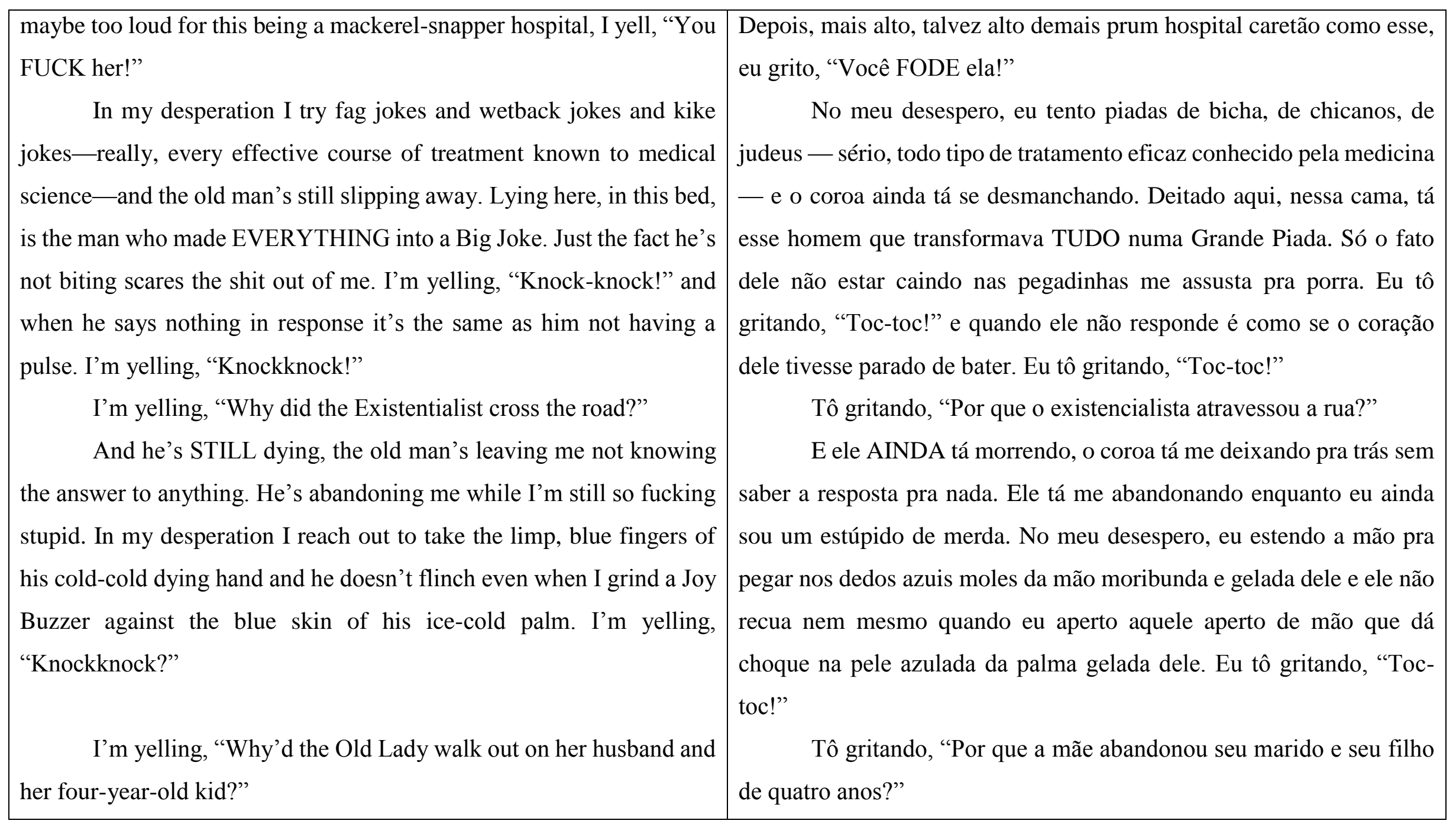


Nothing kills a joke like asking my old man to explain himself, and lying there in that bed, he stops breathing. No heartbeat. Totally flatlined.

So this kid who's sitting bedside in this hospital room, late-late at night he takes the joke equivalent of those electric paddles doctors use to stop your heart attack, the heehaw equivalent of what a paramedic Robin Williams would use on you in some Clown Emergency Room - a kind of Three Stooges defibrillator-the kid takes a big, creamy, heaped-up custard pie topped with a thickthick layer of whipped cream, the same as Charlie Chaplin would save your life with, and the kid reaches that pie up sky-high overhead, as high as the kid can reach, and brings it down, hard, lightning-fast, slamdunking it hard as the blast from a Polack's shotgun-POW! - right in his old man's kisser.

And despite the miraculous, well-documented healing powers of the Comedic Arts my old man dies taking a big bloody shit in his bed.

No, really, it's funnier than it sounds. Please, don't blame my old man. If you're not laughing at this point, it's my fault. I just didn't tell it right, you know, you mess up a punch line and you can totally
Nada mata uma piada mais rápido do que pedir pro meu coroa explicar ela e, deitado ali naquela cama, ele para de respirar. Zero batimentos cardíacos. Uma puta linha reta.

Daí esse moleque sentado do lado da cama no quarto de hospital, tarde-tarde da noite, ele pega a piada equivalente àquelas raquetes elétricas que os médicos usam pra parar um ataque cardíaco, a zoeira equivalente ao que um Robin Williams paramédico usaria em você numa Emergência pra Palhaços — um tipo de desfibrilador dos Três Patetas - o moleque pega uma torta grande e cremosa recheada de merengue e coberta com uma camada grossagrossa de chantilly, igualzinha a que o Charlie Chaplin usaria pra salvar sua vida, e o moleque levanta a torta lá no alto, o mais alto que ele alcança, e desce ela, com força, na velocidade da luz, ele enterra ela com a força do tiro do polonês - POW! - bem na fuça do coroa.

E independente dos milagrosos e bem documentados poderes de cura das Artes Cômicas, meu coroa morre dando uma bela e sangrenta cagada na cama.

Não, sério, é mais engraçado do que parece. Por favor, não culpa meu coroa. Se você não tá rindo até agora, a culpa é minha. Eu que não contei direito, cê sabe, cê estraga uma frase de efeito e acaba cagando 
botch even the best joke. For example, I went back to the barbershop and told them how he died and how I tried to save him, right up to and including the custard pie and how the hospital had their security goons escort me up to the crazy ward for a little seventy-two-hour observation. And even telling that part, I fucked it up-because those barbershop guys just looked at me. I told them about seeing - and smelling - my old man, dead and smeared all over with blood and shit and whipped cream, all that stink and sugar, and they looked and looked at me, the barbers and the old guys chewing tobacco, and nobody laughed. Standing in that same barbershop all these years later, I say, "Knockknock."

The barbers stop cutting hair. The old goobers stop chewing on their tobacco.

I say, “Knock-knock?” Nobody takes a breath, and it's like I'm standing in a room full of dead men. And I tell them, "Death! DEATH is there! Don't you people never read Emily...Dickerson? You never heard of Jean-Paul...Stuart?" I wiggle my eyebrows and tap the ash from my invisible cigar and say, "Who's there?" I say, "I don't know who's there-I can't even play the violin!" completamente até a melhor piada. Por exemplo, eu voltei na barbearia e contei como ele morreu e como eu tentei salvar ele, contei inclusive do clímax com a torta de merengue e como o hospital fez os babacas da segurança me escoltarem até a ala dos doidos pruma observaçãozinha de setenta e duas horas. E mesmo contando essa parte, eu ferrei com tudo, porque os caras da barbearia ficaram só me encarando. Eu contei que vi - e cheirei - meu coroa, morto e todo borrado de sangue, bosta e chantilly, todo aquele fedor e açúcar e eles me encararam e encararam, os barbeiros e os velhacos mastigando tabaco, e ninguém riu. De pé naquela mesma barbearia, tantos anos depois, eu digo, "Toc-toc".

Os barbeiros param de cortar cabelo. Os velhos melequentos param de mastigar o tabaco.

Eu digo, “Toc-toc?” Ninguém nem respira e é como se eu tivesse parado numa sela cheia de cadáveres. E eu digo pra eles, "A morte! A MORTE chegou! Cês nunca não leram Emily... Dickerson? Nunca ouviram falar do Jean-Paul... Stuart?" Eu mexo as sobrancelhas e sacudo as cinzas do meu cigarro invisível e digo, “Quem é?” Eu digo, "Eu não sei quem é — eu nem toco violino!"

A única coisa que eu sei é que eu tenho uma cabeça cheia de piadas que eu não consigo esquecer — tipo um tumor do tamanho duma 


\begin{tabular}{|c|c|}
\hline $\begin{array}{l}\text { What I do know is I've got a brain filled with jokes I can't ever } \\
\text { forget-like a tumor the size of a grapefruit inside of my skull. And I } \\
\text { know that eventually even dog shit turns white and stops stinking, but } \\
\text { I have this permanent head filled with crap I've been trained my whole } \\
\text { life to think is funny. And for the first time since I was a Little Stooge } \\
\text { standing in that barbershop saying fag and cunt and nigger and saying } \\
\text { kike, I figure out that I wasn't telling a joke-I was the joke. I mean, I } \\
\text { finally Get It. Understand me: A bona fide gold-plated joke is like a } \\
\text { Michelob served ice-cold...with a Mickey Finn...by somebody smiling } \\
\text { so nice you won't never know how bad you've been fucked. And a } \\
\text { punch line is called a "punch line" for a VERY good reason, because } \\
\text { punch lines are a sugarcoated fist with whipped cream hiding the brass } \\
\text { knuckles that socks you right in the kisser, hitting you-POW!- right } \\
\text { in your face and saying, "I am smarter than you”" and "I'm bigger than } \\
\text { you" and "I call the shots, here, Buddy-BOY." And standing in that } \\
\text { same old Saturday morning barbershop, I scream, "Knock-knock!" }\end{array}$ & $\begin{array}{l}\text { laranja no meu crânio. E eu sei que no fim das contas até cocô de } \\
\text { cachorro fica branco e para de feder, mas eu tenho pra sempre essa } \\
\text { cabeça cheia de merda que fui treinado a vida inteira pra achar } \\
\text { engraçado. E pela primeira vez desde que eu era um Pateta mirim de pé } \\
\text { na barbearia dizendo bicha e boceta e negro e judeu, eu percebo que eu } \\
\text { não tava contando a piada - eu era a piada. Quer dizer, eu finalmente } \\
\text { Entendi. Vê se cê me entende: uma piada genuína e banhada a ouro é } \\
\text { que nem uma Budweiser servida bem gelada... com um Boa-noite- } \\
\text { Cinderela... por alguém sorrindo tão simpático que cê nunca vai saber } \\
\text { o quanto foi fodido. E uma frase de efeito chama "frase de efeito" por } \\
\text { um ÓTIMO motivo, porque as frases de efeito têm o mesmo efeito dum } \\
\text { punho coberto de chantilly escondendo o soco inglês que te esmurra } \\
\text { bem no meio da fuça, te batendo - POW! - bem na cara e dizendo } \\
\text { "Eu sou mais esperto que você" e "eu sou maior que você" e "eu dou } \\
\text { as ordens aqui, meu PARÇA". E de pé naquela mesma barbearia dos } \\
\text { sábados de manhã, eu grito, "Toc-toc!" } \\
\text { Eu exijo, "TOC-TOC!" } \\
\text { E finalmente um tiozão velho da barbearia, ele diz num sussurro } \\
\text { baixo e cheio de tabaco, tão suave que mal dá para ouvir, ele pergunta, } \\
\text { "Quem é?" }\end{array}$ \\
\hline
\end{tabular}




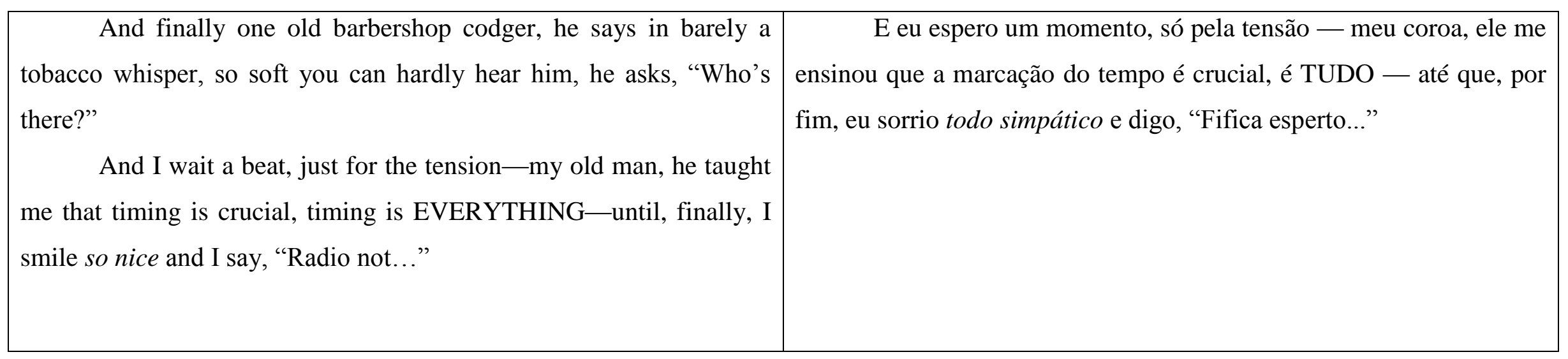




\section{ANEXO B}

"How monkey got married, bought a house, and found happiness in Orlando"

Many years ago, in a world before disillusionment, Monkey walked through the forest, her mouth overflowing with pride. After much effort and sacrifice, she had finished her lengthy schooling. To Raven, Monkey bragged, "Look at me! I have an undergraduate degree in Communications!" To Coyote, she boasted, "I have completed many valuable internships!" In a world before she'd feasted on shame and defeat, Monkey paraded her resume into the Human Resources department of Llewellyn Food Product Marketers, Inc.

Monkey demanded a face-to-face audience with Hamster, who was the Human Resources liaison, and Monkey boldly put forward her resume and bid, "Let me prove myself. Give me a knight's errand."

Thus came Monkey to stand behind a folding table. In grocery stores or department stores, Monkey offered cubes of sausage skewered with toothpicks. Monkey offered dollops of apple pie served in tiny
"Como a macaca se casou, comprou uma casa e encontrou a felicidade em Orlando"

Muitos anos atrás, em um mundo antes da desilusão, uma Macaca andava pela floresta, sua boca transbordando de orgulho. Após muito esforço e sacrifício, ela tinha terminado seu longo período de estudos. Para o Corvo, a Macaca se gabou: - Olhe para mim! Tenho um diploma de graduação em Comunicação! Para o Coiote, exibiu-se: - Eu fiz muitos estágios importantes! Em um mundo antes de se esbaldar em vergonha e derrota, a Macaca desfilava com seu currículo porta adentro do departamento de Recursos Humanos das Indústrias de Alimentos Llewellyn, S.A.

A Macaca exigiu uma entrevista cara-a-cara com o Hamster, que era o representante do Recursos Humanos, e, com ousadia, entregou-lhe seu currículo, pedindo: - Deixe-me provar meu valor. Me dê um desafio.

Foi assim que a Macaca foi parar atrás de uma mesa dobrável. Em mercearias ou lojas de departamento, a Macaca oferecia cubinhos de salsicha furados com palitos de dente. A Macaca oferecia pedaços 
paper cups, or paper napkins cradling sample bites of tofu. Monkey spritzed perfume and offered her own slender neck for lumbering Moose to sniff, and the Moose bought and bought. Blessed was Monkey with charm, and when she smiled at Stag or Panther or Eagle, they smiled in return and sought to buy whatever product Monkey was shilling. She sold cigarettes to Badger, who did not smoke. And Monkey sold beef jerky to Ram, who did not eat meat. So clever was Monkey that she sold hand lotion to Snake, who had no hands!

Back at Llewellyn Foods, Hamster said, "I have an opening in Vegas," and Vegas became but the first in a long chain of triumphs. For now was Monkey part of a team and proved herself to be a team player, and when Hamster bid Monkey relocate - to Philly, to the Twin Cities, to San Fran-Monkey was always eager to flog a new sandwich spread or pimp a new sports drink. And seeing herself a small success, Monkey went again before Hamster at Human Resources and bid, "You have been my advocate, Hamster, and I have served Llewellyn Foods. Test me further." de torta de maçã servidos em potinhos de papel, ou guardanapos com amostras grátis de tofu. A Macaca borrifava perfume e oferecia seu próprio pescoço delgado para convencer o Alce a cheirá-lo, e o Alce comprava e comprava. A Macaca fora abençoada com charme e quando sorria para o Cervo ou o Pantera ou o Águia, eles sorriam de volta e corriam para comprar o que quer que a Macaca estivesse promovendo. Ela vendia cigarros para o Texugo, que não fumava. E a Macaca vendia bifes de charque para o Carneiro, que não comia carne. Tão esperta era a Macaca que vendeu creme de mão para a Cobra, que não tinha mãos! Na sede das Indústrias Llewellyn, o Hamster disse: — Eu tenho uma vaga aberta em Las Vegas, e Vegas se tornou a primeira em uma série de muitas conquistas. Pois agora, a Macaca era parte de um time e provou ser ótima com trabalho em equipe, e quando o Hamster sugeriu sua realocação - para a Filadélfia, para Minneapolis-Saint Paul, para São Francisco - a Macaca estava sempre ansiosa para anunciar um novo patê para sanduíche ou promover um novo isotônico. E, empolgada com esse pequeno sucesso, a Macaca foi novamente até o Hamster no Recursos Humanos e pediu: - Você tem sido meu defensor, Hamster, e eu fiz muito pelas Indústrias Llewellyn. Teste-me mais. 


\begin{tabular}{|c|c|}
\hline $\begin{array}{l}\text { And so arrogant was Monkey that she bade, "Give me your } \\
\text { roblematic cheese." Without so much as a glance at the product in } \\
\text { uestion, Monkey promised to deliver a minimum } 14 \text { percent share in } \\
\text { he highly competitive mid-level imported dairy solids market, and } \\
\text { Monkey further promised that such success would last at least seven } \\
\text { veeks, positioning this new cheese before the forthcoming holiday } \\
\text { ntertainment season. In exchange, Hamster granted that Llewellyn } \\
\text { oods would reward Monkey with the position of Northwest Regional } \\
\text { ind a mate and finally begin a family to balance her career. Most } \\
\text { mportantly, Monkey would never again be compelled to offer her neck }\end{array}$ & $\begin{array}{l}\text { E tão arrogante era a Macaca que apostou: - Dê-me seu queijo } \\
\text { problemático. E sem nem ao menos olhar para o produto em questão, a } \\
\text { Macaca prometeu conseguir uma parcela de no mínimo } 14 \text { por cento no } \\
\text { mercado altamente competitivo de laticínios sólidos importados e } \\
\text { prometeu, ainda, que tal boa ventura duraria pelo menos sete semanas, } \\
\text { colocando o novo queijo como principal opção para a temporada de } \\
\text { entretenimentos festivos que estava por vir. Em troca, o Hamster } \\
\text { garantiu que as Indústrias Llewellyn a recompensariam com o cargo de } \\
\text { Supervisora Regional do Noroeste, para que a Macaca pudesse se } \\
\text { estabelecer em Seattle, comprar um apartamento, encontrar um } \\
\text { parceiro e finalmente iniciar uma família para balancear sua carreira. } \\
\text { Mais importante, a Macaca nunca mais seria persuadida a oferecer seu } \\
\text { pescoço para outro Alce estúpido cheirar. Ou a sorrir vitoriosa para o } \\
\text { Chacal que não parava de rodeá-la no Safeway para devorar seus } \\
\text { cookies. } \\
\text { Nesse tempo distante, antes de conhecer o gosto amargo da } \\
\text { derrota, a Macaca se posicionou atrás de mais uma mesa dobrável, essa }\end{array}$ \\
\hline
\end{tabular}




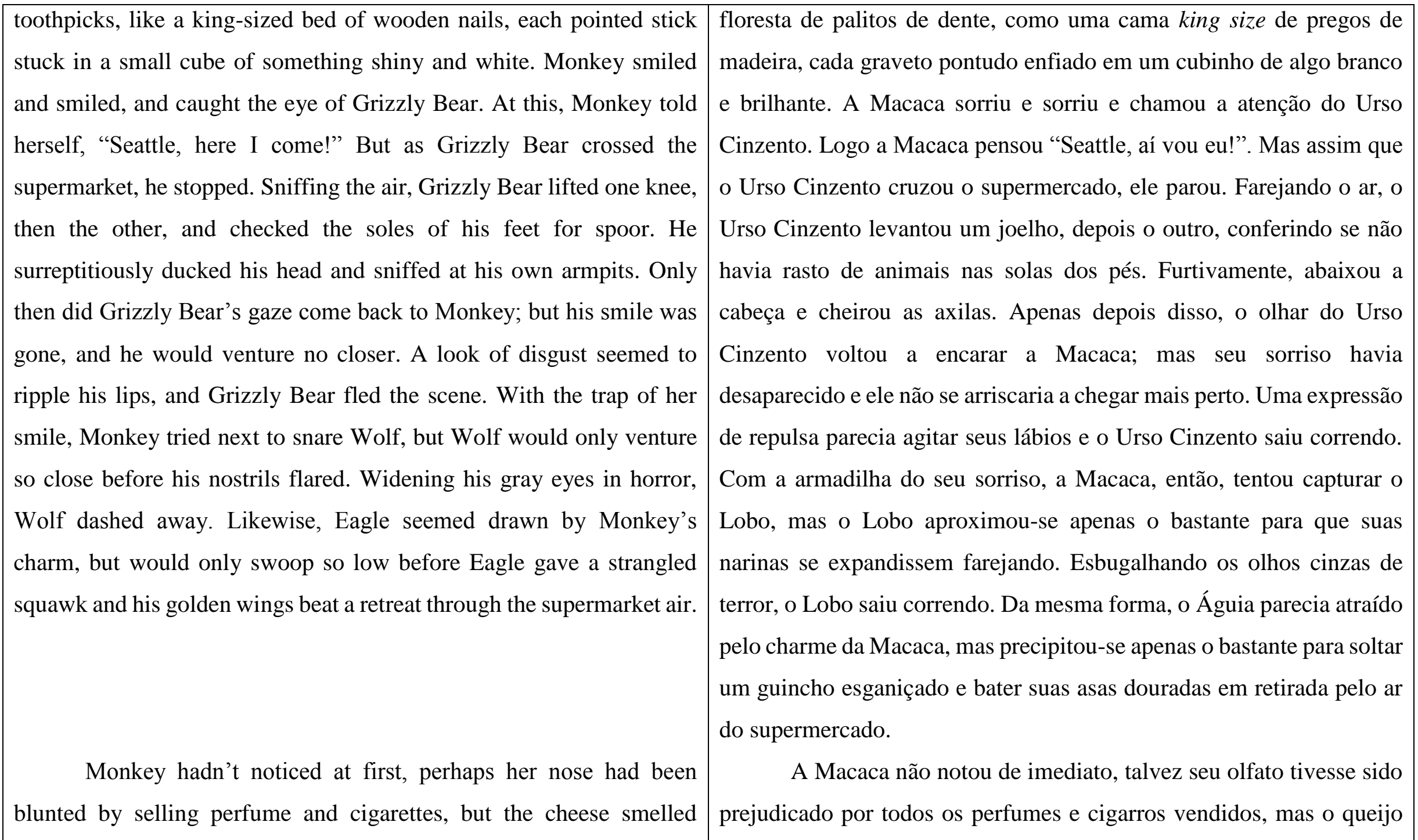




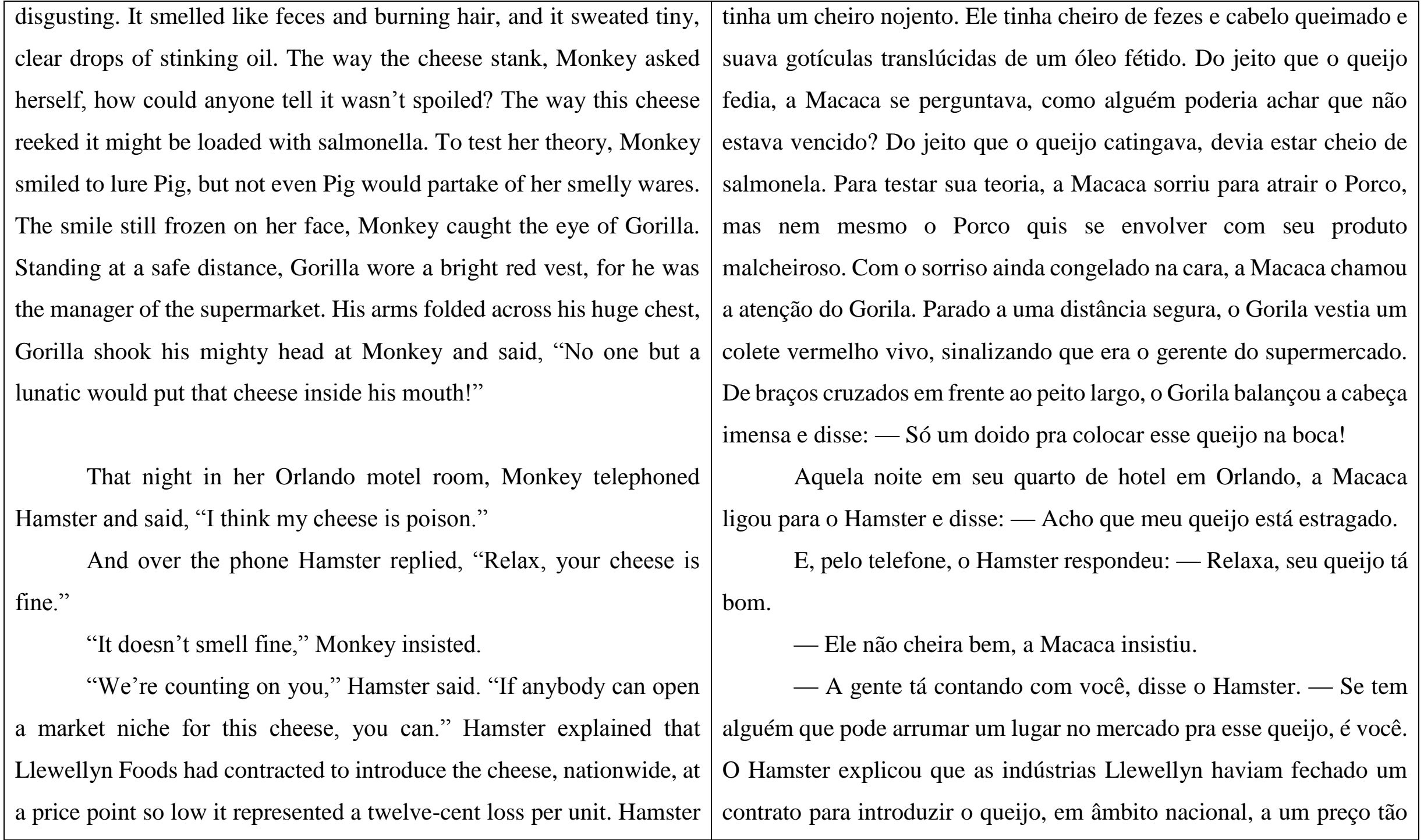


let slip that Monkey's archrival, Coyote, was launching the same cheese in Raleigh-Durham and wasn't reporting any consumer resistance. Over the telephone, Hamster gave forth with a great sigh of exasperation and said that perhaps Coyote would make a better Northwest Regional Supervisor. That maybe Coyote just wanted Seattle more.

After hanging up, Monkey told herself, "I will not lose this promotion to Coyote." She told herself, "Hamster is lying. Coyote couldn't sell nuts to Squirrel." Yet all night Monkey lay awake in bed, listening to Rabbit doing it with Mink in the next motel room, and fretting that, despite her advanced degree in Communications, she'd be stuck below a glass ceiling, getting sniffed by Moose for the rest of her career. For comfort, she wanted to telephone her mother and father, but told herself, "You are grown now, Monkey. Your problems are your own." Instead, she sat in bed, hearing the grunting and rutting through the motel wall and pretending to read The Wapshot Chronicle. As the sun rose on Orlando, Monkey got dressed and put on her makeup, worried that no one would ever love her. She'd never have a real home. baixo que representava um prejuízo de vinte centavos a unidade. $\mathrm{O}$ Hamster deixou vazar que o arqui-inimigo da Macaca, o Coiote, estava promovendo o mesmo queijo na região de Raleigh-Durham e não havia relatado qualquer resistência por parte dos consumidores. Pelo telefone, o Hamster desabafou com um grande suspiro de frustração e disse que talvez o Coiote fosse um candidato melhor para a vaga de Supervisor Regional do Noroeste. Que talvez o Coiote desejasse ir para Seattle com mais ardor.

Após desligar, a Macaca disse a si mesma "não perderei essa promoção para o Coiote". Ela disse "o Hamster está mentindo. O Coiote não venderia uma avelã para um esquilo". Ainda assim, a Macaca passou a noite em claro na cama, ouvindo o Coelho mandar ver com a Doninha no quarto vizinho, preocupada que, mesmo com seu diploma avançado em Comunicação, estaria impedida de crescer profissionalmente por uma barreira invisível, sendo cheirada pelo Alce pelo resto de sua carreira. Para se consolar, ela quis ligar para seus pais, mas disse a si mesma "você já é adulta agora, Macaca. Seus problemas são só seus". Ao invés disso, sentou-se na cama, ouvindo os gemidos e fricções através da parede de hotel e fingindo ler o clássico A crônica dos Wapshot, de John Cheever. Quando o sol nasceu em Orlando, a 


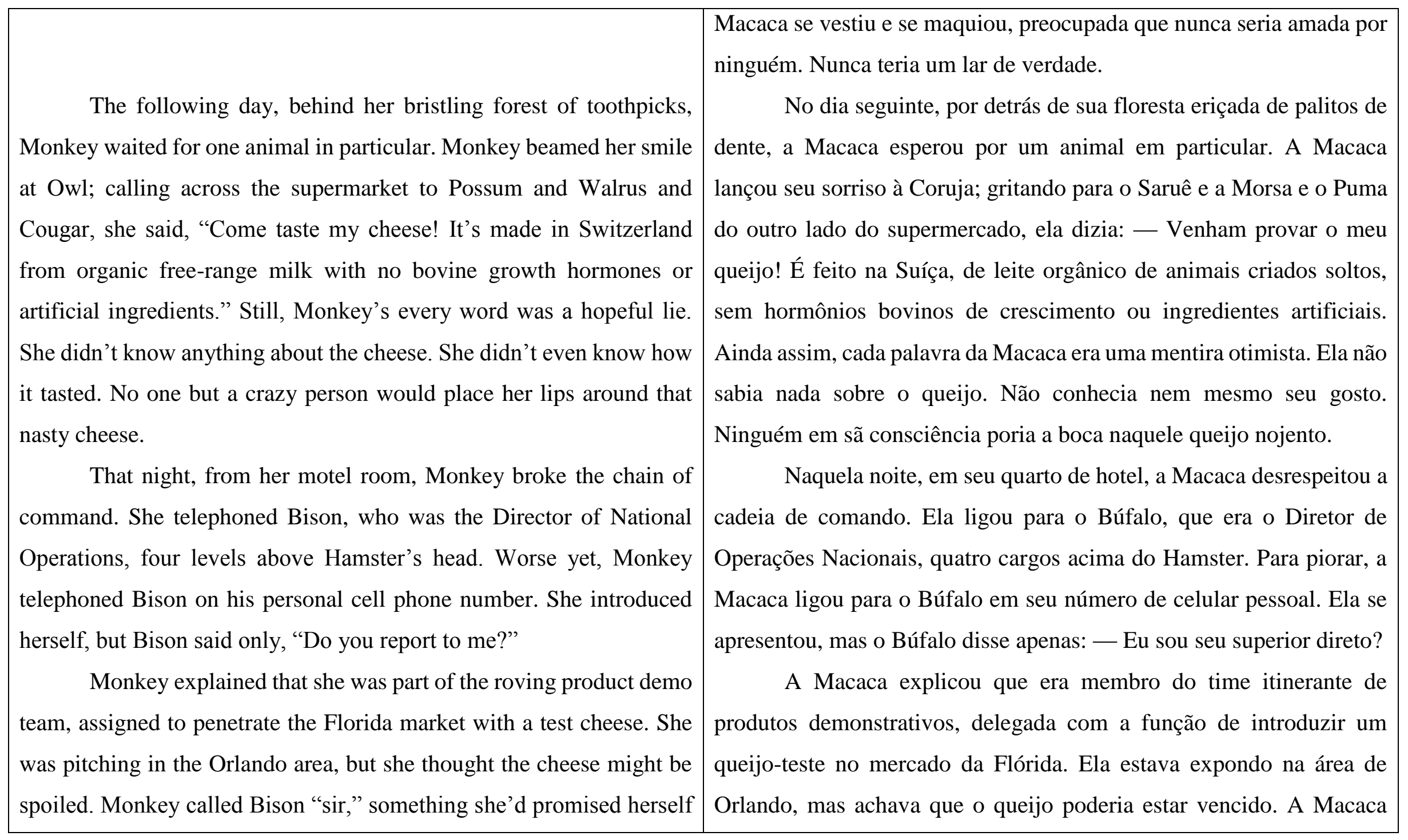




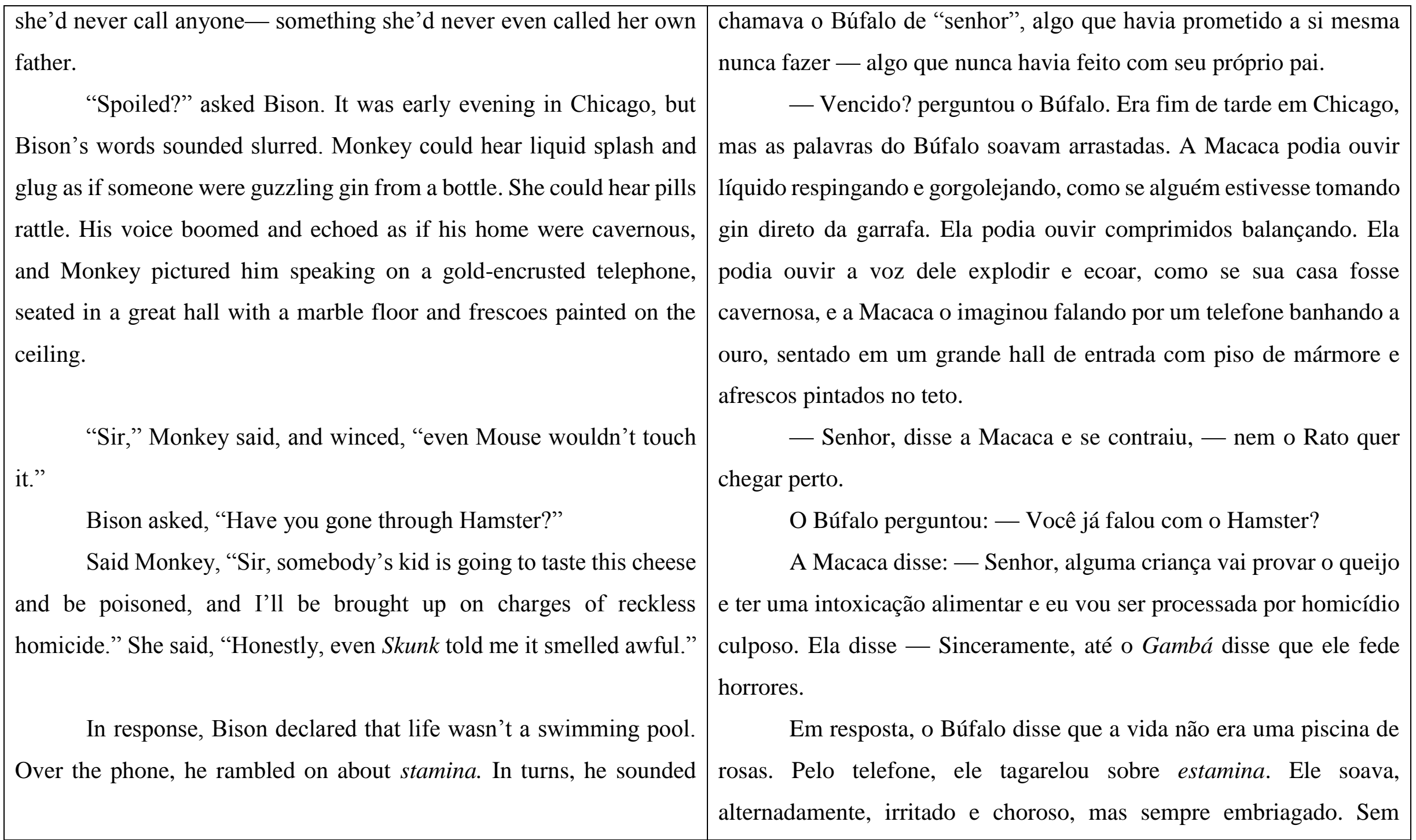




\begin{tabular}{|c|c|}
\hline $\begin{array}{l}\text { angry and weepy, but always soused. Apropos of nothing, he asked he } \\
\text { "What? Are you afraid of getting some shit in your ass?" }\end{array}$ & $\begin{array}{l}\text { motivo algum, ele perguntou: — O quê? Tá com medo de sujar as patas } \\
\text { de merda? }\end{array}$ \\
\hline $\begin{array}{l}\text { So on the third day Monkey was back at her folding table, } \\
\text { behind her stockade of toothpicks, like pikes, like a fence of sharpened } \\
\text { spikes. From beyond this barrier the other animals, the Panther and the } \\
\text { Porcupine, they looked at her with faces of open contempt or deep pity. } \\
\text { An invisible cloud of cheese stink held everyone at bay, and from the } \\
\text { center of everyone's unhappy looks Monkey pleaded and cajoled for } \\
\text { someone brave enough to try this new, marvelous product. Monkey } \\
\text { railed that they were cowards. She dared them. She bribed them with } \\
\text { double-their-money-back guarantees if they sampled the cheese and } \\
\text { didn't love it. She coaxed them, saying, "Who's going to be first in line } \\
\text { to discover sheer joy?" }\end{array}$ & $\begin{array}{l}\text { Então no terceiro dia, lá estava a Macaca, de volta à mesa } \\
\text { dobrável, por detrás da barricada de palitos de dente, como um muro, } \\
\text { como uma cerca de espetos afiados. Do outro lado dessa barreira, os } \\
\text { demais animais, a Pantera e o Porco-espinho, olhavam para ela com } \\
\text { expressões de claro desdém ou profunda pena. Uma nuvem invisível de } \\
\text { fedor de queijo matinha todos afastados, e do centro dos olhares } \\
\text { infelizes de todos, a Macaca implorava e clamava, bajuladora, por } \\
\text { alguém corajoso o bastante para provar esse novo, maravilhoso } \\
\text { produto. A Macaca os chamava de covardes. Ela os desafiava. Ela os } \\
\text { subornava com garantias de "o dobro do seu dinheiro de volta" se } \\
\text { provassem o queijo e não amassem. Ela os seduzia, dizendo: - Quem } \\
\text { vai ser o primeiro da fila a descobrir a mais pura felicidade? }\end{array}$ \\
\hline $\begin{array}{l}\text { From a safe distance Raven shouted, "You'd have to be suicidal } \\
\text { to bite down on that!" Other animals nodded and snickered. Gorilla } \\
\text { watched, impatiently tapping the toes of one foot, weaving his fingers } \\
\text { together and cracking his huge knuckles, ready to throw Monkey out } \\
\text { onto the sidewalk. }\end{array}$ & $\begin{array}{l}\text { De uma distância segura, o Corvo gritou: — Alguém tem que } \\
\text { ser suicida pra morder isso aí! Outros animais aquiesceram e deram } \\
\text { risadinhas. O Gorila assistiu, batendo impaciente os dedos do pé, } \\
\text { enlaçando os dedos das mãos e estalando as juntas enormes, pronto para } \\
\text { jogar a Macaca na calçada. }\end{array}$ \\
\hline
\end{tabular}




\begin{tabular}{|c|c|}
\hline $\begin{array}{l}\text { "If your stuff is so great, lady," challenged Ferret, "why don't } \\
\text { you eat it?" }\end{array}$ & $\begin{array}{l}\text { - Se tua parada é tão boa, moça, desafiou o Furão, - por que } \\
\text { você não come? }\end{array}$ \\
\hline Monkey looked at the table spread with tiny cubes of white & A Macaca olhou para a mesa cheia de minúsculos cubos de \\
\hline poison. She told herself, "Everyone thinks this terrible smell is me." & veneno branco. Ela disse a si mesma "Todos pensam que o cheiro ruim \\
\hline Her arrogance was gone. Monkey hadn't slept in two days, and her & vem de mim". Sua arrogância se esvaiu. A Macaca não dormia havia \\
\hline pride was gone. She told herself, "I'd rather be dead than stand here for & dois dias, e seu orgulho se fora. Ela disse a si mesma "Prefiro morrer a \\
\hline another moment with everyone despising me or feeling sorry for me." & ficar aqui mais um minuto com todos me odiando ou sentindo pena de \\
\hline She imagined herself dying in terrible pain on the concrete floor of this & mim". Ela se imaginou morrendo uma morte horrível e dolorosa no piso \\
\hline Orlando supermarket. She imagined the charges of wrongful death, and & de concreto desse supermercado em Orlando. Ela imaginou as \\
\hline her parents winning a landmark civil settlement against Llewellyn & acusações de morte acidental e seus pais ganhando um acordo civil \\
\hline Foods. Monkey pinched a toothpick between two fingers and held it up & histórico contra as Indústrias Llewellyn. A Macaca pegou um palito de \\
\hline between herself and the crowd. She held the cube of cheese high, like & dente com dois dedos e segurou no alto, entre ela e a multidão. Ela \\
\hline a torch. She imagined her own funeral and saw herself dead in a casket & levantou o cubo de queijo como uma tocha. Ela imaginou seu próprio \\
\hline with these same fingers folded across her cold chest. Monkey saw her & funeral e se viu morta em um caixão com esses mesmos dedos cruzados \\
\hline name and today's date chiseled on a tombstone. This cheese smelled & ao redor de seu peito frio. A Macaca viu seu nome e a data de hoje \\
\hline the way death smelled. It smelled the way she would soon smell. & $\begin{array}{l}\text { entalhadas em uma lápide. Esse queijo cheirava à morte. Ele tinha o } \\
\text { cheiro que ela logo mais também teria. }\end{array}$ \\
\hline "Give me a knight's errand," Monkey told herself, holding the & — Dê-me um desafio, a Macaca disse a si mesma, segurando o \\
\hline cheese on-high. "Test $n$ & lá no alto. — Teste-me mais. \\
\hline
\end{tabular}


The crowd watched, dumbfounded. Slack jawed. Turkey wept quietly.

Monkey closed her eyes and brought the cheese to her mouth. Her lips plucked it from the toothpick, and she began to chew. Her eyes still closed, she heard Gorilla shout, his voice high-pitched with panic, "Someone call 9-1-1!"

Monkey ate the cheese yet she did not die. She ate and ate it. She never wanted to swallow, only to chew it, to grind the cheese between her teeth forever and to always savor it. She wanted to live forever so that she could eat nothing else. Worse than killing her, the cheese tasted-incredible. What had been the worst smell in the world, it became the best, and even after Monkey had gulped it down she sucked the wooden toothpick for the last hint of flavor. The cheese was inside her; it was part of her, and she loved it.

Smiling, Monkey opened her eyes to find everyone staring, their faces knotted in horror. Their eyes bulged as if they'd caught her eating her own scat. As repugnant as she'd seemed before, now she seemed even more repulsive to them, but Monkey didn't care. With all the animals watching she ate another cube of cheese, and another. She
A multidão assistia, embasbacada. De queixo caído. O Peru chorava em silêncio.

A Macaca fechou os olhos e trouxe o queijo até a boca. Seus lábios o arrancaram do palito e ela começou a mastigar. Com os olhos ainda fechados, ela ouviu o Gorila gritar, sua voz esganiçada de pânico: - Alguém liga pra emergência!

A Macaca comeu o queijo e não morreu. Ela comeu e comeu. Ela nunca queria engolir, apenas mastigar, triturar o queijo com os dentes eternamente e para sempre saboreá-lo. Ela queria viver até o fim dos tempos para poder comer apenas aquilo. Pior do que matá-la, o queijo tinha um gosto - incrível. O que antes era o pior cheiro do mundo, tornou-se o melhor, e mesmo depois de engoli-lo, ela chupou o palitinho em busca do que havia sobrado ali de sabor. O queijo estava dentro dela; era parte dela e ela o amava.

Sorrindo, a Macaca abriu os olhos e encontrou todos a encarando, seus rostos contorcidos de horror. Os olhos esbugalhados, como se a tivessem flagrado comendo sua própria merda. Repugnante que parecia antes, agora ela era ainda mais asquerosa para eles, mas a Macaca não se importava. Com todos os animais assistindo, ela comeu 


\begin{tabular}{|c|c|}
\hline $\begin{array}{l}\text { wanted to be filled with this glorious taste and smell until her belly } \\
\text { ached. }\end{array}$ & $\begin{array}{l}\text { outro cubo de queijo, e mais outro. Ela queria ser preenchida por esse } \\
\text { gosto e cheiro gloriosos até sua barriga doer. }\end{array}$ \\
\hline That night in her motel room the telephone rang. It was Hamster & Naquela noite, em seu quarto de hotel, o telefone tocou. Era o \\
\hline $\begin{array}{l}\text { calling. Hamster said, "Hold on while I get Bison on the other line." } \\
\text { Monkey waited, and after a few clicks a voice said, "Bison, here." }\end{array}$ & $\begin{array}{l}\text { Hamster ligando. O Hamster disse: - Espera na linha enquanto } \\
\text { conecto o Búfalo. A Macaca aguardou e, após alguns cliques, uma voz } \\
\text { disse: - Aqui é o Búfalo. }\end{array}$ \\
\hline Bison said, "On the advice of Legal, we're pulling the cheese & O Búfalo disse: - O Jurídico aconselhou e vamos tirar o queijo \\
\hline from outlets." He said, "We can't risk the lia & de circulação. Ele disse: — Não podemos correr o risco. \\
\hline $\begin{array}{l}\text { Monkey knew her job hung in the balance. She told herself to } \\
\text { stay quiet and just let events run their course, but instead she said, } \\
\text { "Wait." }\end{array}$ & $\begin{array}{l}\text { A Macaca sabia que seu emprego estava por um fio. Ela disse a } \\
\text { si mesma para ficar quieta e deixar as coisas acontecerem, mas o invés } \\
\text { disso ela disse: - Esperem. }\end{array}$ \\
\hline Hamster said, "Nobody’s blaming you." & O Hamster disse: — Ninguém tá culpando você. \\
\hline $\begin{array}{l}\text { Monkey said, "I was wrong." She said, "You can fire me, but } \\
\text { that cheese is delicious." She said, "Please." She said, "Sir." }\end{array}$ & $\begin{array}{l}\text { Macaca disse: — Eu estava errada. Ela disse: — Pode me } \\
\text { demitir, mas o queijo é delicioso. Ela disse: — Por favor. Ela disse: } \\
\text { Senhor. }\end{array}$ \\
\hline $\begin{array}{l}\text { With a shrug in his voice, Bison said, "This matter is out of our } \\
\text { hands." Over the phone he said, "Tomorrow, you dispose of your stock } \\
\text { samples." }\end{array}$ & $\begin{array}{l}\text { Em um tom de quem não se importa, o Búfalo disse: — Isso tá } \\
\text { fora do nosso alcance. Pelo telefone, ele disse: — Amanhã você se livra } \\
\text { do seu estoque de amostras. }\end{array}$ \\
\hline “Ask Coyote,” Monkey pleaded. “Coyote's pitching it." & $\begin{array}{l}\text { — Pergunte ao Coiote, a Macaca insistiu. — O Coiote está } \\
\text { promovendo ele também. }\end{array}$ \\
\hline
\end{tabular}




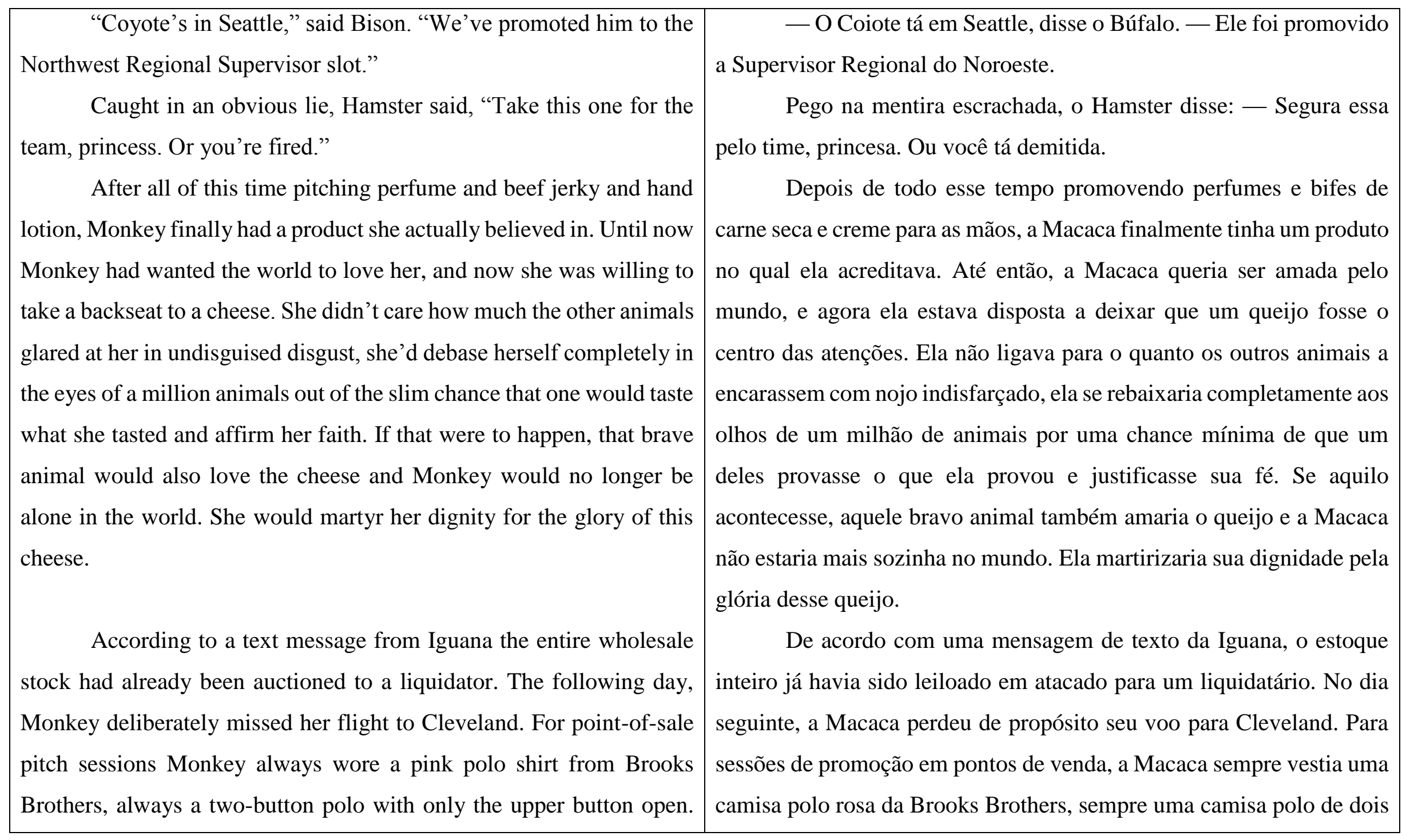


Pink read as gamine, sporty, preppy, and Monkey never popped the collar. However, with everything at stake today she pulled out her heavy artillery: a chemise top with floss shoulder straps and a hem so short it fluttered above a wide margin of her exposed stomach. She wedged her breasts into a padded bra. To put this cheese across, Monkey would play the temple whore and pimp herself worse than Llewellyn Foods had ever dared. Brazenly, she took her folding table and toothpicks and white cubes of mouthwatering, soul-filling nirvana and went back to the Orlando supermarket. Behind her altar of samples, Monkey was a zealot. A fanatic. She was an evangelical, railing and haranguing everyone within the crowded market. She was a lunatic in their eyes-someone who would eat this cheese was capable of anything - and this seemed to protect her for the moment. If she could only communicate her passion and be understood by one other animal, that would be enough.

"Satisfaction is here for the taking," said Monkey. "Absolute bliss can be yours for free!" Only the smell of the cheese kept Duck and Ox from seizing her, from grabbing Monkey and tossing her bodily from the building, but Grizzly Bear shouted obscenities at her through cupped paws, and Parrot pelted her with stinging pennies. botões com o botão de cima aberto. Rosa passava a imagem de patricinha brincalhona, meio ingênua e meio maliciosa, e a Macaca nunca abria toda a gola. Entretanto, com tudo em jogo, hoje ela tirou do armário a artilharia pesada: uma camisete com alças fininhas e uma barra tão curta que deixava uma grande parte de sua barriga exposta. Ela espremeu os seios em sutiãs de enchimento. Para vender esse queijo, a Macaca interpretaria a puta abençoada e seria mais cafetina de seu corpo do que as Indústrias Llewellyn jamais ousaram ser. Insolente, ela pegou a mesa dobrável e os palitos de dente e cubinhos brancos de nirvana suculento e iluminado, e voltou ao supermercado de Orlando. Por detrás do altar de amostras, a Macaca era uma devota fanática. Aos olhos dos outros, ela era uma doida varrida - uma pessoa que comeria esse queijo era capaz de qualquer coisa - e isso parecia protegê-la por enquanto. Se ao menos ela pudesse expressar sua paixão e ser compreendida por um outro animal, já seria o bastante.

— O prazer está à sua disposição, dizia a Macaca. — A mais plena felicidade pode ser sua de graça! Apenas o cheiro do queijo impediu o Pato e o Boi de a agarrarem, de a pegarem a força e a jogarem para fora do prédio, mas o Urso Cinzento gritava obscenidades para ela 


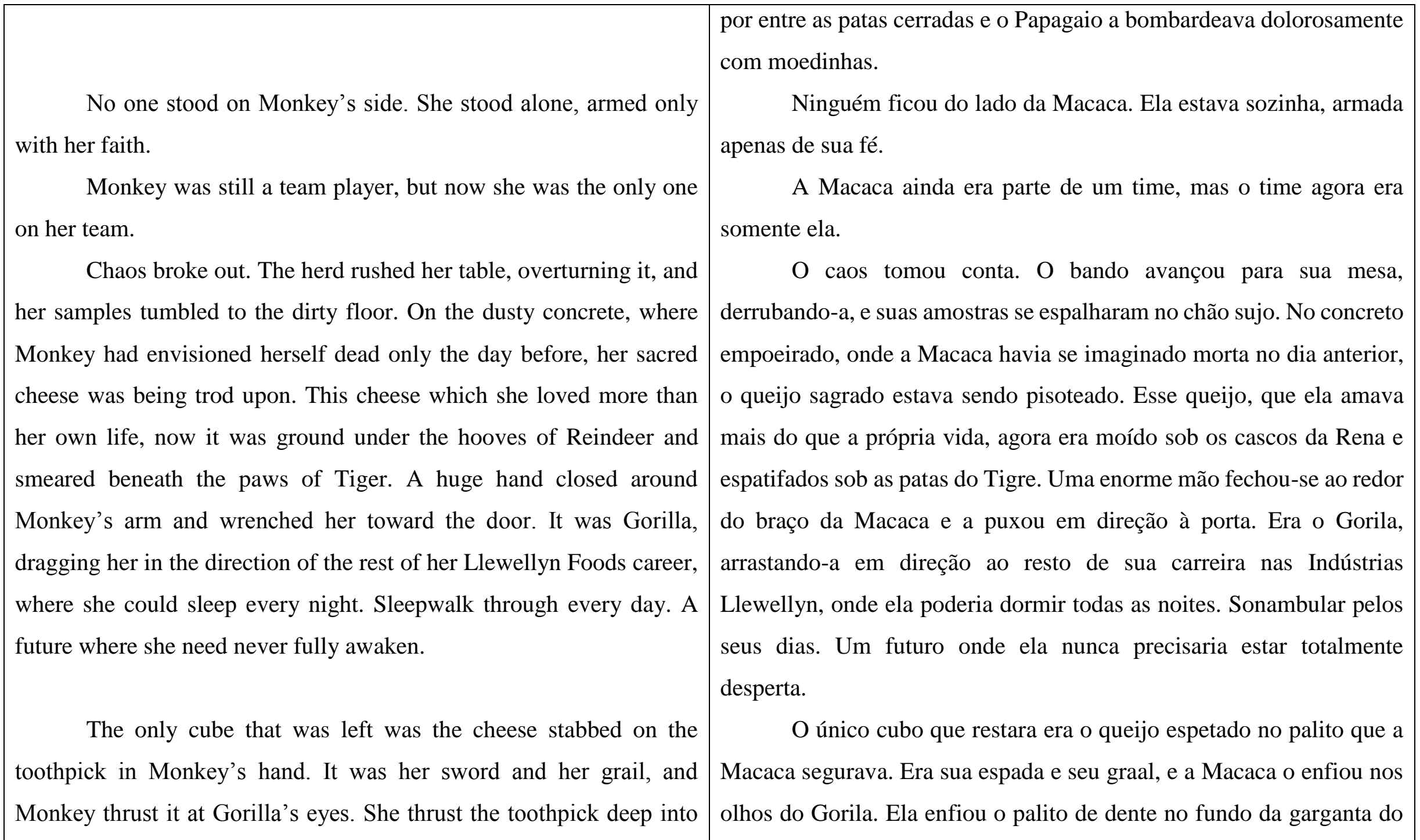


the back of Gorilla's mouth, and he choked and gagged and spat out the cheese, but Monkey caught the wet, white cube as it fell. She lifted the slimy cheese cradled in the palm of one hand and slapped it between Gorilla's lips. With the stampede of animals lifting them both and carrying them toward the exit, Monkey kept her hand muzzled across Gorilla's mouth, her eyes meeting his eyes until Gorilla chewed and swallowed. Until she felt the huge muscles of his struggling arms relax and go slack with understanding.
Gorila e ele engasgou e sufocou e cuspiu o queijo, mas a Macaca pegou o cubo branco e molhado no ar. Ela levantou o queijo pegajoso, aninhado na palma da mão, e o meteu entre os lábios do Gorila. Com a debandada de animais levantando os dois e os carregando em direção à saída, a Macaca manteve sua mão cerrada por sobre a boca do Gorila, seus olhos encontrando os dele até que o Gorila mastigou e engoliu. Até que sentiu os enormes músculos de seus braços inquietos relaxarem e ficarem imóveis em compreensão. 


\section{ANEXO C}

\begin{tabular}{|c|c|}
\hline Zombie & Zumbi \\
\hline $\begin{array}{l}\text { It was Griffin Wilson who proposed the Theory of De- } \\
\text { evolution. He sat two rows behind me in Organic Chem, the very } \\
\text { definition of an evil genius. He was the first to take the Great Leap } \\
\text { Backward. }\end{array}$ & $\begin{array}{l}\text { Foi o Griffin Wilson que propôs a Teoria da Involução. Ele } \\
\text { sentava duas fileiras atrás de mim em Química Orgânica, a verdadeira } \\
\text { definição de gênio do mal. Ele foi o primeiro a dar o Grande Passo pra } \\
\text { Trás. }\end{array}$ \\
\hline Everybody knows because Tricia Gedding was in the nurse's & Todo mundo sabe porque a Tricia Gedding tava na enfermaria \\
\hline office with him. She was in the other cot, behind a paper curtain, faking & com ele. Ela tava na outra maca, atrás da cortina de papel, fingindo que \\
\hline her period to get out of a pop quiz in Perspectives on Eastern Civ. She & tava menstruada para fugir de um teste surpresa de Perspectivas sobre \\
\hline said she heard the loud beep! but didn't think a & a Civilização Oriental. Ela disse que ouviu um beep! bem alto, mas não \\
\hline Tricia Gedding and the school nurse found him on his own cot, they & achou que fosse nada de mais. Quando a Tricia Gedding e a enfermeira \\
\hline thought Griffin Wilson was the resuscitation doll everybody uses to & da escola encontraram ele na maca, pensaram que o Griffin Wilson \\
\hline practice $\mathrm{CPR}$. He was hardly breathing, barely & fosse o boneco de reanimação que todo mundo usava para praticar RCP. \\
\hline thought it was a joke because his wallet was still clenched between his & Ele mal respirava, não movia um dedo sequer. Elas pensaram que fosse \\
\hline teeth and he still had the electrical wires pasted to either side of his & uma brincadeira, porque a carteira dele ainda tava presa entre os dentes \\
\hline forehead. & e os fios elétricos ainda tavam grudados em cada lado da testa. \\
\hline His hands were still holding a dictionary-size box, still & As mãos dele ainda seguravam uma caixa do tamanho dum \\
\hline paralyzed, pressing a big, red button. Everyone's seen this box so often & dicionário, paralisadas, apertando um grande botão vermelho. Todo \\
\hline
\end{tabular}




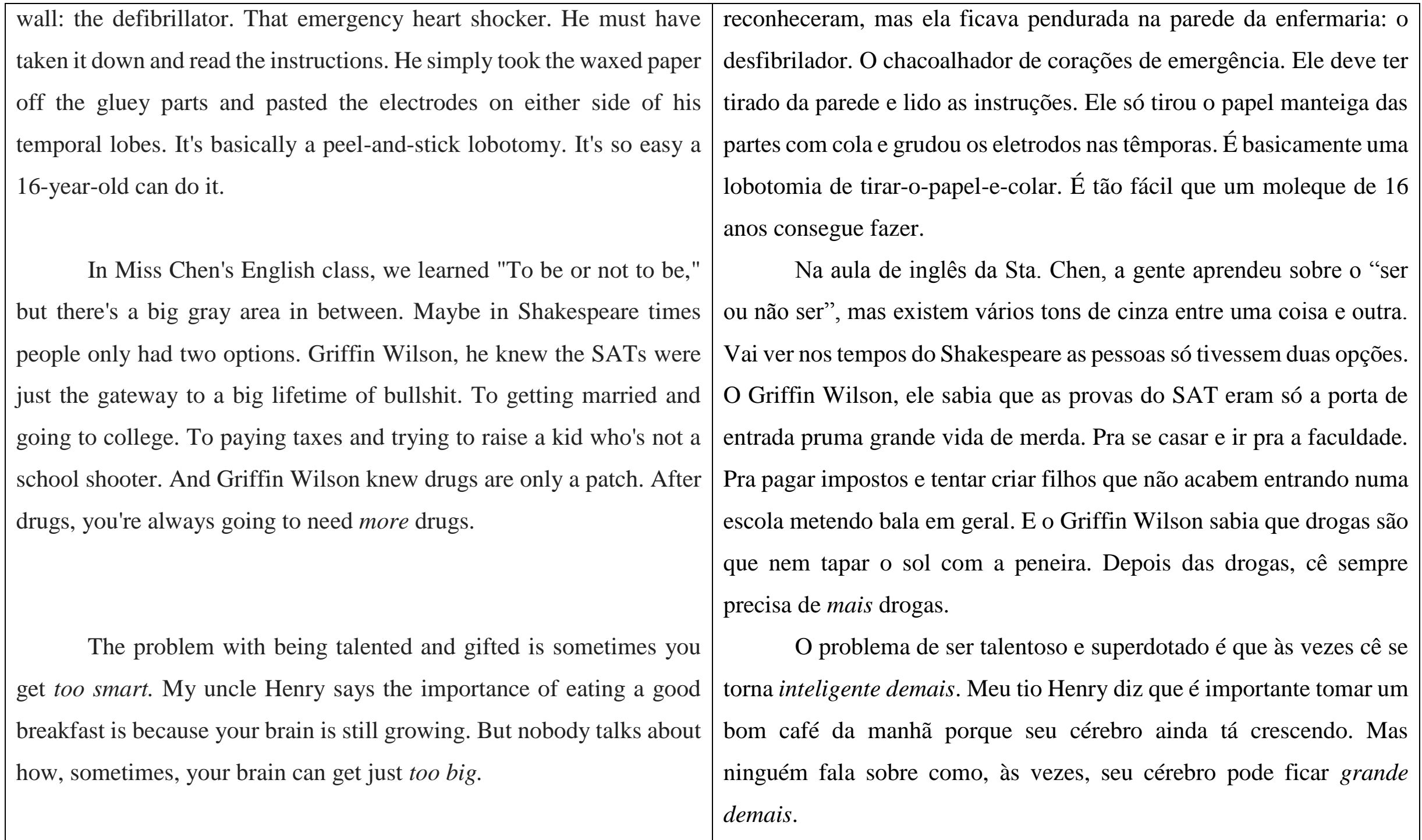


We're basically big animals, evolved to break open shells and eat raw oysters, but now we're expected to keep track of all 300 Kardashian sisters and 800 Baldwin brothers. Seriously, at the rate they reproduce the Kardashians and the Baldwins are going to wipe out al other species of humans. The rest of us, you and me, we're just evolutionary dead ends waiting to wink out.

You could ask Griffin Wilson anything. Ask him who signed the Treaty of Ghent. He'd be like that cartoon magician on TV who says, "Watch me pull a rabbit out of my head." Abracadabra, and he'd know the answer. In Organic Chem, he could talk string theory until he was anoxic, but what he really wanted to be was happy. Not just not sad, he wanted to be happy the way a dog is happy. Not constantly jerked this way and that by flaming instant messages and changes in the federal tax code. He didn't want to die either. He wanted to be-and not to be-but at the same time. That's what a pioneering genius he was.
Resumindo, nós somos grandes animais, evoluídos o bastante pra quebrar conchas e comer ostras cruas, mas agora esperam que a gente acompanhe os passos de todas as 300 irmãs Kardashian e 800 irmãos Baldwin. Sério mesmo, no ritmo em que essa galera se reproduz, as Kardashians e os Baldwins vão eliminar todas as outras espécies humanas. O resto de nós, você e eu, somos apenas becos sem saída evolucionários esperando o momento de desaparecer.

Cê podia perguntar qualquer coisa pro Griffin Wilson. Pergunta quem assinou o Tratado de Gante. Ele ia fazer que nem aquele mágico do desenho que diz "Olha só como tiro um coelho da cebeça". Abracadabra e ele sabia a resposta. Em Química Orgânica, ele podia falar da teoria das cordas até perder o fôlego, só que o que ele realmente queria era ser feliz. Não só não estar triste, ele queria ser feliz como um cachorro é feliz. Não ser puxado o tempo todo prum lado ou pro outro por malditas mensagens de texto e mudanças em códigos fiscais federais. Ele não queria morrer também. Ele queria ser - e não ser mas ao mesmo tempo. Esse era o tamanho da genialidade pioneira dele. 


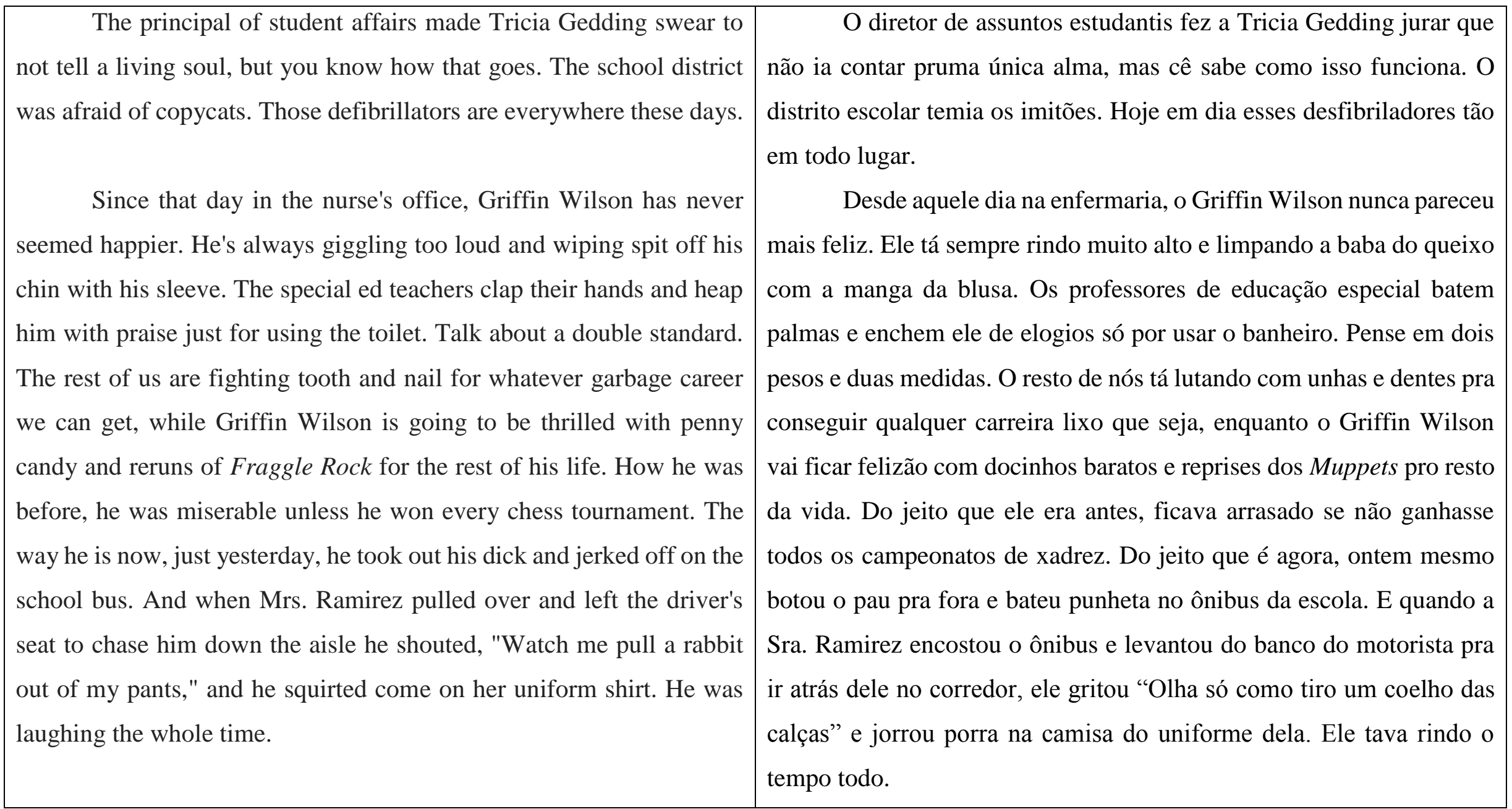




\begin{tabular}{|c|c|}
\hline $\begin{array}{l}\text { life of the party. } \\
\text { The voltage even cleared up his acne. } \\
\text { It's hard to argue with results like that. } \\
\text { It wasn't a week after he'd turned zombie that Tricia Gedding } \\
\text { went to the gym where she does Zumba and got the defibrillator off the } \\
\text { wall in the girls' locker room. After her self-administered peel-and-stick } \\
\text { procedure in a bathroom stall, she doesn't care where she gets her } \\
\text { period. Her best friend, Brie Phillips, got to the defibrillator they keep } \\
\text { next to the bathrooms at the Home Depot, and now she walks down the } \\
\text { street, rain or shine, with no pants on. We're not talking about the scum } \\
\text { of the school. We're talking about class president and head cheerleader. } \\
\text { The best and the brightest. Everybody who played first string on all the } \\
\text { sports teams. It took every defibrillator between here and Canada, but } \\
\text { since then, when they play football nobody plays by the rules. And even } \\
\text { when they get skunked, they're always grinning and slapping high fives. }\end{array}$ & $\begin{array}{l}\text { Lobotomia ou não, ele ainda sabe o que é uma frase de efeito. } \\
\text { Ao invés de ser só mais um cara obcecado por notas, ele agora é o } \\
\text { centro das atenções. } \\
\text { A voltagem acabou até com a acne dele. } \\
\text { É difícil argumentar contra resultados como esses. } \\
\text { Menos de uma semana depois dele virar zumbi, a Tricia } \\
\text { Gedding foi pra academia de zumba dela e tirou o desfibrilador da } \\
\text { parede do vestiário feminino. Depois de administrar nela mesma o } \\
\text { procedimento de tirar-o-papel-e-colar num cubículo do banheiro, ela } \\
\text { não liga mais pra onde ela tá quando a menstruação desce. A melhor } \\
\text { amiga dela, a Brie Phillips, usou o desfibrilador que deixam perto dos } \\
\text { banheiros na Home Depot e agora anda pelas ruas sem as calças, faça } \\
\text { chuva ou faça sol. E não tamo falando aqui da escória do colégio. Tamo } \\
\text { falando do presidente de sala e da capitã das líderes de torcida. Os } \\
\text { melhores e mais brilhantes. Todo mundo que jogava na primeira } \\
\text { posição nos times de todos os esportes. Tiveram que usar de todos os } \\
\text { desfibriladores daqui até o Canadá, mas, desde então, quando eles } \\
\text { jogam futebol, ninguém segue mais as regras. E mesmo quando levam } \\
\text { esporro tão sempre sorrindo e batendo high fives. }\end{array}$ \\
\hline
\end{tabular}




\begin{tabular}{|c|c|}
\hline They continue to be young and hot, but they no longer worry & Eles continuam sendo jovens e gostosos, mas não se preocupam \\
\hline about the day when they won't be. & mais com o dia em que vão deixar de ser. \\
\hline It's suicide, but it's not. The newspaper won't report the actual & É suicídio, mas não é. O jornal não relata os números exatos. Os \\
\hline numbers. Newspapers flatter themselves. Anymore, Tricia Gedding's & jornais se acham demais. Hoje em dia, a página do Facebook da Tricia \\
\hline Facebook page has a larger readership than our daily paper. Mass & Gedding tem mais leitores do que nosso jornal diário. Comunicação em \\
\hline media, my foot. They cover the front page with unemployment and war, & massa uma ova. Eles enchem a primeira página de desemprego e guerra \\
\hline and they don't think that has a negative effect? My uncle Henr & e não acham que aquilo tem um efeito negativo? Meu tio Henry leu pra \\
\hline me an article about a proposed change in state law. Officials want a 10- & mim um artigo sobre uma proposta de mudança na lei estadual. As \\
\hline day waiting period on the sale of all heart defibrillators. They're talking & autoridades públicas querem um prazo de espera de dez dias na venda \\
\hline about mandatory background checks and mental health screenings. But & de todos os desfibriladores cardíacos. Tão falando de obrigar a \\
\hline it's not the law, not yet. & $\begin{array}{l}\text { verificação de antecedentes e testes de saúde mental. Mas não é lei, } \\
\text { ainda não. }\end{array}$ \\
\hline My uncle Henry looks up from the newst & Meu tio Henry levanta os olhos do artigo de jornal e olha pra \\
\hline me across breakfast. He levels me this stern look and asks, "If all your & mim, do outro lado da mesa de café da manhã. Ele me avalia com um \\
\hline friends jumped off a cliff, would you?" & $\begin{array}{l}\text { olhar severo e pergunta, "Se todos os seus amigos pulassem dum } \\
\text { penhasco, cê pularia?" }\end{array}$ \\
\hline My uncle's what I ha & Meu tio é o que eu tenho no lugar dum pai e mãe. Ele não \\
\hline acknowledge it, but there's a good life over the edge of that cliff. There's & admite, mas tem uma vida boa esperando a gente além da borda daquele \\
\hline a lifetime supply of handicapped parking permits. Uncle Henry doesn't & penhasco. Um estoque vitalício de autorizações pra vagas de deficiente. \\
\hline understand that : & não entende que todos \\
\hline
\end{tabular}


They may be "differently abled," but my friends are still hooking up. More than ever, these days. They have smoking-hot bodies and the brains of infants. They have the best of both worlds. LeQuisha Jefferson stuck her tongue inside Hannah Finermann during Beginning Carpentry Arts, made her squeal and squirm right there, leaned up against the drill press. And Laura Lynn Marshall? She sucked off Frank Randall in the back of International Cuisine Lab with everybody watching. All their falafels got scorched, and nobody made a federal case out of it.

After pushing the red defibrillator button, yeah, a person suffers some consequences, but he doesn't know he's suffering. Once he undergoes a push-button lobotomy a kid can get away with murder.

During study hall, I asked Boris Declan if it hurt. He was sitting there in the lunchroom with the red burn marks still fresh on either side of his forehead. He had his pants down around his knees. I asked if the shock was painful, and he didn't answer, not right away. He just took his fingers out of his ass and sniffed them, thoughtfully. He was last year's junior prom king.
Eles podem ser "portadores de necessidades especiais", mas meus amigos ainda tão se dando bem. Mais do que nunca, hoje em dia. Eles têm corpos de parar o trânsito e cérebros de recém-nascidos. Eles têm o melhor dos dois mundos. A LeQuisha Jefferson enfiou a língua na Hanna Finermann no meio da aula de Carpintaria Artística para Iniciantes e fez ela gemer e se contorcer bem ali, escorada na bancada da furadeira. E a Laura Lynn Marshall? Ela chupou o Frank Randall no fundo do Laboratório de Cozinha Internacional com todo mundo olhando. Todos os falafels dela pegaram fogo e ninguém fez disso um caso de polícia.

Depois de apertar o botão vermelho do desfibrilador, sim, a pessoa sofre algumas consequências, mas ela não sabe que tá sofrendo. Uma vez que passe pela lobotomia-de-um-botão-só, o cara pode matar alguém e sair impune.

Durante o plantão de estudos, pergunto pro Boris Declan se doeu. Ele tava sentado lá no refeitório, com as queimaduras vermelhas ainda recentes nas têmporas. Ele tava com as calças abaixadas até os joelhos. Perguntei se o choque era doloroso e ele não respondeu, não imediatamente. Ele apenas tirou os dedos da bunda e cheirou, pensativo. Ano passado, ele foi o rei do baile do segundo ano. 


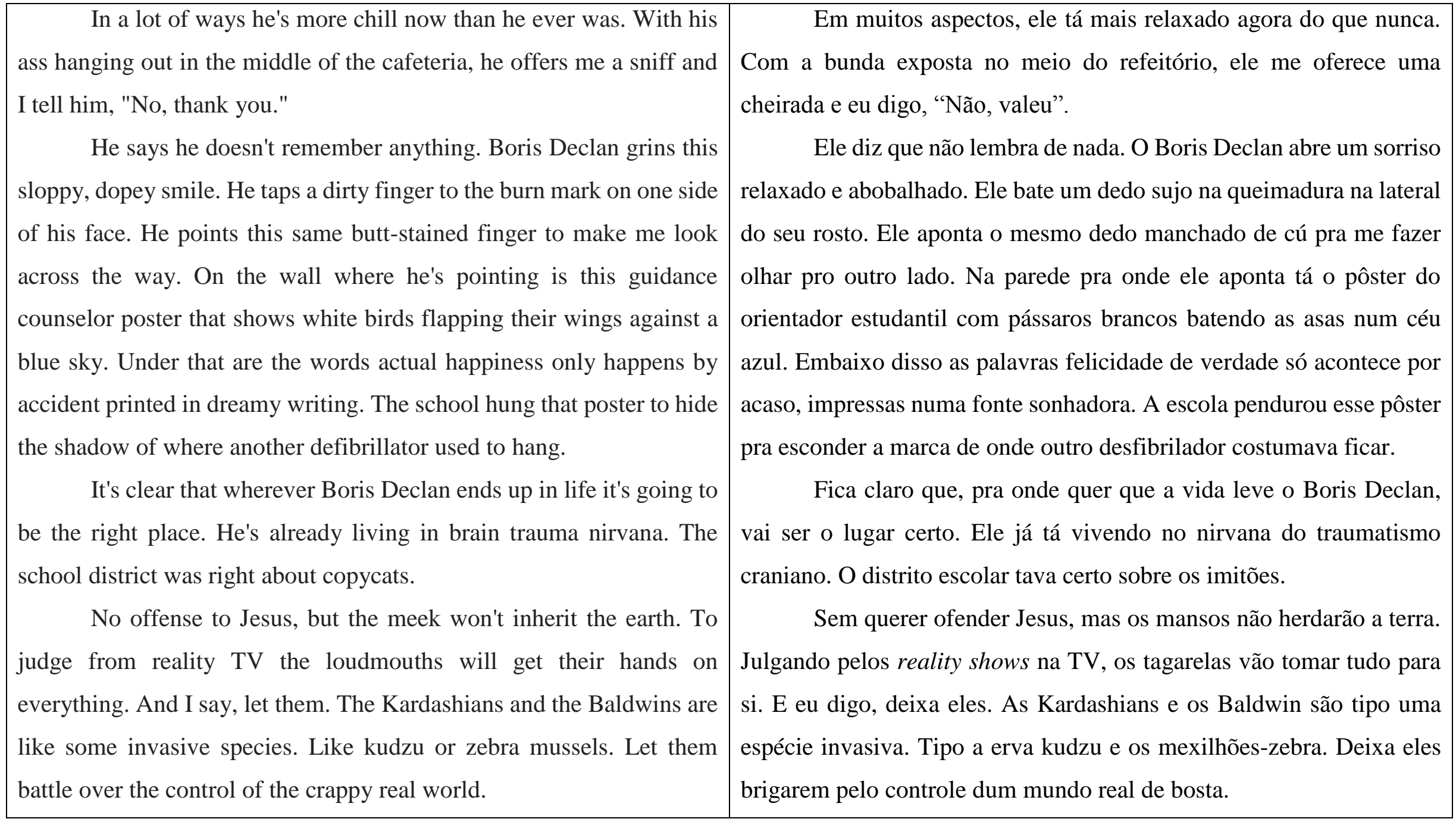


For a long time I listened to my uncle and didn't jump. Anymore, I don't know. The newspaper warns us about terrorist anthrax bombs and virulent new strains of meningitis, and the only comfort newspapers can offer is a coupon for 20 cents off on underarm deodorant.

To have no worries, no regrets-it's pretty appealing. So many of the cool kids at my school have elected to self-fry that, anymore, only the losers are left. The losers and the naturally occurring pinheads. The situation is so dire that I'm a shoo-in to be valedictorian. That's how come my uncle Henry is shipping me off. He thinks that by relocating me to Twin Falls he can postpone the inevitable.

So we're sitting at the airport, waiting by the gate for our flight to board, and I ask to go to the bathroom. In the men's room I pretend to wash my hands so I can look in the mirror. My uncle asked me, one time, why I looked in mirrors so much, and I told him it wasn't vanity so much as it was nostalgia. Every mirror shows me what little is left of my parents.

I'm practicing my mom's smile. People don't practice their smiles nearly enough, so when they most need to look happy they're
Por um tempão eu escutei meu tio e não pulei. Agora, eu já não sei mais. Os jornais advertem a gente quanto a bombas de antraz e novos casos virulentos de meningite e o único consolo que são capazes oferecer é um cupom de vinte centavos de desconto pra desodorantes.

Não ter preocupações nem arrependimentos — é bem atraente. Tanta gente descolada da minha escola já decidiu se autofritar que agora só sobraram os zé ruelas. Os zé ruelas e os que já nasceram retardados. A situação é tão feia que com certeza eu vou ser o orador da turma. É por causa disso que meu tio Henry tá me mandando embora. Ele acha que me transferindo pra Twin Falls, em Idaho, pode adiar o inevitável.

E então a gente tá sentado no aeroporto, esperando perto do portão o embarque do nosso voo começar e eu peço pra ir no banheiro. No banheiro masculino, finjo que tô lavando as mãos pra poder me olhar no espelho. Meu tio me perguntou, uma vez, por que que eu olho tanto no espelho e respondi que não era bem vaidade, mas nostalgia. Cada espelho me mostra o pouco do que sobrou dos meus pais.

Eu tô praticando o sorriso da minha mãe. As pessoas não praticam o sorriso tanto quanto deviam, daí quando elas mais precisam 
not fooling anyone. I'm rehearsing my smile when-there it is: my ticket to a gloriously happy future working in fast food. That's opposed to a miserable life as a world-famous architect or heart surgeon.

Hovering over my shoulder and a smidgen behind me, it's reflected in the mirror. Like the bubble containing my thoughts in a comic-strip panel, there's a cardiac defibrillator. It's mounted on the wall in back of me, shut inside a metal case with a glass door you could open to set off alarm bells and a red strobe light. A sign above the box says AED and shows a lightning bolt striking a Valentine's heart. The metal case is like the hands-off showcase holding some crown jewels in a Hollywood heist movie.

Opening the case, automatically I set off the alarm and flashing red light. Quick, before any heroes come running, I dash into a handicapped stall with the defibrillator. Sitting on the toilet, I pry it open. The instructions are printed on the lid in English, Spanish, French and comic-book pictures. Making it foolproof, more or less. If I wait too long I won't have this option. Defibrillators will be under lock and parecer que tão felizes da vida não conseguem enganar ninguém. Tô ali ensaiando meu sorriso quando - ali está: minha passagem prum futuro feliz e glorioso trabalhando numa rede de fast food. Isso ao invés duma vida miserável sendo um arquiteto ou cirurgião cardíaco famoso no mundo inteiro.

Pairando em cima do meu ombro e um pouquinho atrás de mim, ele se reflete no espelho. Como se fosse o balão com os meus pensamentos numa tira de quadrinhos, eis o desfibrilador cardíaco. Ele tá instalado na parede atrás de mim, fechado numa caixa de metal com uma porta de vidro que cê pode abrir se quiser disparar o alarme e uma luz estroboscópica vermelha. Tem um aviso em cima da caixa escrito DEA com um raio acertando um coração de dia dos namorados. A caixa de metal é que nem uma vitrine automatizada protegendo as joias da coroa num filme de roubo de Hollywood.

Quando eu abro a caixa, disparo na hora o alarme e a luz vermelha que pisca. Rapidão, antes que qualquer herói venha correndo, entro numa cabine de deficientes com o desfibrilador. Sentado na privada, destravo a alavanca e abro. As instruções tão impressas na tampa em inglês, espanhol, francês e imagens em quadrinhos. Isso meio que torna a parada à prova de idiotas. Se eu esperar demais, não vou ter 
key soon, and once defibrillators are illegal only paramedics will have them.

In my grasp, here's my permanent childhood. My very own bliss machine.

My hands are smarter than the rest of me. My fingers know to peel the electrodes and paste them to my temples. My ears know to listen for the loud beep that means the thing is fully charged.

My thumbs know what's best for me. They hover over the big red button. Like this is a video game. Like the button the president gets to press to trigger the launch of nuclear war. One push and the world as I know it comes to an end. A new reality begins.

To be or not to be. God's gift to animals is they don't get a choice.

Every time I open the newspaper I want to throw up. In another 10 seconds I won't know how to read. Better yet, I won't have to. I won't know about global climate change. I won't know about cancer or genocide or SARS or environmental degradation or religious conflict. mais essa essa opção. Os desfibriladores vão ser trancados a cadeado logo mais e, assim que se tornarem ilegais, só os paramédicos vão poder ter.

Eu tô segurando minha infância permanente. Minha própria máquina da felicidade.

Minhas mãos são mais espertas que o restante de mim. Meus dedos sabem como tirar o papel dos eletrodos e grudar nas minhas têmporas. Meus ouvidos sabem reconhecer o bipe alto que diz que a coisa tá totalmente carregada.

Meus polegares sabem o que é melhor pra mim. Eles pairam em cima do botão vermelho. Como se isso fosse um videogame. Como se fosse o botão que o presidente aperta pra começar uma guerra nuclear. Um toque e o mundo que eu conheço acaba. Uma nova realidade começa.

Ser ou não ser. O presente de Deus pros animais é que eles não têm escolha.

Cada vez que abro o jornal, eu quero vomitar. Daqui a dez segundos, não vou mais saber ler. Melhor ainda, não vou mais precisar ler. Não vou saber sobre mudanças climáticas. Não vou saber nada 


\begin{tabular}{|c|c|}
\hline & $\begin{array}{l}\text { sobre câncer ou genocídio ou pneumonia asiática ou degradação } \\
\text { ambiental ou conflito religioso }\end{array}$ \\
\hline $\begin{array}{l}\text { The public address system is paging my name. I won't even } \\
\text { know my name. }\end{array}$ & $\begin{array}{l}\text { O sistema de comunicação central tá bipando meu nome. Eu } \\
\text { nem vou saber meu nome. }\end{array}$ \\
\hline $\begin{array}{l}\text { Before I can blast off, I picture my uncle Henry at the gate, } \\
\text { holding his boarding pass. He deserves better than this. He needs to } \\
\text { know this is not his fault. }\end{array}$ & $\begin{array}{l}\text { Antes de me explodir, imagino meu tio Henry no portão de } \\
\text { embarque, segurando sua passagem. Ele merece mais que isso. Ele } \\
\text { precisa saber que não foi culpa dele. }\end{array}$ \\
\hline $\begin{array}{l}\text { With the electrodes stuck to my forehead, I carry the } \\
\text { defibrillator out of the bathroom and walk down the concourse toward } \\
\text { the gate. The coiling electric wires trail down the sides of my face like } \\
\text { thin, white pigtails. My hands carry the battery pack in front of me like } \\
\text { a suicide bomber who's only going to blow up all my IQ points. }\end{array}$ & $\begin{array}{l}\text { Com os eletrodos colados na testa, eu carrego o desfibrilador } \\
\text { pra fora do banheiro e vou andando pelo saguão em direção ao portão. } \\
\text { Os fios elétricos espiralados tão pendurados nas laterais do meu rosto } \\
\text { que nem rabinhos de porco finos e brancos. Minhas mãos seguram a } \\
\text { caixa da bateria na frente do meu corpo tipo um homem-bomba que só } \\
\text { vai explodir todos os meus pontos de QI. }\end{array}$ \\
\hline $\begin{array}{l}\text { When they catch sight of me, businesspeople abandon their } \\
\text { roller bags. People on family vacations, they flap their arms, wide, and } \\
\text { herd their little kids in the other direction. Some guy thinks he's a hero. } \\
\text { He shouts, "Everything is going to be all right." He tells me, "You have } \\
\text { everything to live for." }\end{array}$ & $\begin{array}{l}\text { Quando me veem, os executivos abandonam suas malas de } \\
\text { rodinha. As pessoas em férias de família abanam os braços pra todos os } \\
\text { lados e enxotam as crianças pra outra direção. Algum cara acha que é } \\
\text { herói. Ele grita, "Vai dar tudo certo". Ele me diz, "Você tem todos os } \\
\text { motivos para viver". }\end{array}$ \\
\hline & bemos que ele tá mentindo. \\
\hline
\end{tabular}




\begin{tabular}{|c|c|}
\hline My face is sweating so hard the electrodes might slip off. Here's & Meu rosto tá suando tanto que os eletrodos podem escorregar. \\
\hline my last chance to say everything that's on my mind, so with everyone & Essa é minha última chance de dizer tudo que eu penso, então, com \\
\hline watching I'll confess: I don't know what's a happy ending. And I don't & todo mundo assistindo, vou confessar: eu não sei o que é um final feliz. \\
\hline know how to fix anything. Doors open in the concourse and Homeland & E eu não sei como consertar nada. As portas do saguão se abrem e \\
\hline Security soldiers storm out, and I feel like one of those Buddhist monks & soldados do Departamento de Segurança Nacional vêm correndo e eu \\
\hline in Tibet or wherever who splash on gasoline before they check to make & me sinto tipo um daqueles monges budistas do Tibete ou sei lá onde \\
\hline sure their cigarette lighter actually works. How embarrassing that & que se encharcam de gasolina antes $\mathrm{c}$ \\
\hline would be, to be soaking in gasoline and have to bum a match off some & funcionam mesmo. Imagina que constrangedor deve ser, cê tá \\
\hline stranger, especially since so few people smoke anymore. Me, in the & de gasolina e tem que implorar um fósforo prum estranho, ainda mais \\
\hline middle of the airport concourse, I'm dripping with sweat instead of & agora que tão pouca gente fuma. Eu, no meio do saguão do aeroporto, \\
\hline gasoline, but this is how out of control my the & tô pingando suor ao i \\
\hline & perisantertus \\
\hline From out of nowhere my uncle grabs my arm, and he says, "If & Do nada, meu tio agarra meu braço e diz, "Se você se machucar, \\
\hline you hurt yours & Trevor, vai me machuce \\
\hline He's gripp & segurando meu braço e eu tô segurando o botão vermelho. \\
\hline $\begin{array}{l}\text { this isn't so tragic. I say, "I'll keep loving you, Uncle Henry...I just } \\
\text { won't know who you are." }\end{array}$ & $\begin{array}{l}\text { Digo pra ele que não é assim tão trágico. Eu digo, "Vou continuar te } \\
\text { amando, tio Henry... Só não vou saber quem você é". }\end{array}$ \\
\hline Inside my head, my last thoughts are prayers. I'm praying that & Dentro da minha cabeça, meus últimos pensamentos são \\
\hline this battery is fully charged. There's gc & orações. Rezo pra que essa bateria esteja cem por cento carregada. Tem \\
\hline e fact that I've just said the word $l c$ & \\
\hline
\end{tabular}


strangers. Even worse, I've said it to my own uncle. I'll never be able to

live that down.

Most people, instead of saving me, they pull out their telephones and start shooting video. Everyone's jockeying for the best full-on angle. It reminds me of something. It reminds me of birthday parties and Christmas. A thousand memories crash over me for the last time, and that's something else I hadn't anticipated. I don't mind losing my education. I don't mind forgetting my name. But I will miss the little bit I can remember about my parents.

My mother's eyes and my father's nose and forehead, they're dead except for in my face. And the idea hurts, to know that I won't recognize them anymore. Once I punch out, I'll think my reflection is nothing except me.

My uncle Henry repeats, "If you hurt yourself, you hurt me too."

I say, "I'll still be your nephew, but I just won't know it."

For no reason, some lady steps up and grabs my uncle Henry's other arm. This new person, she says, "If you hurt yourself, you hurt me as well..." Somebody else grabs that lady, and somebody grabs the palavra "amor" na frente de várias centenas de estranhos. Pior ainda, disse pro meu próprio tio. Nunca vou conseguir superar isso.

A maioria das pessoas, ao invés de me salvar, pega o celular e começa a filmar. Tá todo mundo competindo pelo melhor ângulo frontal. Isso me lembra alguma coisa. Isso me lembra festas de aniversário e Natal. Mil memórias me invadem pela última vez e isso é outra coisa que eu não tinha previsto. Eu não me importo de esquecer o que aprendi. Não me importo de esquecer meu nome. Mas vou sentir falta do pouquinho dos meus pais que consigo me lembrar.

Os olhos da minha mãe e o nariz e testa do meu pai, eles tão mortos, a não ser no meu rosto. E a ideia machuca, saber que eu não vou mais reconhecer eles. Depois que eu apertar o botão, eu vou pensar que meu reflexo não é nada além de mim.

Meu tio Henry repete, "Se você se machucar, vai me machucar também".

Eu digo, "Eu ainda vou ser seu sobrinho, só não vou saber disso".

Sem motivo algum, uma mulher aleatória avança e agarra o outro braço do meu tio. Essa pessoa, ela diz, "Se você se machucar, vai me machucar também..." Outra pessoa agarra a mulher, e mais outra 


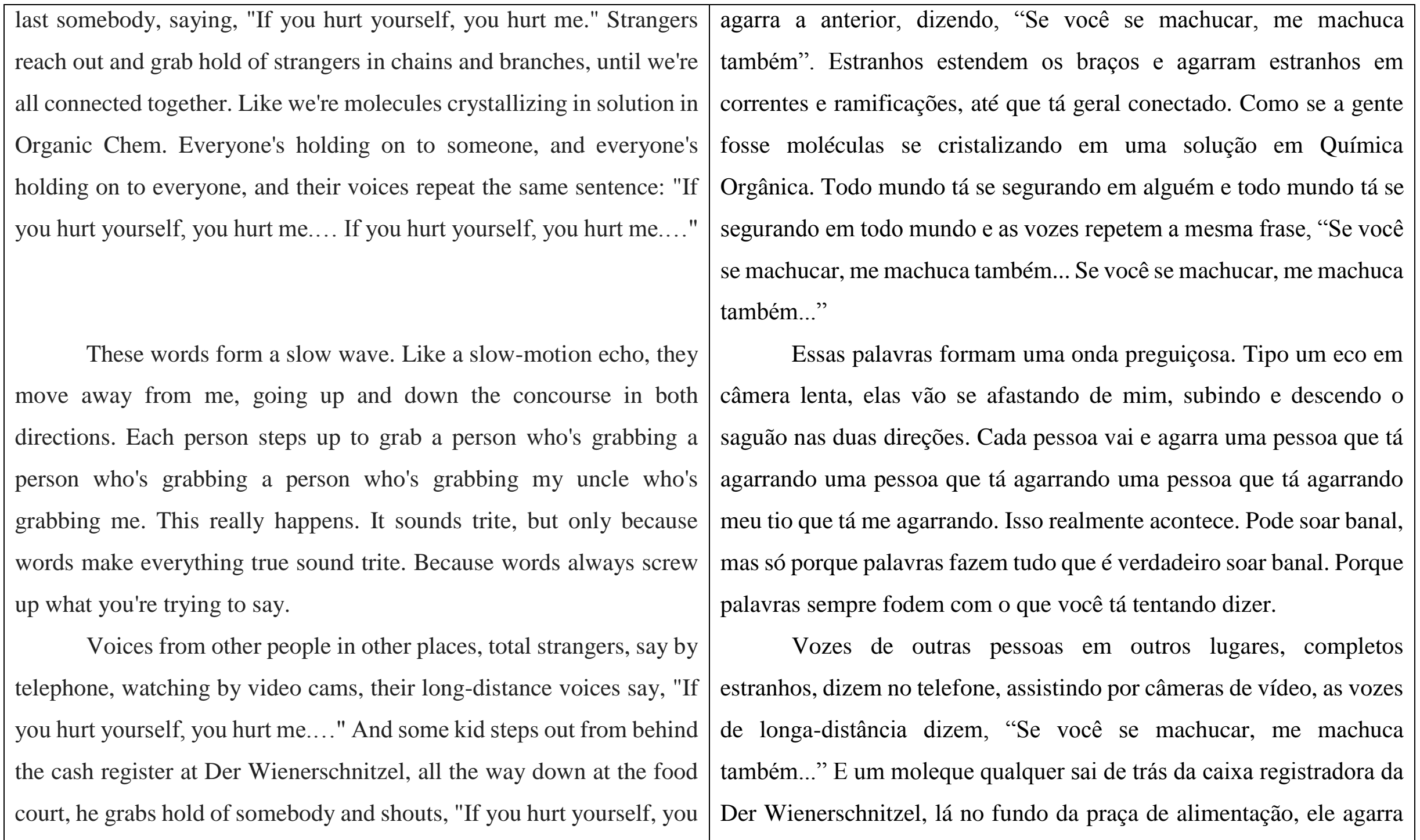




\begin{tabular}{|c|c|}
\hline $\begin{array}{l}\text { lk at } \\
\text { eone } \\
\text { just } \\
\text { way, } \\
\text { oing } \\
\text { king } \\
\text { the } \\
\text { and } \\
\text { ding } \\
\text { hurt } \\
\text { ts on }\end{array}$ & $\begin{array}{l}\text { alguém e grita, "Se cê se machucar, me machuca também". E os jovens } \\
\text { cozinhando no Taco Bell e os outros espumando leite na Starbucks, eles } \\
\text { param, e todos eles seguram na mão de alguém conectado a mim por } \\
\text { toda essa multidão, e eles dizem isso também. E bem quando eu penso } \\
\text { que isso tem que acabar e todo mundo tem que deixar isso de lado e se } \\
\text { mandar, porque tudo parou e as pessoas tão de mãos dadas, até pra } \\
\text { passar pelos detectores de metal elas tão de mãos dadas, mesmo aí o } \\
\text { âncora de notícias ao vivo da CNN, na televisão montada perto do teto, } \\
\text { o apresentador põe um dedo no ouvido, tipo pra ouvir melhor, e até } \\
\text { mesmo ele diz, "Últimas notícias". Ele parece confuso, claramente } \\
\text { lendo a informação de fichas de anotação e ele diz, "Se você se } \\
\text { machucar, me machuca também". E por cima da voz dele tão as vozes } \\
\text { dos especialistas políticos na Fox News e dos comentaristas esportivos } \\
\text { na ESPN e todos eles tão dizendo isto. } \\
\text { A televisão mostra gente do lado de fora em estacionamentos e } \\
\text { áreas com placas de proibido estacionar, todo mundo de mãos dadas. } \\
\text { Criando vínculos. Todo mundo tá mandando um vídeo para todo } \\
\text { mundo, pessoas a milhas de distância e mesmo assim conectadas a } \\
\text { mim. }\end{array}$ \\
\hline
\end{tabular}




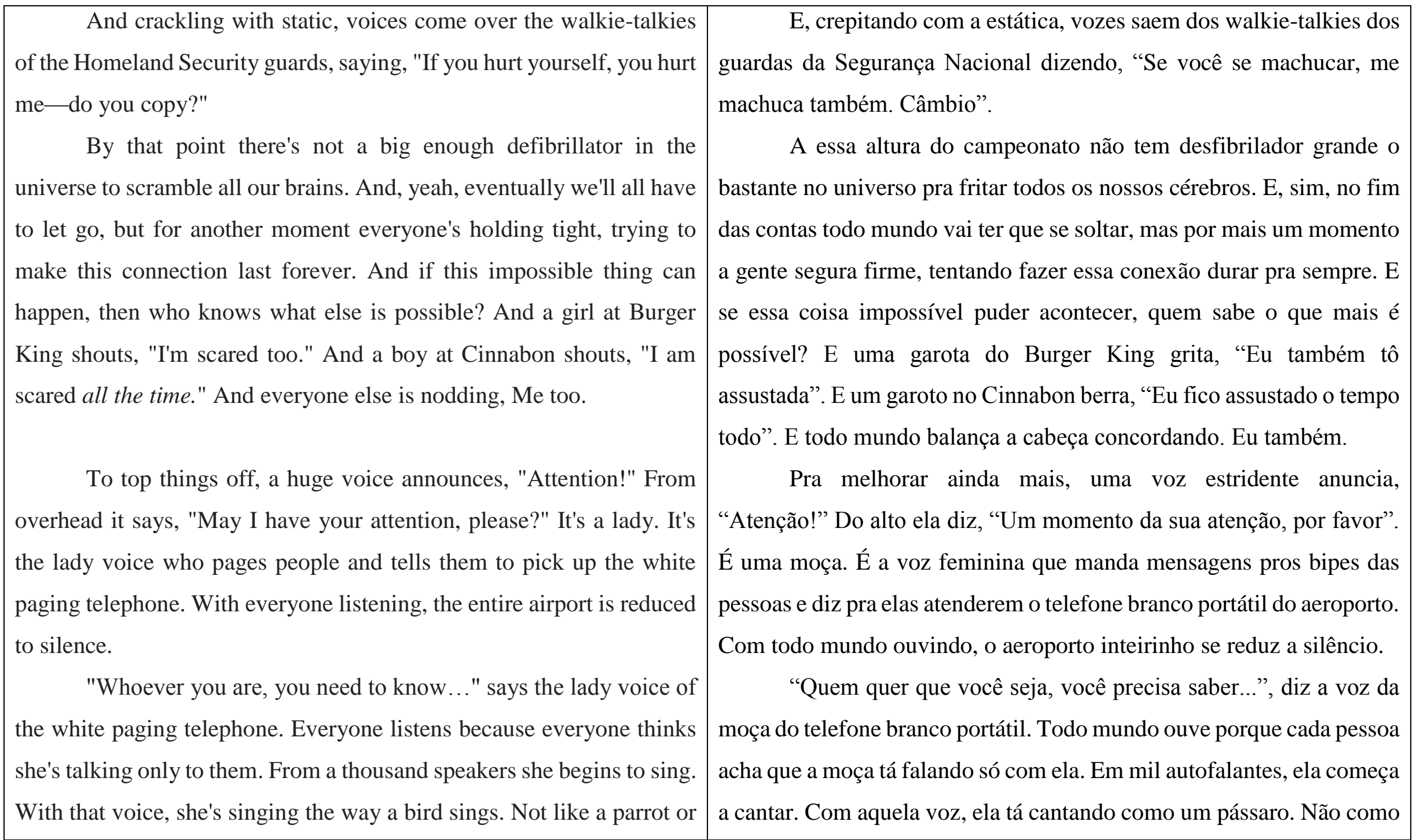


an Edgar Allan Poe bird that speaks English. The sound is trills and scales the way a canary sings, notes too impossible for a mouth to conjugate into nouns and verbs. We can enjoy it without understanding it. And we can love it without knowing what it means. Connected by telephone and television, it's synchronizing everyone, worldwide. That voice so perfect, it's just singing down on us.

Best of all...her voice fills everywhere, leaving no room for being scared. Her song makes all our ears into one ear.

This isn't exactly the end. On every TV is me, sweating so hard an electrode slowly slides down one side of my face.

This certainly isn't the happy ending I had in mind, but compared to where this story began-with Griffin Wilson in the nurse's office putting his wallet between his teeth like a gun-well, maybe this is not such a bad place to start. um papagaio ou um pássaro do Edgar Allan Poe que fala inglês. O som

é vibrante e cresce como o canto de um canário, notas impossíveis pruma boca conjugar em substantivos e verbos. Nós podemos apreciar sem compreender. E podemos amar sem saber o que ele significa. Conectados por telefones e televisão, tá sincronizando todo mundo, no mundo inteiro. Aquela voz tão perfeita, simplesmente entra na gente enquanto canta.

O melhor de tudo... a voz dela preenche todos os lugares, sem deixar espaço pro medo. A canção transforma todos os ouvidos em um ouvido só.

Esse não é bem o fim. Em cada TV tô eu, suando tanto que um eletrodo vai descendo devagar por um lado do meu rosto.

Com certeza esse não é o final feliz que eu tinha em mente, mas comparado com o ponto em que a história começou — com o Griffin Wilson na enfermaria colocando a carteira entre os dentes como uma arma — , bem, talvez não seja um início assim tão ruim. 


\section{ANEXO D}

\section{"Loser"}

The show still looks exactly like when you were sick with a really high fever and you stayed home to watch TV all day. It's not Let's Make a Deal. It's not Wheel of Fortune. It's not Monty Hall, or the show with Pat Sajak. It's that other show where the big, loud voice calls your name in the audience, says to "Come on down, you're the next contestant," and if you guess the cost of Rice-A-Roni then you fly round-trip to live for a week in Paris.

It's that show. The prize is never anything useful, like okay clothes or music or beer. The prize is always some vacuum cleaner or a washing machine, something you might maybe get excited to win if you were, like, somebody's wife.

It's Rush Week, and the tradition is everybody pledging Zeta Delt all take this big chartered school bus and need to go to some TV studio and watch them tape this game show. Rules say, all the Zeta Delts wear the same red T-shirt with printed on it the Greek Zeta Delta Omega deals, silk-screened in black. First, you need to take a little

\section{"Perdedor"}

O programa ainda tem a mesmíssima cara de quando cê tava doente ardendo de febre e ficou em casa pra ver TV o dia inteiro. Não é o Topa ou não Topa. Não é o Roda a Roda. Não é o Monty Hall, nem aquele programa com o Pat Sajak. É aquele outro programa com um vozeirão que chama seu nome na plateia, diz "Desce aqui, você é o próximo participante", e se cê acertar o preço duma caixa de arroz instantâneo da Rice-A-Roni, voa com tudo pago pra passar uma semana em Paris.

É aquele programa. O prêmio nunca é uma coisa útil, tipo umas roupas ou música ou cerveja. O prêmio é sempre um aspirador de pó ou uma máquina de lavar, alguma coisa que cê talvez ficasse feliz de ganhar se fosse, tipo, a esposa de alguém.

É a Semana de Recrutamento das fraternidades e é tradição a galera que tá tentando entrar pra Zeta Delta fretar esse busão escolar e ir num estúdio de TV onde eles gravam esses game shows. Pelas regras, todo Zeta Delta usa a mesma camiseta vermelha com as letras gregas Zeta Delta Ômega impressas, serigrafadas de preto. Primeiro, cê tem 
stamp of Hello Kitty, maybe half a stamp and wait for the flash. It's like this little paper stamp printed with Hello Kitty you suck on and swallow, except it's really blotter acid.

All you do is, the Zeta Delts sit together to make this red patch in the middle of the studio audience and scream and yell to get on TV. These are not the Gamma Grab'a Thighs. They're not the Lambda Rape'a Dates. The Zeta Delts, they're who everybody wants to be.

How the acid will affect you - if you're going to freak out and kill yourself or eat somebody alive - they don't even tell you.

\section{It's traditional.}

Ever since you were a little kid with a fever, the contestants they call down to play this game show, the big voice always calls for one guy who's a United States Marine wearing some band uniform with brass buttons. There's always somebody's old grandma wearing a sweatshirt. There's an immigrant from some place where you can't understand half of what he says. There's always some rocket scientist with a big belly and his shirt pocket stuck full of pens.

It's just how you remember it, growing up, only now-all the Zeta Delts start yelling at you. Yelling so hard it scrunches their eyes que tomar esse selinho da Hello Kitty, talvez metade dum selo e esperar bater. É tipo um pedacinho de papel com estampa da Hello Kitty que cê chupa e engole, só que na verdade é LSD.

Tudo que rola é, os Zeta Deltas sentam juntos pra formar essa área vermelha no meio da plateia do estúdio e gritam e berram pra aparecer na TV. Eles não são os Gamas Mão-Boba. Não são os Lambdas Boa-Noite-Cinderela. Os Zeta Deltas são quem todo mundo quer ser.

Como o LSD vai te afetar - se cê vai enlouquecer e se matar ou comer alguém vivo - eles nem te dizem.

\section{É a tradição.}

Desde quando cê era uma criancinha com febre, os competidores que eles chamam pra participar do game show, o vozeirão sempre chama um cara da Marinha dos Estados Unidos vestindo um uniforme militar com botões de metal. Tem sempre a vovó idosa de alguém vestindo um moletom. Tem um imigrante de algum lugar onde cê num entende nem metade do que ele diz. Tem sempre um gênio da ciência barrigudo com o bolso da camisa cheio de canetas.

É igualzinho cê se lembra de quando era mais novo, só que agora - todos os Zeta Deltas começam a gritar contigo. Gritam tão alto 
shut. Everybody's just these red shirts and big-open mouths. All their hands are pushing you out from your seat, shoving you into the aisle. The big voice is saying your name, telling you to come on down. You're the next contestant.

In your mouth, the Hello Kitty tastes like pink bubblegum. It's the Hello Kitty, the popular kind, not the strawberry flavor or the chocolate flavor somebody's brother cooks at night in the General Sciences building where he works as a janitor. The paper stamp feels caught partway down your throat, except you don't want to gag on TV, not on recorded video with strangers watching, forever.

All the studio audience is turned around to see you stumble down the aisle in your red Tshirt. All the TV cameras, zoomed in. Everybody clapping exactly how you remember it. Those Las Vegas lights, flashing, outlining everything onstage. It's something new, but you've watched it done a million-zillion times before, and just by automatic you take the empty desk next to where the United States Marine is standing.

The game show host, who's not Alex Trebek, he waves one arm, and a whole part of the stage starts to move. It's not an earthquake, but one whole wall rolls on invisible wheels, all the lights everywhere que até fecham os olhos de tanta força. Todo mundo é só camisetas vermelhas e boconas abertas. Todas as mãos te forçam pra fora da cadeira, te empurrando pro corredor. O vozeirão tá dizendo seu nome, falando pra você descer. Cê é o próximo competidor.

Na sua boca, a Hello Kitty tem gosto de chiclete rosa. É a Hello Kitty, o tipo mais comum, não a sabor morango ou sabor chocolate que o irmão de alguém cozinha a noite no prédio de Ciências Gerais que ele trabalha de zelador. Parece que o selo de papel tá meio entalado na sua garganta, só que cê não quer engasgar na TV, não numa gravação com estranhos assistindo, pra sempre.

A plateia toda do estúdio tá virada pra ver você e sua camiseta vermelha descerem tropeçando pelo corredor. Todas as câmeras de TV, focadas. Todo mundo tá aplaudindo igual cê se lembra. Aquelas luzes de Las Vegas, piscando, deixam tudo no palco mais claro. É uma coisa nova, mas cê já viu isso acontecer um milhão-zilhão de vezes antes e no piloto automático cê pega a mesa vazia do lado do cara da Marinha dos Estados Unidos.

O apresentador do programa, que não é o Alex Trebek, acena com um braço e uma parte inteira do palco começa a se mover. Não é um terremoto, só que uma parede inteira gira numas rodas invisíveis, 


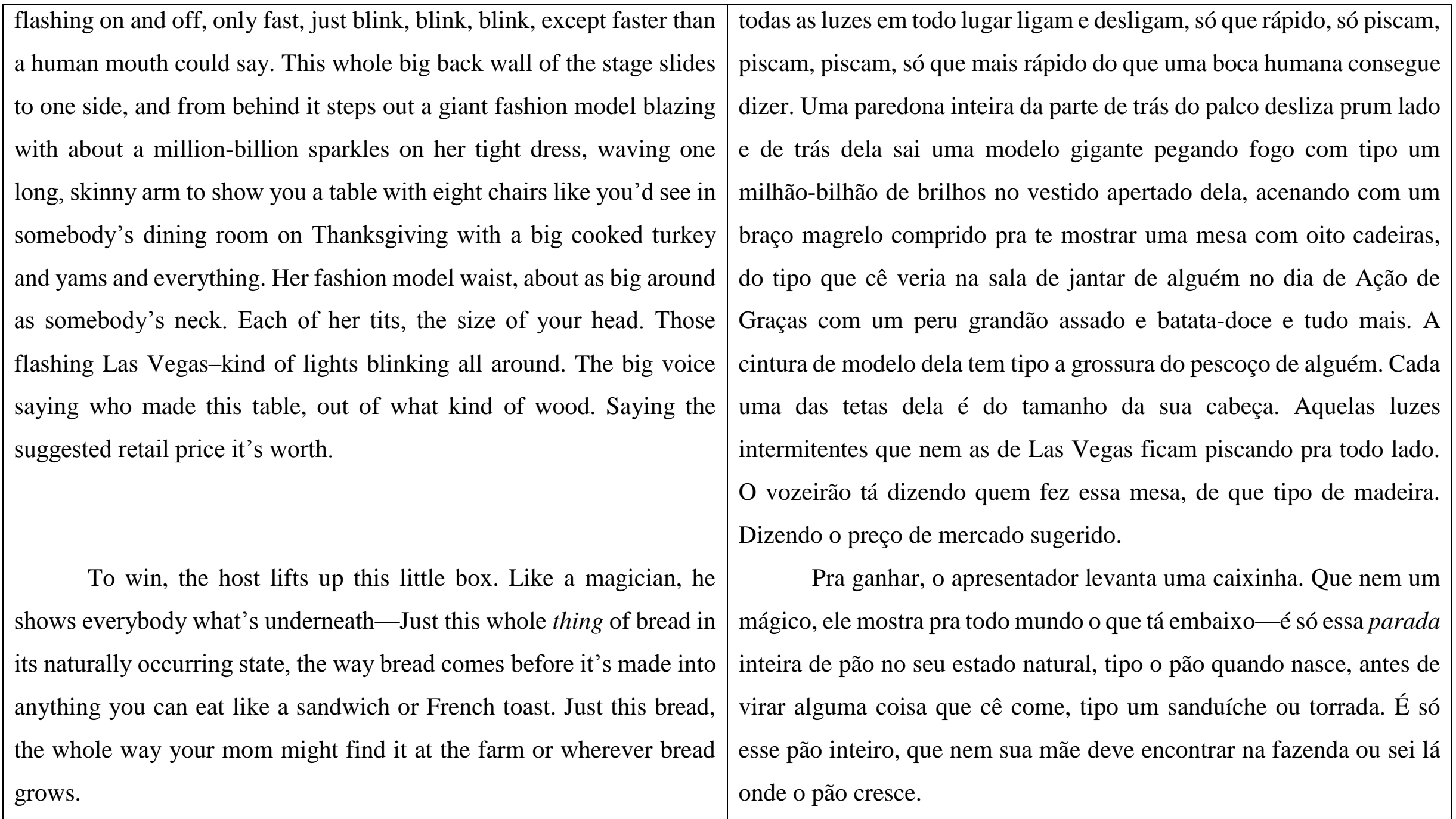


The table and chairs are totally, easy yours, except you have to guess the price of this big bread.

Behind you, all the Zeta Delts crowd really close together in their T-shirts, making what looks like one giant, red pucker in the middle of the studio audience. Not even looking at you, all their haircuts are just huddled up, making a big, hairy center. It's like forever later when your phone rings, and a Zeta Delt voice says what to bid.

That bread just sitting there the whole time. Covered in a brown crust. The big voice says it's loaded with ten essential vitamins and minerals.

The old game show host, he's looking at you like maybe he's never, ever seen a telephone before. He goes, "And what do you bid?"

\section{And you go, "Eight bucks?"}

From the look on the old grandma's face, it's like maybe they should call some paramedics for her heart attack. Dangling out one sweatshirt cuff, this crumpled scrap of Kleenex looks like leaked-out stuffing, flapping white, like she's some trashed teddy bear somebody loved too hard.
A mesa e as cadeiras são todas suas, fácil assim, só que cê tem que adivinhar o preço desse pãozão.

Atrás de você, todos os Zeta Deltas de camisetas vermelhas se amontoam bem perto e formam tipo um cú vermelho gigante no meio da plateia. Sem nem olhar pra você, esses cortes de cabelo todos se juntam e formam tipo um grande centro cabeludo. Parece que é uma eternidade depois quando seu celular toca e uma voz Zeta Delta te diz quanto chutar.

O pão tá lá parado o tempo todo. Coberto com uma casca marrom. O vozeirão diz que ele tem dez minerais e vitaminas essenciais.

O apresentador velho do game show, ele tá te olhando como se nunca tivesse visto um celular na vida. Ele diz, "E qual o seu lance?"

E você diz, "Oito dólares?”

Pela cara da vovó idosa, talvez seja melhor chamarem os paramédicos pra socorrer o ataque cardíaco dela. Num dos punhos do moletom tem um pedaço amassado de Kleenex parecendo um recheio que vazou, escorrendo branco como se ela fosse um ursinho de pelúcia rasgado que alguém amou com entusiasmo demais. 


\begin{tabular}{|c|c|}
\hline To cut you off using some brilliant strategy, the United States & Pra te tirar da jogada com alguma estratégia brilhante, o cara da \\
\hline Marine, the bastard, he says, "Nine dollars." & Marinha dos Estados Unidos, o escroto, ele diz: — Nove dólares. \\
\hline Then to cut him off, the rocket science guy says, "Ten. Ten & Depois, pra tirar o cara da jogada, o gênio da ciência diz: - \\
\hline dollars." & Dez. Dez dólares. \\
\hline It must be some trick ques & Isso deve ser uma pegadinha, porque a vovó diz, "Um dólar e \\
\hline "One dollar and ninety-nine cents," and all the music starts, loud, and & noventa e nove centavos", e a música começa, alta, e as luzes acendem \\
\hline the lights flash on and off. The host hauls the granny up onto the stage, & e apagam. O apresentador puxa a vovó pra cima do palco e ela tá \\
\hline and she's crying and plays a game where she throws a tennis ball to win & chorando e joga um jogo que ela arremessa um \\
\hline a sofa and a pool table. Her grandma face looks just as smashed and & ganhar um sofá e uma mesa de sinuca. A cara de vovó dela parece tão \\
\hline wrinkled as that Kleenex she pulls out from her swe & amassada e amarrotada quanto o Kleenex que ela puxa da manga do \\
\hline ther granny to take her place, and everything keeps & moletom. O vozeirão chama c \\
\hline rushing forward. & continua acontecendo rapidão. \\
\hline The next round, you need to guess the price of some potatoes, & Na rodada seguinte, cê tem que adivinhar o preço de batatas, \\
\hline but like a whole big thing of $r$ & mas é, tipo, uma parada grande de batatas de verdade, vivas, de antes \\
\hline become food, the way they come from the miners or whoever that dig & de virar comida, do jeito que elas vêm dos mineradores ou da galera lá \\
\hline potatoes in Ireland or Idaho or some other place starting with an "I." & que escava batatas na Irlanda ou Idaho ou algum outro lugar que \\
\hline Not even made into potato chips o & começa com "I". Nem viraram chips de batata ou batatas fritas ainda. \\
\hline If you guess right, you get some big clock inside a wood box & Se cê chutar certo, ganha um relógio grande dentro duma caixa \\
\hline like a Dracula coffin standing on o & de madeira que parece um caixão do Drácula de pé, só que com sinos \\
\hline bells inside the box that ding-ding & \\
\hline
\end{tabular}




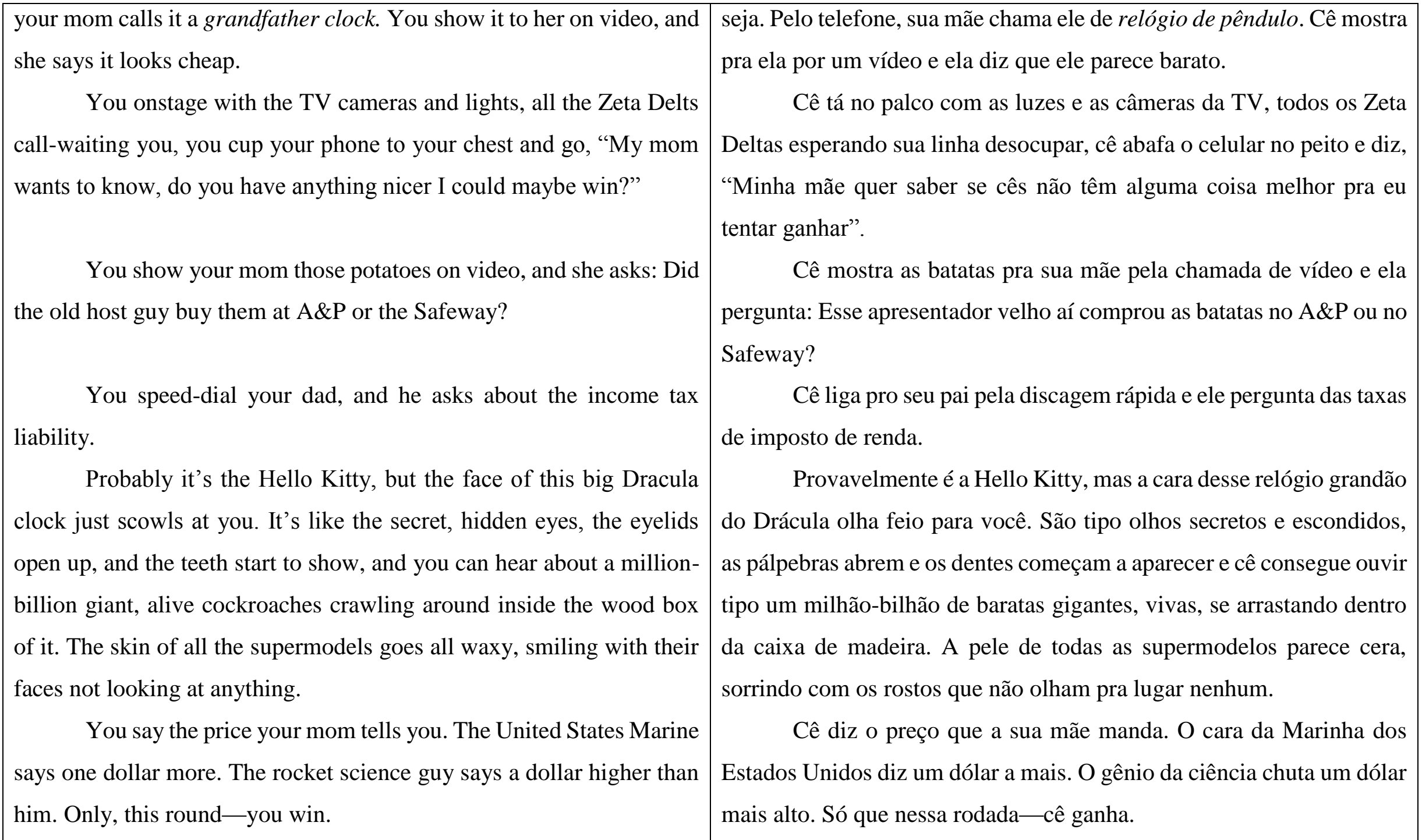




\begin{tabular}{|c|c|}
\hline All those potatoes open their little eyes. & Todas aquelas batatas abrem os olhinhos. \\
\hline Except now, you need to guess the price of a whole cow-full of & Só que agora cê tem que adivinhar o preço de uma caixa de leite \\
\hline milk in a box, the way milk comes in the kitchen fridge. You have to & do tamanho duma vaca, do jeito que o leite vem na geladeira da \\
\hline guess the cost of a whole thing of breakfast cereal like you'd find in the & cozinha. Cê tem que adivinhar o valor de uma coisa inteira de cereal de \\
\hline kitchen cabinet. After that, a giant deal of pure salt the way it comes & café da manhã, que nem cê encontra no armário da despensa. Depois \\
\hline from the ocean only in a round box, but more salt than anybody could & disso, um tantão enorme de sal que nem ele vem do oceano, só que \\
\hline $\begin{array}{l}\text { eat in an entire lifetime. Enough salt, you could rim approximately a } \\
\text { million-billion margaritas. }\end{array}$ & $\begin{array}{l}\text { numa caixa redonda, mas mais sal do que qualquer pessoa poderia } \\
\text { comer na vida inteira. Sal o bastante pra cobrir a borda de mais ou } \\
\text { menos um milhão-bilhão de margaritas. }\end{array}$ \\
\hline All the Zeta Delts start texting you like crazy. Your in-box & Todos os Zeta Deltas começam a te mandar mensagens feito \\
\hline piling up. & loucos. Sua caixa de entrada tá lotando. \\
\hline Next come these eggs like you'd find at Easter only pla & Depois vêm esses ovos, tipo os que cê vê na Páscoa, só que \\
\hline and lined up inside some special kind of cardboard case. A whole, & completamente brancos e alinhados dentro dum tipo especial de caixa \\
\hline complete set of twelve. These really minimalist eggs, pure white...so & de papelão. Um conjunto inteirinho de doze. Esses ovos tão \\
\hline white you could just look at them forever, only right away you need to & minimalistas, de um branco tão puro... tão brancos que cê poderia só \\
\hline guess at a big bottle like a yellow shampoo, except it's something gross & olhar pra eles pra sempre, só que agora cê precisa chutar o valor de uma \\
\hline called cooking oil, you don't know what for, and the next thing is you & garrafa grande tipo de um shampoo amarelo, mas que é uma coisa \\
\hline need to choose the right price of something frozen. & nojenta que eles chamam de óleo de cozinha que cê não sabe pra que \\
\hline & $\begin{array}{l}\text { serve, e depois cê tem que escolher o preço certo pra alguma coisa } \\
\text { congelada. }\end{array}$ \\
\hline
\end{tabular}


You cup one hand over your eyes to see past the footlights, except all the Zeta Delts are lost in the glare. All you can hear is their screaming different prices of money. Fifty thousand dollars. A million. Ten thousand. Just loony people yelling just numbers.

Like the TV studio is just some dark jungle, and people are just some monkeys just screeching their monkey sounds.

The molars inside your mouth, they're grinding together so hard you can taste the hot metal of your fillings, that silver melting in your back teeth. Meantime, the sweat stains creep down from your armpit to your elbow, all black-red down both sides of your Zeta Delt T-shirt. The flavor of melted silver and pink bubblegum. It's sleep apnea only in the day, and you need to remind yourself to take the next breath...take another breath...while the supermodels walking on sparkle high heels try pimping the audience a microwave oven, pimping a treadmill while you keep staring to decide if they're really goodlooking. They make you spin this doohickey so it rolls around. You have to match a bunch of different pictures so they go together perfect. Like you're some white rat in Principles of Behavioral Psychology 201, they make you guess what can of baked beans costs more than another.

All that fuss to win something you sit on to mow your lawn.
Cê cobre os olhos com as mãos pra enxergar além das luzes do palco, só que todos os Zelta Deltas tão ofuscados pelo clarão. A única coisa que cê ouve são eles gritando valores diferentes. Cinquenta mil dólares. Um milhão. Só gente doidona berrando números aleatórios.

Como se o estúdio de TV não passasse de uma selva sombria e as pessoas fossem só macacos guinchando macaquices.

Os molares dentro da sua boca, eles rangem com tanta força que cê pode sentir o gosto do metal quente das suas obturações, aquela prata derretendo nos seus dentes de trás. Enquanto isso, as manchas de suor vão escorrendo das suas axilas pros cotovelos, descendo pretoavermelhadas pelos dois lados da sua camiseta Zeta Delta. Com gosto de prata derretida e chiclete cor-de-rosa. É uma apneia do sono durante o dia e cê tem que se lembrar de respirar de novo... e de novo... enquanto as supermodelos desfilando com saltos brilhantes tentam vender pra plateia um forno de micro-ondas, tentam vender uma esteira enquanto cê continua encarando elas pra decidir se são bonitas mesmo. Elas te fazem girar esse bagulho pra ficar rodando pelo palco. Cê tem que combinar um monte de figuras diferentes para formar pares perfeitos. Como se cê fosse um rato branco em Princípios de Psicologia Comportamental 201, elas te fazem adivinhar qual lata de feijão cozido 


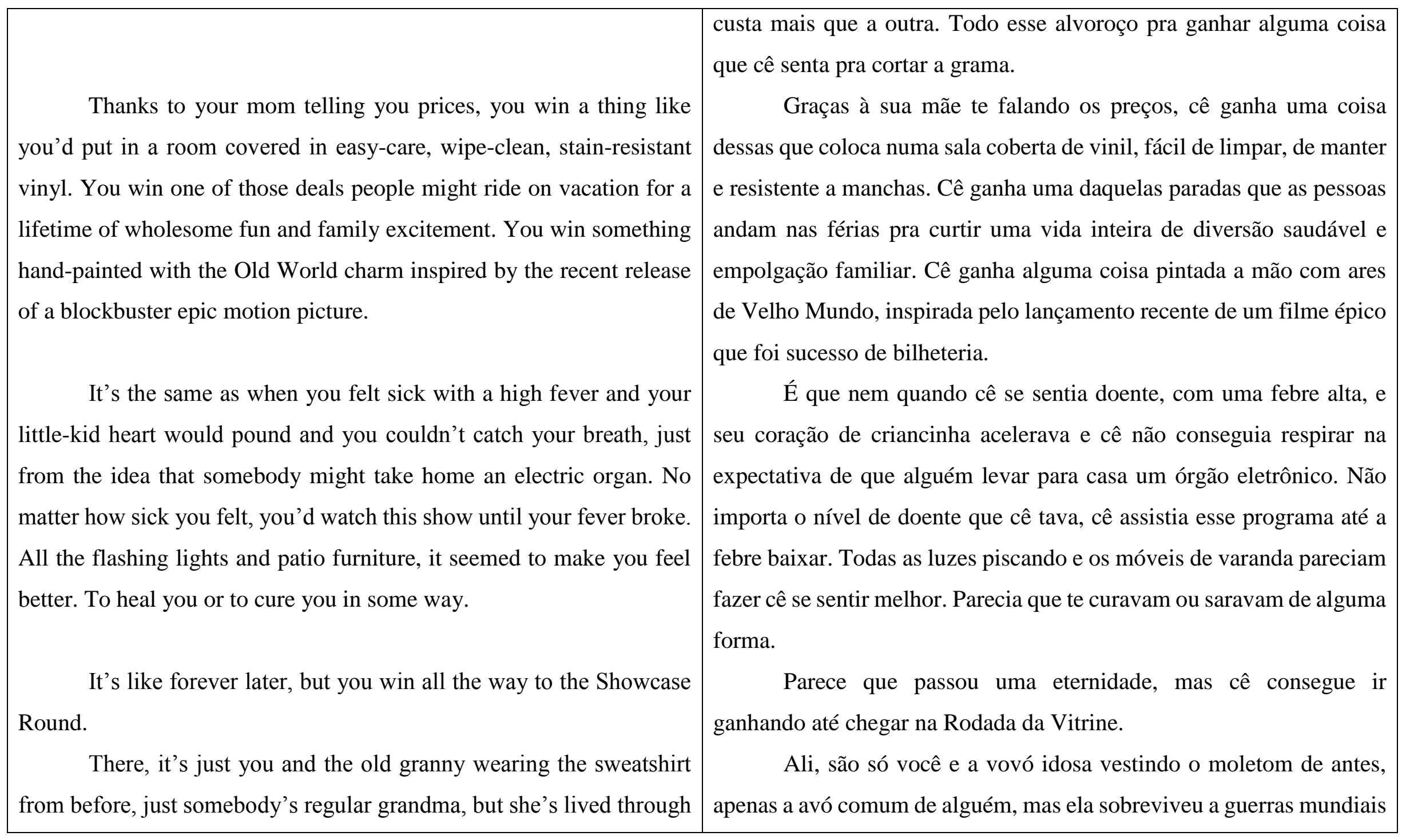




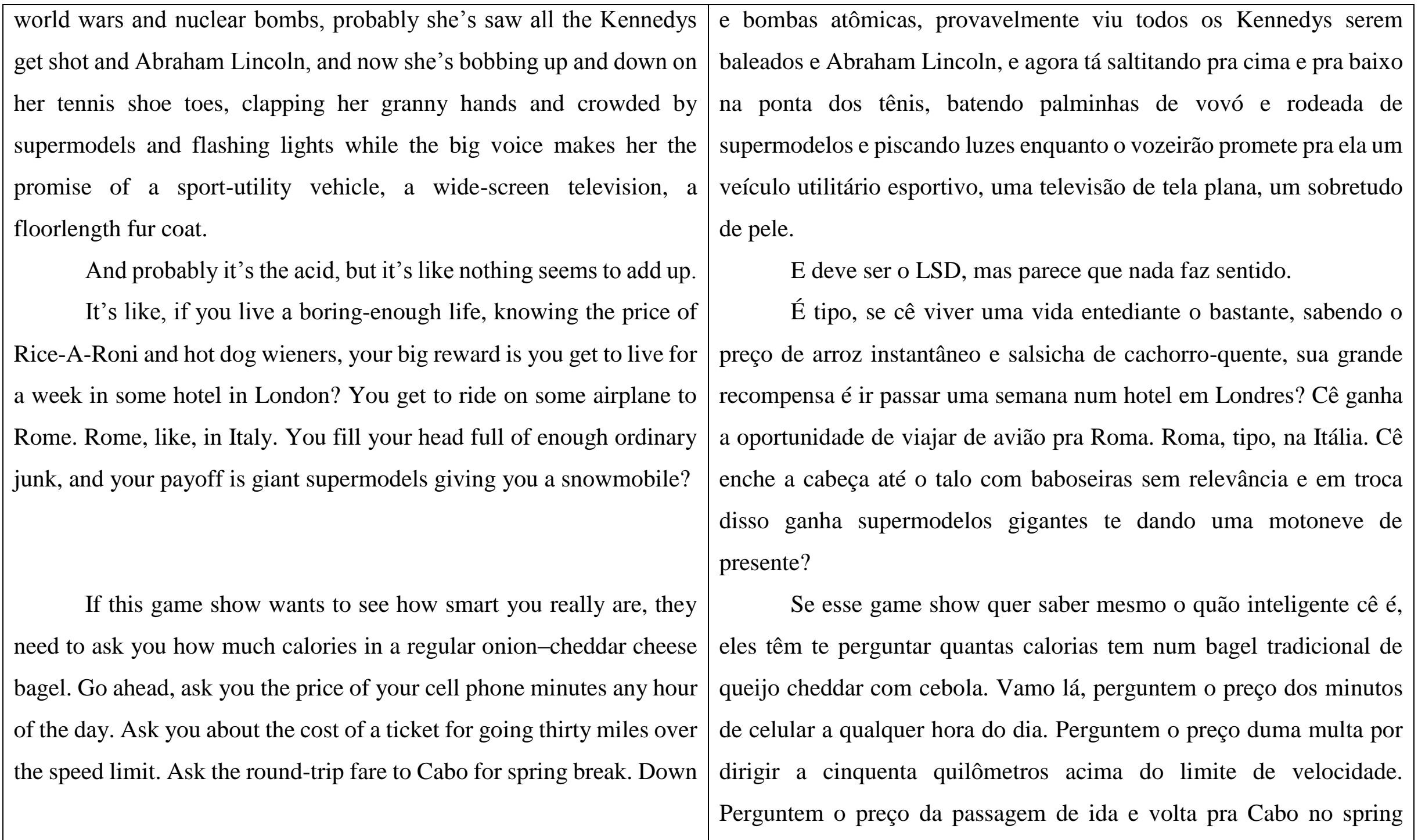


to the penny, you can tell them the price of decent seats for the Panic at the Disco! reunion tour.

They should ask you the price of a Long Island Iced Tea. The price of Marcia Sanders's abortion. Ask about your expensive herpes medication you have to take but don't want your folks to know you need. Ask the price of your History of European Art textbook which cost three hundred bucks_-fuck you very much.

Ask what that stamp of Hello Kitty set you back.

The sweatshirt granny bids some regular amount of money for her showcase. Just like always, the numbers of her bid appear in tiny lights, glowing on the front of her contestant desk where she stands.

Here, all the Zeta Delts are yelling. Your phone keeps ringing and ringing.

For your showcase, a supermodel rolls out five hundred pounds of raw beefsteak. The steaks fit inside a barbecue. The barbecue fits onboard a speedboat that fits inside a trailer for towing it that fits a massive fifthwheel pickup truck that fits inside the garage of a brandnew house in Austin. Austin, like, in Texas. break. Cê pode dizer até os centavos do valor de lugares decentes pra turnê de volta do Panic at the Disco!.

Eles deviam te perguntar o preço dum Long Island Iced Tea. O preço do aborto da Marcia Sanders. Perguntar o preço do remédio caro pra herpes que cê tem que tomar, mas não quer que seus pais saibam que você precisa. Perguntar o preço do seu livro teórico de História da Arte Europeia que custa trezentos dólares-obrigada de nada, seus bostas.

Perguntar o que aquele selo da Hello Kitty te fez perder.

A vovó de moletom chuta uma quantia qualquer de dinheiro pra vitrine dela. Como sempre, os números do lance dela aparecem numas luzes minúsculas, brilhando na frente da mesa de participante que ela tá.

Aqui, todos os Zeta Deltas tão gritando. Seu telefone continua tocando e tocando.

Pra sua vitrine, uma supermodelo traz duzentos e vinte quilos de bife cru. Os bifes cabem dentro duma churrasqueira. A churrasqueira cabe a bordo duma lancha que cabe dentro dum trailer de reboque que encaixa na quinta roda duma caminhonete enorme que cabe na garagem duma casa nova em folha em Austin. Austin, tipo, no Texas. 


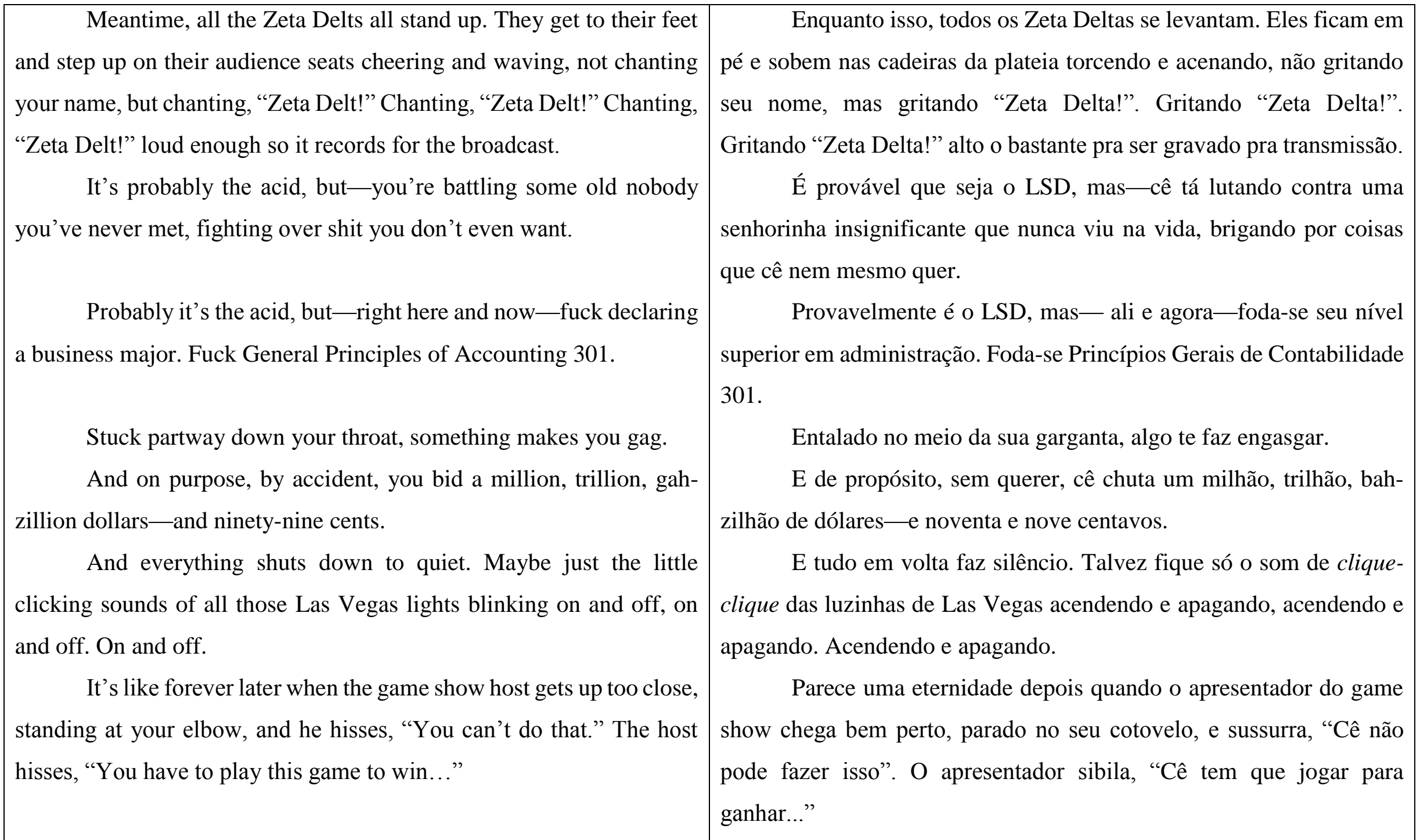




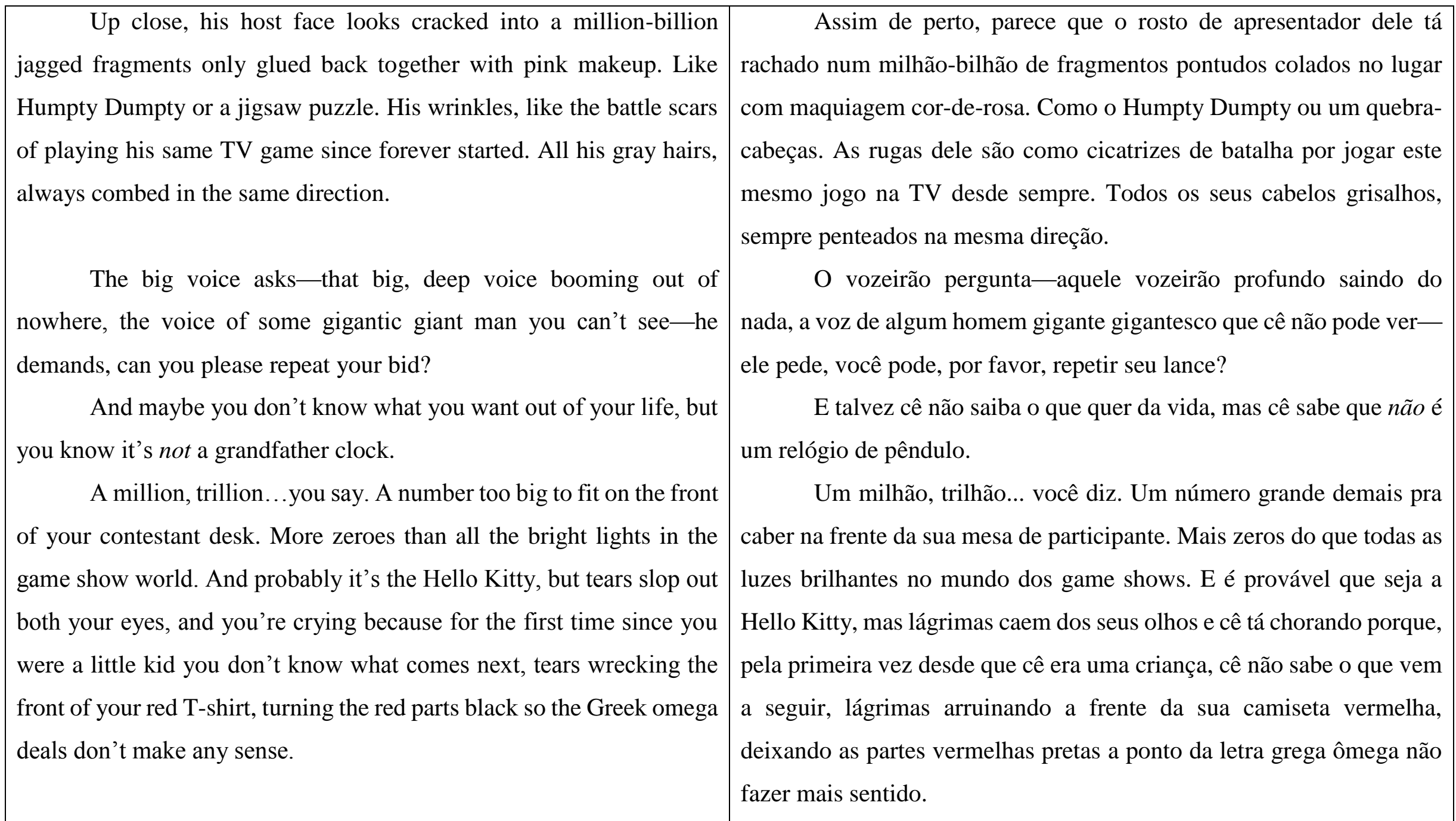


The voice of one Zeta Delt, alone in all that big quiet audience, somebody yells, "You suck!"

On the little screen of your phone, a text message says, "Asshole!"

The text? It's from your mom.

The sweatshirt grandma, she's crying because she won. You're sobbing because-you don't know why.

It turns out the granny wins the snowmobiles and the fur coat. She wins the speedboat and the beefsteaks. The table and chairs and sofa. All the prizes of both the showcases, because your bid was way, way too high. She's jumping around, her bright-white false teeth throwing smiles in every direction. The game show host gets everybody started clapping their hands, except the Zeta Delts don't. The family of the old granny climbs up onstage - all the kids and grandkids and greatgrandkids of her-and they wander over to touch the shiny sport utility vehicle, touch the supermodels. The granny plants red lipstick kisses all over the fractured pink face of the game show host. She's saying, “Thank you." Saying, "Thank you." Saying, "Thank you," right up to when her granny eyes roll up backward inside her head, and her hand grabs at the sweatshirt where it covers her heart.
A voz de um dos Zeta Deltas, sozinha naquela plateia grande e silenciosa, alguém grita: — Cê é um merda!

$\mathrm{Na}$ telinha do seu celular, uma mensagem de texto diz "Imbecil!".

A mensagem? É da sua mãe.

A vovó do moletom, ela tá chorando porque ganhou. Cê tá soluçando porque - cê não sabe porquê.

No fim das contas, a vovó ganha as motoneves e o casaco de pele. Ela ganha a lancha e os bifes. A mesa e as cadeiras e o sofá. Todos os prêmios das duas vitrines porque o seu lance foi alto demais da conta. Ela tá saltitando, os dentes falsos num branco brilhante sorriem pra todo lado. O apresentador do programa faz todo mundo começar a aplaudir, mas os Zeta Deltas não aplaudem. A família da vovó idosa sobe no palco - todos os filhos e netos e bisnetos dela-e correm pra tocar no veículo utilitário esportivo reluzente, tocar nas supermodelos. A vovó planta beijos de batom vermelho em toda a cara rosa retalhada do apresentador do game show. Ela tá dizendo "Brigada". Dizendo "Brigada". Dizendo "Brigada", até que olhos de vovó dela se viram pra dentro de cabeça e ela agarra o moletom bem onde ele cobre o coração. 
